\author{
UNIVERSIDADE DE SÃO PAULO \\ FACULDADE DE ZOOTECNIA E ENGENHARIA DE ALIMENTOS
}

MARLUCI PALAZZOLLI DA SILVA

Delivery systems for simultaneous intake of probiotics and plant extracts

Pirassununga 
MARLUCI PALAZZOLLI DA SILVA

Delivery systems for simultaneous intake of probiotics and plant extracts

Corrected Version

Doctoral thesis presented to the Faculdade de Zootecnia e Engenharia de Alimentos, Universidade de São Paulo for obtaining the title of Doctor in Science.

Concentration area: Sciences of Food Engineering

Advisor: Profa. Dra. Carmen Sílvia Fávaro Trindade

Pirassununga 
Ficha catalográfica elaborada pelo

Serviço de Biblioteca e Informação, FZEA/USP, com os dados fornecidos pelo(a) autor(a)

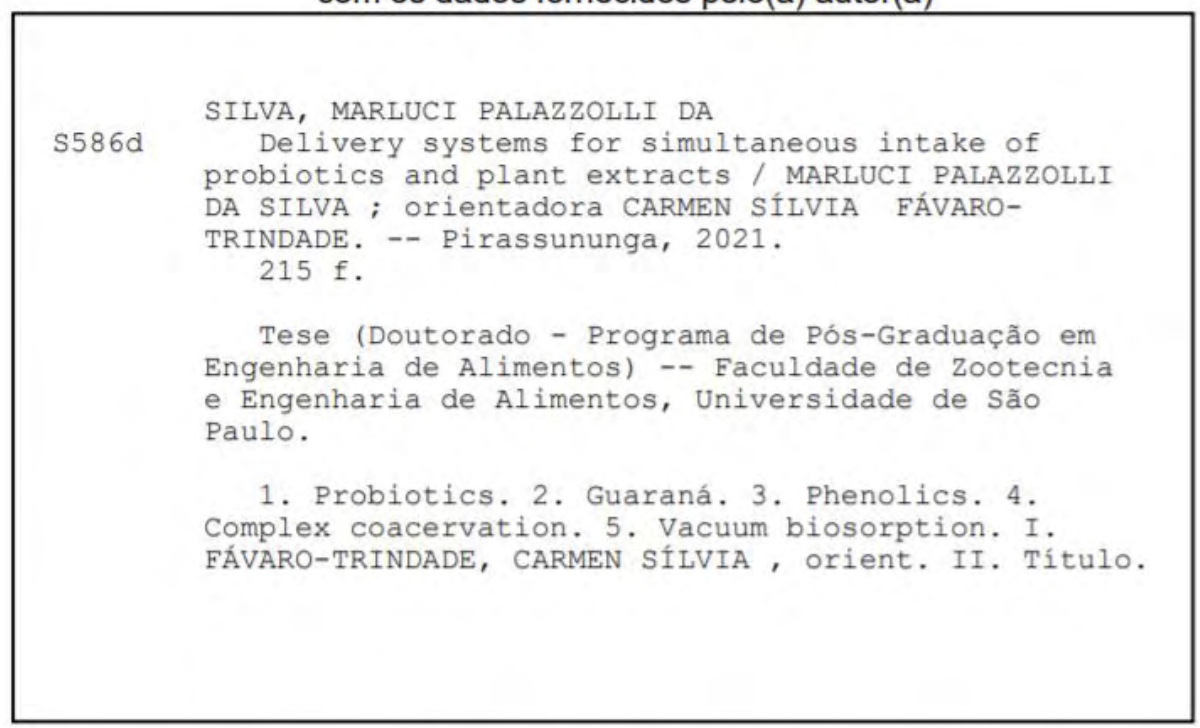

Permitida a cópia total ou parcial deste documento, desde que citada a fonte - o autor 
Delivery systems for simultaneous intake of probiotics and plant extracts

Doctoral thesis presented to the Faculdade de Zootecnia e Engenharia de Alimentos, Universidade de São Paulo for obtaining the title of Doctor in Science.

Approval date: $16 / 12$ / 2021

Exammining commission:

Prof. Dr. Carmen Sílvia Fávaro Trindade - President of Examining comission and advisor

Prof. Dr. Susana Marta Isay Saad

Universidade de São Paulo - USP

Prof. Dr. Milena Martelli Tosi

Universidade de São Paulo - USP

Prof. Dr. Líbia Diniz Santos

Universidade Federal de Uberlândia - UFU

Prof. Dr. Tatiana Colombo Pimentel

Instituto Federal do Paraná - IFPR

Prof. Dr. Rodrigo Rodrigues Petrus

Universidade de São Paulo - USP 
I dedicate this study to God for supporting me during this journey. 


\section{BIOGRAPHY}

Marluci Palazzolli da Silva was born in Itu, located in the state of São Paulo in Brazil, on October 2, 1988. She graduated in Food Engineering at Universidade de São Paulo (USP) in 2012. During her undergraduate course, she performed two undergraduate research about Food Microbiology, which were granted by PIBIC/CNPq.

She worked at a dairy processing plant from 2012 to 2014, acting as an Industrial Processing Analyst. Her attributions were to manage and improve the production indicators, standardize the processes, and train the collaborators about Food Quality.

She joined to master's program in Food Engineering at USP in 2014. Her dissertation was about the encapsulation of probiotics and the development of functional semisweet chocolate, which was supervised by Professor Carmen Sílvia Fávaro Trindade and financed by São Paulo Research Foundation (FAPESP) (grant \#2014/10754-5).

In 2015, she got a scholarship abroad from FAPESP (grant \#2015/15300-5) to develop her research at L'Ecole Nationale Vétérinaire, Agroalimentaire et de l'Alimentation NantesAtlantique for 6 months. The main goal of this research was to encapsulate probiotics by coextrusion followed by fluidized bed drying, which Professor Denis Poncelet supervised.

She started her Ph.D. in 2017, studying the potential of co-encapsulation of guaraná extracts and probiotics with the supervision of Professor Carmen S. Fávaro Trindade and financed in part by the CAPES (Finance Code 001) and FAPESP (grant \#2016/24895-5).

She got a scholarship abroad from FAPESP (grant \#2019/09757-3) to develop her research at the University of California - Davis for 12 months, starting from October/2019. She worked with vacuum biosorption of plant extracts in probiotic cells, supervised by Professor Nitin Nitin. Unfortunately, she returned to Brazil before the planned due to the situation of the COVID-19 pandemic. 


\section{ACKNOWLEDGMENTS}

I thank God for all the blessings, giving me strength in the challenging moments that were important for learning.

Special thanks to my advisor, Prof. Dr. Carmen Sílvia Fávaro Trindade, for her guidance and support, which were essential for improving me as a student and person. She is an inspiration as a great leader and by her dedication at Universidade de São Paulo.

I thank to Coordenação de Aperfeiçoamento de Pessoal de Nível Superior - Brasil (CAPES) for the partial financial support (Finance Code -001).

I would like to express my gratitude to the São Paulo Research Foundation (FAPESP) for granting me scholarships during my master's degree (grant \#2014/10754-5), doctor's degree (grant \#2016/24895-5), and internships in France (grant \#2015/15300-5) and the United States of America (grant \#2019/09757-3). Additionally, all financial support to develop these studies.

I thank the Executive Commission of the Rural Economic Recuperation Plan in Cacao (Taperoá, Brazil), Sacco (Campinas, Brazil), Dairy processing plant from Universidade de Sao Paulo (Pirassununga, Brazil), Vô Nico (Pirassununga, Brazil), Ricaeli (Cabreúva, Brazil), Cargill (Itumbiara, Brazil), and Synergy Flavors (Vinhedo, Brazil) for donating materials to develop this project.

I thank to my colleagues at Laboratório de Encapsulação e Alimentos Funcionais (LENALIS) for all aid, also to the undergraduate students Mayara, Crícia, and Eduarda for assisting me with some experiments. Special thanks to Marcelo Thomazini, Specialist of LENALIS, for all his advice and patience over these years.

I thank Prof. Dr. Severino Matias Alencar, Dr. Adna Prado Massarioli, and Dr. Priscilla Siqueira Melo for assisting with the antioxidant analyses in their laboratory at ESALQ-USP. I thank to Prof. Dr. Milena Martelli Tosi for performing the microscopy confocal images in LMMC at Faculdade de Medicina de Ribeirao Preto (FMRP-USP).

Special thanks to Prof. Dr. Nitin Nitin and his students at the University of CaliforniaDavis for their attention and supervision during my internship abroad.

I want to thank all the FZEA-USP community, particularly the Department of Food Engineering, Library, Post-Graduation Section employees, for their support. I am grateful that I have been part of this community since my undergraduate.

I am thankful for my parents and grandparents, who always support my dreams.

Thank you all! 
"There are no secrets to success. It is the result of preparation, hard work, and learning from failure." 


\section{RESUMO}

\section{SILVA, M.P. Sistemas de entrega para ingestão simultânea de probióticos e extratos}

vegetais. 2021. 207 f. Tese (Doutorado) - Faculdade de Zootecnia e Engenharia de Alimentos, Universidade de São Paulo, Pirassununga, 2021.

A associação de extratos de plantas e probióticos é promissora para entrega simultânea de compostos funcionais no intestino trazendo inúmeros benefícios ao hospedeiro. Esse estudo teve por objetivos gerais (i) avaliar o potencial prebiótico e atividade antioxidante dos extratos do guaraná; (ii) co-encapsular probióticos e extratos do guaraná por coacervação complexa e avaliar a estabilidade e liberação desses materiais em fluidos gastrointestinais simulados (FGS); (iii) incorporar as microcápsulas contendo probiótico e extrato da semente do guaraná (ESG) e os mesmos ingredientes na forma livre em iogurte líquido; (iv) elaborar pasta de amendoim contendo probiótico e extrato da casca do guaraná (ECG) na forma livre e co-encapsulada; (v) avaliar cepas com potencial probiótico como carreadores para a biossorção à vácuo de extratos de plantas e avaliar a proteção dos compostos fenólicos, viabilidade do probiótico e liberação dos compostos fenólicos em FGS; (vi) verificar a sobrevivência dos probióticos biosorvidos com extratos de plantas em FGS. ESG e ECG apresentaram potencial antioxidante e prebiótico. Dessa maneira, a co-encapsulação melhorou a sobrevivência dos probióticos em fluidos gastrointestinais simulados e durante a estocagem. Aproximadamente $60 \%$ dos compostos fenólicos do ESG foram liberados no fluido gástrico. Por outro lado, os carotenoides presentes no ECG foram liberados gradualmente, alcançando uma taxa de liberação acumulada de $90 \%$ após a adição do fluido intestinal simulado. Em relação à produção do iogurte funcional, as microcápsulas contendo simultaneamente os probióticos e ESG mascararam o gosto amargo e evitaram a pós-acidificação do produto. A pasta de amendoim protegeu tanto os probióticos livres e encapsulados, sendo que o produto adicionado de ECG livre apresentou menor aceitação dos provadores. Na etapa final desse estudo, uma nova técnica baseada na biossorção à vácuo foi avaliada para carregar os compostos fenólicos dos extratos da casca da jabuticaba (ECJ) e ESG em cepas com potencial probiótico. Apesar das células dos probióticos carregarem entre 5 a 9 mg Ácido Gálico Equivalente - AGE/g, que são valores significativamente menores aos encontrados em micropartículas, a biossorção dos extratos das plantas em probióticos aumentou a hidrofobicidade das células em pelo menos três vezes. Além disso, em ensaio gastrointestinal simulado, a liberação dos compostos fenólicos biossorvidos variou entre 55\% e $75 \%$, enquanto que as contagens dos probióticos carregados com extratos das plantas foram 
mantidas. De maneira geral, a microencapsulação por coacervação complexa permitiu a veiculação de probióticos e compostos bioativos dos extratos do guaraná para elaboração de iogurte líquido e pasta de amendoim fortificados, além de manter os parâmetros de qualidade e sensoriais desses produtos. Já a técnica de biossorção à vácuo demonstrou-se bastante promissora para veicular probióticos viáveis carregados com ECJ e ESG no intestino, excluindo a necessidade de utilização de biopolímeros para proteção dos probióticos.

Palavras-chave: Coacervação Complexa. Guaraná. Fenólicos. Carotenóides. Iogurte. Pasta de Amendoim. Biossorção à vácuo. Jabuticaba. 


\begin{abstract}
SILVA, M.P. Delivery systems for simultaneous intake of probiotics and plant extracts. 2021. 207 f. Thesis - Faculdade de Zootecnia e Engenharia de Alimentos, Universidade de Sao Paulo, Pirassununga, 2021.
\end{abstract}

The association of plant extracts and probiotics is promising for simultaneous delivery of functional compounds in the gut, providing numerous benefits to the host. This study presented as overall aims (i) to assess the prebiotic potential and antioxidant activity of guaraná extracts; (ii) to co-encapsulate probiotics and guaraná extracts by complex coacervation and evaluate the stability and release in simulated gastrointestinal fluids (SGF); (iii) to incorporate microcapsules loaded simultaneously with probiotic and guaraná seed extract (GSE) and the same ingredients in free form in yogurt drink; (iv) to elaborate peanut butter containing free and co-encapsulated probiotic and guraná peel extract (GPE); (v) to evaluate strains with probiotic potential as carries for vacuum biosorption of plant extracts and evaluate the protection of phenolic compounds, probiotic viability, and release of phenolics in SGF; (vi) to verify the survivability of probiotic cell loaded with plant extracts in SGF. GSE and GPE showed antioxidant and prebiotic potential. In this way, co-encapsulation improved the survival of probiotics in simulated gastrointestinal fluids and during storage. In addition, approximately $60 \%$ of phenolic compounds from GSE were released into the gastric fluid. In contrast, the carotenoids present in GPE were gradually released, reaching an accumulative release rate of 90\% after the addition of simulated intestinal fluid. Regarding the production of functional yogurt, the microcapsules simultaneously loaded with probiotics and GSE masked the bitter taste and avoided post-acidification of the product. Peanut butter protected both free and encapsulated probiotics, and the product added with free GPE showed lower acceptance by the tasters. In the final stage of this study, a novel technique based on vacuum biosorption was evaluated to bind phenolic compounds from jabuticaba peel extract (JPE) and GSE into potential probiotic strains. Although probiotic cells loaded between 5 to $9 \mathrm{mg}$ Gallic Acid Equivalent - GAE/g, which were values significantly lower than those found in microparticles, the biosorption of plant extracts in probiotics increased the hydrophobicity of the cells by at least 3-fold. Furthermore, the release of phenolic compounds bound in cells ranged between $55 \%$ and $75 \%$ in simulated gastrointestinal fluids, while the counts of probiotics loaded with plant extracts were maintained. Overall, microencapsulation by complex coacervation allowed the delivery of probiotics and bioactive compounds from guaraná extracts to develop fortified 
yogurt drink and peanut butter, maintaining the quality and sensory parameters of these products. Vacuum biosorption is a promising technology for delivering viable probiotics loaded with JPE and GSE in the gut, excluding the need to use biopolymers to protect the probiotics.

Keywords: Complex coacervation. Guaraná. Phenolics. Carotenoids. Yogurt. Peanut butter. Vacuum biosorption. Jabuticaba. 


\section{LIST OF FIGURES}

Figure 1 - Schematic representation of this study.

Figure 2 - Promising benefits and biological properties of phytochemicals and probiotics on human health. 48

Figure 3 - Some possible adhesion mechanisms of phenolic compounds that positively influence the probiotic (gray rod-shaped bacteria) adhesion in the gut.

Figure 4 - Some examples of delivery systems for simultaneous intake of probiotics and bioactive compounds from plant extracts.

Figure 5 - Graphical abstract of the present study. 80

Figure 6 - Hydrophobicity of probiotics cultured in MRS broth or supplemented MRS broth with $10 \%(\mathrm{v} / \mathrm{v})$ of guaraná seeds extract (GSE), or guaraná peels extract (GPE). 90

Figure 7 - Confocal microscopy of coacervates (A, B, C), followed by the aspect of powders after freeze-drying (D, E, F) and their micrographs by scanning electron microscopy (G, H, I). In this figure: A, D, G are coacervates containing probiotic (control), B, E, H are coacervates containing probiotic and guaraná peel extract (GPE), C, F, I are coacervates containing probiotic and guaraná seed extract (GSE). .93

Figure 8 - Figure 3 - Release of probiotics in simulated gastric fluid (SGF) for 120 min, sequentially added to the simulated intestinal fluid (SIF) until complete $240 \mathrm{~min}$ of the assay, expressed as percentages (\%), considering the initial number of viable cells in coacervates. In this Figure: the black line is the control coacervate loaded with L. paracasei BGP-1 (LP); the brown line is the coacervate loaded with LP and guarana seed extract (GSE); the blue line is the control coacervate loaded with $B$. animalis subsp. lactis BLC-1 (B); the red line is the coacervate loaded with B and guaraná peel extract (GPE).

Figure 9 - Micrographs and accumulated release of encapsulated phenolic compounds from GSE (A) and carotenoids from GPE (B) in simulated gastric fluid (SGF) for $120 \mathrm{~min}$, sequentially adding the simulated intestinal fluid (SIF), completing 240 min of the assay. Values are mean \pm standard error (SE) ( $n=3$ analytical replicates). Reference: Own source. 
Figure 10 - Summary of this study: (1) evaluation of co-encapsulation of probiotic and guaraná seed extract (GSE) by complex coacervation regards viability of probiotic and stability of phenolic compounds and (2) application of microcapsules to enrich yogurt drink formulations, verifying their quality and sensory acceptance.

Figure 11 - Stability of freeze-dried microcapsules loaded with L. paracasei BGP-1 (LP) and guaraná seed extract (GSE), regarding total phenolic content (TPC) (A), epicatechin (B) and catechin (C) contents stored at $7{ }^{\circ} \mathrm{C}$ for 60 days. Viability of LP loaded in control microcapsules (without GSE) and LP simultaneously loaded with GSE in microcapsules (D) during the storage. Bars with the same lower letters of the same formulation are not statistically different. Bars with the same upper letters in the same time interval are not statistically different $(p>0.05)$.

Figure 12 - Micrographs of microcapsules and yogurts formulations. In this Figure: (A) rehydrated microcapsules loaded with L. paracasei BGP-1 (control microcapsule), (B) rehydrated microcapsules simultaneously loaded with L. paracasei BGP-1 and guaraná seed extract (GSE) (microcapsule LP+GSE), (C) yogurt drink supplemented with encapsulated $L$. paracasei BGP-1 - YE, (D) yogurt drink simultaneously supplemented with free $L$. paracase $i$ BGP-1 and GSE - YFGSE, and (E) yogurt drink supplemented with encapsulated L. paracasei

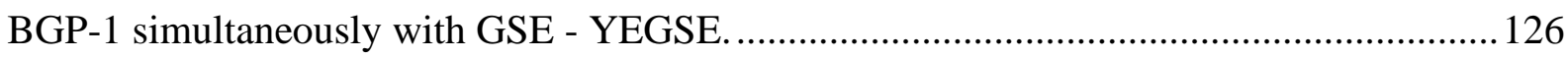

Figure 13 - Evaluation of $\mathrm{pH}(\mathrm{A})$, titratable acidity (TA) (B), color parameters L* (C), a* (D), $\mathrm{b}^{*}(\mathrm{E})$, total phenolic content (TPC) (F) and viability of free and encapsulated L. paracase $i$ BGP-1 (G) in yogurt drink during the storage at $7^{\circ} \mathrm{C}$ for 28 day. In this Figure: black bar is the control formulation (regular yogurt), white bar is the yogurt containing free probiotic (YF), white bar filled with dots is the yogurt containing encapsulated probiotic (YE), orange bar is the yogurt containing free probiotic and GSE (YFGSE) and orange bar filled with dots is the yogurt containing co-encapsulated probiotic and GSE (YEGSE). Bars with the same upper letters in the same time interval are not statistically different. Bars with the same lower letters of the same formulation are not statistically different $(\mathrm{p}>0.05)$.

Figure 14 - Micrographs of microcapsules produced by complex coacervation using an objective with 10x, and particle size distribution. In this Figure: (A) Control microcapsules composed by gelatin/Arabic gum and Bifidobacterium animalis subsp. lactis BLC-1, (B) microcapsules composed by gelatin/Arabic gum, B. animalis subsp. lactis BLC-1 and guaraná peel extract (GPE), and (C) particle size distribution of microcapsules. 
Figure 15 - Total carotenoids of free guaraná peel extract (GPE) stored at $25^{\circ} \mathrm{C}$ (graph A) and microcapsules loaded with Bifidobacterium animalis subsp. lactis BLC-1 (B) and GPE held at $7{ }^{\circ} \mathrm{C}$ and $25^{\circ} \mathrm{C}$ up to 90 days (graph B), and enumeration of encapsulated probiotics (graph C). In this Figure: yellow bars are unencapsulated GPE stored at $25^{\circ} \mathrm{C}$, yellow bars filled with dots are the microcapsules loaded with GPE and B. animalis subsp. lactis BLC1 (B) stored at $25^{\circ} \mathrm{C}$, black bars are the microcapsules loaded with GPE and B stored at $7^{\circ} \mathrm{C}$, white bars are the microcapsules loaded with B stored at $25^{\circ} \mathrm{C}$, white bars filled with lines are the microcapsules loaded with B stored at $7^{\circ} \mathrm{C}$.

Figure 16 - Characterization of peanut butter formulations during the storage, regarding $\mathrm{pH}(\mathrm{A})$, water activity - Aw (B), total phenolic content (C), $\alpha$-tocopherol content (D), oxidation by TBARS (E) and viability of probiotic (F). In this figure, control is the regular peanut butter formulation represented as blank bars, PBF is the peanut butter containing free probiotic represented as brown bar, $\mathrm{PBE}$ is the peanut butter containing encapsulated probiotic represented as brown bars filled with dots, PBGF is the peanut butter containing with free probiotic and guaraná peel extract represented as yellow bars, and PBGE is the peanut butter containing co-encapsulated probiotic and guaraná peel extract represented as yellow bar filled with dots. 153

Figure 17 - Panelist's profile regards the age group (A), consumption preference of peanut butter formulation (B) and the relevant aspects for purchase decision of peanut butter (C). The sensory attributes scores (D) and purchase intention (E) for control peanut butter, peanut butter containing free probiotic (PBF), peanut butter containing encapsulated probiotic (PBE), peanut butter containing free probiotic and guaraná peel extract (PBGF) and peanut butter containing co-encapsulated probiotic and guaraná peel extract (PBGE).

Figure 18 - Schematic representation of the present study.

Figure 19 - Total phenolic content (TPC) in probiotic cells (A, C) and biosorption efficiency (B, D) after vacuum biosorption of jabuticaba peel extracts (JPW - jabuticaba peel in water, JP25\% - jabuticaba peel in 25\% ethanol and JP50\% - jabuticaba peel in 50\% ethanol), guaraná seed extract (GSE) and catechin. Probiotic cells strains were described as LC - L. casei, LR L. rhamnosus, LP - L. paracasei.

Figure 20 - Total phenolic content (TPC) in probiotic cells (A, C) and biosorption efficiency (B, D) after passive of jabuticaba peel extract (JPW - jabuticaba peel in water, JP25\% - 
jabuticaba peel in 25\% ethanol and JP50\% - jabuticaba peel in 50\% ethanol), guaraná seed extract (GSE) and catechins. Probiotic cells strains were described as LC - L. casei, LR - L. rhamnosus, LP - L. paracasei.

Figure 21 - Micrographs of probiotic cells after vacuum biosorption (VB) of ethanol 25\% (controls), JP25\% - jabuticaba peel in 25\% ethanol, and GSE - guaraná seed extract. In this figure: A) L. rhamnosus (LR) loaded with ethanol 25\%; B) LR loaded with JP25\%; C) L. casei (LC) loaded with ethanol 25\%; D) LC loaded with JP25\%; E) L. paracasei (LP) loaded with ethanol; F) LP loaded with JP25\%; G) LC loaded with ethanol 25\%; H) LC loaded with GSE.

Figure 22 - Release of PC from probiotic cells loaded with JP25\% - jabuticaba peel in 25\% ethanol (A), GSE - guaraná seed extract (B) and catechins (C) in simulated gastric fluid (SGF) and sequential addition of simulated intestinal fluid (SIF), expressed as percentage of TPC released in the fluids. In this Figure: LC - L. casei loaded with phenolic compounds from plant extracts or catechin standard, LR - L. rhamnosus loaded with phenolic compounds from plant extracts or catechin standard, LP - L. paracasei loaded with phenolic compounds from plant extracts or catechin standard.

Figure 23 - Growth curves of probiotic cells (A) Lacticaseibacillus paracasei BGP-1, (B) Lacticaseibacillus casei and (C) Lacticaseibacillus rhamnosus GG in control MRS broth (blue line) and MRS broth supplemented with watery jabuticaba peel extract (orange line), hydroalcoholic jabuticaba peel extract (gray line), guaraná seed extract (yellow line), catechin solution at concentrations $181.8 \mu \mathrm{g} / \mathrm{mL}$ (light blue line) $90.9 \mu \mathrm{g} / \mathrm{mL}$ (green line) and 45.4 $\mu \mathrm{g} / \mathrm{mL}$ (black line). 204

Figure 24 - Survivability of probiotic cells during in vitro digestion test. Cells were added in simulated gastric fluid (SGF) for $2 \mathrm{~h}$, followed by the addition of simulated intestinal fluid (SIF), completing 4 h. In this figure: LC - L. casei, LR - L. rhamnosus, LP - L. paracasei, control cells loaded with ethanol $25 \%$, catechin -cells loaded with catechin, J25\% - cells loaded with jabuticaba peel extract, GSE - cells loaded with guaraná seed extract (GSE)......................206

Figure 25 - Metabolic activities of L. casei (LC), L. paracasei (LP) and L. rhamnosus (LR) cells before (blue line) and after the in vitro exposure of gastric fluid without the addition of pepsin (red line) or with pepsin (green line), expressed as fluorescence intensity by time. In this figure: graphs in first row - control cells loaded with ethanol $25 \%$ by vacuum, graphs in second row - 
cells loaded with catechin solution, graphs in third row - cells loaded with guaraná seed extract (GSE) and graphs in fourth row - cells loaded with jabuticaba peel extract (JP25\%)..........208 


\section{LIST OF TABLES}

Table 1 - Impact of phenolic compounds from plants in human health.

Table 2 - Co-encapsulation of probiotics and plant extracts, correlating techniques, materials and main outcomes.

Table 3 - Antioxidant activity of guaraná seeds extract (GSE) and guaraná peels extract (GPE).

Table 4 - Enumeration of L. paracasei BGP-1 (LP) and B. animalis subsp. lactis BLC-1 (B) populations cultured in MRS broth (control) and MRS broth supplemented by guaraná seed extract (GSE) and guaraná peel extract (GPE), expressed as log CFU/mL.

Table 5 - Characterization of microcapsules containing probiotics L. paracasei BGP-1 (LP) or B. animalis subsp. lactis BLC-1 (B), or microcapsules loaded simultaneously with probiotic and guaraná seed extract (GSE) or guaraná peel extract (GPE). Microcapsules were evaluated regarding the enumeration of probiotics after freeze-drying, total phenolic content (TPC), total carotenoids (TC) and average size.

Table 6 - Bioactive compounds content after atomization of guaraná seed extract (GSE) and retention, expressed as $\mathrm{mg}$ g- 1 on a dry basis and percentage (\%), respectively.

Table 7 - Proximate composition of functional yogurt drink formulations.

Table 8 - Sensory attributes of functional yogurt drinks using a 9-point hedonic scale $(1=$ dislike extremely and $9=$ like extremely)

Table 9 - Proximate composition of functional peanut butter formulations.

Table 10 - Texture parameters of peanut butter formulations at the beginning of storage and after 90 days at $25^{\circ} \mathrm{C}$.

Table 11 - Phenolic compounds (PC) extracted from jabuticaba peel using different ethanolic solutions and pure water, expressed as $\mathrm{mg} \mathrm{GAE} / \mathrm{g}$ of dried material.

Table 12 - Stability of phenolic compounds encapsulated in Lacticaseibacillus cells, expressed as $\mathrm{mg} \mathrm{GAE} / \mathrm{g}$ of cell. 
Table 13 - Viability of probiotic cells, L. casei (LC), L. paracasei (LP) and L. rhamnosus (LR) after biosorption by vacuum (V) or passive (P) mechanisms and freeze-drying, expressed as log $\mathrm{CFU} / \mathrm{g}$.

Table 14 - Viability of L. casei (LC), L. paracasei (LP) and L. rhamnosus (LR) after 15 and 30 days of storage at $25^{\circ} \mathrm{C}$, expressed as $\log \mathrm{CFU} / \mathrm{g}$.

Table 15 - Hydrophobicity of probiotic cells before (first column) and after vacuum biosorption (VB). 


\section{LIST OF ABBREVIATIONS AND ACRONYMS}
ABTS
2,2'-azino-bis(3-
mg - Miligrams
ethylbenzothiazoline-6-sulfonic acid)
DPPH - 2,2-diphenyl-1-picrylhydrazyl
$\mathrm{mL}$ - Mililitros
MRS - Man, Rogosa e Sharpe
ORAC - Oxygen Radical Absorbance
Capacity
GAE - Galic Acid Equivalent
$\mathrm{pH}$ - Potential Hydrogen
OD - Optical density
rpm - Revolutions Per Minute
SGF - Simulated Gastric Fluid
TPC - Total Phenolic Content
SIF - Simulated Intestinal Fluid
TC - Total Carotenoids
$\mathrm{g}-\mathrm{Gram}$
CFU - Colony Forming Units
GRAS - Generally Recognized as Safe
${ }^{\circ} \mathrm{C}$ - Degree Celsius
GSE - Guaraná Seed Extract
$\mathrm{a}_{\mathrm{w}}-$ Water Activity
GPE - Guaraná Peel Extract
$\mathrm{HCl}$ - Hydrochloric acid
JPE - Jabuticaba Peel Extract
$\mathrm{NaOH}$ - Sodium hydroxide
HPLC - High Performance Liquid
v/v - Volume/Volume
Chromatography
w/v - Weight/Volume
$\mathrm{h}-$ hours
w/w - Weight/Weight
L - Liter
Log - Logarithm
SSF - Simulated Salivary Fluid
SGF - Simulated Gastric Fluid
SIF - Simulated Intestinal Fluid
SEM - Scanning Electron Microscope 


\section{SUMMARY}

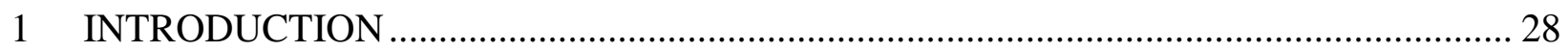

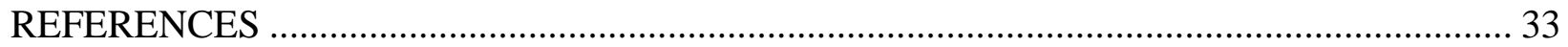

2 CHAPTER 1 - DELIVERY SYSTEMS FOR SIMULTANEOUS INTAKE OF PROBIOTICS

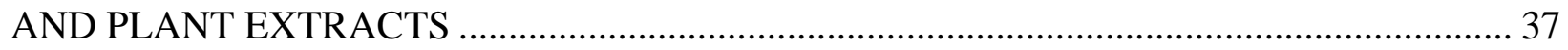

2 CHAPTER 1 - DELIVERY SYSTEMS FOR SIMULTANEOUS INTAKE OF PROBIOTICS

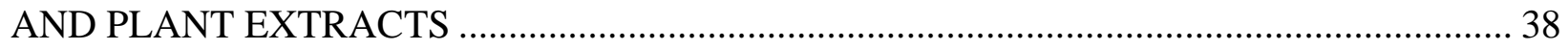

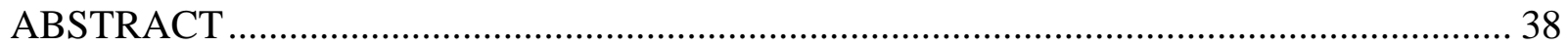

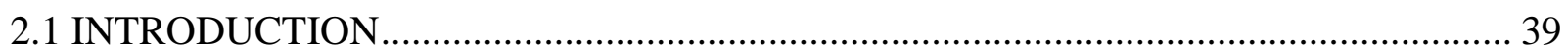

2.2 PHYTOCHEMICALS FROM PLANTS EXTRACTS IN HUMAN HEALTH ................. 40

2.2.1 Phenolic compounds-rich plant extracts in human health ............................................. 40

2.2.2 Potential of other phytochemicals from plants in gut modulation................................. 44

2.3 SUPPLEMENTATION OF PROBIOTICS FOR GUT MODULATION …………............ 45

2.4 BENEFICIAL ASSOCIATION OF PROBIOTICS AND PHENOLIC COMPOUNDS ... 47

2.4.1 Influence of phenolic compounds for probiotic adhesion in the gut ........................... 49

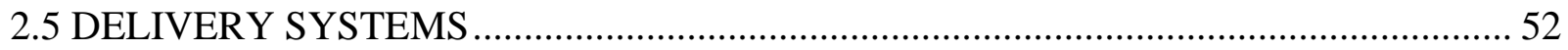

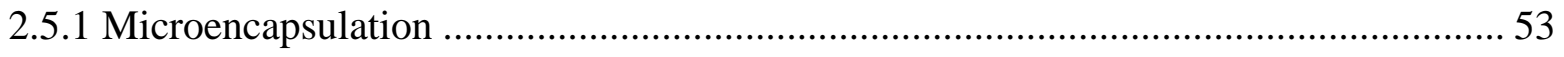

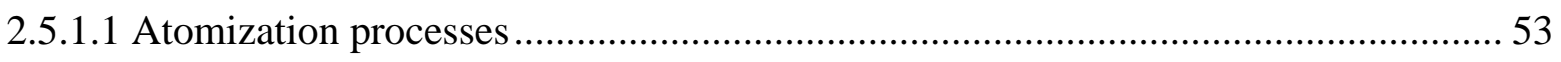

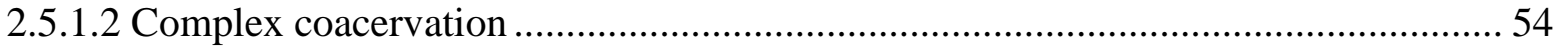

2.5.2 Simultaneous encapsulation of probiotics and plant extracts ........................................ 56

2.5.3 Biosorption as a future perspective for simultaneous intake of probiotics and phenolic

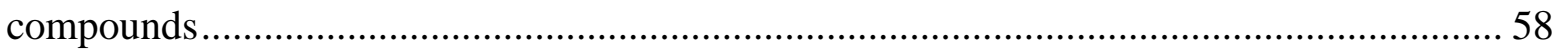

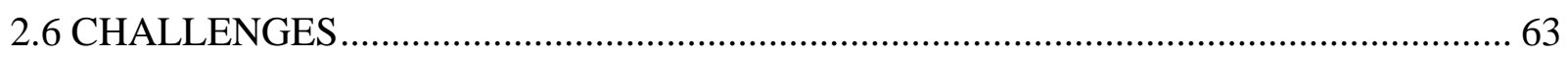

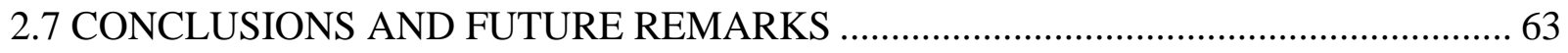

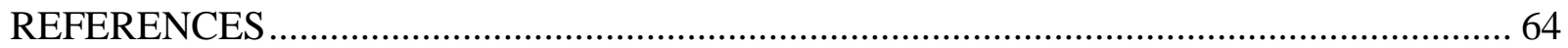

3 CHAPTER 2 - CO-ENCAPSULATION OF GUARANÁ EXTRACTS AND PROBIOTICS INCREASES PROBIOTIC SURVIVABILITY AND SIMULTANEOUSLY DELIVERS BIOACTIVE COMPOUNDS IN SIMULATED GASTROINTESTINAL FLUIDS ………....... 76

3 CHAPTER 2 - CO-ENCAPSULATION OF GUARANÁ EXTRACTS AND PROBIOTICS INCREASES PROBIOTIC SURVIVABILITY AND SIMULTANEOUSLY DELIVERS BIOACTIVE COMPOUNDS IN SIMULATED GASTROINTESTINAL FLUIDS .................. 77 


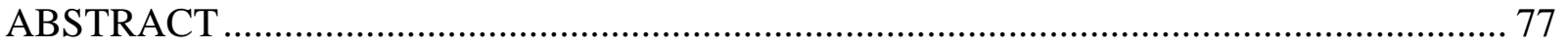

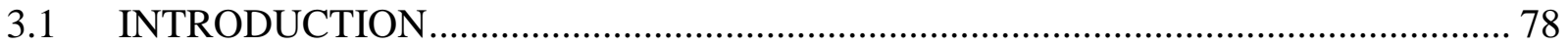

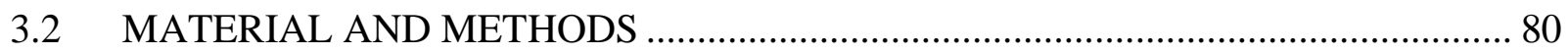

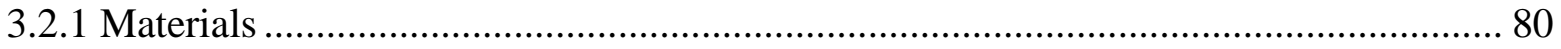

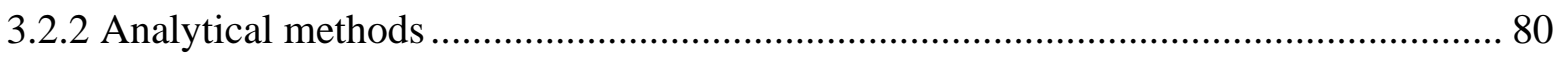

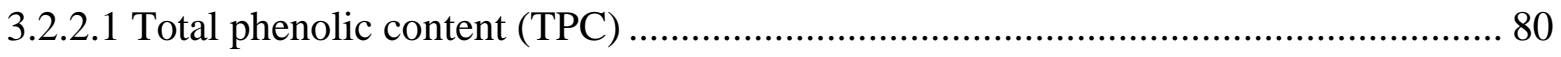

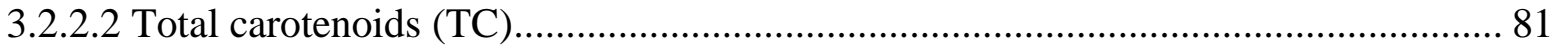

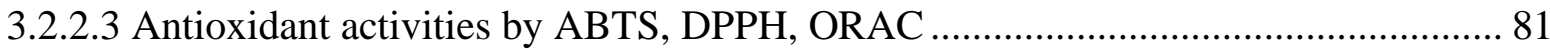

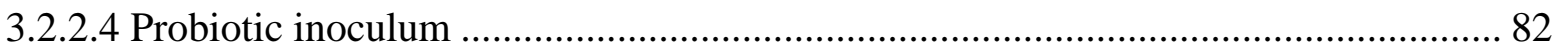

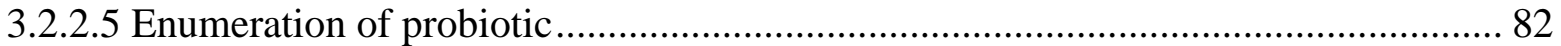

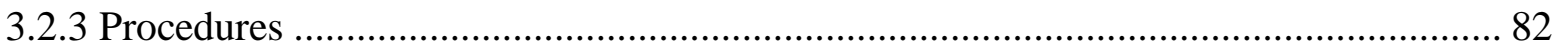

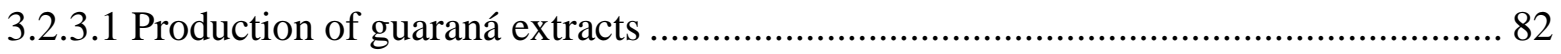

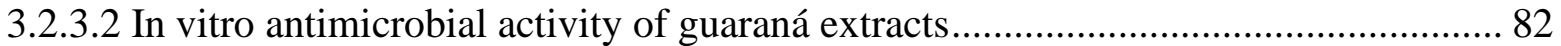

3.2.3.3 Influence of guaraná extracts on the growth of probiotics ....................................... 83

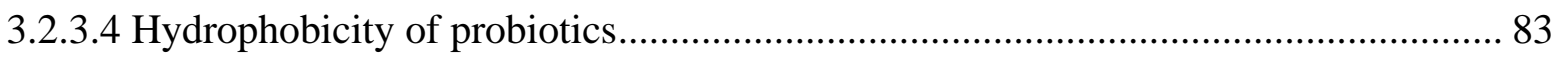

3.2.3.5 Simultaneous encapsulation of probiotic and guaraná extracts ................................. 84

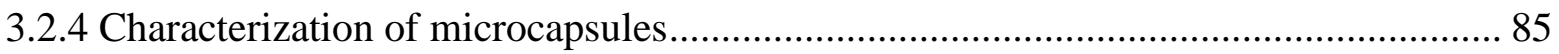

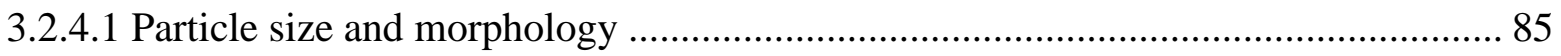

3.2.4.2 Quantification of total phenolic content (TPC), total carotenoids (TC) and enumeration

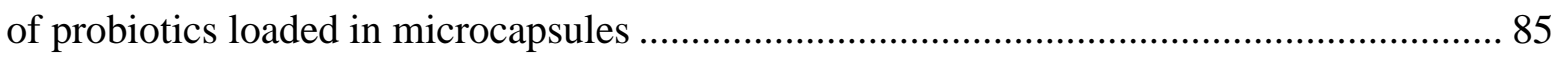

3.2.4.3 Release of encapsulated probiotic and bioactive compounds in simulated

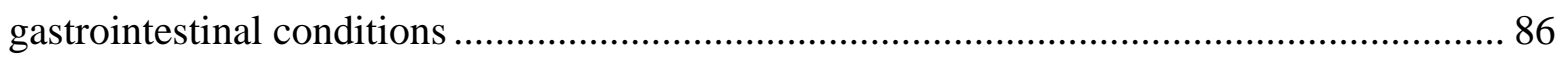

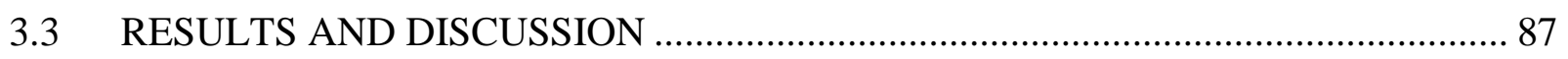

3.3.1 Antioxidant activity of guaraná extracts ................................................................. 87

3.3.2 Antimicrobial activity and effect of guaraná extracts in the multiplication of probiotics 87

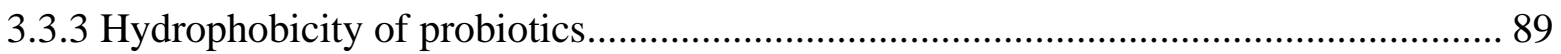

3.3.4 Characterization of microcapsules: morphology and particle size .............................. 92

3.3.5 Enumeration of probiotics and evaluation of total phenolic content and total carotenoids after encapsulation ..................................................................................... 94

3.3.6 Release of encapsulated probiotics in simulated gastrointestinal fluids....................... 96

3.3.7 Release of phenolic compounds and carotenoids in simulated gastrointestinal fluids. 98 


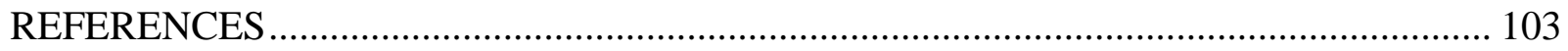

4 CHAPTER 3 - FORTIFICATION OF YOGURT DRINK WITH MICROCAPSULES LOADED WITH Lacticaseibacillus paracasei BGP-1 AND GUARANÁ SEED EXTRACT 109

4 CHAPTER 3 - FORTIFICATION OF YOGURT DRINK WITH MICROCAPSULES LOADED WITH Lacticaseibacillus paracasei BGP-1 AND GUARANÁ SEED EXTRACT. 110

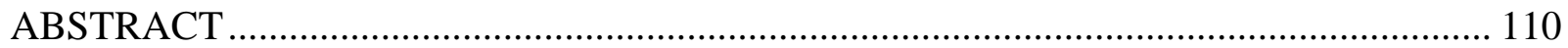

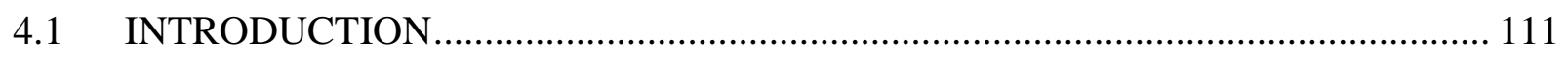

4.2 MATERIAL AND METHODS ……………………………………………….... 113

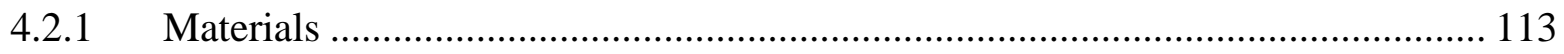

4.2.2 Preparation of GSE followed by atomization ................................................. 113

4.2.3 Quantification of total phenolic content (TPC) .................................................... 114

4.2.4 Quantification of catechin, epicatechin and methylxanthine content ................... 114

4.2.5 Simultaneous encapsulation of potential probiotic and GSE............................... 115

4.2.6 Characterization of the microcapsules: average size, viability of encapsulated L. paracasei and stability of TPC and polyphenols........................................................... 115

4.2.7 Application of microcapsules in yogurt drink ................................................. 116

4.2.8 Optical microscopy of microcapsules and yogurt drink supplemented with free and co-encapsulated L. paracasei with GSE ....................................................................... 117

4.2.9 Physicochemical characteristics of yogurt formulations ..................................... 117

4.2.10 Evaluation of functional yogurt drink during storage at $7{ }^{\circ} \mathrm{C}$ for 28 days............ 117

4.2.11 Sensory acceptance test........................................................................................ 118

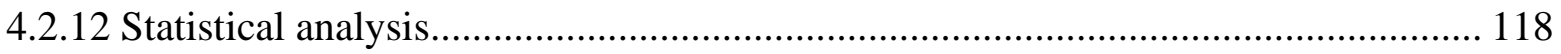

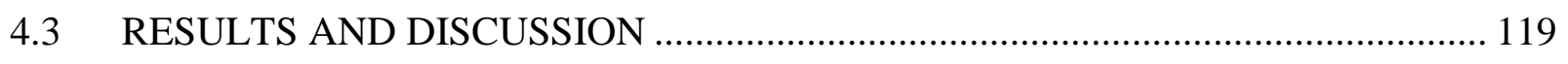

4.3.1 Evaluation of spray-dried GSE ..................................................................... 119

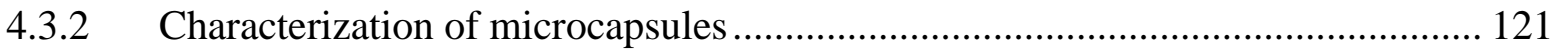

4.3.2.1 Volume weight mean diameter $\left(\mathrm{D}_{4,3}\right)$, stability of TPC and viability of $L$. paracasei........................................................................................................ 121

4.3.3 Characterization of yogurt formulations ........................................................... 124

4.3.3.1 Optical microscopy of yogurt drink formulations supplemented with microcapsules 124

4.3.3.2 Physicochemical characteristics of yogurt drink formulations: proximate composition, $\mathrm{pH}$, titratable acidity (TA), color and TPC 125 
4.3.3.3 Viability of free and encapsulated L. paracasei in yogurt drink during storage .. 130

4.3.3.4 Sensory acceptance .................................................................................. 130

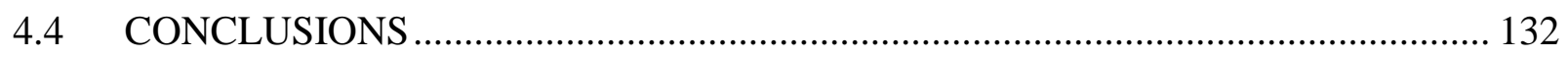

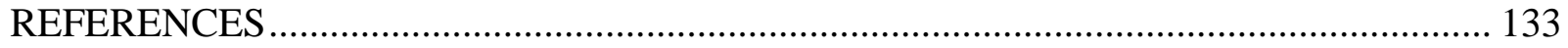

5 CHAPTER 4 - DEVELOPMENT OF FUNCTIONAL PEANUT BUTTER CONTAINING FREE AND ENCAPSULATED PROBIOTIC AND GUARANÁ PEEL EXTRACT .............. 138

5 CHAPTER 4 - DEVELOPMENT OF FUNCTIONAL PEANUT BUTTER CONTAINING FREE AND ENCAPSULATED PROBIOTIC AND GUARANÁ PEEL EXTRACT .............. 139

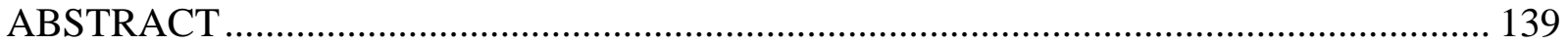

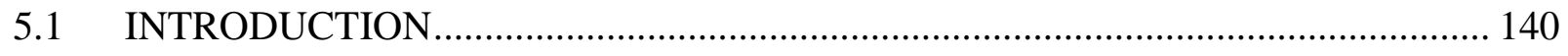

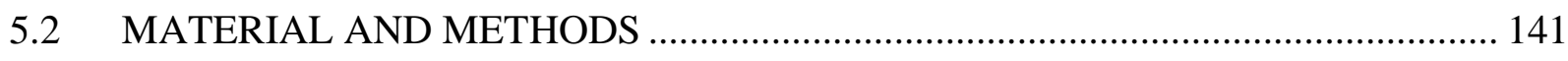

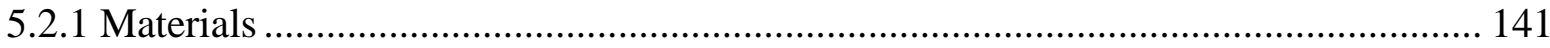

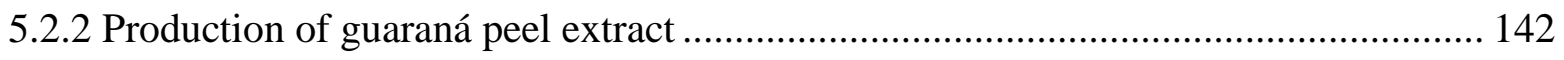

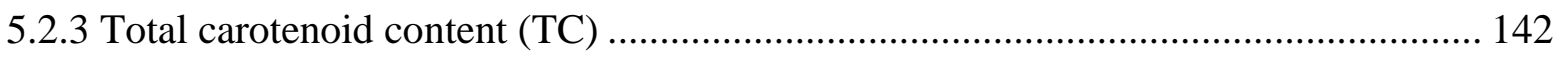

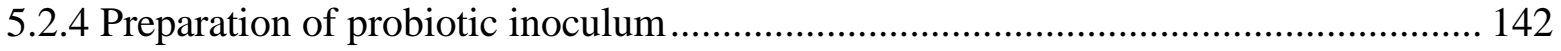

5.2.5 Encapsulation of probiotic and co-encapsulation of probiotic and GPE .................. 143

5.2.6 Characterization of microcapsules................................................................. 143

5.2.6.1 Morphology and particle size distribution.................................................. 143

5.2.6.2 Quantification of TC in free GPE and microcapsules during storage ................... 143

5.2.6.3 Enumeration of encapsulated probiotic during storage ..................................... 144

5.2.7 Application of microcapsules in peanut butter ................................................... 144

5.2.8 Quality parameters of peanut butter formulations ........................................... 145

5.2.8.1 Physical-chemical properties: physicochemical characterization, water activity $\left(\mathrm{A}_{\mathrm{w}}\right)$,

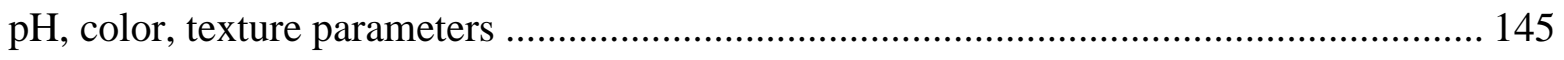

5.2.8.2 Evaluation of oxidation by thiobarbituric acid reactive substances (TBARS)....... 146

5.2.8.3 Quantification of total phenolic compounds (TPC) and $\alpha$-tocopherol in peanut butter

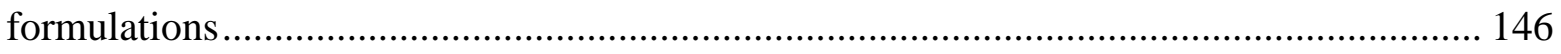

5.2.8.4 Viability of probiotic in peanut butter during storage ..................................... 147

5.2.8.5 Acceptance sensory test, profile of panelists and purchase intention.................... 147

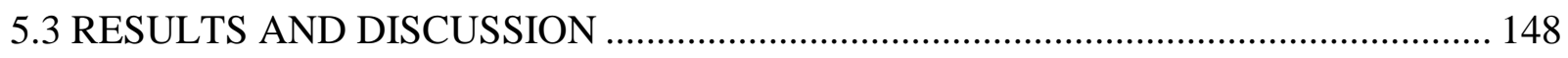

5.3.1 Characterization of microcapsules during the storage at $7^{\circ} \mathrm{C}$ and $25^{\circ} \mathrm{C} \ldots \ldots \ldots \ldots \ldots . . . . . .148$ 
5.3.1.1 Morphology, particle size distribution, total carotenoid content (TC) and viability of

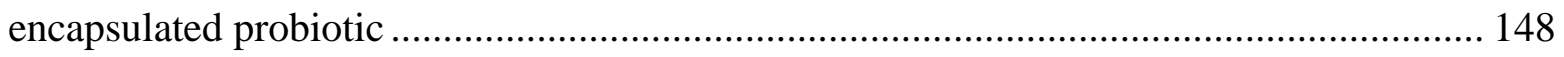

5.3.2 Characterization of peanut butter formulations stored at $25^{\circ} \mathrm{C}$ for 90 days .............. 151

5.3.2.1 Proximate composition, water activity $\left(\mathrm{A}_{\mathrm{w}}\right), \mathrm{pH}$, total color difference of the peanut

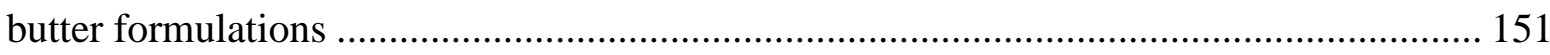

5.3.2.2 Phenolics, $\alpha$-tocopherol and oxidation by TBARS ............................................ 154

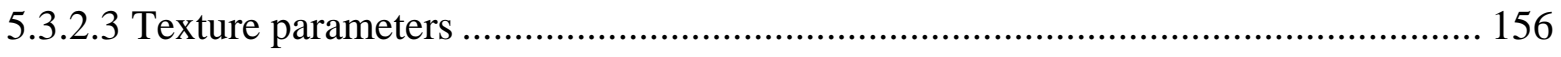

5.3.2.4 Viability of probiotic in peanut butter ................................................................ 158

5.3.3 Sensory evaluation: panelists' profile, acceptance test and purchase intention .......... 158

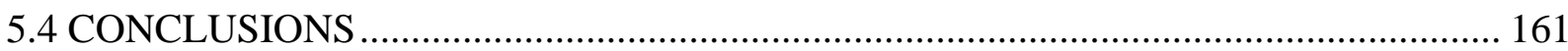

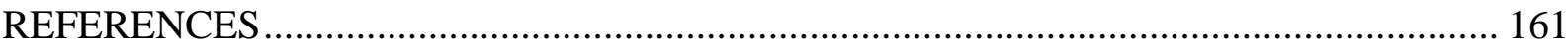

6 CHAPTER 5 - VACUUM-ASSISTED BIOSORPTION AS A PROMISING APPROACH FOR SIMULTANEOUS DELIVERY OF LIVE PROBIOTICS AND PLANT-PHENOLIC

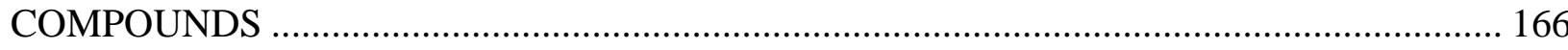

6 CHAPTER 5 - VACUUM-ASSISTED BIOSORPTION AS A PROMISING APPROACH FOR SIMULTANEOUS DELIVERY OF LIVE PROBIOTICS AND PLANT-PHENOLIC

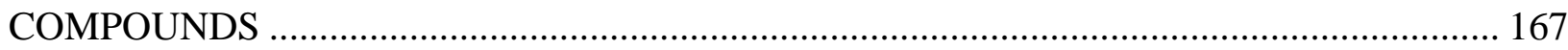

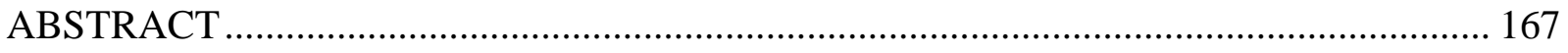

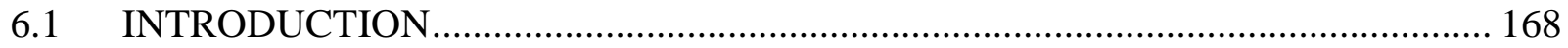

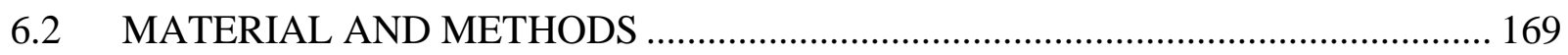

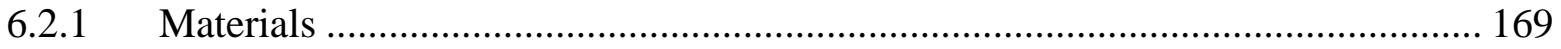

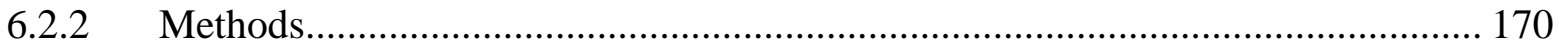

6.2.2.1 Production of phenolic-rich jabuticaba peel and guaraná seed (GSE) extracts .... 170

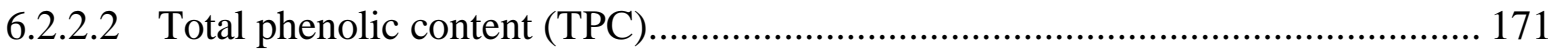

6.2.2.3 Activation of probiotic cells for encapsulation ................................................... 171

6.2.2.4 Biosorption of jabuticaba extracts (JPW, JP25\% and JP50\%) in probiotic cells: influence of ethanol concentration during vacuum and passive mechanisms ..................... 171

6.2.2.5 Biosorption of catechin solution and GSE in probiotic cells by vacuum and passive mechanisms: effect of polyphenols .............................................................................. 172

6.2.2.6 Biosorption efficiency and binding of TPC in cells........................................... 172

6.2.2.7 Viability of probiotic cells after biosorption and freeze-drying .......................... 173

6.2.2.8 Evaluation of biosorption of plant extracts in probiotic cells using multiphoton imaging 173 
6.2.2.9 Stability of PC from JP25\% loaded in probiotic cells during storage ................. 173

6.2.2.10 Release of phenolic compounds in simulated gastrointestinal conditions ........ 174

6.3 RESULTS AND DISCUSSION ................................................................... 174

6.3.1 Production of phenolic-rich jabuticaba peel and guaraná seeds (GSE) extracts .. 174

6.3.2 Vacuum biosorption of jabuticaba peel extracts, GSE and catechin in probiotic

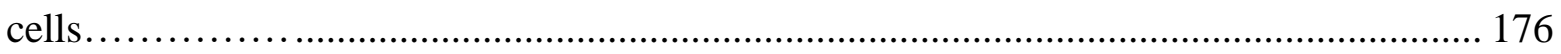

6.3.3 Passive Biosorption of jabuticaba peel extracts, GSE and catechin in probiotic

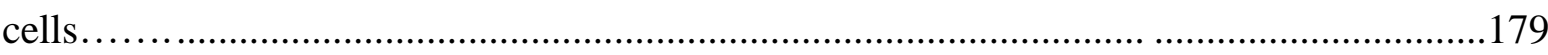

6.3.4 Multiphotonic microscopy and stability of TPC ......................................... 181

6.3.5 Release of PC in simulated gastrointestinal conditions ................................... 184

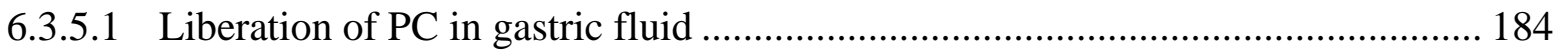

6.3.5.2 Liberation in intestinal fluid........................................................................ 185

6.3.6 Viability of probiotic cells after biosorption and freeze-drying ........................ 187

6.3.7 Viability of freeze-dried probiotics loaded with plants extracts and catechin during

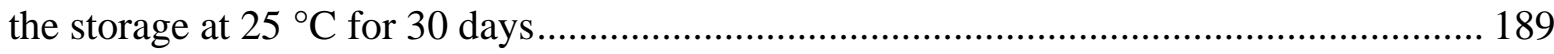

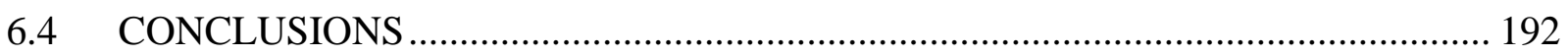

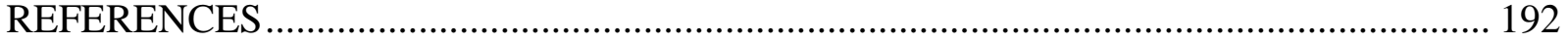

7 CHAPTER 6 - LOADING OF PHENOLIC COMPOUNDS IN PROBIOTIC CELLS IMPROVES THEIR SURVIVABILITY DURING IN VITRO DIGESTION ........................ 197

7 CHAPTER 6 - LOADING OF PHENOLIC COMPOUNDS IN PROBIOTIC CELLS IMPROVES THEIR SURVIVABILITY DURING IN VITRO DIGESTION ....................... 198

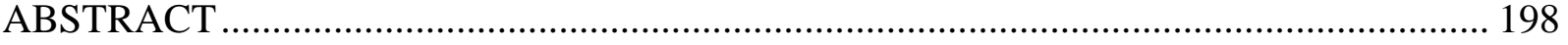

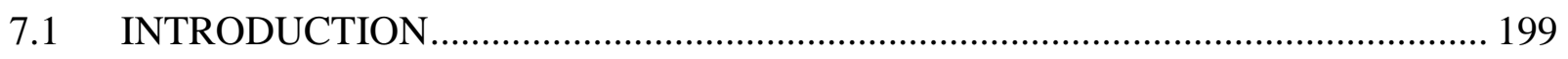

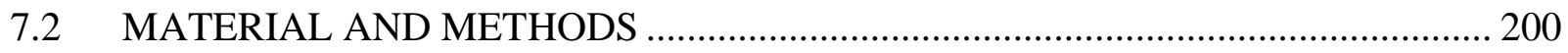

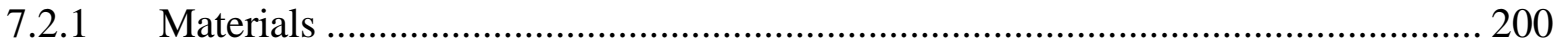

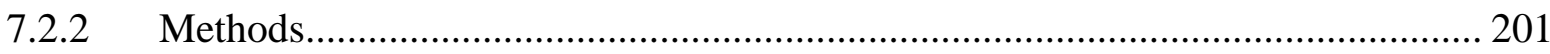

7.2.2.1 Production of extracts from jabuticaba peels and guaraná seed ............................ 201

7.2.2.2 Growth of probiotics in supplemented MRS broth with catechin solutions, jabuticaba

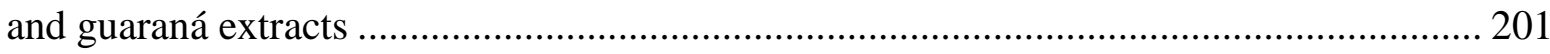

7.2.2.3 Vacuum biosorption of vegetable extracts and catechin solution in live probiotic cells 201

7.2.2.4 Hydrophobicity of probiotic cells ............................................................ 202

7.2.2.5 Survivability of probiotic cells during in vitro digestion test ............................. 202 
7.2.2.6 Fluorescence assay of metabolic activity of probiotic cells using resazurin 202

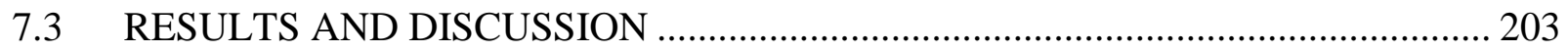

7.3.1 Growth of probiotic cells in supplemented MRS broth with plant extracts and catechin 203

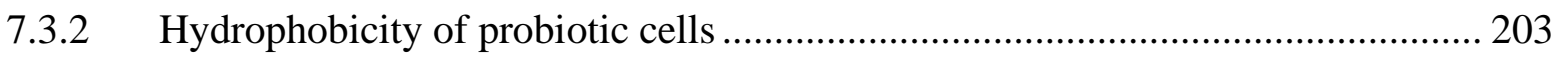

7.3.3 Survivability of probiotic cells during in vitro digestion test ............................... 204

7.3.4 Metabolic activity of infused cells after simulated gastric fluid ............................ 206

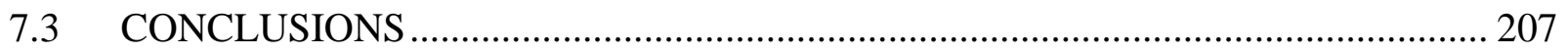

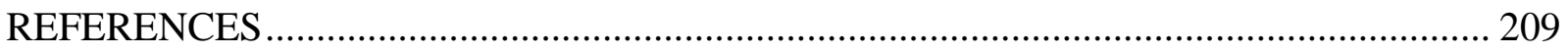

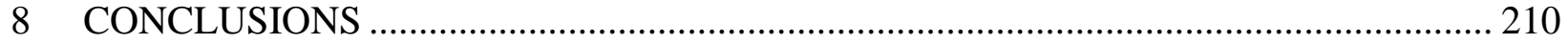

ATTACHMENT A - ACCEPTANCE OF THE RESEARCH ETHIC COMMITTEE FOR THE SENSORY ANALYSIS OF YOGHURT DRINKS AND PEANUT BUTTER ...................... 212 ATTACHMENT B - PAPER PUBLISHED IN “INTERNATIONAL DAIRY JOURNAL”... 214 ATTACHMENT C - PAPERS PUBLISHED IN COLLABORATION DURING THIS PERIOD 


\section{INTRODUCTION}

The Covid-19 pandemic has boosted the consumption of functional foods, dietary supplements, and herbal medicines since the public searches for products as a strategy to enhance overall health (ALTUN; ERMUMCU; KURKLU, 2020). Functional foods can be fortified, enriched, or natural, providing prospective health benefits associated with a varied diet (CROWE, FRANCIS, 2013; GRANATO, NUNES, BARBA, 2017). Furthermore, in the functional food market, the supplementation of probiotics, prebiotics, and phytochemicals stands out to enhance health, leading to further investigations about food matrices to incorporate them and technological approaches to achieve these goals.

Probiotics are "live microorganisms that, when administered in adequate amounts, confer a health benefit on the host" (HILL et al., 2014). Although their benefits are strain-specific, the core aid associated with the administration of probiotics is improved digestive tract and immune system (HILL et al., 2014). Also, some recent studies have reported the positive effect of probiotics and the crosstalk among intestinal microbiota and other vital organs, such as brain and lungs, denominated as gut-brain and gut-lung axles, respectively (BORRELLI et al., 2016; DANG; MARSLAND, 2019). Concerning the recommended dose of probiotics to provide health benefits, this estimative varied among the studies, depending on the probiotic strain and the health status of the studied population (BERTAZZONI et al., 2013).

Another relevant definition is prebiotic, which was recently updated as "a substrate that is selectively utilized by host microorganisms conferring a health benefit" (GIBSON et al., 2017). Some prebiotics carbohydrates-based are well-established, such as inulin, polydextrose, fructooligosaccharides (FOS), lactulose, etc. Other prebiotic candidates are plant phenolics since most reach the colon for colonic biotransformation (GIBSON et al., 2017). Besides that, polyphenols may contribute to the proliferation of beneficial gut microbiota, reducing the pathogenic species, depending on the polyphenol dose (MA; CHEN, 2020). However, further studies are necessary to verify if all phenolic molecules could provide benefits.

Phytochemicals are compounds found in plants, which can be classified as water-soluble and lipid-soluble, e.g., polyphenols and carotenoids, respectively (MARTEL et al., 2020; NEILSON; GOODRICH; FERRUZZI, 2017). Polyphenols are known for their anticarcinogenic, 
antioxidant, antimicrobial, and prebiotic potential. Similarly, carotenoids display biological properties by antioxidant, anticarcinogenic, and provitamin A activities (SANTOS et al., 2021). Although their mechanisms of action as antioxidants differ, phytochemicals could reduce the oxidative stress of probiotic cells, which is the leading cause of probiotic death. Thus, simultaneous delivery of probiotics and plant extracts can be a technological approach to improve their survivability and provide other health benefits.

Among Amazon plants, guaraná (Paullinia cupana) is a fruit known for its medicinal and stimulating properties. Guaraná seeds are used to produce energy drinks, commercial powder for supplementation in smooths, and cosmetic products due to the presence of caffeine. In addition, some benefits of the guaraná seeds intake are reducing mental fatigue and improving cognitive effect (KENNEDY et al., 2008). Recently, Yonekura et al. (2016) evaluated the bioavailability of phenolic compounds in commercial guaraná powder. These authors verified that oxidative stress markers of patients were favored by direct antioxidant action of absorbed catechins and upregulation of antioxidant and detoxifying enzymes. These results demonstrated the potential of using guaraná seeds to improve health.

According to the systematic survey of agricultural production conducted by the Brazilian Institute of Geography and Statistics - IBGE (2020), the output of guaraná was 2,704 tons in 2020. During the processing of guaraná, the fruit is not fully used, and only its seeds are used to produce energy drinks and powdered guaraná. Although there is no data concerning the amount of waste generated during guaraná processing, we estimated that $50 \%$ of the guaraná is discarded. Thus, approximately 1,352 tons of waste are generated per year. Guaraná peels are used mainly to produce fertilizer which is a derisory purpose considering the richness of bioactive, such as the carotenoids (PINHO et al., 2021). Thus, guaraná seeds and peels were used to produce phenolicrich extract and carotenoid-rich extract, respectively, evaluating their antioxidant capacity and prebiotic potential to preserve the viability of probiotics by co-encapsulation.

Another valuable food by-product is the jabuticaba peels due to the presence of phenolic compounds. In 2017, the annual production of jabuticaba in Brazil was around 3,751 tons (IBGE, 2017), generating about 1,875 tons of waste. Despite this significant amount of jabuticaba byproduct generated, some studies have explored their functionality due to antiobesity potential and improvement of insulin sensibility (LENQUISTE et al., 2019). Another study evaluated the 
incorporation of jabuticaba peel extract in probiotic Petit Suisse, demonstrating the improvement of the survivability of Lactobacillus acidophilus (PEREIRA et al., 2016). However, these authors reported that jabuticaba peel extract did not enhance the viability of Bifidobacterium lactis in Petit Suisse, showing that the positive effects of this plant extract are dependent on the probiotic strain. Massa et al. (2020) evaluated the prebiotic potential of digested jabuticaba by-products, reporting the high viability of probiotics and increased lactic acid and short-chain fatty acids.

The incorporation of probiotic strains in food matrices containing phytochemicals is widely explored in the literature, such as fermentable fruit juices by incorporation of probiotics (PEREIRA et al., 2011), jussara sorbet (MARINHO et al., 2019), and chocolate (SILVA et al., 2017). However, some probiotic strains are sensitive to the low pH, high temperature, presence of oxygen, among others, limiting their technological potential (FÁVARO-TRINDADE; HEINEMANN, PEDROSO, 2011). In this way, Lacticaseibacillus paracasei BGP-1 and Bifidobacterium animalis subsp. lactis BLC-1 reduced their survivability rates during in vitro digestion tests (HOLKEM; FAVARO-TRINDADE; LACROIX, 2020; MATOS-JR et al., 2019; SILVA et al., 2017), hindering their incorporation in food matrices. Similarly, bioactive compounds are unstable to the harsh conditions of processing or storage. In addition, another challenge is the need for these bioactive compounds and probiotics to reach the gut for providing health benefits. Some barriers during digestion are the low $\mathrm{pH}$ of stomach and bile salts, which could degrade these bioactive compounds or cause the death of probiotics. Thus, the microencapsulation technology, which is based on packing the interest's materials, may reduce this environmental stress. Another advantage of microencapsulation is the possibility of fortifying and enriching some food matrices, developing healthier products.

Several encapsulation techniques are investigated to protect probiotics and plant extracts, combining different carriers that may contribute to the controlled release in the target. Among the methods, spray chilling and complex coacervation are explored in our research group for protection of probiotics and plant extracts, achieving interesting results for protection in stress conditions (OKURO et al., 2013; SILVA et al., 2018; SOUZA et al., 2018; TULINI et al., 2016; SILVA et al., 2019; MATOR-JR et al., 2019; HOLKEM; FAVARO-TRINADE, 2020). Our study design considered some limitations found in our previous research, which encapsulated probiotics showed a reduction of viability during long-term storage (Silva et al., 2018). Thus, the proposal of 
simultaneous encapsulation of probiotic and plant extracts could reduce the oxidative stress of probiotic cells due to the presence of antioxidants compounds in plant extracts.

The overall aims of this study were: (i) to evaluate the co-encapsulation of probiotics and guaraná extracts by complex coacervation, regarding its stability and release in simulated gastrointestinal fluids; (ii) to assist the necessity of encapsulation for incorporation of probiotics and guaraná extracts in yogurt drinks and peanut butter, verifying their quality parameters and viability of probiotics during storage; (iii) to develop a novel approach using vacuum biosorption for binding phenolics in probiotic cells, evaluating the release of phenolic compounds and probiotic survivability in simulated gastrointestinal fluids.

The potential probiotic strains used for co-encapsulation with guaraná extracts by complex coacervation were Lacticaseibacillus paracasei BGP-1 and Bifidobacterium animalis subsp. lactis BLC-1 from Sacco (Campinas, Brazil). To evaluate the vacuum biosorption of phenolic-rich extracts were investigated other strains, such as L. paracasei BGP-1, Lacticaseibacillus rhamnosus GG, and Lacticaseibacillus casei ATCC 393. These strains were available in the Laboratory of Professor Nitin Nitin at the University of California-Davis.

This thesis addresses the followed topics in chapters: Chapter 1 -Delivery systems for simultaneous intake of probiotics and plant extracts, Chapter 2 - The release study of microcapsules containing probiotics and guaraná extracts obtained by complex coacervation, Chapter 3 - Fortification of yogurt drink with microcapsules loaded with Lacticaseibacillus paracasei BGP-1 and guaraná seed extract, Chapter 4 - Development of functional peanut butter containing free and encapsulated probiotic and guaraná peel extract, Chapter 5 - Vacuum-assisted biosorption as a promising approach for simultaneous delivery of live probiotics and plantphenolic compounds, Chapter 6 - Loading of phenolic compounds in probiotic cells improves their survivability during in vitro digestion. Chapters 5 and 6 were investigated in collaboration with the research group of Professor Nitin Nitin at the University of California, Davis. Figure 1 illustrates the schematic representation of the present study. 
Figure 1 - Schematic representation of this study.

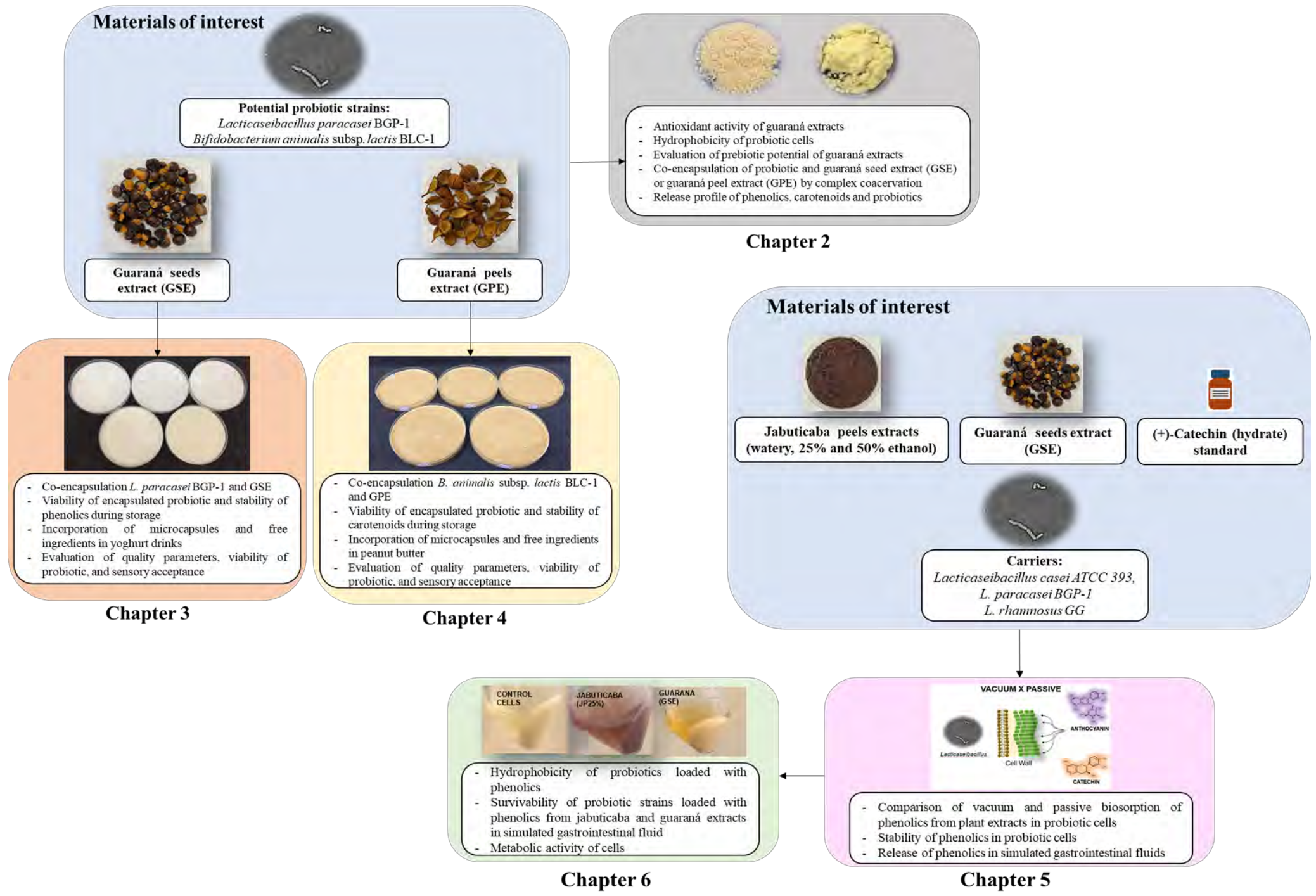

Reference: Own source. 


\section{REFERENCES}

ALTUN, H.K.; ERMUMCU, M.S.K.; KURKLU, N.S. Evaluation of dietary supplement, functional food and herbal medicine use by dietitians during the COVID-19 pandemic. Public Health Nutrition, v. 24, p. 861-869, 2020.

BERTAZZONI, E. et al. Probiotics and clinical effects: is the number what counts? Journal Of Chemotherapy, v. 25, p. 193-212, 2013.

BORRELLI, L. et al. Probiotic modulation of the microbiota-gut-brain axis and behaviour in zebrafish. Scientific reports, v. 6, 30046, 2016.

CROWE, K. M.; FRANCIS, C. Position of the Academy of Nutrition and Dietetics: Functional Foods. Journal of the Academy of Nutrition and Dietetics, v. 113, p. 1096-1103, 2013.

DANG, A.T.; MARSLAND, B.J. Microbes, metabolites, and the gut-lung axis. Mucosal Immunology, v. 12, n. 4, p. 843-850, 2019.

FAVARO-TRINDADE, C.S.; HEINEMANN, R.J.B.; PEDROSO, D.L. Review: Developments in probiotic encapsulation. Perspectives in Agriculture, Veterinary Science, Nutrition and Natural Resources, v.6, p.1-8, 2011.

GIBSON, G.R. et al. The International Scientific Association for Probiotics and Prebiotics (ISAPP) consensus statement on the definition and scope of prebiotics. Nature Reviews Gastroenterology \& Hepatology, v. 14, p. 491-502, 2017.

GRANATO, D.; NUNES, D.S.; BARBA, F.J. An integrated strategy between food chemistry, biology, nutrition,pharmacology, and statistics in the development of functional foods: A proposal. Trends in Food Science \& Technology, v. 62, p. 13-22, 2017.

HILL, C. et al. The International Scientific Association for Probiotics and Prebiotics consensus statement on the scope and appropriate use of the term probiotic. Nature Reviews Gastroenterology \& Hepatology, v. 11, p. 506-514, 2014. 
HOLKEM, A.T.; FAVARO-TRINDADE, C.S. Potential of solid lipid microparticles covered by the protein-polysaccharide complex for protection of probiotics and proanthocyanidin-rich cinnamon extract. Food Research International, v. 136, 109520, 2020.

IBGE. Produção de Jabuticaba no Brasil. 2017. Disponível em:

https://www.ibge.gov.br/explica/producao-agropecuaria/jabuticaba/br. Acesso em: 25 out. 2021

IBGE. Produção de Guaraná no Brasil. 2020. Disponível em:

https://www.ibge.gov.br/explica/producao-agropecuaria/guarana/br. Acesso em: 28 out. 2021

KENNEDY et al. Improved cognitive performance and mental fatigue following a multi-vitamin and mineral supplement with added guaraná (Paullinia cupana). Appetite, v. 50, p. 506-513, 2008

LENQUISTE, S.A. et al. Jaboticaba peel powder and jaboticaba peel aqueous extract reduces obesity, insulin resistance and hepatic fat accumulation in rats. Food Research International, v. 120, p. 880-887, 2019.

MA, G.; CHEN, Y. Polyphenol supplementation benefits human health via gut microbiota: a systematic review via meta-analysis. Journal of Functional Foods, v. 66, p. 103829, 2020.

MARINHO, J.F.U. et al. Probiotic and Synbiotic Sorbets Produced with Jussara (Euterpe edulis) Pulp: Evaluation Throughout the Storage Period and Effect of the Matrix on Probiotics Exposed to Simulated Gastrointestinal Fluids. Probiotics and Antimicrobial Proteins, v. 11, p. 264-272, 2019.

MARTEL, J. et al. Phytochemicals as Prebiotics and Biological Stress Inducers. Trends in Biochemical Sciences, v. 45, p. 462-471, 2020.

MASSA, N.M.L. et al. Effects of digested jabuticaba (Myrciaria jaboticaba (Vell.) Berg) byproduct on growth and metabolism of Lactobacillus and Bifidobacterium indicate prebiotic properties. LWT - Food Science and Technology, v. 131, p. 109766, 2020. 
MATOS-JR, F.E. et al. Evaluation of the viability and the preservation of the functionality of microencapsulated Lactobacillus paracasei BGP1 and Lactobacillus rhamnosus 64 in lipid particles coated by polymer electrostatic interaction. Journal of Functional Foods, v. 54, p. 98108, 2019.

NEILSON, A.P..; GOODRICH, K.M.; FERRUZZI, M.G. Bioavailability and Metabolism of Bioactive Compounds from Foods. Nutrition in the prevention and treatment of disease, $p$. 301-319, 2017.

OKURO, P.K. et al. Co-encapsulation of Lactobacillus acidophilus with inulin or polydextrose in solid lipid microparticles provides protection and improves stability. Food Research International, v.53, p. 96-103, 2013.

PEREIRA, E.P.R. et al. Oxidative stress in probiotic Petit Suisse: is the jabuticaba skin extract a potential option?. Food Research International, v. 81, p. 149-156, 2016.

PEREIRA, A.L.F.; MACIEL, T.C.; RODRIGUES, S. Probiotic beverage from cashew apple juice fermented with Lactobacillus casei. Food Research International, v. 44, n. 5, p. 12761283, 2011.

PINHO, L. S. et al. Guaraná (Paullinia cupana) by-product as a source of bioactive compounds and as a natural antioxidant for food applications. Journal of Processing and Preservation, 45, 2021.

ROZGA, M.; CHENG, F.W.; HANDU, D. Effects of Probiotics in Conditions or Infections Similar to COVID-19 on Health Outcomes: an evidence analysis center scoping review. Journal of the academy of nutrition and dietetics, v. 121, n. 9, p. 1841-1854, 2021.

SANTOS, P.D.F. et al. Microencapsulation of carotenoid-rich materials: a review. Food Research International, v. 147, p. 110571, 2021.

SILVA, M.P. et al. Semisweet chocolate as a vehicle for the probiotics Lactobacillus acidophilus LA3 and Bifidobacterium animalis subsp. lactis BLC1: Evaluation of chocolate stability and 
probiotic survival under in vitro simulated gastrointestinal conditions. LWT - Food Science and Technology, v. 75, p. 640-647, 2017.

SILVA, M.P. et al. Application of spray chilling and electrostatic interaction to produce lipid microparticles loaded with probiotics as an alternative to improve resistance under stress conditions. Food Hydrocolloids, v. 83, p. 109-117, 2018.

SILVA, M. P. et al. Production and characterization of solid lipid microparticles loaded with guaraná (Paullinia cupana) seed extract. Food Research International, v. 123, p. 144-152, 2019.

SOUZA, V.B., et al. Functional properties and encapsulation of a proanthocyanidinrich cinnamon extract (Cinnamomum zeylanicum) by complex coacervation using gelatin and different polysaccharides. Food Hydrocolloids, v. 77, p. 297-306, 2018.

TULINI, F. L. et al. Development of solid lipid microparticles loaded with a proanthocyanidinrich cinnamon extract (Cinnamomum zeylanicum): Potential for increasing antioxidant content in functional foods for diabetic population. Food Research International, v. 85, p. 10-18, 2016.

YONEKURA, L. et al. Bioavailability of catechins from guaraná (Paullinia cupana) and its effect on antioxidant enzymes and other oxidative stress markers in healthy human subjects. Food \& Function, v. 7, p. 2970-2978. 
2 CHAPTER 1 - DELIVERY SYSTEMS FOR SIMULTANEOUS INTAKE OF PROBIOTICS AND PLANT EXTRACTS 


\title{
2 CHAPTER 1 - DELIVERY SYSTEMS FOR SIMULTANEOUS INTAKE OF PROBIOTICS AND PLANT EXTRACTS
}

\begin{abstract}
Background: There is a current interest in healthy diets and supplements, indicating the relevance of novel delivery systems for bioactive compounds from plant extracts and probiotics. This simultaneous delivery can be prospective for health. In this sense, a further exploration of plantbased food to incorporate probiotics and some approaches to improve probiotic survivability, such as the choice of resistant probiotic strains or microencapsulation, is valuable.

Scope and approach: This review addresses a brief discussion about the role of phytochemicals from plants and probiotics in gut health, indicating the benefits of this association. Also, an overview of delivery systems used in recent studies is shown, considering their advantages for incorporation in food matrices.

Key Findings and Conclusions: Delivery systems containing phenolic compounds recovered from plants can reduce probiotic oxidative stress, improving probiotic survivability. However, investigating the beneficial concentration of bioactive compounds from plant extracts is relevant due to their antimicrobial potential. In addition, further clinical trials and toxicological studies of plant extracts are pertinent to ensure safety. Furthermore, a novel system delivery is the biosorption of plant extracts in live probiotic cells, excluding the need for polymers to protect them and delivering lower concentrations of phenolics. Thus, the recovery of bioactive compounds from plants emerges as an alternative to providing multiple compounds with antioxidant potential, increasing the preservation of probiotics and allowing the fortification or enrichment of food matrices.
\end{abstract}

Keywords: probiotics, plants, phenolics, microencapsulation, biosorption, carriers, functional foods. 


\subsection{INTRODUCTION}

There is a trend of eating habits shifting toward health and wellness, launching new food products and supplements on the market. In this sense, probiotics and phenolic compounds are widely searched for achieving varied health benefits. In addition, it is undeniable that polyphenols' antimicrobial and antioxidant properties positively impact gut health, contributing to balancing the microbiota by increasing the proliferation of Lactobacillus and Bifidobacterium (MA; CHEN, 2020; VALDÉS et al., 2015). Plant polyphenols were considered emerging prebiotics since most of them reach the colon for biotransformation of gut microbiota, improving their bioavailability (GIBSON et al., 2017; VALDÉS et al., 2015). However, there are some interesting issues to discuss, such as (i) could the simultaneous intake of probiotics and plant extracts improve the survivability of probiotics by their antioxidant potential during digestion?; (ii) what is the influence of other phytochemicals from plant extracts in gut health?; (iii) what is the role of phenolics during the adhesion of probiotics in the gut?

Some food matrices protect bioactive compounds and probiotics, extending the probiotic viability and improving the preservation of the bioactive compounds. For instance, lipid-based food showed the potential to incorporate probiotics, such as peanut butter, table spread containing milk fat and chocolate (KLU; CHEN, 2015; SANTOS et al., 2020; SILVA et al., 2017). However, microencapsulation can be an alternative to increasing the protection even for products with high viability of probiotics during the storage since a considerable amount of probiotics are required to reach the gut for benefits.

Microencapsulation technology is explored for packing bioactive compounds and the combination of carriers may control their release in the target (COMUNIAN; FAVAROTRINDADE, 2016). Concerning the first studies about simultaneous encapsulation of probiotic and bioactive compounds, the combination of carbohydrate-based prebiotics was investigated to improve the probiotic viability and enhance the microparticles (OKURO et al., 2013; IYER; KAILASAPATHY, 2005). Also, another classic approach is the combination of fruit juices and probiotics, which can be previously fermented or not, for microencapsulation by spray-drying (ANEKELLA; ORSAL, 2013; PEREIRA; MACIEL; RODRIGUES, 2011). In this regard, producing a powder containing phytochemicals and probiotics is versatile, offering new products for the functional market. However, spray drying may cause thermal stress of probiotics, reducing 
their viability. In this way, the production of alginate beads and coacervates using polymers are two convenient and mild processes for the entrapment of probiotics and plant extracts (CHAIKHAM, 2015; SHINDE; SUN-WATERHOUSE; BROOKS, 2013; HOLKEM; FAVAROTRINDADE, 2020). Another advantage of the production of microparticles is the fortification of food matrices, increasing the probiotic viability over the storage of this product and providing extra bioactive compounds (KRASAEKOOPT; WATCHARAPOKA, 2014; CHAIKHAM, 2015). However, applying these systems in foods can change the sensory and textural properties, hindering its acceptance. For this reason, the development of novel delivery systems is quite relevant.

A promising technique is biosorption, which can utilize the microorganisms' cells for binding some bioactive compounds. The technological principle of the biosorption of bioactive compounds in cells is based on their binding capacity, considering the affinity of bioactive compounds with the cell wall. For example, other studies reported that lactic acid bacteria could bind heavy metals from water (IBRAHIM et al., 2006) and accumulated minerals in the cells (MÖRSCHBÄCHER et al., 2018). However, the modification of the probiotic cell wall for binding polyphenols may affect the membrane integrity. For this reason, other approaches like vacuum could increase the binding of bioactive compounds in cells maintain their viability (YOUNG; DEA; NITIN, 2017; SILVA et al., reviewing). One of the advantages of this technology is the small size of probiotic cells, which probably maintains the texture of food matrices. Although if the microorganism remains viable, some sensory changes may occur during the storage of the product.

Thus, this review aimed (i) to briefly discuss the relevance of probiotics and plant extracts separately and combined for health; (ii) to critically discuss the influence of phenolic compounds to enhance the probiotic adhesion in the gut; (iii) to evaluate the significant advances in simultaneous delivery systems.

\subsection{PHYTOCHEMICALS FROM PLANTS EXTRACTS IN HUMAN HEALTH}

\subsubsection{Phenolic compounds-rich plant extracts in human health}


There is great interest in natural substances with antioxidants properties, which can reduce or inhibit oxidative stress. Stress oxidative is defined as an imbalance between the antioxidant defense system and reactive oxygen species (ROS) (GRZESIK et al., 2018). Oxidative stress causes cell death and tissue damage, which can be observed in cardiovascular diseases, diabetes, cancer and aging (TREML; SMEJKAL, 2016). In this way, phenolic compounds found in plants stand out by their antioxidant potential, displaying several health benefits, such as reducing oxidative stress markers and modulation of gut microbiota, as shown in Table 1.

Phenolic compounds are defined as secondary metabolites of plants related to the defense against ultraviolet radiation (UV) or pathogen contamination (MANACH et al., 2004). This class of phytochemicals is widely distributed in plants, represented by more than 8000 compounds, classified as simple phenol and polyphenols, depending on the number of phenol units in the molecule (KING; YOUNG, 1999; HO, 1992). The chemical structure of polyphenols shows aromatic rings bound with hydroxyl groups. Furthermore, phenolic compounds prevent some degenerative diseases, such as cancer and cardiovascular diseases (MANACH et al., 2004).

Among polyphenols, catechins or flavan-3-ols are often present in plants, green and black tea, wine, beer and cocoa, displaying versatile antioxidant properties, offering an alternative for therapeutical purposes. Therefore, novel sources of polyphenols have been explored, such as guaraná seeds, which showed anti-hyperglycemic and anti-obesity potentials by affecting glucose metabolism and inhibiting the lipase (YONEKURA et al. al., 2016; SILVA et al., 2017; SILVA et al., 2019). A clinical trial with a daily dose of guaraná, containing total phenolic content of 455 mg Acid Gallic Equivalent - AGE, $90 \mathrm{mg}$ of catechins and $60 \mathrm{mg}$ of epicatechins, enhanced the oxidative stress markers of patients (YONEKURA et al., 2016). Another study reported that guaraná seed powder rich in caffeine (approximately $34.2 \mathrm{mg}$ of caffeine/g, $3.8 \mathrm{mg}$ of catechin/g and $4 \mathrm{mg}$ of epicatechin/g) improved the redox homeostasis, whereas reduced the proliferation of Lactobacillus present in the gut microbiota of rats (SILVEIRA et al., 2018). However, the combination of low doses of caffeine (20 mg/kg) and epigallocatechin-3-gallate (40 mg/kg), using the ratio present in green tea, was efficient to decrease the Firmicutes and increase the abundance of Bifidobacterium in rats (ZHU et al., 2021). Thus, plant extracts' chemical profile and concentration significantly influence gut modulation, which justifies these variations between the results. 
However, catechins are highly susceptible to oxidation by the presence of light, high temperature and an alkaline environment (GRZESIK et al., 2018). In this sense, microencapsulation is widely investigated to protect phenolic compounds (HOLKEM; FAVAROTRINDADE, 2020; SILVA et al., 2019; WU et al., 2020). Nevertheless, few studies verified the preservation of phenolic compounds' functionality after encapsulation. In this way, Wu et al. (2020) evaluated the effect of different encapsulating materials used for microencapsulation of blueberry extract in the release of bioactive compounds and in vitro modulation of gut microbiota. These authors reported that gelatin and soy protein isolate effectively delayed the anthocyanins release in simulated gastrointestinal fluids and changed the microbial composition during fermentation. Another study performed a clinical trial administrating encapsulated grape pomace for healthy subjects for 4-weeks, reporting a reduction of markers related to cardiovascular incidents (ANNUNZIATA et al., 2019). Although these studies demonstrated that microencapsulation technology preserved the benefits of phenolic compounds, these findings depend on the technique used and encapsulating materials. In this context, the performance of in vivo studies for encapsulated bioactive compounds is highly recommended to broaden their understanding and actual efficacy. 
Table 1 - Impact of phenolic compounds from plants in human health.

\begin{tabular}{|c|c|c|c|}
\hline Source of phenolics & Design of the study & Main Outcomes & Reference \\
\hline $\begin{array}{l}\text { Plant extracts from Porphyra } \\
\text { umbilicalis, Melissa officinalis L. and } \\
\text { Emblica officinalis Gaertn }\end{array}$ & $\begin{array}{l}\text { In vivo test using obese } \\
\text { mice }\end{array}$ & $\begin{array}{l}\text { The administration of plant extracts for two weeks in obese mice } \\
\text { affected their gut microbiota, markers of lipid metabolism and } \\
\text { caecum metabolome }\end{array}$ & Brochot et al. (2019) \\
\hline $\begin{array}{l}\text { Gastro-resistant capsules containing } \\
\text { grape pomace extract (Taurisolo } ®)\end{array}$ & $\begin{array}{l}\text { In vivo test using } 20 \\
\text { healthy subjects }\end{array}$ & $\begin{array}{l}\text { Four-week treatment with two capsules of Taurisolo }{ }^{\circledR} \text { decreased the } \\
\text { serum levels of trimethylamine N-oxide (a biomarker of } \\
\text { cardiovascular disease) }\end{array}$ & Annunziata et al. (2019) \\
\hline Guaraná seed powder & $\begin{array}{l}\text { In vivo test using } 12 \\
\text { healthy } \\
\text { subjects }\end{array}$ & $\begin{array}{l}\text { Two-week daily administration of } 3 \mathrm{~g} \text { of guaraná seed powder } \\
\text { improved oxidative stress markers due to the bioavailable catechins }\end{array}$ & Yonekura et al. (2016) \\
\hline $\begin{array}{l}\text { Sweet pepper (Capsicum annuum) } \\
\text { extract }\end{array}$ & In vivo test using mice & $\begin{array}{l}\text { Six-week treatment with sweet pepper (Capsicum anпиит) extract } \\
\text { containing high content of polyphenols, carotenoids, and capsinoids, } \\
\text { improved the high-fat diet-induced in mice and other biomarkers } \\
\text { associating these findings with gut microbiota modulation }\end{array}$ & Sinisgalli et al., 2020 \\
\hline $\begin{array}{l}\text { Green tea phenolics and oxidized tea } \\
\text { phenolics }\end{array}$ & In vivo test using mice & $\begin{array}{l}\text { Green tea phenolics and oxidized tea phenolics maintained the } \\
\text { benefit of body weight management during treatment of } 12 \text {-week. } \\
\text { Also, both showed a similar modulatory effect }\end{array}$ & Liu et al. (2022) \\
\hline Anthocyanins-rich extract of açai fruit & In vivo test using mice & $\begin{array}{l}\text { 14-week treatment associated with a high-fat diet and } \\
\text { supplementation of açai extract changed gut microbiota, maintaining } \\
\text { the abundance of Bacteroidetes and reducing Firmicutes. Also, açai } \\
\text { extract attenuated high-fat diet-induced obesity and others }\end{array}$ & Song et al. (2021) \\
\hline
\end{tabular}

Reference: Own source. 


\subsubsection{Potential of other phytochemicals from plants in gut modulation}

Although most studies attribute the benefit of modulating the intestinal microbiota to phenolic compounds, current investigations have shown that other phytochemicals also contribute to this regard. Recent studies evaluated the potential of chlorophyll and carotenoids as discussed briefly sequentially.

Chlorophyll is the green pigment found in plants essential for photosynthesis. In addition, chlorophylls are tetrapyrrole derivatives, being unstable to food processing (ROCA; CHEN; PÉREZ-GALVEZ, 2016). Some studies evaluated the potential of chlorophyll for health. For instance, supplementation chlorophyll-rich spinach extract in mice fed with a high-fat diet during 13-weeks attenuated body weight gain, inflammation, glucose intolerance, and modulated gut microbiota (LI et al., 2019). Concerning the action mechanisms, in vitro digestion of chlorophyllrich spinach extract showed their biotransformation to pheophytins, increasing the production of short-chain fatty acids (SCFA) and supporting the beneficial gut microbiota (LI et al., 2021). However, these authors highlighted the need for further studies considering the effect of a varied diet to clarify the interplay of chlorophyll and gut microbiota.

Carotenoids are lipophilic pigments responsible for yellow, orange, and red in plants, such as tomato, carrot, papaya, etc. Despite the structural diversity due to the double bond centrally conjugated, this characteristic makes it more sensitive to oxidation and isomerization (RODRIGUEZ-AMAYA, 2019). Concerning the effect of carotenoids in gut microbiota, some recent studies assessed pure compounds, displaying the potential of carotenoids to modulate gut microbiota. In this way, a clinical trial administrated encapsulated lycopene for moderately obese adults for one month, enhancing gut microbiota by reducing Bacteroides and increasing the abundance of Bifidobacterium (WIESE et al., 2019). Another study reported that fucoxanthin, a carotenoid found in brown algae and diatoms, attenuated gut dysbiosis in mice fed with a high-fat diet, increasing the population of Bifidobacterium and Lactobacillus whereas decreasing the abundance of obesity-promoting bacteria (SUN et al., 2020). In addition, vitamin A improves the intestinal epithelial barrier function in cell culture (MEDEIROS et al., 2018; HE et al., 2019), evidencing the promising role of carotenoids for gut health. 
Carotenoids from plant extracts showed antimicrobial activity against Helicobacter pylori, which could reduce the abundance of this pathogen in the digestive system (MOLNÁR et al., 2005). Furthermore, in vitro digestion of probiotics and raw or fried tomatoes indicated the protective effect of tomato maintaining probiotic viability, whereas probiotics reduced the bioaccessibility of the antioxidants (GARCÍA-HERNÁNDEZ et al., 2018). Thus, carotenoids could enhance the balance of gut microbiota by their antimicrobial and antioxidant potential, but their mechanisms remain unexplored, especially for carotenoid-rich plant extracts.

Another review provided insights into the role of different phytochemicals in modulating the gut microbiota (DINGEO et al., 2020). However, considering the numerous phytochemicals present in plants, many bioactive compounds have yet to be investigated. In addition, the understanding of the action mechanisms of these phytochemicals in the gut has not been fully elucidated, demonstrating the need for further studies.

\subsection{SUPPLEMENTATION OF PROBIOTICS FOR GUT MODULATION}

Probiotics can be defined as live microorganisms that improve the host's health when administered adequately (FAO/WHO, 2002; HILL et al., 2014). In addition, they create a favorable environment for the intestine through their mechanisms of action, which will depend on various factors, such as the type of strain used, the host, and food. Among the main benefits of these microorganisms, standing out the maintenance of healthy digestive and immune systems (HILL et al., 2014).

Several studies reported that the composition of gut microbiota influences human health. Dysbiosis can be defined as an alteration of the gut microbiota, which is correlated with gut inflammation and some diseases (SERRA; ALMEIDA; DINIS, 2018). Recent studies have shown that the benefits of probiotics extend beyond the gastrointestinal tract, playing a bidirectional relationship with the central nervous system and lung, known as gut-brain and gut-lung axes, respectively (CRYAN; DINAN, 2012; DANG; MARSLAND, 2019). In this sense, dysbiosis can affect both axes, causing some neurological, respiratory, and intestinal diseases. However, several studies evaluated the gut-brain axis, while the gut-lung axis still needs further investigation. 
In relation to the gut-brain axis, the modulation of gut microbiota could prevent some neurological diseases, such as schizophrenia, autism, mood disorders and improvement of emotional problems of patients with fibromyalgia (CRYAN; DINAN, 2012; DINAN; BORRE; CRYAN, 2014; MANGIOLA et al., 2016; ROMAN et al., 2018). In addition to the supplementation of probiotics, recent studies have demonstrated the potential for modulating the gut microbiota using polyphenols to prevent and treat neurological disorders (SERRA; ALMEIDA; DINIS, 2018).

Some studies verified the beneficial efficacy of probiotic supplementation to respiratory diseases, depending on the strains and dosage (ANAN; MANDE, 2018). In this regard, the recovery of patients infected with SARS-COV-2 could be improved with some nutritional strategies, using probiotics, prebiotics, and functional foods, aiming to modulate gut microbiota (DHAR; MOHANTY, 2020). However, there is high variability among the studies of probiotics supplementation for patients with Covid-19, which did not confirm a direct correlation in improving their clinical state (ROZGA; CHENG; HANDU, 2021).

Bowel colonization begins during childbirth by the baby's contact with the mother's reproductive system and the environment. Furthermore, breast milk also contributes to the colonization and establishment of the microbiota. Some studies have already shown that human milk has some prebiotics in its composition (COPPA et al., 2006). In addition, the insertion of solid food containing carbohydrates and fiber may diversify the child's microbiota. However, aging drastically alters the microbiota composition, reducing the counts of beneficial species and causing some diseases such as inflammatory bowel disease (KUMAR; BABAEI; NIELSEN, 2016). In this way, probiotic supplementation for the elderly can be an alternative to improve life expectancy and reduce hospitalization costs.

The main action mechanisms of probiotics in the gut are: (i) the reduction of intestinal permeability due to the strengthening of the mucus layer and tight junctions between enterocytes; (ii) some probiotic strains release bacteriocins against bacteria, fungi, and viruses, and outcompeting other microbes; (iii) antimicrobial substances produced by probiotics, such as lactic and acetic acid, which have an inhibitory effect on Gram-negative bacteria; (iv) some probiotics increase energy harvest, producing short-chain fatty acids (SCFA), vitamins, etc.; (v) some probiotics attenuates the inflammation (BERMUDEZ-BRITO et al., 2012; HALLORAN; 
UNDERWOOD, 2019). Thus, probiotics act in different ways, interfering with the adhesion of pathogens to the intestinal mucosa. Figure 2 shows the positive influence of simultaneous intake of probiotics and phytochemicals on human health.

\subsection{BENEFICIAL ASSOCIATION OF PROBIOTICS AND PHENOLIC COMPOUNDS}

Gut microbiota plays a fundamental role in maintaining the host health, directly influencing its composition and operation. Feeding can interfere and complement the microbiota resident; thus, the probiotic microorganisms carried in food will temporarily be part of the community (DERRIEN; VLIEG, 2015). According to Valdés et al. (2015), there is a bidirectional and synergistic interaction between phenolic compounds and gut microbiota. Furthermore, the definition of prebiotics is relevant for understanding the interactions between probiotics and phenolic compounds since most of them reach the colon for biotransformation. Prebiotics are substrates selectively used by host microorganisms that confer health benefits (GIBSON et al., 2017).

Currently, several works have been investigating the in vitro prebiotic potential of phenolics present in plants. For example, the effect of anthocyanin-rich extracts from the plum peel, Italian grape, and elderberry in the multiplication of probiotics demonstrated the prebiotic potential of anthocyanins and the more significant antioxidant activity of formulation containing elderberry extracts and probiotics compared to the extract alone (COMAN et al., 2018). Furthermore, Hu et al. (2018) reported that mango juice and its extracts positively influence the multiplication of probiotics. In addition, gallic acid, the major phenolic compound in mango, contributed significantly to the proliferation of probiotics (HU et al., 2018). However, despite promising results, these authors highlight the need for in vivo study for understanding the modulation of the intestinal microbiota. 
Figure 2 - Promising benefits and biological properties of phytochemicals and probiotics on human health.

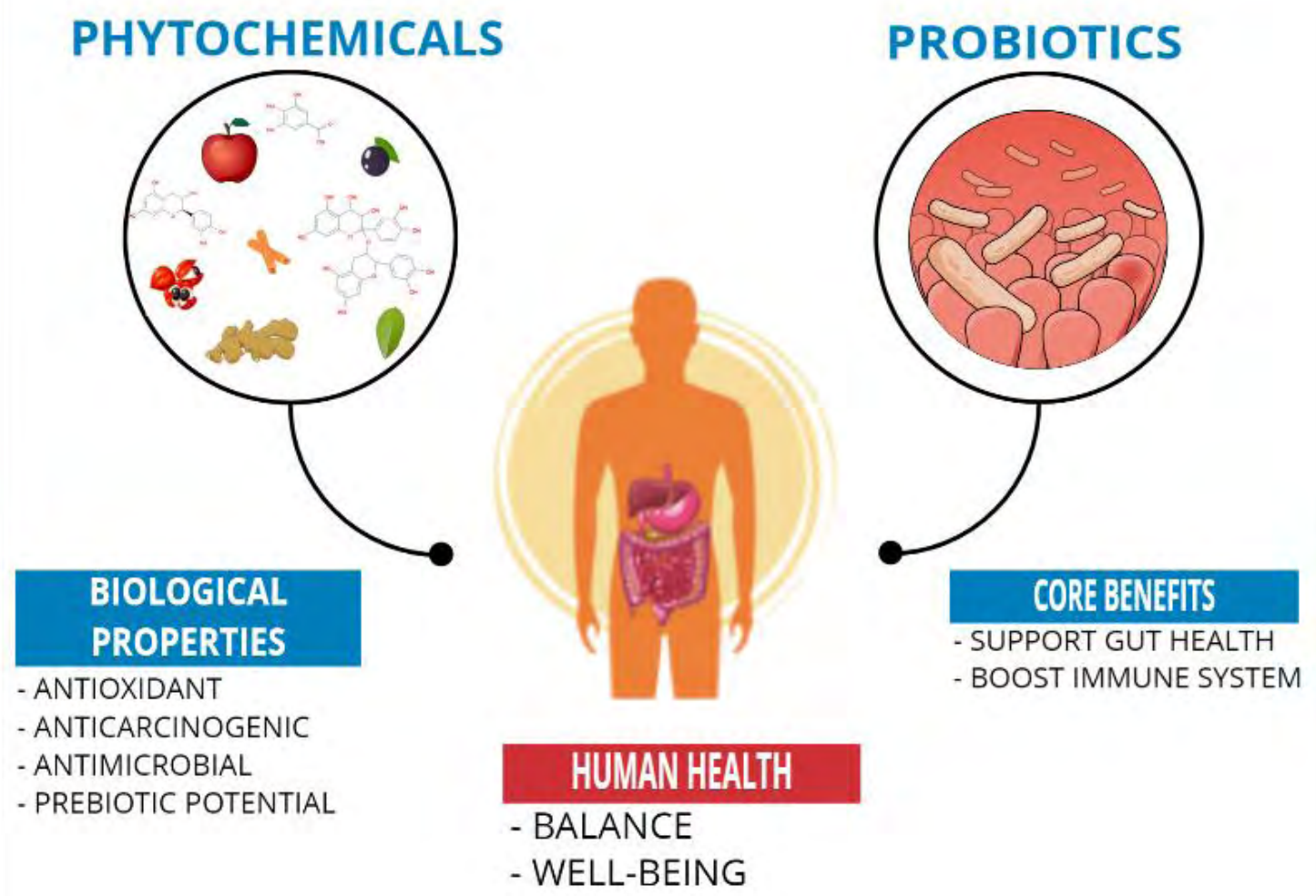

Reference: Own source.

Concerning the beneficial effects of the association of probiotics and polyphenols in food matrices, Vendrame et al. (2011) verified the positive impact of six-week consuming a drink of blueberry ( $25 \mathrm{~g}$ of wild blueberry powder in $250 \mathrm{~mL}$ of water) using healthy patients to modulate the intestinal microbiota, reporting the increase in populations of Bifidobacterium spp. Another in vivo study administered milk fermented containing whey protein, Bifidobacterium animalis (BB12), and pomegranate for 6-week for mice, providing a restored gut microbiota and preserving acute exercised mice (CHAVES et al., 2018).

There is a trend to valorize phenolic compounds-rich food by-products as functional ingredients, allowing sustainable foods development. In this sense, an innovative ingredient was produced from pumpkin's by-products loaded with Lacticaseibacillus casei ATCC-393, former Lactobacillus casei ATCC-393, for incorporation in beverages, recovering between $35 \%$ to $80 \%$ of probiotics after in vitro digestion (GENEVOIS; FLORES; ESCALADA, 2016). Likewise, acerola by-product associated with Bifidobacterium longum BB-46 showed a positive effect on 
gut microbiota in Simulator of Human Intestinal Microbial Ecosystem (SHIME®), increasing the production of SCFA (BIANCHI et al., 2019).

In addition, incorporating probiotics in food matrices containing polyphenols, which have recognized antioxidant activity, could prevent the adverse effects of exposure to oxygen during the multiplication of probiotics or in storage (GAUDREAU et al., 2013). Furthermore, polyphenols can donate electrons for free radicals, stabilize the free radicals, and discontinue oxidative stress (CORY et al., 2018). Some examples of probiotic incorporation in polyphenolsrich food matrices were evaluated by our research group, such as semisweet chocolate and jussara sorbets, which may have contributed to maintaining the viability of probiotics during the storage period (MARINHO et al., 2019; SILVA et al., 2017). Therefore, the combination of foods rich in phenolic compounds and probiotics can be an alternative to enhance the viability of probiotics, extending the health benefits and diversifying the available food options present in the market.

\subsubsection{Influence of phenolic compounds for probiotic adhesion in the gut}

Another recurring discussion is about the influence of phenolic compounds to enhance the adhesion of probiotics into the intestinal mucosa. As known, probiotics adhere to the intestinal epithelium cells followed by the temporary colonization to exert health benefits to the host. The adhesion mechanism of probiotic strains depends on cells' interacting surface properties and composition (PÉREZ et al., 1998). In this sense, some assays to evaluate the potential of adhesion of probiotic strains apply simplified models, such as mucin and hydrocarbons affinity, besides the in vitro cells models, such as the Caco-2 and HT-29 human epithelial cells. Furthermore, proteomic analysis is a potential approach that allows the comprehension of the mechanisms involved during adherence of probiotics in the presence of phenolic compounds.

Few studies verified if the association of probiotic and phenolic compounds may change the cell surface hydrophobicity. For example, Santos et al. (2019) reported that Lactobacillus strains combined with quercetin $(512$ - $1024 \mu \mathrm{g} / \mathrm{mL})$ increased between 2 to 4 -fold the hydrophobicity of cells by the affinity with n-hexadecane. On the other hand, resveratrol did not affect the hydrophobicity of Lactobacillus strains, demonstrating the complexity of these interactions (SANTOS et al., 2019). 
Proteins present on the surface of the probiotic cell wall play an essential role in the adhesion capacity to epithelial cells. In addition, the gastrointestinal environment, such as $\mathrm{pH}$, influences the binding of these proteins during adhesion (BERGONZELLI et al., 2006). In this way, some phenolic compounds found in plants, such as resveratrol, tannic acid, caffeic acid, and ferulic acid, were investigated regarding the adhesion of Lactobacillus acidophilus NCFM to the HT-29 cells and mucin (CELEBIOGLU et al., 2018). Proteome analysis of bacterial surface treated with resveratrol indicated the increment of pyruvate kinase, elongation factor $\mathrm{P}$, and ribosomal proteins, which may promote the adhesion (CELEBIOGLU et al., 2018). Also, these authors suggested that phenolic compounds influence the synthesis of specific proteins control the release of proteins, that regulate the adhesion ability of probiotics.

Shinde et al. (2015) evaluated the effect of polyphenols on the adhesion of probiotics to hydrophilic tissue culture microtiter plates using crystal violet. Water apple skin extracts enhanced around 1.4-fold the attachment of probiotic, compared with the ethanolic extract. Although purified phenolic compounds increased the adhesion of probiotics, such as rutin, which presented a similar performance to ethanolic apple skin extract, the influence of water extract was superior. Thus, the chemical profile of phenolic compounds found in apple skin extracts can explain these differences between water and ethanolic extracts.

A similar study verified that the application of apple skin extract increased the adhesion of Lactobacillus gasseri R and Lacticaseibacillus casei FMP, former Lactobacillus casei, to the intestinal epithelial cells Caco-2 and HT29-MTX (VOLSTATOVA et al., 2017). In contrast, lowphenolic compounds apple pulp extract reduced the probiotic adhesion (VOLSTATOVA et al., 2017). These authors suggested that hydroxyl groups found in chemical structures of phenolic compounds increased the adhesion of probiotic cells by protein-protein interactions, besides the effect of specific phenolic compounds, such as quercetin, that enhanced the adhesion of L. gasseri R.

Another study evaluated the influence of acerola, mango, orange, and passion fruit byproduct water extracts to improve the adhesion of L. rhamnosus GG and Streptococcus thermophilus TH-4 (ALBUQUERQUE et al., 2019). That study verified through Principal Components Analysis (PCA) that antioxidant properties of all extracts favored the adherence of $L$. rhamnosus GG to the Caco-2 cells. 
The adhesion capacity of probiotics depends on the strains and chemical structure of the phenolic compound and the in vitro model system, Caco-2 and HT-29 human epithelial cells, which may affect the response (BUSTOS et al., 2012). In addition, a high concentration of phenolic compounds may not positively influence the adhesion of probiotics into Caco-2 cells. In this way, Llano et al. (2017) tested the influence of catechin concentrations at $50 \mu \mathrm{M}$ and $250 \mu \mathrm{M}$ to enhance the attachment of probiotic strains, demonstrating that lower concentration was more efficient. Thus, there is a specific limit of phenolic compounds concentration, which from there, the effect can be reversed.

On the other hand, it is widely known that rich-phenolic compounds in plant extracts may present antimicrobial activity against pathogens microorganisms. This property also affects the adherence of pathogens in the gut to balance the gut microbiota, as previously mentioned. In this way, Zhao and Shah (2015) reported that tea and soybean extracts avoided at least $56 \%$ of the attachment of pathogens bacteria to the Caco-2 cells. They suggested that macromolecules presented in plant extracts could act similarly to the adhesion, binding epithelial cells. Peres et al. (2015) reported a synergistic effect of probiotic cells and oleuropein or hydroxytyrosol on Escherichia coli adhesion to Caco-2 cells by competition. Although this association reduced the adhesion of probiotics to Caco-2 cells, phenolic compounds probably bound pathogenic cell surface, decreasing its adhesivity. Another study noticed that incubation of only catechin and 3,4dihydroxyphenylacetic did not influence the adhesion of E. coli in Caco-2 cells (LLANO et al., 2017). In contrast, a synergistic effect was verified by associating phenolic compounds and probiotics (LLANO et al., 2017). Also, these authors demonstrated that phenolic compounds enhanced the adhesion of probiotics in Caco- 2 cells, consequently reducing the attachment of $E$. coli.

Therefore, these studies that used mainly in vitro cells showed evidence that phenolic compounds increase the adhesion capacity of probiotic cells into the gut, as summarized in Figure 3. However, there is a lack of studies that approach the correlation and prediction of potential associations between probiotic strains and specific phenolic compounds to increase the adhesion. Besides that, complementary clinical studies are fundamentals to confirm these findings. 
Figure 3 - Some possible adhesion mechanisms of phenolic compounds that positively influence the probiotic (gray rod-shaped bacteria) adhesion in the gut.

\section{ROLE OF PHENOLICS FOR PROBIOTIC ADHESION IN THE GUT}

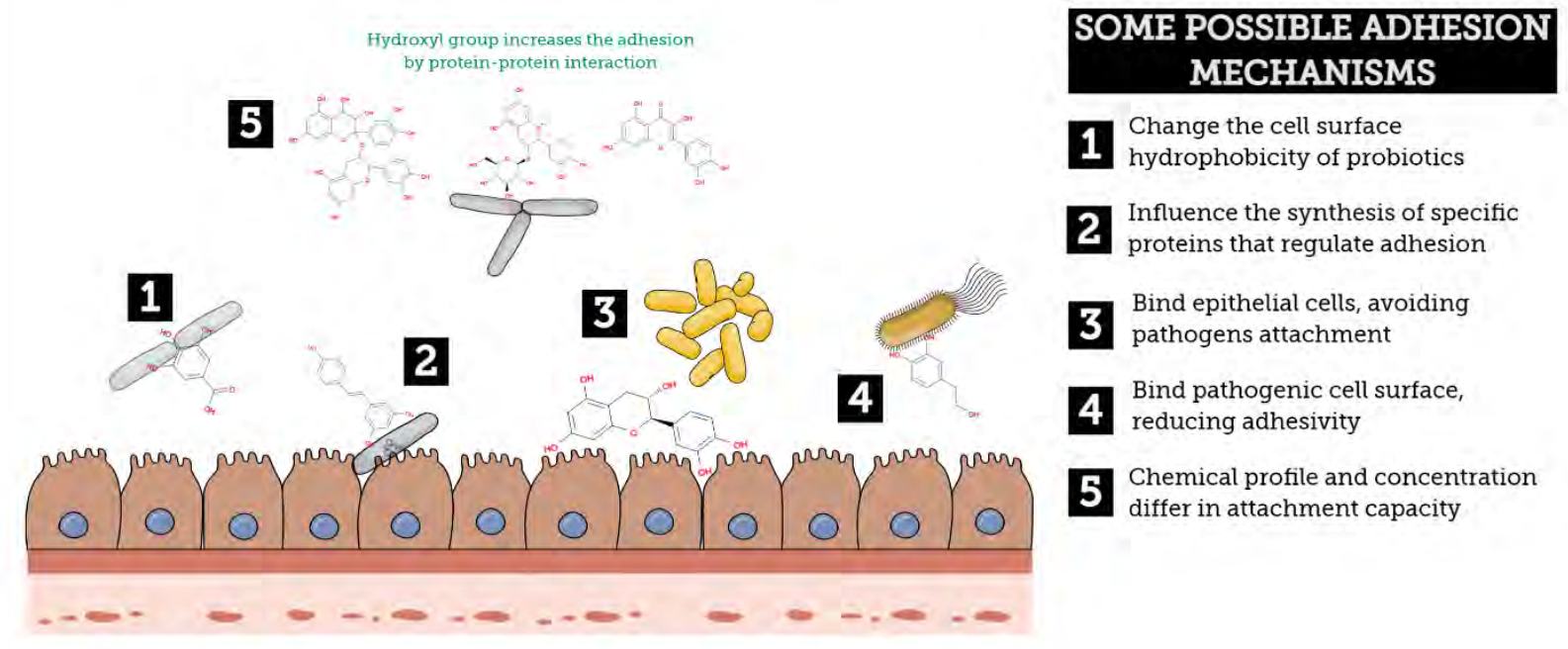

Reference: Own source.

\subsection{DELIVERY SYSTEMS}

Microencapsulation is a strategy used by industries and research centers to develop functional supplements, ingredients and foods. In this sense, bioactive compounds are sensitive to some conditions that can be used during food processing, such as high temperature and presence of oxygen and the digestive process due to the low $\mathrm{pH}$ in the stomach and the presence of bile salts. Thus, microencapsulation is a technology that aims to protect bioactive compounds from these deleterious conditions (FÁVARO-TRINDADE; PINHO; ROCHA, 2008). Also, the design study for controlled release microcapsule is relevant and based on the combination of food-grade encapsulating materials. Therefore, the development of an efficient microcapsule requires at least three planning steps: (i) understanding the biological and physicochemical properties of the bioactive compounds that will be microencapsulated; (ii) the selection of the encapsulation method and encapsulating materials, considering the costs and the adequacy of microcapsules in the food matrix; (iii) after incorporation of microcapsules in a food matrix, it is necessary to evaluate the quality parameters and the release of bioactive compounds at least in simulated gastrointestinal conditions. Thus, these concepts are discussed in the next section. 


\subsubsection{Microencapsulation}

Microencapsulation techniques of bioactive compounds are based on physical, chemical and physical-chemical methods (COMUNIAN; FAVARO-TRINDADE, 2016). Physical methods include spray drying, spray chilling, spray coating, and encapsulation processes using fluids supercritical and microfluidic systems. Polymerization is a technique based on the chemical method. The physical-chemical methods allow the microencapsulation by complex coacervation, liposomes, micelles, emulsions, among others. This review will briefly discuss spray drying, spray chilling, and complex coacervation, considering their potential for protecting probiotics and bioactive compounds.

\subsubsection{Atomization processes}

Spray drying and spray chilling are based on the atomization of the mixture containing the protective carrier and bioactive compounds. The dispersion or emulsion is pumped into the equipment and atomized in a chamber, differing by the air temperature, using hot air for spray drying and cold air for spray chilling (OKURO; MATOS JR; FÁVARO -TRINDADE, 2013).

Spray drying is already used in commercial products due to its advantages, such as speed and low cost of production. However, heating can be harmful to some probiotic strains, causing probiotic death by membrane damage (PÁEZ et al., 2013). In this way, most studies evaluate the effect of temperature and different carriers in probiotic survival. Some examples of carriers widely used for spray drying are maltodextrin, gum Arabic, and Whey Protein Isolate (WPI).

The encapsulation by spray chilling uses previously melted vegetable fat for mixing the bioactive compounds before the atomization with cold air. In general, lipid matrices with a melting point between $32-45^{\circ} \mathrm{C}$ are selected for spray chilling (BARBOSA-CÁNOVAS et al., 2005). However, there are some options to diversify carriers for spray chilling, such as the application of $\kappa$-carrageenan and other thermogels (CHAMPAGNE; FUSTER, 2007). 
Microparticles produced by spray drying and spray chilling can be classified as matrices, as the content of the bioactive material is present throughout the structure, including the surface (Figure 4). Between these processes, spray chilling showed promising results for protecting probiotics, which can be justified with the gradual release in the gut since lipid digestion effectively occurs in the intestine (FÁVARO-TRINDADE; OKURO; MATOS JR, 2015). In addition, several bioactive compounds were encapsulated using this technique, such as cinnamon extract (TULINI et al., 2016), lycopene (PELISSARI et al., 2016), guaraná seed extract (SILVA et al., 2019), probiotics (OKURO et al., 2013; SILVA et al., 2018), etc.

\subsubsection{Complex coacervation}

Complex coacervation is a technique based on the electrostatic interaction of oppositely charged biopolymers to form microcapsules (ERATTE et al. 2018; GOUIN, 2004). According to Turgeon, Schimitt and Sanchez (2007), the electrostatic interaction of biopolymers is an essential physicochemical phenomenon for several biological processes, such as antigen-antibody reactions and protein transcription. Another example related to electrostatic interaction is the sensation of astringency when we consume some products, such as coffee or green bananas. Polyphenols in the food bind the proteins present in the taste, thus, forming aggregates that cause loss of taste lubrication (GREEN, 1993; CARVALHO et al., 2006).

Complex coacervation starts with the suspension of the bioactive compounds in the core material, which usually is a lipid or one of the polymers (protein), or an emulsion can be prepared. After, the other polymer (polysaccharide) is added to the mixture, and the $\mathrm{pH}$ is adjusted for the colloids present opposite charges. As illustrated in Figure 4, this encapsulation method produces true microcapsules, also called reservoir-type microcapsules, since bioactive compounds are covered by a double wall (SANTOS et al., 2015). Some encapsulation parameters, such as $\mathrm{pH}$, ionic concentration and ratio between matrix and bioactive compounds, affect the microcapsule size (VOS et al., 2010). The microcapsules obtained by complex coacervation are moist, making it challenging to apply on an industrial scale. However, these microcapsules can be dried to prevent deterioration and loss of functionality during storage (SILVA et al., 2016). In general, drying methods most used are spray drying, lyophilization and fluidized bed. 
Figure 4 - Some examples of delivery systems for simultaneous intake of probiotics and bioactive compounds from plant extracts.

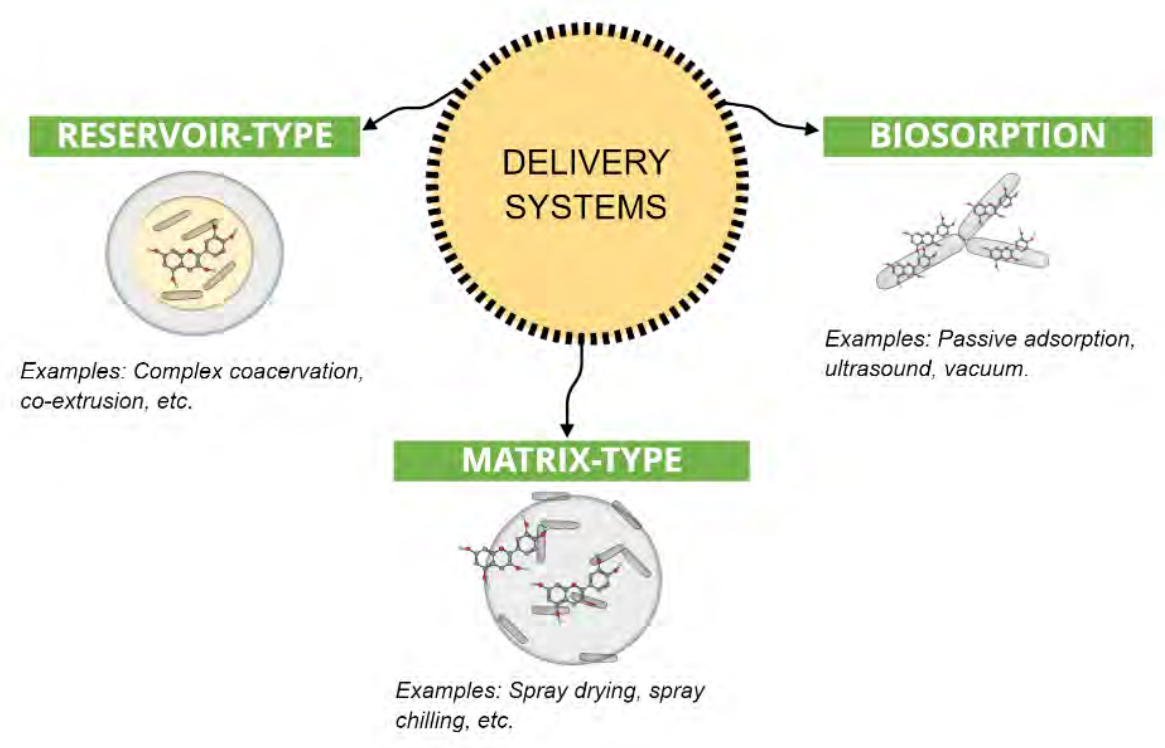

Reference: Own source.

The most common pair of biopolymers for microencapsulation by coacervation complex is gelatin and gum Arabic (ALVIM; GROSSO, 2010). However, the use of gelatin limits the application of these microcapsules in products for the vegetarian audience (KRALOVEC et al., 2012). Several studies investigated different pairs of biopolymers to apply this technique since the selection of biopolymers for encapsulation influences the protection, size and release (SOUZA et al., 2018; COMUNIAN et al., 2016; HOLKEM; FAVARO-TRINDADE, 2020). In addition, microparticles have a low mechanical and thermal resistance due to the interactions of polymers of an ionic nature. In this way, the wall formed by the biopolymers can be strengthened using the crosslinking technique (BURGESS; PONSART, 1998). Among the possible crosslinking agents, transglutaminase is widely used for this purpose (CHAMBI; GROSSO, 2006).

Complex coacervation has shown very promising results in our research group for both hydrophilic and fat-soluble compounds. Some examples of ingredients that have already been microencapsulated by complex coacervation are acid ascorbic (COMUNIAN et al., 2013), xylitol (SANTOS et al., 2015), Echium oil (COMUNIAN et al., 2016), probiotics (OLIVEIRA et al., 2007; SHOJI et al., 2013; SILVA et al., 2018), atomized cinnamon extract (SOUZA et al., 2018). 
In addition, complex coacervation is efficient for stabilizing multiple ingredients, improving the standardization and quality of the final product (ERATTE et al., 2018). In this sense, complex coacervation was suitable for co-encapsulation of tuna oil and probiotics (ERATTE et al., 2015), atomized cinnamon extract and probiotics (HOLKEM; FAVARO-TRINDADE, 2020) and atomized guaraná seed extract and probiotic (SILVA et al., 2022).

\subsubsection{Simultaneous encapsulation of probiotics and plant extracts}

Several studies have already explored the simultaneous encapsulation of probiotics and carbohydrate-based prebiotics, such as inulin, polydextrose, among others (IYER; KAILASAPATHY, 2005; OKURO et al., 2013). Recently, the valorization of food by-products to recover potential carbohydrate-based and phenolic-based prebiotics has been a trend. For instance, apple pomace and cactus peel flour, which are relevant by-products in the Mexican food industry, showed prebiotic potential due to insoluble carbohydrates, improving the viability of coencapsulated probiotics (SERRANO-CASAS et al., 2017).

Some studies that combined plant extracts and probiotics in microparticles are illustrated in Table 2, indicating the protective effect of plant extracts to preserve probiotics in adverse conditions and storage. For instance, green tea extract protected co-encapsulated probiotics by internal emulsification/gelation in simulated gastric conditions (GAUDREAU et al., 2016). Similarly, another study verified that co-extrusion of Lactobacillus acidophilus and apple peel extract protected probiotics and phenolic compounds for 50 days of storage (SHINDE; SUNWATERHOUSE; BROOKS, 2013). Thus, plant extracts contain antioxidant compounds, which enhance the protection of probiotics in stress conditions.

However, despite the promising results, there are still gaps in the action mechanisms of phenolic compounds and probiotics in microparticles. There are some hypotheses: (i) low-water activity microparticles reduce the metabolism of probiotics, indicating that only phenolic compounds may act as an antioxidant during the storage; (ii) probiotics and phenolic compounds loaded in microparticles with high-water activity may establish a synergistic interaction, depending on the storage conditions. 
In addition, co-encapsulation of probiotics and bioactive compounds display as the main challenge the formulation of the delivery system since selection and concentration of bioactive compounds to ensure functionality and encapsulating materials (CHAWDA et al., 2017). In this way, some studies evaluated the different concentrations of plant extracts in microparticles, reporting that high concentrations could be detrimental for probiotics (HOLKEM; FAVAROTRINDADE, 2020; RADDATZ et al., 2022).

In vitro digestion test is widely required to evaluate the efficacy of microparticles loaded with multiple compounds. In this context, applying a standard protocol for in vitro digestion as proposed by Brodkorb et al. (2019) may facilitate the interpretation of data. Unfortunately, most studies used different protocols, which prevents a broader discussion of the results. Additionally, achieving significant results at in vitro digestion assay, in vivo models can be investigated considering the functionality of each bioactive compounds present in the microparticle (CHAWDA et al., 2017). For instance, an 8-week treatment administrating beads loaded with $L$. acidophilus and ginger extract attenuated oxidative stress and restored gut dysbiosis in rats (DEOL et al., 2017). This broad characterization of the microparticle's effectiveness and functionality is relevant for future applications, whether as a supplement or food matrices.

Simultaneous encapsulation of probiotics and plant extracts is advantageous for incorporating food matrices, enhancing the standardization of final products, and masking possible astringency of plant extracts (SILVA et al., 2022). Yogurt was the most used food matrix model for incorporating microparticles in studies displayed in Table 2 (CHAIKHAM, 2015; SHEHATA; ABD-RABOU; EL-SOHAIMY, 2019; SILVA et al., 2022). However, the evaluation of some quality parameters during food storage is required to indicate the influence of microparticles incorporation since bioactive compounds and probiotics can be released in the food matrix, causing some undesirable alterations. Furthermore, the sensory analysis may complement this kind of study, considering launching on the market. 


\subsubsection{Biosorption as a future perspective for simultaneous intake of probiotics and phenolic compounds}

Biosorption can be defined as passive adsorption of some molecules by biological materials. In this sense, probiotics cells are widely used to detoxify food contaminants, such as mycotoxins and heavy metals by biosorption (ŚREDNICKA et al., 2021). In this context, probiotic cells could be used for binding materials of interest for health, such as phenolic compounds, displaying a novel delivery system for simultaneous intake of probiotics and phenolics.

Several studies have been using the biomass of Saccharomyces cerevisiae for biosorption of phenolic compounds from grape pomace (RUBIO et al., 2018), yerba mate (RIBEIRO et al., 2019), açaí pulp and seeds (ROSSETTO et al., 2020), curcumin and fisetin (YOUNG et al., 2017), among others. Some treatments are used to increase the input of bioactive compounds in yeast cells, such as plasmolysis, alkaline solution, ultrasound, heat, etc. Nevertheless, some probiotic strains are susceptible to these treatments, causing their death. In this way, the permeability of probiotic cells can be a challenge for the biosorption of some phenolic compounds from plant extracts due to the high variability of molecules. To solve this problem, vacuum is an excellent approach that temporarily enhances probiotic cells permeability for biosorption of phenolic compounds and maintains their viability (SILVA et al., reviewing). In addition, the vacuum could be used on a large scale in the pharmaceutics and food industries, demonstrating its feasibility. Another advantage of the biosorption of phenolic compounds in probiotic cells is the improvement of probiotic survivability in simulated gastrointestinal conditions without the need to encapsulate (SILVA et al., reviewing). Thus, the biosorption of phenolic compounds in probiotic cells could simultaneously deliver viable probiotic and phenolic compounds in the target. Further studies using in vivo models may indicate the functionality of this approach. 
Table 2 - Co-encapsulation of probiotics and plant extracts, correlating techniques, materials and main outcomes.

\begin{tabular}{|c|c|c|c|}
\hline Materials of interest & Microencapsulation technique & Main outcomes & Reference \\
\hline $\begin{array}{l}\text { Raspberry juice and probiotics } \\
\text { (Lacticaseibacillus rhamnosus } \\
\text { NRRL B-4495 or Lactobacillus } \\
\text { acidophilus NRRL B-442) }\end{array}$ & Spray drying using maltodextrin & $\begin{array}{l}\text { The ratio of maltodextrin affected the } \\
\text { color of raspberry powder, while inlet } \\
\text { temperature influenced the survivability } \\
\text { of probiotics }\end{array}$ & $\begin{array}{l}\text { Anekella and Orsal } \\
\text { (2013) }\end{array}$ \\
\hline $\begin{array}{l}\text { Apple skin extract and } \\
\text { Lactobacillus acidophilus }\end{array}$ & $\begin{array}{l}\text { Co-extrusion using sodium } \\
\text { alginate }\end{array}$ & $\begin{array}{l}\text { Co-extrusion was efficient to protect } \\
\text { probiotics and polyphenols. The presence } \\
\text { of apple skin extract improved the } \\
\text { survivability of encapsulated probiotic in } \\
\text { milk and protected in acidic conditions }\end{array}$ & $\begin{array}{lr}\text { Shinde, } & \text { Sun- } \\
\text { Waterhouse } & \text { and } \\
\text { Brooks (2014) } & \end{array}$ \\
\hline $\begin{array}{l}\text { Probiotics } \text { (Lacticaseibacillus } \\
\text { casei 01, Lactobacillus } \\
\text { acidophilus LA5 and } \\
\text { Bifidobacterium lactis } \text { Bb-12) } \\
\text { and Thai herbal extracts } \\
\text { (cashew flower, pennywort and } \\
\text { yanang) }\end{array}$ & Production of alginate beads & $\begin{array}{l}\text { Cashew flower extract enhanced the } \\
\text { survivability of probiotic in alginate } \\
\text { beads. After application of beads in yogurt } \\
\text { or fruit juices, cashew flower and green } \\
\text { tea extract improved the viability of } \\
\text { products }\end{array}$ & Chaikham (2015) \\
\hline $\begin{array}{l}\text { Lactobacillus helveticus R0052 } \\
\text { and green tea extract }\end{array}$ & Emulsification/internal gelation & $\begin{array}{l}\text { Green tea extract promoted the protection } \\
\text { of probiotics in simulated gastric } \\
\text { condition }\end{array}$ & $\begin{array}{l}\text { Gaudreau et al. } \\
\text { (2016) }\end{array}$ \\
\hline
\end{tabular}




\begin{tabular}{|c|c|c|c|}
\hline $\begin{array}{l}\text { Lactobacillus acidophilus and } \\
\text { ginger extract }\end{array}$ & $\begin{array}{l}\text { Production of alginate beads } \\
\text { containing PEG } 400 \text { and using } \\
\text { eudragit-S100 as coating }\end{array}$ & $\begin{array}{l}\text { The coating improved the release in } \\
\text { colon-target. In-vivo study performed in } \\
\text { mice induced with colitis and } \\
\text { precancerous lesions restored the } \\
\text { oxidative stress, inflammation burden and } \\
\text { dysbiosis }\end{array}$ & Deol et al. (2017) \\
\hline $\begin{array}{l}\text { Blackberry juice and } \\
\text { Lactobacillus acidophillus LA- } \\
5\end{array}$ & $\begin{array}{l}\text { Spray drying using gum Arabic, } \\
\text { maltodextrin and whey protein } \\
\text { concentrate (WPC) }\end{array}$ & $\begin{array}{l}\text { Blend of maltodextrin and gum Arabic } \\
\text { preserved anthocyanins and phenolic } \\
\text { compounds after atomization and during } \\
\text { storage. In contrast, WPC improved the } \\
\text { survivability of probiotic during storage }\end{array}$ & $\begin{array}{l}\text { Colín-Cruz et al. } \\
(2019)\end{array}$ \\
\hline $\begin{array}{l}\text { Probiotics (Lactiplantibacillus } \\
\text { plantarum DSM } 20205 \text { and } \\
\text { Pediococcus acidilactici DSM } \\
\text { 20238) and plant extracts } \\
\text { (moringa, fennel, sage and } \\
\text { green tea) }\end{array}$ & Production of alginate beads & $\begin{array}{l}\text { Moringa extract increased the } \\
\text { survivability of probiotics, even after } \\
\text { incorporation in yogurt and fruit juice }\end{array}$ & $\begin{array}{l}\text { Shehata, Abd-Rabou } \\
\text { and El-Sohaimy } \\
(2019)\end{array}$ \\
\hline $\begin{array}{l}\text { Probiotics (Lacticaseibacillus } \\
\text { paracasei - } \mathrm{BGP1} \text { and } \\
\text { Bifidobacterium animalis } \\
\text { subsp. lactis - BLC1) and } \\
\text { cinnamon extract }\end{array}$ & $\begin{array}{l}\text { Complex coacervation using } \\
\text { vegetable fat, whey protein } \\
\text { concentrate and gum Arabic }\end{array}$ & $\begin{array}{l}\text { Microcapsules containing } 5 \% \text { of } \\
\text { cinnamon extract preserved the viability } \\
\text { of B. animalis subsp. lactis - BLC-1 } \\
\text { during storage of } 120 \text { days at } 7{ }^{\circ} \mathrm{C}\end{array}$ & $\begin{array}{l}\text { Holkem and Favaro- } \\
\text { Trindade (2020) }\end{array}$ \\
\hline
\end{tabular}




\begin{tabular}{|c|c|c|c|}
\hline $\begin{array}{l}\text { Fermented Sohiong fruit with } \\
\text { Lactiplantibacillus plantarum }\end{array}$ & $\begin{array}{l}\text { Spray drying using maltodextrin } \\
\text { and magnesium carbonate }\end{array}$ & $\begin{array}{l}\text { After } 36 \text { days of storage at } 25{ }^{\circ} \mathrm{C} \text {, } \\
\text { probiotic viability was } 6.12 \log \mathrm{CFU} / \mathrm{g}\end{array}$ & Vivek et al. (2020) \\
\hline $\begin{array}{lr}\text { Curcumin } & \text { and } \\
\text { Lacticaseibacillus } & \text { rhamnosus } \\
\text { GG }\end{array}$ & $\begin{array}{l}\text { High-internal phase emulsions } \\
\text { (HIPE's) were prepared using } \\
\text { soybean oil and } \beta \text {-Lactoglobulin- } \\
\text { propylene glycol alginate } \\
\text { composite nanoparticles }\end{array}$ & $\begin{array}{l}\text { Higher concentration of encapsulating } \\
\text { material increased the protection of } \\
\text { curcumin and probiotic in pasteurization. } \\
\text { In addition, HIPE's improved the } \\
\text { survivability of probiotic and the release } \\
\text { of curcumin in simulated gastrointestinal } \\
\text { conditions }\end{array}$ & Su et al. (2020) \\
\hline $\begin{array}{l}\text { Lacticaseibacillus casei } 431 \\
\text { and black rice extracts }\end{array}$ & $\begin{array}{l}\text { Application of whey protein and } \\
\text { inulin followed by freeze-drying }\end{array}$ & $\begin{array}{l}\text { Approximately } 44 \% \text { of anthocyanins from } \\
\text { ethanolic extract decreased in simulated } \\
\text { gastric fluid, whereas aqueous extract } \\
\text { showed a slight reduction. Whey protein } \\
\text { was efficient to protect bioactive } \\
\text { compounds in gastric conditions. During } \\
\text { the storage at } 4{ }^{\circ} \mathrm{C} \text { for } 21 \text { day, the } \\
\text { probiotic count decreased between } 2 \mathrm{log} \\
\text { to } 3.3 \log \mathrm{CFU} / \mathrm{g} \text {. }\end{array}$ & Bolea et al. (2021) \\
\hline $\begin{array}{l}\text { Lacticaseibacillus rhamnosus } \\
\text { GG and black bean extract }\end{array}$ & $\begin{array}{l}\text { Co-extrusion using alginate and } \\
\text { pectin }\end{array}$ & $\begin{array}{l}\text { Application of black bean extract } \\
\text { improved the encapsulation efficiency of } \\
\text { probiotic. Besides that, the survivability } \\
\text { of free probiotic, encapsulated probiotic }\end{array}$ & How et al. (2021) \\
\hline
\end{tabular}




\begin{tabular}{|c|c|c|}
\hline & & $\begin{array}{l}\text { and co-encapsulated probiotic with black } \\
\text { bean extract in simulated gastrointestinal } \\
\text { conditions were approximately } 62.5 \% \text {, } \\
66.8 \% \text { and } 79.9 \% \text {, respectively. }\end{array}$ \\
\hline $\begin{array}{l}\text { Red onion peel extract and } \\
\text { Lacticaseibacillus casei LC03 }\end{array}$ & $\begin{array}{l}\text { External ionic gelation using } \\
\text { sodium alginate }\end{array}$ & $\begin{array}{l}\text { Microcapsules containing } 20 \% \text { of red Raddatz et al. (2022) } \\
\text { onion peel extract improved probiotic } \\
\text { viability in simulated gastrointestinal } \\
\text { conditions. Also, higher concentration of } \\
\text { onion peel extract may be harmful for } \\
\text { encapsulated probiotic due to its } \\
\text { antimicrobial activity }\end{array}$ \\
\hline $\begin{array}{l}\text { Lacticaseibacillus paracasei } \\
\text { BGP-1 and guaraná seed } \\
\text { extract }\end{array}$ & $\begin{array}{l}\text { Complex coacervation using } \\
\text { gelatin and Arabic gum followed } \\
\text { by freeze-drying }\end{array}$ & $\begin{array}{l}\text { Guaraná seed extract improved the Silva et al. (2022) } \\
\text { survivability of probiotic in } \\
\text { microcapsules during storage. Also, } \\
\text { microencapsulation masked the bitter } \\
\text { taste of extract and avoided the post } \\
\text { fermentation of yoghurt }\end{array}$ \\
\hline
\end{tabular}

Reference: Own source. 


\subsection{CHALLENGES}

The overconsumption or misuse of phenolic-rich plant extracts could cause adverse effects on health, which is generally not highlighted in most studies (CORY et al., 2018; GALATI; O'BRIEN, 2004). Galati and O'Brien (2004) discussed about several studies that demonstrated potential toxicities related to phenolic compounds. Also, there is a lack of Dietary Reference Intakes (DRI) for polyphenols and regulations, hindering the estimation of true risks and safety of supplements and fortified foods (WILLIAMSON, HOLST, 2008). In this sense, Cory et al. (2018) reported the importance of whole foods consumption instead of supplements and fortified foods due to the nutritional benefits of fiber and other nutrients, which could positively influence satiety. Although the production of delivery systems containing probiotics and plant extracts is a valuable tool, understanding the toxicological risks for consumers should be addressed in future studies.

\subsection{CONCLUSIONS AND FUTURE REMARKS}

It is undeniable the benefits of probiotics and phytochemicals from plant extracts for gut modulation. Among the phytochemicals, phenolic compounds stand out by their prebiotic potential and assist in the adhesion of probiotics in the intestine, which is another advantage of simultaneous delivery of probiotics and phenolic compounds. In addition, delivery systems containing probiotics and plant extracts enhanced the preservation of bioactive compounds and probiotics during storage and gastrointestinal conditions. However, the evaluation of different concentrations of plant extracts in microparticles may prevent their antimicrobial activity against probiotics, besides toxicological analysis to ensure the safety of consumers. Fortification of food matrices by incorporating microparticles may provide a standard product, maintain the quality parameters, and mask the bitter taste of plant extracts. Until this moment, there is a lack of in vivo studies to extend the understanding of simultaneous intake of probiotics and plant extracts, indicating the urgency of this kind of study. Furthermore, we discussed a novel delivery system using biomass of probiotics for biosorption of phenolics from plant extracts, which could be an alternative to encapsulation techniques. Overall, the development of delivery systems for probiotics and plant extracts is a potential approach for improving probiotic viability, enhancing adhesion in the gut, and increasing phenolics' bioaccessibility. 


\section{REFERENCES}

ALBUQUERQUE, M. A. C. et al. Tropical fruit by-products water extracts as sources of soluble fibres and phenolic compounds with potential antioxidant, anti-inflammatory, and functional properties. Journal of Functional Foods, v. 52, p. 724-733, 2019.

ALVIM, I. D.; GROSSO, C. R. F. Microparticles obtained by complex coacervation: influence of the type of reticulation and the drying process on the release of the core material. Food Science and Technology, Campinas, v. 30, p. 1069-1076, 2010.

ANAND, S.; MANDE, S. S. Diet, Microbiota and Gut-Lung Connection. Frontiers in Microbiology, v. 9, p. 2147, 2018.

ANNUNZIATA, G. et al. Effects of Grape Pomace Polyphenolic Extract (Taurisolo®) in Reducing TMAO Serum Levels in Humans: Preliminary Results from a Randomized, PlaceboControlled, Cross-Over Study. Nutrients, v. 11, p. 139, 2019.

BARBOSA-CÁNOVAS, G. V. et al. Encapsulation processes. IN: BARBOSA-CÁNOVAS, G. V. et al. Food powders: physical properties, processing, and functionality. New York: Kluwer Academic/Plenum Publishers, 2005. cap. 8, p. 199-218.

BERGONZELLI, G. E. et al. GroEL of Lactobacillus johnsonii La1 (NCC 533) Is Cell Surface Associated: Potential Role in Interactions with the Host and the Gastric Pathogen Helicobacter pylor. Infection and Immunity, v. 74, p. 425-434, 2006.

BERMUDEZ-BRITO, M. et al. Probiotic mechanisms of action. Annals of Nutrition and Metabolism, Basel, v. 61, p. 160-174, 2012.

BIANCHI, F. et al. Impact of combining acerola by-product with a probiotic strain on a gut microbiome model. International Journal Of Food Sciences And Nutrition, v. 70, n. 2, p. 182-194, 2018.

BOLEA, C-A et al. Co-Microencapsulated Black Rice Anthocyanins and Lactic Acid Bacteria: evidence on powders profile and in vitro digestion. Molecules, v. 26, n. 9, p. 2579, 2021. 
BROCHOT, A. et al. A Two-Week Treatment with Plant Extracts Changes Gut Microbiota, Caecum Metabolome, and Markers of Lipid Metabolism in ob/ob Mice. Molecular nutrition \& food research, v.63, 2019.

BURGESS, D. J.; PONSART, S. b-glucoronidase activity following complex coacervation and spray drying microencapsulation. Journal of Microencapsulation, v. 15, p. 569-579, 1998.

BUSTOS, I. et al. Effect of Flavan-3-ols on the Adhesion of Potential Probiotic Lactobacilli to Intestinal Cells. Journal of Agricultural and Food Chemistry, v. 60, p. 9082-9088, 2012.

CELEBIOGLU, H. U. et al. Plant Polyphenols Stimulate Adhesion to Intestinal Mucosa and Induce Proteome Changes in the Probiotic Lactobacillus acidophilus NCFM. Molecular Nutrition and Food Research, v. 62, 1700638, 2018.

CHAIKHAM, P. Stability of probiotics encapsulated with Thai herbal extracts in fruit juices and yoghurt during refrigerated storage. Food Bioscience, v. 12, p. 61-66, 2015.

CHAMBI, H.; GROSSO, C. R. F. Edible films produced with gelatin and casein cross-linked with transglutaminase. Food Research International, v. 39, p. 458-466, 2006.

CHAMPAGNE, C. P.; FUSTIER, P. Microencapsulation for the improved delivery of bioactive compounds into foods. Current Opinion in Biotechnology, Oxford, v. 18, p. 184-190, 2007.

CHAVES, F. M. et al. High-intensity-exercise-induced intestinal damage is protected by fermented milk supplemented with whey protein, probiotic and pomegranate (Punica granatum L.). British Journal of Nutrition, v. 119, p. 896-909, 2018.

COLÍN-CRUZ, M. A. et al. Co-encapsulation of bioactive compounds from blackberry juice and probiotic bacteria in biopolymeric matrices. LWT - Food Science and Technology, v. 110, p. 94-101, 2019. 
COMAN, M. M. et al. Polyphenol content and in vitro evaluation of antioxidant, antimicrobial and prebiotic properties of red fruit extracts. European Food Research and Technology, v. 244, p. 735-745, 2018.

COMUNIAN, T. A.; FÁVARO-TRINDADE, C. S. Microencapsulation using biopolymers as an alternative to produce food enhanced with phytosterols and omega-3 fatty acids: A review. Food Hydrocolloids, v. 61, p. 442-457, 2016.

COPPA, G. V. et al. Prebiotics in human milk: a review. Digestive and Liver Disease, v. 38, p. S291-S294, 2006.

CORY, H. et al. The role of polyphenols in human health and food systems: a mini-review. Frontiers in Nutrition, v. 5, article 87, 2018.

CRYAN, J.; DINAN, T. Mind-altering microorganisms: the impact of the gut microbiota on brain and behaviour. Nature Reviews Neuroscience, v. 13, p. 701-712, 2012.

DANG, A. T.; MARSLAND, B. J. Microbes, metabolites, and the gut-lung axis. Mucosal Immunology, v. 12, n. 4, p. 843-850, 2019.

DEOL, P. K. et al. Managing colonic inflammation associated gut derangements by systematically optimised and targeted ginger extract-Lactobacillus acidophilus loaded pharmacobiotic alginate beads. International Journal of Biological Macromolecules, v. 105, p. 81-91, 2017.

DERRIEN, M.; VAN HYLCKAMA VLIEG, J. E. T. Fate, activity, and impact of ingested bacteria within the human gut microbiota. Trends in Microbiology, v. 23, p. 354-366, 2015.

DHAR, D.; MOHANTY, A. Gut microbiota and Covid-19- possible link and implications. Virus Research, v. 285, p. 198018, 2020.

DINAN, T. G.; BORRE, Y. E.; CRYAN, J. F. Genomics of schizophrenia: time to consider the gut microbiome? Molecular Psychiatry, v. 19, p. 1252-1257, 2014. 
DINGEO, G. et al. Phytochemicals as modifiers of gut microbial communities. Food \& function, v. 11, p. 8444-8471, 2020.

ERATTE, D. et al. Co-encapsulation and characterisation of omega-3 fatty acids and probiotic bacteria in whey protein isolate-gum Arabic complex coacervates. Journal of Functional Foods, v. 19, p. 882-892, 2015.

FAO - FOOD AND AGRICULTURE ORGANIZATION OF THE UNITED NATIONS; WHO WORLD HEALTH ORGANIZATION. Evaluation of health and nutritional properties of probiotics in food including powder milk with live lactic acid bacteria. Córdoba, 2001. Disponível em: <ftp://ftp.fao.org/es/esn/food/probioreport_en.pdf〉. Acesso em: 15 maio 2018.

FÁVARO-TRINDADE, C. S.; PINHO, S. C.; ROCHA, G. A. Microencapsulação de ingredients alimentícios. Brazilian Journal of Food Technology, v. 11, p. 103-112, 2008.

GAUDREAU, H. et al. Effect of catechins on the growth of oxygen-sensitive probiotic bacteria. Food Research International, v. 53, p. 751-757, 2013.

GAUDREAU, H. et al. Co-encapsulation of Lactobacillus helveticus cells and green tea extract: Influence on cell survival in simulated gastrointestinal conditions. Journal of Functional Foods, v. 26, p. 451-459, 2016.

GALATI, G.; O'BRIEN, P. J. Potential toxicity of flavonoids and other dietary phenolics: significance for their chemopreventive and anticancer properties. Free Radical Biology and Medicine, v. 37, p. 287-303, 2004.

GARCÍA-HERNÁNDEZ, J. et al. Tomato-antioxidants enhance viability of $L$. reuteri under gastrointestinal conditions while the probiotic negatively affects bioaccessibility of lycopene and phenols. Journal of Functional Foods, v. 43, p. 1-7, 2018.

GENEVOIS, C.; FLORES, S.; ESCALADA, P. M. Byproduct from pumpkin (Cucurbita moschata Duchesne ex poiret) as a substrate and vegetable matrix to contain Lactobacillus case $i$. Journal of Functional Foods, v. 23, p. 210-219, 2016. 
GIBSON, G. R. et al. The International Scientific Association for Probiotics and Prebiotics (ISAPP) consensus statement on the definition and scope of prebiotics. Nature Reviews Gastroenterology \& Hepatology, v. 14, p. 491-502, 2017.

GRZESIK, M. et al. Antioxidant properties of catechins: Comparison with other antioxidants. Food Chemistry, v. 241, p. 480-492, 2018.

HALLORAN, K.; UNDERWOOD, M. A. Probiotic mechanisms of action. Early human development, v. 135, p. 58-65, 2019.

HE, C. et al. Vitamin A inhibits the action of LPS on the intestinal epithelial barrier function and tight junction proteins. Food \& Function, v. 10, p. 1235-1242, 2019.

HO, C. T. Phenolic Compounds in Food and Their Effects on Health. I ACS Symposium Series; American Chemical Society: Washington, DC, 1992.

HOLKEM, A. T.; FAVARO-TRINDADE, C. S. Potential of solid lipid microparticles covered by the protein-polysaccharide complex for protection of probiotics and proanthocyanidin-rich cinnamon extract. Food Research International, v. 136, p. 109520, 2020.

HOW, Y. H. et al. Encapsulation of probiotic strain Lactobacillus rhamnosus GG with black bean extract in alginate-pectin microcapsules. Malaysian Journal of Microbiology, v.17, p.190199, 2021.

HU, K. et al. Phytochemical profiling of the ripening of Chinese mango (Mangifera indica L.) cultivars by real-time monitoring using UPLC-ESI-QTOF-MS and its potential benefits as prebiotic ingredients. Food Chemistry, v. 256, p. 171-180, 2018.

IBRAHIM, F. et al. Probiotic bacteria as potential detoxification tools: assessing their heavy metal binding isotherms. Canadian Journal of Microbiology, v. 52, n. 9, p. 877-885, 2006. 
IYER, C.; KAILASAPATHY, K. Effect of co-encapsulation of probiotics with prebiotics on increasing the viability of encapsulated bacteria under in vitro acidic and bile salt conditions and in yogurt. Journal of Food Science, v. 70, 18-23, 2005.

KING, A.; YOUNG, G. Characteristics and Occurrence of Phenolic Phytochemicals. Journal of the American Dietetic Association, v. 99, p. 213-218, 1999.

KLU, Y. A. K.; CHEN, J. Effect of peanut butter matrices on the fate of probiotics during simulated gastrointestinal passage. LWT - Food Science and Technology, v. 62, p. 983-988, 2015.

KRALOVEC, J. A. et al. A review of the progress in enzymatic concentration and microencapsulation of omega-3 rich oil from fish and microbial sources. Food Chemistry, v. 131, p. 639-644, 2012.

KRASAEKOOPT, W.; WATCHARAPOKA, S. Effect of addition of inulin and galactooligosaccharide on the survival of microencapsulated probiotics in alginate beads coated with chitosan in simulated digestive system, yogurt and fruit juice. LWT - Food Science and Technology, v. 57, p. 761-766, 2014.

KUMAR, M. et al. Human gut microbiota and healthy aging: Recent developments and future prospective. Nutrition and Healthy Aging, v. 4, p. 3-16, 2016

LI, Y. et al. Beneficial effects of a chlorophyll-rich spinach extract supplementation on prevention of obesity and modulation of gut microbiota in high-fat diet-fed mice. Journal of Functional Foods, v. 60, p. 103436, 2019.

LI, Y. et al. Biological transformation of chlorophyll-rich spinach (Spinacia oleracea L.) extracts under in vitro gastrointestinal digestion and colonic fermentation. Food Research International, v. 139, p. 109941, 2021.

LIU, Z. et al. Comparative study of the anti-obesity and gut microbiota modulation effects of green tea phenolics and their oxidation products in high-fat-induced obese mice. Food Chemistry, v. 367, p. 130753, 2022. 
LLANO, D. G. et al. Reciprocal beneficial effects between wine polyphenols and probiotics: an exploratory study. European Food Research and Technology, v. 243, p. 531-538, 2017.

MA, G.; CHEN, Y. Polyphenol supplementation benefits human health via gut microbiota: a systematic review via meta-analysis. Journal of Functional Foods, v. 66, p. 103829, 2020.

MANACH, C. et al. Polyphenols: food sources and bioavailability. The American Journal of Clinical Nutrition, v.79, p.727-747, 2004.

MANGIOLA, F. et al. Gut microbiota in autism and mood disorders. World Journal of Gastroenterology, v. 22, p. 361-368, 2016.

MARINHO, J. F. U. et al. Probiotic and Synbiotic Sorbets Produced with Jussara (Euterpe edulis) Pulp: Evaluation Throughout the Storage Period and Effect of the Matrix on Probiotics Exposed to Simulated Gastrointestinal Fluids. Probiotics and Antimicrobial Proteins, v. 11, p. 264-272, 2019.

MEDEIROS, P. et al. Modulation of Intestinal Immune and Barrier Functions by Vitamin A: implications for current understanding of malnutrition and enteric infections in children. Nutrients, v. 10, n. 9, p. 1128, 2018.

MOLNÁR, P. et al. Biological activity of carotenoids in red paprika, Valencia orange and Golden delicious apple. Phytotherapy Research, v. 19, n. 8, p. 700-707, 2005.

MÖRSCHBÄCHER, A. P. et al. Assessment of selenium bioaccumulation in lactic acid bacteria. Journal of Dairy Science, v. 101, n. 12, p. 10626-10635, 2018.

OKURO, P. K. et al. Co-encapsulation of Lactobacillus acidophilus with inulin or polydextrose in solid lipid microparticles provides protection and improves stability. Food Research International, v.53, p. 96-103, 2013. 
OKURO, P. K.; MATOS JR, F. E.; FÁVARO-TRINDADE, C. S. Technological challenges for spray chilling encapsulation of functional food ingredients. Food Technology and

Biotechnology, Zagreb, v. 51, p. 171-182, 2013.

PÁEZ, R. et al. Study of effects of spray-drying on the functionality of probiotic lactobacilli. International Journal of Dairy Technology, Chichester, v. 66, p. 155-161, 2013.

PELISSARI, J. R. et al. Production of solid lipid microparticles loaded with lycopene by spray chilling: Structural characteristics of particles and lycopene stability. Food and Bioproducts Processing, London, v. 98, p. 86-94, 2016.

PEREIRA, A. L. F.; MACIEL, T. C.; RODRIGUES, S. Probiotic beverage from cashew apple juice fermented with Lactobacillus casei. Food Research International, v. 44, n. 5, p. 12761283, 2011.

PERES, C. M. et al. Synergy of olive bioactive phytochemicals and probiotic strain in control of Escherichia coli. LWT - Food Science and Technology, v. 64, p. 938-945, 2015.

PÉREZ, P. F. et al. Surface properties of bifidobacterial strains of human origin. Applied and environmental microbiology, v. 64, p. 21-26, 1998.

RADDATZ, G. C. et al. Viability and stability evaluation of Lactobacillus casei LC03 coencapsulated with red onion (Allium cepa L.) peel extract. LWT - Food Science and Technology, v. 153, 112434, 2022.

ROCA, M.; CHEN, K.; PÉREZ-GÁLVEZ, A. Chlorophylls. Handbook On Natural Pigments In Food And Beverages, p. 125-158, 2016.

RODRIGUEZ-AMAYA, D. B. Update on natural food pigments - A mini-review on carotenoids, anthocyanins, and betalains. Food Research International, v. 124, p. 200-205, 2019.

ROMAN, P. et al. A Pilot Randomized Controlled Trial to Explore Cognitive and Emotional Effects of Probiotics in Fibromyalgia. Scientific Reports, v. 8, 2018. 
SANTOS, A. S. et al. Effects of Quercetin and Resveratrol on in vitro Properties Related to the Functionality of Potentially Probiotic Lactobacillus Strains. Frontiers in Microbiology, v. 10, 2229, 2019.

SANTOS, C. S. et al. Effect of enzymatic interesterification on the textural and nutritional properties of a probiotic table spread containing milk fat. LWT - Food Science and Technology, v. 124, 109129, 2020.

SANTOS, M. G. et al. Microencapsulation of xylitol by double emulsion followed by complex coacervation. Food Chemistry, v. 171, p. 32-39, 2015.

SERRA, D.; ALMEIDA, L. M.; DINIS, T. C. P. Dietary polyphenols: A novel strategy to modulate microbiota-gut-brain axis. Trends in Food Science \& Technology, v. 78, p. 224-233, 2018.

SERRANO-CASAS, V. et al. Improvement of lactic acid bacteria viability in acid conditions employing agroindustrial co-products as prebiotic on alginate ionotropic gel matrix coencapsulation. Journal of Functional Foods, v. 38, p. 293-297, 2017.

SHEHATA, M. G. et al. Plant Extracts in Probiotic Encapsulation: Evaluation of their Effects on Strains Survivability in Juice and Drinkable Yogurt During Storage and an in-vitro Gastrointestinal Model. Journal of Pure and Applied Microbiology, v. 13, p. 609-617, 2019.

SHINDE, T. S.; BROOKS, J. D.; SUN-WATERHOUSE, D. Preparation and use of apple skin polyphenol extracts in milk: enhancement of the viability and adhesion of probiotic Lactobacillus acidophilus (ATCC 1643) bacteria. International Journal of Food Science, v. 50, p. 1303-1310, 2015.

SHINDE, T.; SUN-WATERHOUSE, D.; BROOKS, J. Co-extrusion encapsulation of probiotic Lactobacillus acidophilus alone or together with apple skin polyphenols: an aqueous and valueadded delivery system using alginate. Food and Bioprocess Technology, v. 7, p. 1581-1596, 2014. 
SILVA, C. P. et al. Polyphenols from guaraná after in vitro digestion: Evaluation of bioacessibility and inhibition of activity of carbohydrate-hydrolyzing enzymes. Food Chemistry, 2017.

SILVA, M. P. et al. Fortification of yoghurt drink with microcapsules loaded with Lacticaseibacillus paracasei BGP-1 and guarana seed extract. International Dairy Journal, v. 125, 105230, 2022.

SILVA, M. P. et al. Semisweet chocolate as a vehicle for the probiotics Lactobacillus acidophilus LA3 and Bifidobacterium animalis subsp lactis BLC1: Evaluation of chocolate stability and probiotic survival under in vitro simulated gastrointestinal conditions. LWT - Food Science and Technology, v. 75, p. 640-647, 2017.

SILVA, M. P. et al. Microcapsules loaded with the probiotic Lactobacillus paracasei BGP-1 produced by co-extrusion technology using alginate/shellac as wall material: Characterization and evaluation of drying processes. Food Research International, Kidlington, v. 89, p. 582590, 2016.

SILVEIRA, A. K. et al. Guarana (Paullinia cupana Mart.) alters gut microbiota and modulates redox status, partially via caffeine in Wistar rats. Phytotherapy Research, v. 32, n. 12, p. 24662474, 2018.

SINISGALLI, C. et al. The Beneficial Effects of Red Sun-Dried Capsicum annuиm L. Cv Senise Extract with Antioxidant Properties in Experimental Obesity are Associated with Modulation of the Intestinal Microbiota. Molecular Nutrition \& Food Research, v. 65, n. 3, p. 2000812, 2020.

SONG, H. et al. Dietary anthocyanin-rich extract of açai protects from diet-induced obesity, liver steatosis, and insulin resistance with modulation of gut microbiota in mice. Nutrition, v. 86, p. 111176, 2021.

SU, J. et al. High-internal-phase emulsions (HIPEs) for co-encapsulation of probiotics and curcumin: enhanced survivability and controlled release. Food \& Function, v. 12, n. 1, p. 70-82, 2021. 
SUN, X. et al. Modulation of Gut Microbiota by Fucoxanthin During Alleviation of Obesity in High-Fat Diet-Fed Mice. Journal of Agricultural and Food Chemistry, v. 68, n. 18, p. 51185128, 2020.

TREML, J.; SMEJKAL, K. Flavonoids as Potent Scavengers of Hydroxyl Radicals. Comprehensive Reviews in Food Science and Food Safety, v. 15, p. 720-738, 2016.

VALDÉS, L. et al. The relationship between phenolic compounds from diet and microbiota: impact on human health. Food \& Function, v. 6, p.2424-2439, 2015.

VENDRAME, S. et al. Six-Week Consumption of a Wild Blueberry Powder Drink Increases Bifidobacteria in the Human Gut. Journal of Agricultural and Food Chemistry, v. 59, p. 12815-12820, 2011.

VIVEK, K. et al. Characterization of spray dried probiotic Sohiong fruit powder with Lactobacillus plantarum. LWT - Food Science and Technology, v. 117, p. 108699, 2020.

VOLSTATOVA, T. et al. Effect of apple extracts and selective polyphenols on the adhesion of potential probiotic strains of Lactobacillus gasseri R and Lactobacillus casei FMP. Journal of Functional Foods, v. 35, p. 391-397, 2017.

WIESE, M. et al. Prebiotic Effect of Lycopene and Dark Chocolate on Gut Microbiome with Systemic Changes in Liver Metabolism, Skeletal Muscles and Skin in Moderately Obese Persons. BioMed research international, 4625279, 2019.

WILLIAMSON, G.; HOLST, B. Dietary reference intake (DRI) value for dietary polyphenols: are we heading in the right direction? British Journal of Nutrition, v. 99, S55-S58, 2008.

WU, Y. et al. In vitro gastrointestinal digestion and fecal fermentation reveal the effect of different encapsulation materials on the release, degradation and modulation of gut microbiota of blueberry anthocyanin extract. Food Research International, v. 132, p. 109098, 2020. 
YONEKURA, L. et al. Bioavailability of catechins from guaraná (Paullinia cupana) and its effect on antioxidant enzymes and other oxidative stress markers in healthy human subjects.

Food \& Function, v. 7, p. 2970-2978.

YOUNG, S.; DEA, S.; NITIN, N. Vacuum facilitated infusion of bioactives into yeast microcarriers: Evaluation of a novel encapsulation approach. Food Research International, v. 100, p. 100-112, 2017.

ZHAO, D.; SHAH, N. P. Tea and soybean extracts in combination with milk fermentation inhibit growth and enterocyte adherence of selected foodborne pathogens. Food Chemistry, v. 180, p. 306-316, 2015.

ZHU, M-Z. et al. Combined use of epigallocatechin-3-gallate (EGCG) and caffeine in low doses exhibits marked anti-obesity synergy through regulation of gut microbiota and bile acid metabolism. Food \& Function, 12, 4105, 2021. 
3 CHAPTER 2 - CO-ENCAPSULATION OF GUARANÁ EXTRACTS AND PROBIOTICS INCREASES PROBIOTIC SURVIVABILITY AND SIMULTANEOUSLY DELIVERS BIOACTIVE COMPOUNDS IN SIMULATED GASTROINTESTINAL FLUIDS

Manuscript submitted to the Journal "LWT-Food Science and Technology" 


\title{
3 CHAPTER 2 - CO-ENCAPSULATION OF GUARANÁ EXTRACTS AND PROBIOTICS INCREASES PROBIOTIC SURVIVABILITY AND SIMULTANEOUSLY DELIVERS BIOACTIVE COMPOUNDS IN SIMULATED GASTROINTESTINAL FLUIDS
}

\begin{abstract}
Co-encapsulation addresses the protection of multiple compounds from harmful conditions. However, the release of entrapped bioactive compounds and probiotics in the gut is required to achieve their health benefits. This study focused on the co-encapsulation of probiotics and guaraná extracts by complex coacervation using gelatin and gum Arabic, evaluating the release of encapsulated probiotics and bioactive compounds during in vitro digestion. The antioxidant activity of guaraná extracts and their stimulatory effect on probiotic populations were also investigated. Guaraná seed extract (GSE) showed more significant antioxidant activity. Concerning the influence of guaraná extracts on the growth of probiotics, guaraná peel extract (GPE) prolonged their growth. The release of encapsulated phenolic compounds from GSE was higher in simulated gastric fluid (SGF), reaching at least $80 \%$ of accumulative release after $2 \mathrm{~h}$. In contrast, the maximum release of encapsulated carotenoids from GPE was around 90\% in simulated intestinal fluid (SIF). Furthermore, the co-encapsulation of probiotics and guaraná extracts improved the final number of cells found in SIF, which was around $7 \log \mathrm{CFU} / \mathrm{mL}$. Therefore, co-encapsulation by complex coacervation is efficient for simultaneous delivery of bioactive compounds and probiotics to the gut, extending their benefits by this combination.
\end{abstract}

Keywords: complex coacervation, polyphenols, carotenoids, antioxidant capacity, L. paracasei, $B$. animalis subsp. lactis 


\subsection{INTRODUCTION}

The current concern about health has increased consumers' interest in the supplementation of bioactive compounds and probiotics due to their beneficial effects. For instance, the consumption of phenolic compounds and carotenoids may reduce degenerative and cardiovascular diseases, respectively (MANACH et al., 2004; RODRIGUEZ-AMAYA, 2019), while probiotic supplementation aids gastrointestinal and immune health (HILL et al., 2014). In this way, the combination of bioactive compounds and probiotics, whether through food or supplements, could be a valuable strategy to extend their health benefits. In addition, there is some evidence that probiotics and polyphenols may interact positively in gut health (VALDÉS et al., 2015). For instance, polyphenols present antimicrobial activity, reducing the proliferation of pathogenic microorganisms in the gut (ZHAO; SHAH, 2015). Also, plant polyphenols are emerging prebiotics due to their stimulatory effect on the growth of beneficial gut microbiota, which consequently enhances the bioavailability of polyphenols (GIBSON et al., 2017; KAWABATA et al., 2019). Thus, plant phenolic compounds stand out from carbohydrate-based prebiotics for their antioxidant activity and synergistic effect with probiotics.

The incorporation of probiotics in plant food matrices, such as passion fruit juice (DIAS et al., 2018) and jussara sorbet (MARINHO et al., 2019), has been explored to develop healthier products. However, it can be a challenge to maintain the viability of some probiotic strains when they are applied in food matrices, considering the physical-chemical characteristics of the food matrix, such as low $\mathrm{pH}$, the presence of oxygen, and storage temperature. Thus, a potential technology for combining these bioactive compounds and probiotics is co-encapsulation, which is based on packaging the materials of interest to protect them from environmental conditions (COMUNIAN; FAVARO-TRINDADE, 2016). Furthermore, the microcapsules can be used as a supplement or added to the food matrix. However, the choice of microencapsulation technique and polymers for packaging the bioactive compounds and probiotics drives their release during digestion.

Among the encapsulation techniques that have been used to investigate the simultaneous protection of probiotics and bioactive compounds are emulsification/internal gelation (GAUDREAU et al., 2016), spray drying (VÁSQUEZ-MALDONADO et al., 2020), and complex coacervation (ERATTE et al., 2015). Coacervates are produced after the phase separation of charged polymers, mainly with the adjustment of $\mathrm{pH}$, providing electrostatic interaction between 
the opposing charges of polymers surrounding the core material (GOUIN, 2004; TIMILSENA et al., 2019). Several proteins and polysaccharides are explored for encapsulation by complex coacervation, but the classical pair of polymers is gelatin/gum Arabic generally used in studies. Furthermore, comprehension of biopolymers' properties is relevant for encapsulation, such as molecular weights, concentrations, and ionic charges, which significantly affect coacervates' production (EGHBAL; CHOUDHARY, 2018; TIMILSENA et al., 2019). Although complex coacervation has been widely explored for the protection of hydrophobic materials, some recent studies have demonstrated its potential to preserve phenolic compounds and probiotics (HOLKEM; FAVARO-TRINDADE, 2020; SILVA et al., 2022). This method can protect food and cosmetic ingredients, natural repellents, and others (TIMILSENA et al., 2019). Release studies of coacervates loaded simultaneously with bioactive compounds and probiotics in simulated gastrointestinal fluids are relevant for understanding the influence of antioxidant compounds in increasing the number of viable cells that reaches the gut.

Guaraná is an Amazonian fruit which has been investigated due to the caffeine and phenolic compounds in its seeds (SANTANA; MACEDO, 2018), which are used as a supplement and to produce energy beverages. Guaraná peel is discarded during processing and used as a fertilizer with no aggregate value. However, guaraná peel is a source of bioactive compounds, such as $\beta$ carotene and lutein (PINHO et al., 2021). The full use of guaraná would add value to the fruit since carotenoids and phenolic compounds have antioxidant properties. For this reason, the combination of guaraná extracts with probiotics is promising for reducing the oxidative stress of cells and extending their viability during stress conditions, such as the digestion process.

Therefore, the overall aims of this study were (i) to evaluate the antioxidant activity of guaraná seed extract (GSE) and guaraná peel extract (GPE); (ii) to verify the prebiotic potential of GSE and GPE during in vitro incubation with probiotics, and the hydrophobicity of probiotic cells; (iii) to co-encapsulate guaraná extracts and probiotics by complex coacervation; (iv) to assess the release of phenolic compounds, carotenoids, and probiotics during an in vitro digestion assay. Graphical abstract of this study is illustrated in Figure 5. 
Figure 5 - Graphical abstract of the present study.

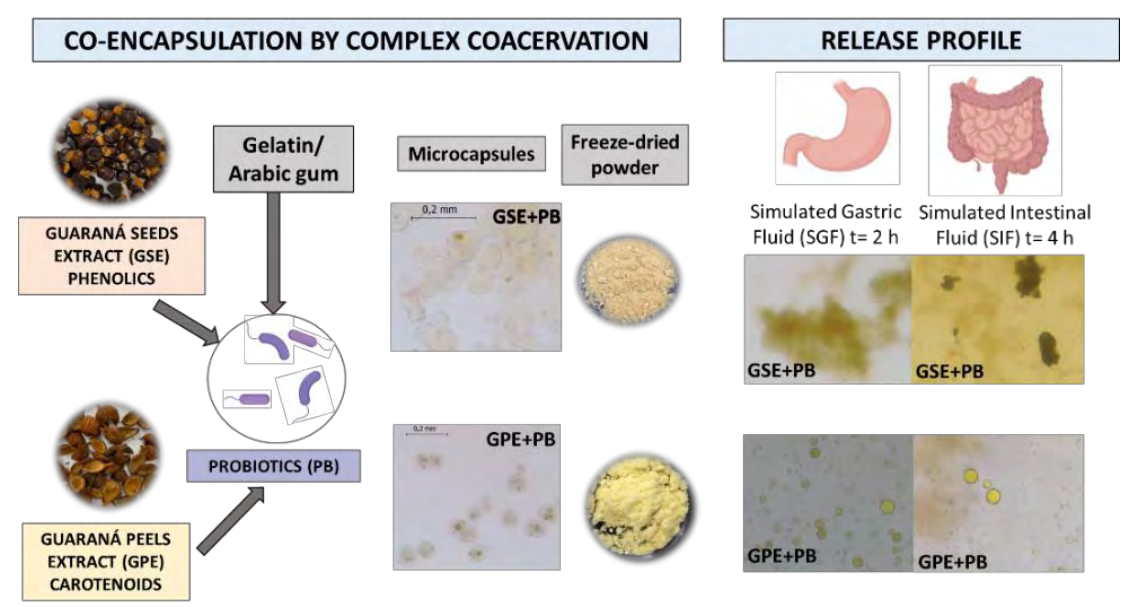

Reference: Own source.

\subsection{MATERIAL AND METHODS}

\subsubsection{Materials}

Lacticaseibacillus paracasei BGP-1 and Bifidobacterium animalis subsp. lactis BLC-1 were donated by Sacco (Campinas, Brazil). Guaraná fruits were provided by the Executive Commission of the Rural Economic Recuperation Plan in Cacao (Taperoá, Brazil). As encapsulating materials, type A swine gelatin (Gelnex, Itá, Brazil) and Arabic gum (Nexira, São Paulo, Brazil) were used. ABTS, DPPH, and Trolox reagents were purchased from Sigma-Aldrich (St. Louis, USA).

\subsubsection{Analytical methods}

\subsubsection{Total phenolic content (TPC)}

TPC was evaluated according to Singleton et al. (1999) with modification. Thus, $0.25 \mathrm{~mL}$ of extract was added in $2 \mathrm{~mL}$ of distilled water and $0.25 \mathrm{~mL}$ of the Folin-Ciocalteu reagent. After, $0.25 \mathrm{ml}$ of saturated sodium carbonate was added to the mixture, vortexed, and incubated in a water bath at $37{ }^{\circ} \mathrm{C}$ for $30 \mathrm{~min}$ to complete the reaction. Measurement of the absorbance was carried out using a spectrophotometer at $750 \mathrm{~nm}$, and gallic acid was applied as a reference for the calculation of TPC. 


\subsubsection{Total carotenoids (TC)}

The organic phase was read using a spectrophotometer at $450 \mathrm{~nm}$, and TC was calculated using Equation 1.

$$
T C(\mu g / m l)=\frac{\text { Absorbance } \times \operatorname{Volume}(m L) \times 10^{4}}{\text { Absorption coef } \times \operatorname{Sample} \text { weight }(g)} \quad \text { Eq. (1) }
$$

Where: absorption coefficient of 2500, which is recommended for mixtures (RodriguezAmaya, 1999).

\subsubsection{Antioxidant activities by ABTS, DPPH, ORAC}

Antioxidant activities of spray-dried GSE (without carrier) and concentrated GPE were evaluated for free radical scavenging activity DPPH and ABTS, as well as peroxyl radical scavenging capacity (ORAC).

The free radical scavenging activity of DPPH (2,2-diphenyl-1-picrylidyl radical, SigmaAldrich) was evaluated according to Melo et al. (2015). For this, $66 \mu \mathrm{L}$ of sample and $134 \mu \mathrm{L}$ of DPPH solution $(150 \mu \mathrm{M})$ were added in a 96-well microplate, following by homogenization. Then, the microplate was protected from light for a reaction for $45 \mathrm{~min}$, reading the absorbance at 517 nm.

ABTS free radical scavenging activity was performed as described by Al-Duais et al. (2009) and Melo et al. (2015). First, the ABTS radical was diluted with potassium phosphate buffer to obtain an approximate absorbance of 0.7 in wavelength at $734 \mathrm{~nm}$. About $20 \mu \mathrm{L}$ of the extracts and $220 \mu \mathrm{L}$ of the ABTS radical solution were added to the 96-well microplate and maintained protected from the light. After the addition of ABTS radical solution, samples were kept for 6 minutes to finalize the reaction before the absorbance readings at $734 \mathrm{~nm}$.

ORAC was conducted using the methodology suggested by Melo et al. (2015). Microplate reader (Molecular Devices, LLC, Sunnyvale, CA, USA) was set up for kinetic reading each minute during $2 \mathrm{~h}\left(\kappa_{\text {emission }}=582 \mathrm{~nm}\right.$ and $\left.\kappa_{\text {excitation }}=485 \mathrm{~nm}\right)$. Approximately $30 \mu \mathrm{L}$ of the sample, $60 \mu \mathrm{L}$ of fluorescein solution $(508.25 \mathrm{nM})$, and $110 \mu \mathrm{L}$ dihydrochloride (AAPH) were added to a 96-well plate.

All antioxidant activities of GSE and GPE were expressed as $\mu$ mol Trolox equivalents/g sample since Trolox was used as a standard for these methods. 


\subsubsection{Probiotic inoculum}

Preparation of probiotic suspension was performed by adding $50 \mathrm{mg}$ of freeze-dried probiotic cells in $10 \mathrm{~mL}$ of MRS broth for incubation at $37^{\circ} \mathrm{C}$ for $18 \mathrm{~h}$. Then, the probiotic suspension was added in $100 \mathrm{~mL}$ of MRS broth, followed by incubation. Cells were collected by centrifugation and resuspended in $2 \%$ sodium citrate for further analysis.

\subsubsection{Enumeration of probiotic}

Aliquots of $100 \mu \mathrm{L}$ were withdrawn, serially diluted, followed by the inoculation of bacterial suspension into MRS agar. Plates were incubated in an anaerobic jar at $37{ }^{\circ} \mathrm{C}$ for $48 \mathrm{~h}$. Enumeration of viable probiotics was performed after the incubation of plates at $37^{\circ} \mathrm{C}$ in anaerobic jar for $48 \mathrm{~h}$.

\subsubsection{Procedures}

\subsubsection{Production of guaraná extracts}

First, guaraná fruit was washed, separating the seeds and peels followed by drying at $40{ }^{\circ} \mathrm{C}$ for $24 \mathrm{~h}$ to avoid contamination during storage. Guaraná seed extract (GSE) was produced as proposed by Silva et al. (2021) using ethanol $30 \%(\mathrm{v} / \mathrm{v})$ at $60^{\circ} \mathrm{C}$ and mechanical agitation for recovery of phenolic compounds. Ethanol was removed by atomization using a spray-dryer MSD 1 (LabMaq, Brazil) containing a 1.2 nozzle at $150^{\circ} \mathrm{C}$ and $10 \mathrm{~mL} / \mathrm{min}$ of feed flow.

Concerning the preparation of rich-carotenoid extract from guaraná, peels were crushed using a blender. Crushed peel was put in contact with absolute ethanol to extract carotenoids in the proportion 1 to 10 . The guaraná peel extract (GPE) production was performed using a water bath at $50{ }^{\circ} \mathrm{C}$ for $2 \mathrm{~h}$ and mechanical stirring. Then, GPE was evaporated using a rotaevaporator. For this, 3\% (w/w) of sunflower oil was added into guaraná peel extract to preserve carotenoids during evaporation, obtaining an oil with carotenoids.

\subsubsection{In vitro antimicrobial activity of guaraná extracts}

The in vitro antimicrobial activity of guaraná extracts against probiotic cells was determined by inoculation of guaraná extracts onto MRS agar according to Martin et al. (2012) with modification. The probiotic inoculum was prepared as described in section 2.3.3, diluting the 
bacterial pellet in $2 \%$ sodium citrate for a final population of $8 \log$ CFU/mL. Approximately $1 \mathrm{~mL}$ of probiotic inoculum was added to $100 \mathrm{~mL}$ of the previously cooled semi-solid MRS agar composed of $3.7 \%(w / v)$ MRS agar and 1.8\% (w/v) MRS broth. The semi-solid MRS agar was placed in Petri dishes and $5 \mathrm{~mm}$ wells were made after $60 \mathrm{~min}$. Then, $40 \mu \mathrm{L}$ of pure guaraná extracts was pipetted onto MRS agar and incubated at $37{ }^{\circ} \mathrm{C}$ for $48 \mathrm{~h}$. Also, $40 \mu \mathrm{L}$ of diluted guaraná extracts $(1: 1,1: 2,1: 3)$ was assessed. In addition, distilled water and tetracycline solution $(50 \mathrm{mg} / \mathrm{mL})$ (Sigma-Aldrich, St. Louis, MO, USA) were used as negative and positive controls, respectively.

\subsubsection{Influence of guaraná extracts on the growth of probiotics}

Interaction between probiotics and guaraná extracts was evaluated following the methodology proposed by China et al. (2012) with modification. Approximately $0.5 \mathrm{~g}$ of spraydried GSE was rehydrated in $20 \mathrm{~mL}$ of distilled water and filter-sterilized $(0.22 \mu \mathrm{m})$, whereas concentrated GPE, previously filter-sterilized $(0.22 \mu \mathrm{m})$, was evaluated. Then, supplemented MRS broth was prepared using $4 \mathrm{~mL}$ of MRS broth and $1 \mathrm{~mL}$ of GSE or GPE, referred to as MRS broth supplemented with $20 \%$ (v/v) of guaraná extracts. In addition, $10 \%$ (v/v) and 5\% (v/v) guaraná extract supplementation in MRS broth was evaluated using 0.5 or $0.25 \mathrm{~mL}$ of guaraná extract, respectively. The final volume was maintained at $5 \mathrm{~mL}$ using sterilized water. Finally, $10 \mu \mathrm{L}$ of probiotic inoculum (8 $\log \mathrm{CFU} / \mathrm{mL}$ ), previously prepared as described in section 3.2.2.4, was inoculated in MRS broth. As a control, probiotic was added to MRS broth without guaraná extracts. The probiotic suspension was incubated at $37{ }^{\circ} \mathrm{C}$ for $96 \mathrm{~h}$. Then, an aliquot of $100 \mu \mathrm{L}$ of each sample was withdrawn at the initial time and after 24, 48, 72, and $96 \mathrm{~h}$ of incubation, diluted in $2 \%$ sodium citrate solution, and enumerated onto MRS agar, as described in section 3.2.2.5.

\subsubsection{Hydrophobicity of probiotics}

Cell surface hydrophobicity was carried out following the methodology proposed by Vinderola, Medici and Perdigón (2004). Probiotics inoculum was produced as described previously in section 3.2.2.4. In addition, the supplementation of MRS broth with $10 \%$ of guaraná extracts was evaluated to check if the cell hydrophobicity may change during incubation. After incubation, probiotic cells were washed three times with phosphate-buffered saline (PBS) solution. Initially, the optical density (OD) of probiotic cells was adjusted to 0.8 at $560 \mathrm{~nm}$. After, $0.6 \mathrm{~mL}$ 
of $\mathrm{n}$-hexadecane was added in $3 \mathrm{~mL}$ of cell suspension. Tubes were vortexed for $2 \mathrm{~min}$; after $1 \mathrm{~h}$ with the complete phase separation, the aqueous phase was removed for reading in a spectrophotometer at $560 \mathrm{~nm}$. The percentage of hydrophobicity was calculated as equation below:

$$
H(\%)=\left[\left(A_{0}-A\right) / A_{0}\right] \times 100 \quad \text { Eq. (2) }
$$

$\mathrm{A}_{0}$ and $\mathrm{A}$ were the OD of the aqueous phase before and after the contact with $\mathrm{n}$-hexadecane.

\subsubsection{Simultaneous encapsulation of probiotic and guaraná extracts}

Control microcapsules were produced without the addition of guaraná extracts according to Silva et al. (2018) with modifications. First, $1 \mathrm{~g}$ of probiotic pellet was dispersed in $2.5 \%$ (w/w) gelatin solution at $6000 \mathrm{rpm}$ for $1 \mathrm{~min}$, followed by adding $2.5 \%$ (w/w) Arabic gum solution and adjusting $\mathrm{pH}$ to 4 using citric acid (5 M). The mixture was maintained under magnetic stirring until temperature reached $10{ }^{\circ} \mathrm{C}$.

Concerning the microcapsules loaded with probiotics and GPE, approximately $1 \mathrm{~g}$ of probiotics pellet was dispersed in $1.5 \mathrm{~g}$ of GPE at $3600 \mathrm{rpm}$ for $1 \mathrm{~min}$. Then, a $2.5 \%$ (w/w) gelatin solution was added to the mixture at $6000 \mathrm{rpm}$ for $60 \mathrm{~s}$. Arabic gum solution was added in the mixture and kept by magnetic stirring, and the $\mathrm{pH}$ was adjusted to 4.2 using citric acid (5 M). Magnetic stirring was stopped after the reduction of temperature to $10^{\circ} \mathrm{C}$.

Probiotic and GSE were encapsulated as described by Souza et al. (2018) and Silva et al. (2021) with modification. First, about $1.25 \mathrm{~g}$ of spray-dried GSE was rehydrated in $200 \mathrm{~mL}$ of deionized water by Ultra Turrax (IKA, Staufen, Germany) at $6000 \mathrm{rpm}$ for $2 \mathrm{~min}$. Next, aqueous GSE was added in 5\% (w/w) gelatin solution and homogenized at $12000 \mathrm{rpm}$ for 2 min using an Ultra Turrax (Ika, Staufen, Germany). In the last minute of homogenization, a probiotic pellet was put in the mixture. Then, 5\% (w/w) Arabic gum solution was added to the mixture and kept by magnetic stirring, adjusting the $\mathrm{pH}$ to 3.8 using citric acid (5 M). After temperature decrease to 10 ${ }^{\circ} \mathrm{C}$, the mixture was kept in the refrigerator at $7{ }^{\circ} \mathrm{C}$ overnight for decantation. Then, all coacervates were freeze-dried in a lyophilizer (LC 1500, Terroni, Brazil) for $48 \mathrm{~h}$. 


\subsubsection{Characterization of microcapsules}

\subsubsection{Particle size and morphology}

Particle size of wet microcapsules was evaluated by laser diffraction (Shimadzu Sald-201V particle size analyzer, Kyoto, Japan). Thus, microparticles were dispersed in distilled water.

The morphology of wet microcapsules was qualitatively analyzed using a confocal laser scanning microscope (Leica Microsystems GmbH, SP5, Germany), with an objective of 63x (1.4 aperture and oil immersion). The microcapsules were dyed with live/dead kit to evaluate the resistance of probiotic cells after encapsulation. Live was excited with Argon laser at $488 \mathrm{~nm}$, and the emitted light was recorded between 500 to $550 \mathrm{~nm}$. Live was excited with HeNe laser at 543 $\mathrm{nm}$, and the emitted light was recorded between 588 to $682 \mathrm{~nm}$. Besides that, Nile red dye (excitation: $488 \mathrm{~nm}$, emission: 515-645 $\mathrm{nm}$ ) was used to verify the encapsulation of GPE. These analyses were made in the Multi-User Laboratory for Confocal Microscopy - LMMC at Faculdade de Medicina de Ribeirao Preto (FMRP-USP).

After freeze-drying of microcapsules, the morphology of formulations was evaluated using a scanning electron microscope (TM3000 Tabletop Microscope, Japan). First, freeze-dried powders were accommodated on double-faced carbon tapes (Ted Pella, Inc., Redding, USA), attaching on aluminum stubs. Images were captured at a voltage of $5 \mathrm{kV}$ and magnification of $\times 500$.

3.2.4.2 Quantification of total phenolic content (TPC), total carotenoids (TC) and enumeration of probiotics loaded in microcapsules

TPC in microcapsules was evaluated as described by Souza et al. (2020). First, $0.1 \mathrm{~g}$ of freeze-dried microcapsules were added in $2.5 \mathrm{~mL}$ of $\mathrm{NaOH}$ solution $(0.1 \mathrm{M})$ and $5 \mathrm{~mL}$ of $0.5 \%$ (v/v) acetic acid in acetone solution. The release was performed in Multi Reax Vortex (Heidolph, Schwabach, Germany) for $30 \mathrm{~min}$, following by centrifugation at $7500 \mathrm{rpm}$ for $5 \mathrm{~min}$. The aqueous phase was collected to quantify the TPC as described in section 3.2.2.1.

Total carotenoids content (TC) of microcapsules was determined by adding $0.1 \mathrm{~g}$ of microcapsules in $2.5 \mathrm{~mL}$ of $2 \%$ sodium citrate solution and incubation at $40{ }^{\circ} \mathrm{C}$ for $5 \mathrm{~min}$. Then, 5 $\mathrm{mL}$ of hexane was added to this mixture, and samples were sonicated for $5 \mathrm{~min}$. The organic phase was separated by centrifugation at $5000 \mathrm{rpm}$ for $5 \mathrm{~min}$. An exhaustion extraction procedure was performed three times to complete the removal of the yellow color of microcapsules. The 
absorbance of the organic phase was measured in a spectrophotometer at $450 \mathrm{~nm}$ and quantified as described in section 3.2.2.2

Encapsulated probiotic was released by adding $2 \%$ sodium citrate solution and agitation in the vortex for $10 \mathrm{~min}$. Enumeration of released probiotics was performed as described in section 3.2.2.5.

3.2.4.3 Release of encapsulated probiotic and bioactive compounds in simulated gastrointestinal conditions

Release of encapsulated probiotics, phenolics and total carotenoids in simulated gastrointestinal fluids was performed according to Minekus et al. (2014) with modification. In this way, the composition of simulated salivary fluid (SSF), simulated gastric fluid (SGF), and simulated intestinal fluid (SIF), followed the concentrations of electrolytes recommended by Minekus et al. (2014). Then, approximately $0.5 \mathrm{~g}$ of freeze-dried microcapsules were added in 1.5 $\mathrm{mL}$ of distilled water and $2 \mathrm{~mL} \mathrm{SSF}$ for $2 \mathrm{~min}$. Sequentially, $4 \mathrm{~mL}$ of SGF was added to the tubes followed by adjusting $\mathrm{pH}$ to $3 \mathrm{using} \mathrm{HCl}(6 \mathrm{M})$ and the addition of $0.2 \mathrm{~mL}$ of pepsin solution (2000 $\mathrm{U} / \mathrm{mL}$ ). Tubes were incubated at $37{ }^{\circ} \mathrm{C}, 200 \mathrm{rpm}$ for $120 \mathrm{~min}$. After, SIF (50:50 v/v) was applied in the preceding mixture, and $\mathrm{pH}$ was changed to 7 using $\mathrm{NaOH}(1 \mathrm{M})$. Also, $2 \mathrm{~mL}$ of pancreatin solution $(100 \mathrm{U} / \mathrm{mL})$ and $1 \mathrm{~mL}$ of bile salts $(10 \mathrm{mM})$ were added to the mixture; thus, tubes were incubated at the same condition described, completing $240 \mathrm{~min}$ of the assay. Samples were withdrawn in times 30, 60, and $120 \mathrm{~min}$, referring to the SGF, and 130, 180, and $240 \mathrm{~min}$, referring to the SIF, for the quantification of TPC and TC as described in sections 3.2.2.1 and 3.2.2.2, respectively. Results were expressed as a percentage of total phenolic compounds and total carotenoids released in simulated gastrointestinal fluids (Eq. 3). Also, the evaluation of probiotics viability during in vitro digestion was performed by enumeration (section 3.2.2.5). Also, The samples were also observed using an optical Microscope (DM500, Leica Microsystems GmbH, Germany) with an objective of 10x.

$$
\text { Release }(\%)=\left(\frac{\text { Amount of bioactive released in simulated gastrointestinal fluid }}{\text { Amount of bioactive in microcapsules }}\right) \times 100 \text { Eq. (3) }
$$




\subsection{RESULTS AND DISCUSSION}

\subsubsection{Antioxidant activity of guaraná extracts}

Antioxidant activities of the guaraná extracts can be seen in Table 3. GSE presented the highest antioxidant for all tests performed when compared to GPE values. This result can be correlated with the higher content of phenolic compounds found in guaraná seeds, such as catechins (SILVA et al., 2019). Despite the fact that GPE showed less antioxidant potential, its application in food products is an interesting approach not only as a color additive due to the presence of carotenoids but also for the sustainability of using this food by-product.

Santana and Macedo (2019) reported higher values in the analysis of DPPH antioxidant activity for GSE, approximately 25,000 $\mu \mathrm{mol}$ eq. Trolox/g. However, this difference probably occurred due to the origin of the guaraná used in the experiments (Maués, Amazônia) and the different extraction conditions.

Kang et al. (2012) verified that antioxidant activities of the açaí pulp, which is another superfruit from the Amazon region, by the ORAC and DPPH methods were approximately 7,700 $\mu \mathrm{mol}$ eq. Trolox/g and $320 \mu \mathrm{mol}$ eq. Trolox/g, respectively. Another study evaluated the antioxidant activity of 30 water plant extracts, showing that cinnamon extract (Cinnamomum zeylanicum) showed high antioxidant activity in most of the methods employed (DUDONNÉ et al., 2009). The authors reported that the antioxidant activity of cinnamon extract by ORAC was approximately $8,500 \mu \mathrm{mol}$ eq. Trolox/g. In this way, GSE showed upper antioxidant potential than açaí pulp and watery extract of cinnamon.

Hence, the GSE has a high antioxidant potential to be used in food systems. This result was already expected, considering the content of catechins present in the extract. In addition, Grzesik et al. (2018) demonstrated that catechins have a high sequestering capacity for the ABTS radical compared to other flavonoids. However, the authors indicated that these compounds displayed a low bioavailability. Thus, encapsulation could be an alternative to solve this problem.

\subsubsection{Antimicrobial activity and effect of guaraná extracts in the multiplication of probiotics}

The antimicrobial activity of guaraná extracts against the studied probiotics, L. paracasei BGP-1 and B. animalis subsp. lactis BLC-1 was carried out using the agar diffusion technique. Guaraná extracts did not show inhibitory activity for both probiotics at the concentration of GSE that ranged from 130 to $520 \mathrm{mg} \mathrm{GAE} / \mathrm{mL}$ and GPE varied from 55 to $222 \mu \mathrm{g}$ carotenoids $/ \mathrm{mL}$. 
Table 3 - Antioxidant activity of guaraná seeds extract (GSE) and guaraná peels extract (GPE).

\begin{tabular}{cccc}
\hline Extract & $\begin{array}{c}\text { DPPH }(\mu \text { mol eq. de } \\
\text { Trolox/g) }\end{array}$ & $\begin{array}{c}\text { ABTS }(\mu \text { mol eq. de } \\
\text { Trolox/g) }\end{array}$ & $\begin{array}{c}\text { ORAC }(\mu \mathrm{mol} \text { eq. de } \\
\text { Trolox/g })\end{array}$ \\
\hline GSE & $3,218 \pm 50^{\mathrm{A}}$ & $9,534 \pm 70^{\mathrm{A}}$ & $11,293 \pm 14^{\mathrm{A}}$ \\
GPE & $22 \pm 2^{\mathrm{B}}$ & $68 \pm 2^{\mathrm{B}}$ & $127 \pm 6^{\mathrm{B}}$
\end{tabular}

Values are mean \pm standard error (SE) ( $\mathrm{n}=4$ analytical replicates). Values with the same upper case letter in a column are not statistically different $(\mathrm{p}>0.05)$. Reference: Own source.

Another study reported that guaraná extract exhibited inhibitory activity for Pseudomonas aeruginosa and Escherechia coli, which are two pathogenic and undesirable bacteria in food production (BASILE et al., 2005). However, no other study evaluated the antimicrobial activity of guaraná extracts against probiotics. Similarly, Marinho et al. (2019) reported that jussara pulp did not show the inhibitory activity of the jussara pulp against Lactobacillus acidophilus LA3 and $L$. paracasei BGP-1, even with the high content of phenolics and anthocyanins in its composition. Furthermore, food matrices that are sources of phenolic compounds, such as semisweet chocolate, maintained the viability of probiotics during the storage, proving to be an excellent product for adding probiotics (SILVA et al., 2017).

Table 4 displays the enumeration of probiotics in MRS broth (control) and MRS broth supplemented with different concentrations of guaraná extracts, evaluating their effect on the multiplication of probiotics under conditions of prolonged incubation. Regarding L. paracasei in the presence of MRS broth without extract, its populations were reduced by approximately $1.5 \log$ $\mathrm{CFU} / \mathrm{mL}$ after $96 \mathrm{~h}$ of incubation at $37^{\circ} \mathrm{C}$. However, the L. paracasei population grown in MRS broth containing 10\% of GPE showed a significant increase when incubated for $96 \mathrm{~h}$. On the other hand, the counts of L. paracasei in MRS broth containing GSE were similar to that one found for L. paracasei in MRS broth without extract.

The growth of $B$. animalis subsp. lactis BLC-1 in MRS broth without extract was not efficient to maintain its population during the prolonged incubation. However, $10 \%$ and $20 \%$ of GPE stimulated the probiotics population, obtaining the highest count after the incubation time of $96 \mathrm{~h}$. In contrast, the counts of probiotic population in the presence of GSE were maintained until $72 \mathrm{~h}$ of incubation. 
The different chemical compositions of GSE and GPE are correlated with these findings. GSE is a source of catechins and procyanidins (SILVA et al., 2019). In contrast, GPE contains carotenoids, such as lutein and beta-carotene (PINHO et al., 2021), and the addition of sunflower oil to GPE provides tocopherols, albeit in a small quantity. The antioxidant action of phenolics and carotenoids differs, which could explain the differences in the growth of probiotics. In addition, it is essential to highlight the presence of sunflower oil in GPE, albeit in a small quantity, which could also contribute to probiotic survivability due to the presence of tocopherols.

Furthermore, some studies asserted that the effect of phenolic compounds in the growth of probiotics depends on the probiotic strains, the chemical structure of polyphenols, and concentration (CAMPOS; COUTO; HOGG, 2003), which can explain the difference found during the growth of probiotics.

Similar results were noticed by Hervert-Hernández et al. (2009) that evaluated the effect of pomace grape extract on the multiplication of Lactobacillus acidophilus CECT 903, reporting a significant increment of probiotics population in the presence of extract. In addition, the authors investigated the effect of pure catechin (standard), verifying that a concentration upper to 96 $\mathrm{mg} / \mathrm{mL}$ must cause the stimulatory effect. In this way, atomized GSE showed around $130 \mathrm{mg}$ of catechins/g of powder (SILVA et al., 2019), which probably positively influenced the multiplication of probiotics.

There is a lack of studies that evaluated the influence of carotenoids on probiotic multiplication. For example, GPE showed a positive effect on the multiplication of the probiotics population during the incubation, but other compounds extracted could influence the growth. On the other hand, GSE was pertinent on the increment of probiotics population during the incubation time of $24 \mathrm{~h}$, after it maintained its population until $72 \mathrm{~h}$ of incubation. Based on these promising results, besides the differences in each extract's chemical composition, their stimulatory mechanisms may probably differ, and further studies should be performed to comprehend this influence.

\subsubsection{Hydrophobicity of probiotics}

The comprehension of the physical-chemical properties of the probiotic cell wall is relevant because hydrophobic cells present high adhesion capacity to the intestine (RIJNAARTS et al., 
1993) and can affect the attachment probiotic in microcapsules depending on the encapsulating materials applied for this.

Results related to the hydrophobicity of studied probiotics are shown in Figure 6. Among the probiotics activated in control MRS broth, L. paracasei BGP-1 was the most hydrophobic cell (48\%), compared with B. animalis subsp. lactis BLC-1 (25\%). In this context, correlating the characteristics of encapsulant materials, probably L. paracasei would be better entrapped or immobilized into a lipid matrix, while $B$. animalis subsp. lactis may be protected in hydrophilic polymers matrix. However, both could be encapsulated in amphiphilic substances, such as proteins, Arabic gum, modified starches, and others.

Figure 6 - Hydrophobicity of probiotics cultured in MRS broth or supplemented MRS broth with 10\% (v/v) of guaraná seeds extract (GSE), or guaraná peels extract (GPE).

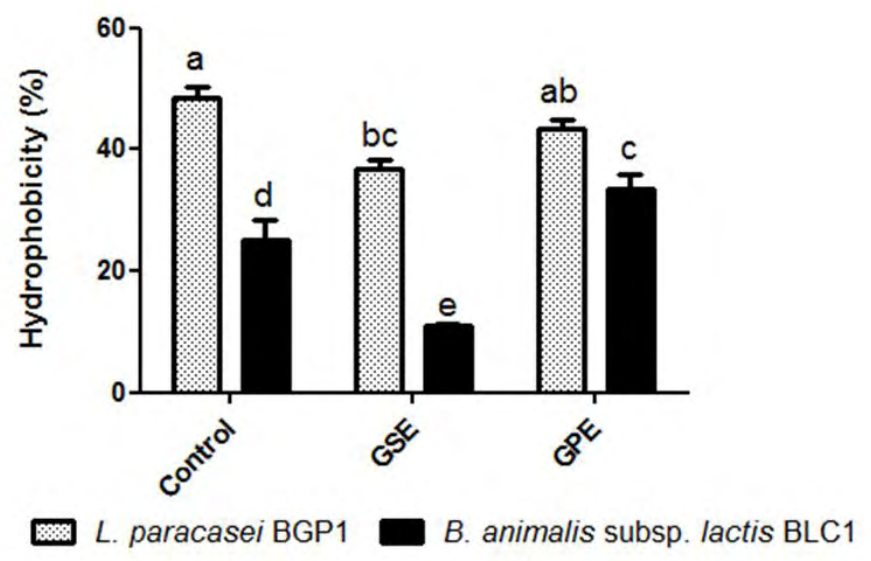

Values are mean \pm standard error (SE) ( $n=3$ analytical replicates). Bars with the same lower case letter in a column are not statistically different $(\mathrm{p}>0.05)$. Reference: Own source.

Holkem et al. (2020) investigated the hydrophobicity of the same probiotic strains, reporting values around $29 \%$ and $37 \%$ for L. paracasei and B. animalis subsp. lactis, respectively. The differences in hydrophobicity found in this study may be correlated with the incubation time of probiotic strains in MRS broth, control of the temperature, and media $\mathrm{pH}$.

The same microorganisms grown in the presence of the GSE showed less affinity by nhexadecane, considering the low hydrophobicity values. On the other hand, the incubation in broth supplemented with GPE increased the hydrophobicity of the B. animalis subsp. lactis BLC-1. Therefore, the supplementation of guaraná extracts in MRS broth during the growth of probiotics affected the hydrophobicity of cells, which can interfere in the efficiency of encapsulation and the attachment of probiotics in the gut for temporary colonization. 
Table 4 - Enumeration of L. paracasei BGP-1 (LP) and B. animalis subsp. lactis BLC-1 (B) populations cultured in MRS broth (control) and MRS broth supplemented by guaraná seed extract (GSE) and guaraná peel extract (GPE), expressed as log CFU/mL.

\begin{tabular}{|c|c|c|c|c|c|c|c|}
\hline Time & Control & $5 \%$ GSE & $10 \%$ GSE & $20 \%$ GSE & $5 \% \mathrm{GPE}$ & $10 \% \mathrm{GPE}$ & $20 \%$ GPE \\
\hline \multicolumn{8}{|c|}{ L. paracasei BGP-1 (LP) } \\
\hline $0 \mathrm{~h}$ & $5.65 \pm 0.07^{\mathrm{Ad}}$ & $5.34 \pm 0.12^{\mathrm{Ac}}$ & $5.54 \pm 0.09^{\mathrm{Ac}}$ & $5.89 \pm 0.27^{\mathrm{Ac}}$ & $6.22 \pm 0.37^{\mathrm{Ab}}$ & $5.95 \pm 0.07^{\mathrm{Ab}}$ & $6.07 \pm 0.32^{\mathrm{Ac}}$ \\
\hline $24 \mathrm{~h}$ & $8.82 \pm 0.31^{\mathrm{Aa}}$ & $9.07 \pm 0.16^{\mathrm{Aa}}$ & $9.00 \pm 0.06^{\mathrm{Aa}}$ & $8.74 \pm 0.06^{\mathrm{Aa}}$ & $8.83 \pm 0.02^{\mathrm{Aa}}$ & $8.59 \pm 0.27^{\mathrm{Aa}}$ & $8.61 \pm 0.52^{\text {Aab }}$ \\
\hline $48 \mathrm{~h}$ & $8.54 \pm 0.09^{\mathrm{Aab}}$ & $8.85 \pm 0.21^{\mathrm{Aa}}$ & $8.72 \pm 0.34^{\mathrm{Aa}}$ & $9.05 \pm 0.14^{\mathrm{Aa}}$ & $7.91 \pm 1.17^{\mathrm{Aab}}$ & $8.85 \pm 0.21^{\mathrm{Aa}}$ & $9.06 \pm 0.08^{\mathrm{Aa}}$ \\
\hline $72 \mathrm{~h}$ & $8.06 \pm 0.03^{\mathrm{Ab}}$ & $7.84 \pm 0.09^{\mathrm{ABb}}$ & $7.66 \pm 0.11^{\mathrm{ABb}}$ & $7.92 \pm 0.11^{\mathrm{ABb}}$ & $7.92 \pm 0.02^{\mathrm{ABab}}$ & $7.93 \pm 0.12^{\mathrm{ABab}}$ & $8.06 \pm 0.05^{\mathrm{Aab}}$ \\
\hline $96 \mathrm{~h}$ & $7.41 \pm 0.02^{\mathrm{Ac}}$ & $7.54 \pm 0.09^{\mathrm{Ab}}$ & $7.63 \pm 0.21^{\mathrm{Ab}}$ & $7.77 \pm 0.10^{\mathrm{Ab}}$ & $7.50 \pm 0.28^{\mathrm{Aab}}$ & $8.44 \pm 1.04^{\mathrm{Aa}}$ & $7.63 \pm 0.22^{\mathrm{Ab}}$ \\
\hline \multicolumn{8}{|c|}{ B. animalis subsp. lactis BLC-1 (B) } \\
\hline $0 \mathrm{~h}$ & $6.11 \pm 0.10^{\mathrm{Ac}}$ & $6.18 \pm 0.26^{\mathrm{Ac}}$ & $6.14 \pm 0.13^{\mathrm{Ac}}$ & $6.02 \pm 0.25^{\mathrm{Ac}}$ & $6.22 \pm 0.09^{\mathrm{Abc}}$ & $6.09 \pm 0.06^{\mathrm{Ab}}$ & $6.16 \pm 0.06^{\mathrm{Aa}}$ \\
\hline $24 \mathrm{~h}$ & $8.16 \pm 0.02^{\mathrm{Aa}}$ & $8.42 \pm 0.03^{\mathrm{Aa}}$ & $8.36 \pm 0.05^{\mathrm{Aa}}$ & $8.19 \pm 0.02^{\text {Aab }}$ & $7.51 \pm 0.05^{\mathrm{Aab}}$ & $6.04 \pm 0.62^{\mathrm{Bb}}$ & $6.35 \pm 0.18^{\mathrm{Ba}}$ \\
\hline $48 \mathrm{~h}$ & $8.31 \pm 0.11^{\mathrm{Aa}}$ & $8.19 \pm 0.02^{\mathrm{Aa}}$ & $8.21 \pm 0.24^{\mathrm{Aa}}$ & $8.59 \pm 0.16^{\mathrm{Aa}}$ & $8.86 \pm 0.68^{\mathrm{Aa}}$ & $5.81 \pm 0.05^{\mathrm{Bb}}$ & $6.22 \pm 0.54^{\mathrm{Ba}}$ \\
\hline $72 \mathrm{~h}$ & $8.36 \pm 0.15^{\mathrm{ABa}}$ & $8.22 \pm 0.06^{\mathrm{ABa}}$ & $8.77 \pm 0.10^{\mathrm{Aa}}$ & $8.36 \pm 0.08^{\mathrm{ABa}}$ & $7.80 \pm 0.02^{\mathrm{ABa}}$ & $6.35 \pm 0.06^{\mathrm{Bb}}$ & $7.22 \pm 1.48^{\mathrm{ABa}}$ \\
\hline $96 \mathrm{~h}$ & $7.27 \pm 0.18^{\mathrm{BCb}}$ & $7.57 \pm 0.10^{\mathrm{ABb}}$ & $7.58 \pm 0.03^{\mathrm{ABb}}$ & $7.77 \pm 0.08^{\mathrm{ABb}}$ & $6.00 \pm 0.31^{\mathrm{Cc}}$ & $8.98 \pm 0.28^{\mathrm{Aa}}$ & $8.16 \pm 0.87^{\mathrm{ABa}}$ \\
\hline
\end{tabular}

Values are mean \pm standard error (SE) ( $n=3$ analytical replicates). Values with the same upper case letter in a row and values with the same lower case letter in a column are not statistically different $(\mathrm{p}>0.05)$. Reference: Own source. 


\subsubsection{Characterization of microcapsules: morphology and particle size}

Figure 7 displays the morphology of the coacervates, as well as the aspect of powders obtained after freeze-drying. All formulations studied resulted in coacervates with a spherical shape and defined walls, due to the electrostatic interaction between gelatin and gum Arabic. Besides that, coacervates containing probiotics and coacervates containing probiotics and GSE were treated with a live/dead cell viability kit, distinguishing live, compromised membrane and dead cells. Changes of probiotic viability can be related to experimental parameters used in microencapsulation, such as mechanical stress, harmful temperature, $\mathrm{pH}$, etc. In this context, live and dead cells fluoresce as blue and red, respectively. Probiotics entrapped in control coacervates exhibited few red cells and mainly blue cells, indicating the presence of non-viable and viable probiotics. This finding was expected since probiotic cells are very sensitive. For example, Silva et al. (2018) reported a reduction of probiotic viability, around $2 \log \mathrm{CFU} / \mathrm{g}$, after microencapsulation by complex coacervation. Concerning the co-encapsulation of probiotic and GSE, it was noticed mainly blue cells entrapped in this coacervate and outside. It is worth emphasizing that probiotics were also observed outside the coacervates for all samples, even if they were stood out only in the coacervate containing probiotics and GSE.

In contrast, GPE was previously stained with Nile Red instead of live/dead cell viability kit to verify the microencapsulation of lipid extract. In this way, the red droplets inside the coacervates in Figure 7 (B) confirms the entrapment of GPE. Also, probiotics were not evidenced in this image since this coacervate was not treated with live/dead viability kit.

These results are supported by other studies that encapsulated probiotics by complex coacervation and used a high melting point vegetable fat as a core (HOLKEM; FAVAROTRINDADE, 2020; SILVA et al., 2018). Lipids enhanced the attachment of probiotics in the core of coacervates, which could increase the protection of probiotic cells by the double layer of polymers. However, the application of lipids in coacervates is limited since they can alter the sensory attributes of food matrices. 
Figure 7 - Confocal microscopy of coacervates (A, B, C), followed by the aspect of powders after freezedrying (D, E, F) and their micrographs by scanning electron microscopy $(\mathrm{G}, \mathrm{H}, \mathrm{I})$. In this figure: A, D, G are coacervates containing probiotic (control), B, E, H are coacervates containing probiotic and guaraná peel extract (GPE), C, F, I are coacervates containing probiotic and guaraná seed extract (GSE).

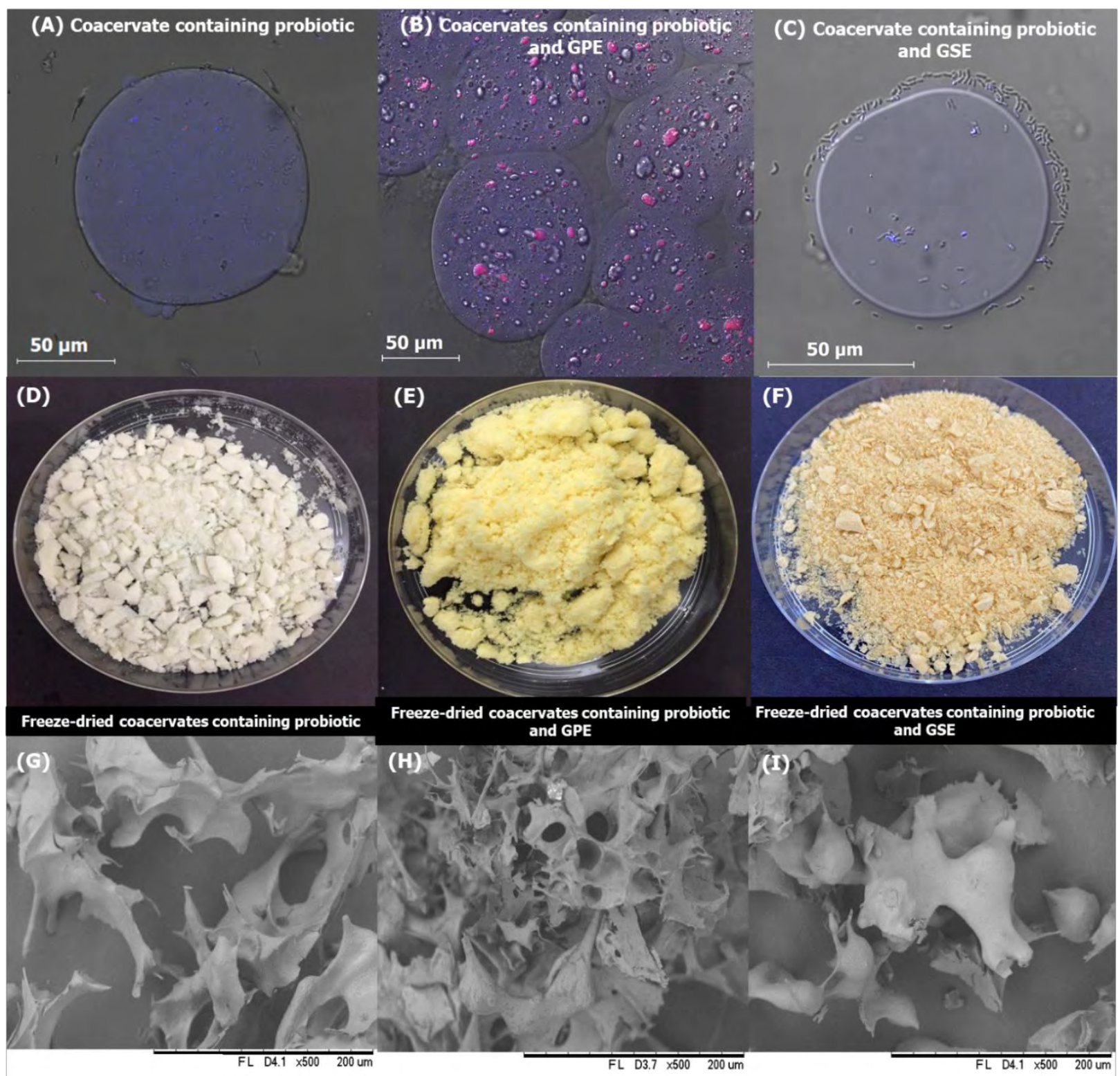

Reference: Own source.

Wet coacervates loaded with L. paracasei BGP-1 or B. animalis subsp. lactis BLC-1 had particle sizes of $108.33 \pm 0.10$ and $131.03 \pm 0.15 \mu \mathrm{m}$, respectively (Table 5). On simultaneous loading of the same probiotics and GSE, coacervates maintained their average particle size (112.46 
\pm 0.31 and $129.46 \pm 0.26 \mu \mathrm{m}$, respectively). However, the particle sizes of coacervates containing GPE and L. paracasei BGP-1 or B. animalis subsp. lactis BLC-1 were increased significantly: $141.42 \pm 0.13$ and $139.18 \pm 0.12 \mu \mathrm{m}$, respectively. Thus, the particle size of wet coacervates ranged from 108 to $141 \mu \mathrm{m}$, showing potential for application as supplements in food. Although the desirable size for microcapsules for application in food matrices is above $100 \mu \mathrm{m}$, to preserve their textural and sensory properties (COMUNIAN et al., 2017), the application of microcapsules with an average size of $140 \mu \mathrm{m}$ in yogurt did not affect the consumers' sensory perception (SILVA et al., 2022). Other possibilities for the incorporation of larger particles are solid food matrices, such as cereal bars, peanut butter, and chocolate, since their composition and texture could be favorable to mask them.

In order to improve the viability of probiotics during storage, all coacervates were freezedried. Figure 7 shows the aspect of powders, presenting aggregation, which is typical of freezedried materials. Furthermore, GPE and GSE provided the powders with yellowish and brownish colors, due to the presence of carotenoids and phenolic compounds, respectively.

\subsubsection{Enumeration of probiotics and evaluation of total phenolic content and total carotenoids after encapsulation}

Initial enumerations of L. paracasei and B. animalis subsp. lactis were $10.0 \pm 0.2$ and 9.9 $\pm 0.4 \log \mathrm{CFU} / \mathrm{g}$ of inoculum (data not shown). Depending on the formulation of freeze-dried coacervates, the final counts ranged from 7.7 to $9.1 \mathrm{log}$ CFU/g (Table 5), demonstrating that complex coacervation and freeze-drying were mild processes since the reduction of probiotic populations varied from 2 to $1 \log \mathrm{CFU} / \mathrm{g}$. The simultaneous loading of GPE and probiotics in coacervates provided greater viability of probiotics after encapsulation and freeze-drying processes, which could be correlated with their prebiotic potential as mentioned before. On the other hand, the concentration of GSE applied in coacervates loaded with probiotics did not enhance the resistance of probiotics to the process of encapsulation and dehydration since the counts were similar to the control formulations (without guaraná extracts).

Regarding the total phenolic content in microcapsules, values were around $54 \mathrm{mg} \mathrm{GAE} / \mathrm{g}$ of the microcapsule. Another study encapsulated cinnamon extract simultaneously with probiotic 
Table 5 - Characterization of microcapsules containing probiotics L. paracasei BGP-1 (LP) or B. animalis subsp. lactis BLC-1 (B), or microcapsules loaded simultaneously with probiotic and guaraná seed extract (GSE) or guaraná peel extract (GPE). Microcapsules were evaluated regarding the enumeration of probiotics after freeze-drying, total phenolic content (TPC), total carotenoids (TC) and average size.

\begin{tabular}{|c|c|c|c|c|c|c|}
\hline Parameters & $\begin{array}{l}\text { Microcapsule } \\
\text { loaded with } \\
\text { LP }\end{array}$ & $\begin{array}{c}\text { Microcapsule } \\
\text { loaded with LP } \\
\text { and GSE }\end{array}$ & $\begin{array}{c}\text { Microcapsule } \\
\text { loaded with LP } \\
\text { and GPE }\end{array}$ & $\begin{array}{l}\text { Microcapsule } \\
\text { loaded with B }\end{array}$ & $\begin{array}{l}\text { Microcapsule } \\
\text { loaded with B } \\
\text { and GSE }\end{array}$ & $\begin{array}{c}\text { Microcapsule } \\
\text { loaded with B } \\
\text { and GPE }\end{array}$ \\
\hline $\begin{array}{c}\text { Enumeration of } \\
\text { probiotics (log } \\
\text { CFU/g of } \\
\text { microcapsule) }\end{array}$ & $8.33 \pm 0.13^{\mathrm{bc}}$ & $8.54 \pm 0.08^{\mathrm{bc}}$ & $8.71 \pm 0.05^{\mathrm{ab}}$ & $8.13 \pm 0.07^{\mathrm{cd}}$ & $7.73 \pm 0.18^{d}$ & $9.12 \pm 0.16^{\mathrm{a}}$ \\
\hline $\begin{array}{c}\text { TPC (mg GAE/g of } \\
\text { microcapsule) }\end{array}$ & - & $54.73 \pm 3.21^{\mathrm{a}}$ & - & - & $52.94 \pm 4.26^{\mathrm{a}}$ & - \\
\hline $\begin{array}{c}\mathrm{TC}(\mu \mathrm{g} \\
\text { carotenoids/g of } \\
\text { microcapsule })\end{array}$ & - & - & $37.67 \pm 1.27^{\mathrm{b}}$ & - & - & $43.03 \pm 2.40^{\mathrm{a}}$ \\
\hline Average size $(\mu \mathrm{m})$ & $108.33 \pm 0.10^{c}$ & $112.46 \pm 0.31^{\mathrm{c}}$ & $141.42 \pm 0.13^{\mathrm{a}}$ & $131.03 \pm 0.15^{\mathrm{b}}$ & $129.46 \pm 0.26^{\mathrm{b}}$ & $139.18 \pm 0.12^{\mathrm{a}}$ \\
\hline
\end{tabular}


cells by complex coacervation, reporting the total phenolic content from 33 to $83 \mathrm{mg} \mathrm{GAE} / \mathrm{g}$ of microcapsules, depending on the proportion of cinnamon extract added in the formulation of microcapsules (HOLKEM et al., 2020).

Total carotenoids in microcapsules varied from 38 to $43 \mu \mathrm{g}$ of carotenoids/g, while the total carotenoids found in GPE was around $235 \mu \mathrm{g}$ of carotenoids/g. Dima et al. (2021) recovered the carotenoids from tomato peels and encapsulated them by complex coacervation. Authors reported that total carotenoids in microcapsules were around $44 \mathrm{mg} / \mathrm{g}$, considering that tomato peels extract showed $261 \mathrm{mg}$ of carotenoids/g. In this way, as expected, the source for extraction of carotenoids affects the total carotenoids content of microcapsules.

\subsubsection{Release of encapsulated probiotics in simulated gastrointestinal fluids}

Microencapsulation is a potential technology to improve probiotic survivability during harsh conditions. For instance, other studies reported a significant reduction of final counts, around 4-5 $\log$ CFU/g, for unencapsulated B. animalis subsp. lactis BLC-1 and L. paracasei BGP-1 in simulated gastrointestinal fluids (HOLKEM; FAVARO-TRINDADE; LACROIX, 2020; MATOS-JR et al., 2019; SILVA et al., 2017). In this sense, microencapsulation is required to increase the preservation of probiotic viability during in vitro digestion tests. Furthermore, efficient microcapsules protect probiotics in harsh conditions but release them into the intestine for colonization. Most studies about the encapsulation of probiotics investigate the release or survival of probiotics in simulated gastrointestinal fluids. A release study evaluates the viable probiotics released into simulated gastrointestinal fluids, while a survival study also verifies the viable probiotics that remain in microcapsules. Figure 8 displays the release of probiotics in simulated gastrointestinal fluids, expressed as a percentage. Initially, the counts for freeze-dried coacervates loaded with probiotics were around $8.5 \log \mathrm{CFU} / \mathrm{g}$.

All coacervates released around $45 \%$ of probiotic cells at the beginning of the in vitro digestion test, which can be correlated with the probiotics attached to the surface of coacervates or the early release of probiotics due to their hydrophilicity. In addition, according to the composition of SGF, low $\mathrm{pH}$ and pepsin may facilitate the release of probiotics, as demonstrated by the increment of viable probiotics in SGF after $120 \mathrm{~min}$ of the in vitro test. For instance, control 
coacervates loaded with $B$. animalis subsp. lactis showed the maximum percentage of release, around $75 \%$, at $120 \mathrm{~min}$. However, coacervates loaded with GPE showed a lower release of probiotics in SGF, demonstrating that GPE probably enhanced the entrapment of probiotic cells in coacervates. Thus, producing a previous emulsion containing probiotics may reduce this premature release of probiotics in SGF.

Figure 8 - Figure 3 - Release of probiotics in simulated gastric fluid (SGF) for $120 \mathrm{~min}$, sequentially added to the simulated intestinal fluid (SIF) until complete $240 \mathrm{~min}$ of the assay, expressed as percentages (\%), considering the initial number of viable cells in coacervates. In this Figure: the black line is the control coacervate loaded with $L$. paracasei BGP-1 (LP); the brown line is the coacervate loaded with LP and guaraná seed extract (GSE); the blue line is the control coacervate loaded with B. animalis subsp. lactis BLC-1 (B); the red line is the coacervate loaded with B and guaraná peel extract (GPE).

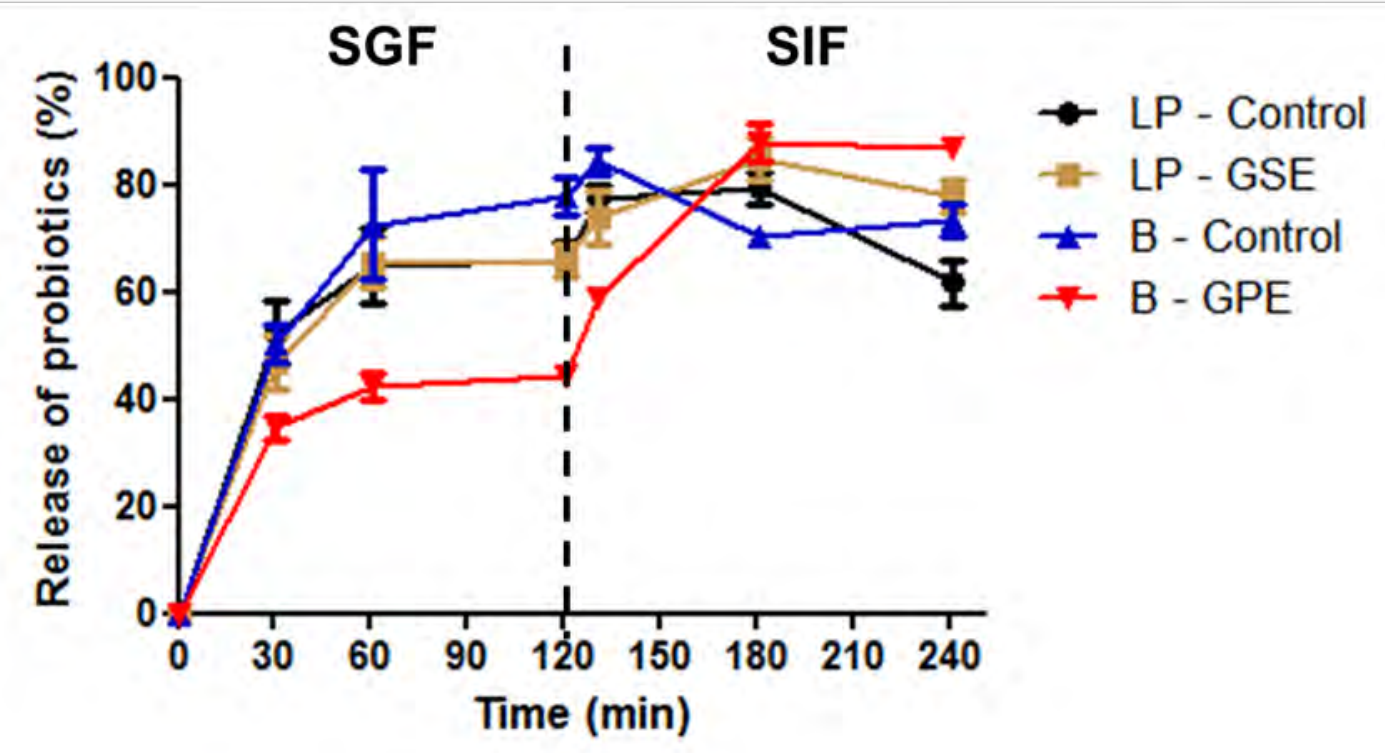

Values are mean \pm standard error (SE) ( $\mathrm{n}=3$ analytical replicates). Reference: Own source.

There was a similar probiotic release for coacervates loaded with only L. paracasei BGP1 (LP - Control) and coacervates loaded simultaneously with L. paracasei BGP-1 and GSE at the end of SGF. In this context, a fast release of probiotics in SGF is not desirable since it could cause probiotic death by the harsh conditions. However, the presence of phenolic compounds from GSE could be positive about maintaining the viability of prematurely released probiotics in the middle, indicating a potential advantage of co-encapsulating probiotics with phenolic compounds from plant extracts.

Among the formulations, coacervates loaded with GPE showed a gradual release in simulated gastrointestinal fluids, increasing after applying SIF. The $\mathrm{pH}$ adjustment to 7 in SIF, 
pancreatin, and bile salts may have contributed to the complete dissociation of polymers, delivering the probiotics with more affinity with GPE. In this way, the association of carotenoidrich extract with probiotics in coacervates was adequate to increase the number of probiotic cells reaching the intestinal phase.

The final release of probiotics was at least 60\% in SIF, as can be seen in Figure 3. Among the coacervates studied, the final counts of probiotics simultaneously encapsulated with guaraná extracts were higher, about 6.5 to $7.2 \log \mathrm{CFU} / \mathrm{mL}$. In contrast, the final counts of probiotics released by control coacervates were 5 to $6 \log \mathrm{CFU} / \mathrm{mL}$. For this reason, the co-encapsulation of probiotic and guaraná extracts clearly preserved the viability of probiotics in simulated gastrointestinal fluid. One possible explanation is that the physical-chemical characteristics of guaraná extracts could delay the release of probiotics, probably because bioactive compounds (e.g., phenolics) interacted with the polymers that constitute the coacervates, fortifying their structure. Another study demonstrated that phenolic compounds from GSE may inhibit enzymes, which may favor the probiotic survivability in this middle (Silva et al., 2019). However, further studies evaluating the antioxidant capacity of encapsulated bioactive compounds in simulated gastrointestinal fluids could elucidate the role of phenolics and carotenoids in decreasing the oxidative stress of probiotics.

\subsubsection{Release of phenolic compounds and carotenoids in simulated gastrointestinal fluids}

Figure 9 illustrates the release of phenolic compounds (A) and carotenoids (B) in simulated gastrointestinal fluids, as well as the micrographs obtained during the in vitro assay. The cumulative release of phenolic compounds in SGF was around 60\%, proving their fast release at low $\mathrm{pH}$ and susceptibility of hydrophilic materials encapsulated by complex coacervation. Also, micrographs exhibited the aggregation of coacervates containing GSE in SGF, but the integrity of coacervates was maintained. In this way, the premature release of phenolic compounds from GSE can be correlated with their attachment on the surface of coacervates, facilitating the quick release. Although micrographs could reveal interesting aspects of microcapsules during in vitro digestion tests, few studies evaluated the modifications of the morphology of coacervates by optical microscopy (SOUZA et al., 2019; HOLKEM et al., 2020). 
The microencapsulation of GSE is relevant since another study reported that phenolic compounds from free GSE were sensitive in SGF during in vitro digestion (SILVA et al., 2019). Furthermore, after the microencapsulation of GSE by spray chilling using vegetable fat, the resulting lipid particles were highly hydrophobic and reduced the quick release of phenolic compounds in SGF (SILVA et al., 2019). Similarly, phenolics from cinnamon extract coencapsulated with probiotics by complex coacervation using vegetable fat, whey protein concentrate, and gum Arabic were mainly released in SIF (HOLKEM et al., 2020), indicating the beneficial role of lipids for controlled release of phenolics. Thus, the production of a previous emulsion of GSE or its immobilization in vegetable fat could protect phenolics in SGF and control their release in SIF.

Differently, coacervates loaded with carotenoids from GPE showed a lower release of carotenoids, about $13 \%$ in SGF. The composition of SGF with low $\mathrm{pH}$ and pepsin solution did not trigger the release of carotenoids, maintaining GPE entrapped in coacervates. This finding was confirmed by optical microscopy since most of the coacervates were intact, as seen by the welldelimited edges around the yellow multinucleate. In this sense, complex coacervation was efficient to protect GPE in SGF, proving to be an excellent encapsulation technique for protecting lipophilic compounds. Similar results were reported by Neagu et al. (2020), who encapsulated oleoresin extract from sea buckthorn by complex coacervation, showing around $9 \%$ release of carotenoids in SGF. Thus, complex coacervation was efficient for preventing the premature release of carotenoids in SGF.

The application of SIF did not significantly affect the release of phenolic compounds from GSE since most phenolics had been released previously, which could make these compounds more susceptible to degradation. However, after the addition of SIF, micrographs displayed an increase in the brownish coloration of the middle. This modification of color in the middle may partly occur due to the addition of pancreatin solution, which has this characteristic color. Additionally, phenolic compounds could interact with the enzymes and bile salts, changing the color of the remaining coacervates to dark brown. Likewise, Souza et al. (2019) evaluated the combination of double emulsion and complex coacervation using gelatin and gum Arabic for encapsulation of lactase, indicating that aggregates at the end of SIF could be an association of digested polymers. 
Another study evaluated the kinetics of release for coacervates loaded with a double emulsion containing anthocyanin extract in simulated gastrointestinal fluids (KANHA et al., 2021). Although freeze-dried coacervates showed a cumulative release of around $40 \%$ of anthocyanins in SGF at $120 \mathrm{~min}$, the application of SIF released about $80 \%$ of anthocyanins (KANHA et al., 2021). These authors indicated an erosion mechanism of release for freeze-dried coacervates.

Concerning the coacervates loaded with GPE, the change of $\mathrm{pH}$ by adding SIF and the bile salts and pancreatin solution facilitated the release of carotenoids. In addition, the choice of gum Arabic, which is known for its emulsifying capacity, as encapsulating material can improve micellization, which is a requested for carotenoids absorption (MONTERO et al., 2016).

These results can be correlated with the micrographs shown in Fig. 9 (B) since the coacervates loaded with GPE displayed their rupture after the addition of SIF by the increase of oil droplets in the middle. Furthermore, the presence of varied oil droplet size at the end of SIF is associated with the action of bile salts and pancreatin, which are responsible for lipid digestion. Similarly, another study reported that SIF was decisive to release bioactive compounds and probiotics from coacervates, confirmed by optical microscopy (HOLKEM et al., 2020).

Based on these results, the chemical characteristics of bioactive compounds and the adjustment of $\mathrm{pH}$ by adding simulated gastrointestinal fluids affected the electrostatic interaction of the polymers, releasing guaraná extracts. Furthermore, gelatin and gum Arabic have a negative charge at $\mathrm{pH} 7$, and repulsive force may dissociate the coacervates. These results are in accordance with Zhou et al. (2018) who reported the dissociation of microcapsules loaded with astaxanthin oleoresin obtained by complex coacervation using whey protein and gum Arabic after a change of $\mathrm{pH}$ and application of digestive enzymes.

At the end of the in vitro digestion test, the total release of carotenoids and phenolic compounds was about $90 \%$ and $80 \%$, respectively, demonstrating that microencapsulation successfully released bioactive compounds from guaraná extract and probiotics in simulated gastrointestinal fluids. In this context, the simultaneous release in the gut could provide synergistic interactions between them, enhancing their health benefits. 
Figure 9 - Micrographs and accumulated release of encapsulated phenolic compounds from GSE (A) and carotenoids from GPE (B) in simulated gastric fluid (SGF) for $120 \mathrm{~min}$, sequentially adding the simulated intestinal fluid (SIF), completing $240 \mathrm{~min}$ of the assay. Values are mean \pm standard error (SE) ( $\mathrm{n}=3$ analytical replicates). Reference: Own source.

\section{(A)}
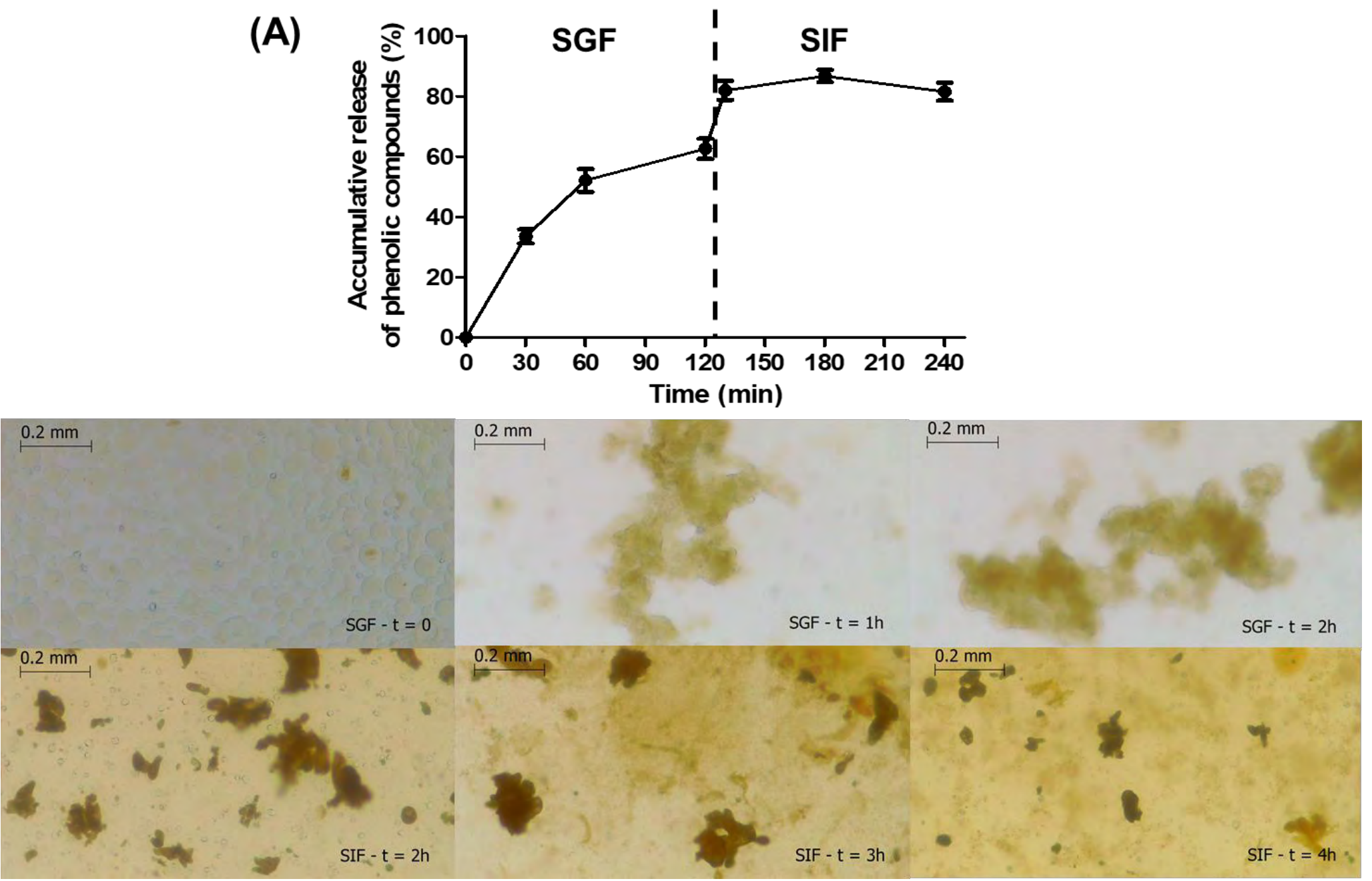
(B)
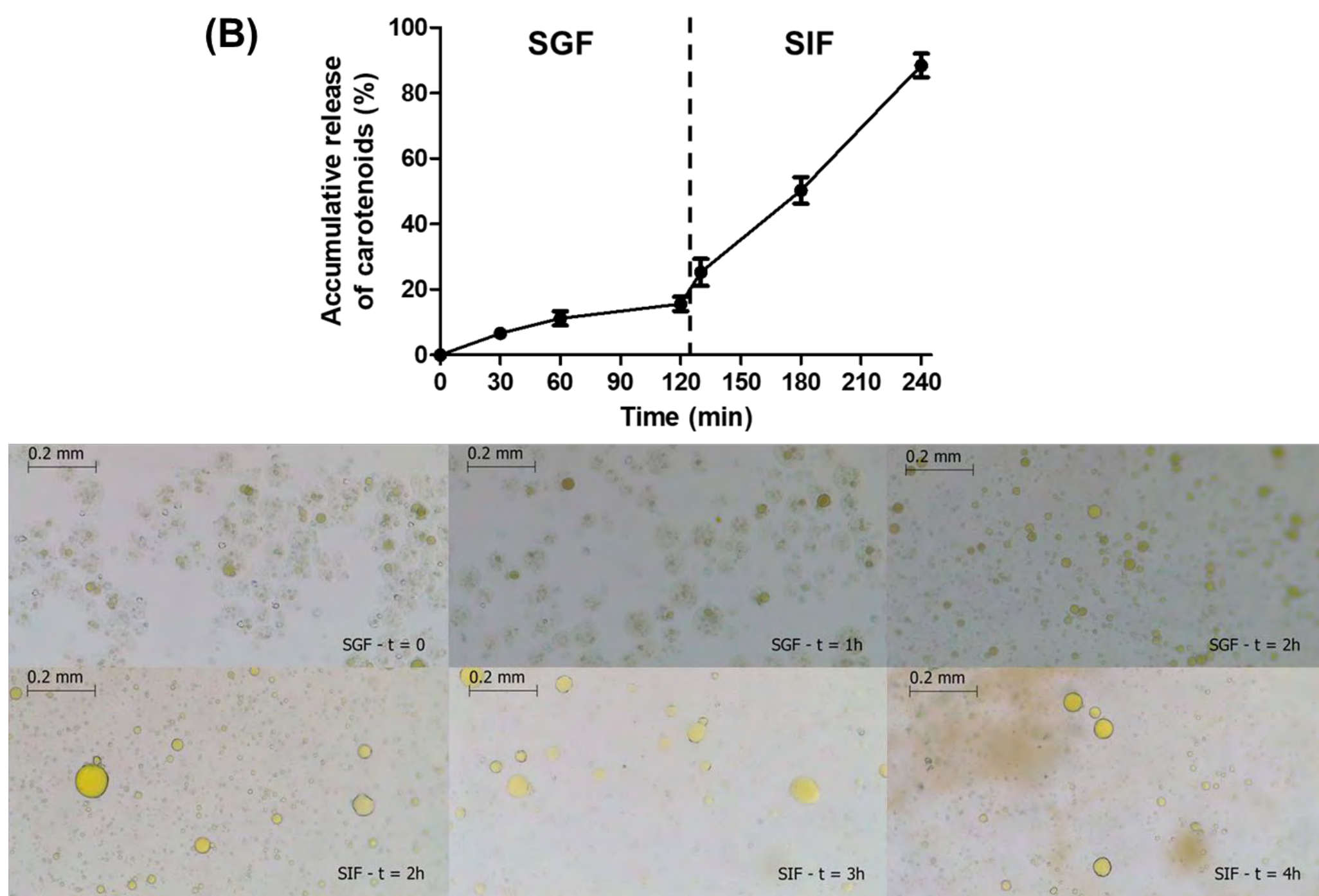


\subsection{CONCLUSIONS}

The use of guaraná seeds and peel to extract bioactive compounds originated two extracts with different chemical profiles and with antioxidant potential. In addition, the supplementation of MRS broth with GPE positively affected the growth of probiotics, demonstrating a potential prebiotic activity of this guaraná by-product. Although coacervates displayed fast release of probiotics and phenolic compounds from GSE in gastric phase, a considerable quantity of phenolics and probiotics reached the intestinal phase. However, complex coacervation protected carotenoids from GPE and probiotics, delaying their release in simulated gastrointestinal fluids. Therefore, co-encapsulation improved the protection of probiotics in simulated gastrointestinal fluids since probiotic counts were higher than for coacervates loaded only with probiotics. Also, these freeze-dried coacervates could be applied in food for supplementation of bioactive compounds and probiotics, providing simultaneous release in simulated gastrointestinal fluids.

\section{ACKNOWLEDGEMENTS}

Authors thanks the São Paulo Research Foundation (FAPESP) for the fellowship awarded to Marluci Palazzolli da Silva (grant \#2016/24895-5 and grant \#2019/09757-3) and Coordenação de Aperfeiçoamento de Pessoal de Nível Superior - Brazil (CAPES) - Finance Code 001. FavaroTrindade also thanks Conselho Nacional de Desenvolvimento Científico e Tecnológico (CNPq) for the productivity grant (Process \#305115/2018-9). Martelli-Tosi also thanks FAPESP (Process \#2019-23171-1).

\section{REFERENCES}

AL-DUAIS, M. et al. Antioxidant capacity and total phenolics of Cyphostemma digitatum before and after processing: use of different assays. European Food Research and Technology, 228, 813-821, 2009.

BASILE, A. et al. Antibacterial and antioxidant activities of ethanol extract from Paullinia cupana Mart. Journal of Ethnopharmacology, v. 102, p. 32-36, 2005. 
CAMPOS, F. M.; COUTO, J. A.; HOGG, T. A. Influence of phenolic acids on growth and inactivation of Oenococcus oeni and Lactobacillus hilgardii. Journal of Applied Microbiology, v. 94, p. 167-174, 2003.

CHINA, R. et al. Antimicrobial activity of Sesbania grandiflora flower polyphenol extracts on some pathogenic bacteria and growth stimulatory effect on the probiotic organism Lactobacillus acidophilus. Microbiological Research, v. 167, p. 500-506, 2012.

COMUNIAN, T. A.; FÁVARO-TRINDADE, C. S. Microencapsulation using biopolymers as an alternative to produce food enhanced with phytosterols and omega-3 fatty acids: A review. Food Hydrocolloids, v. 61, p. 442-457, 2016.

CRUXEN, C. E. S. et al. Probiotic butiá (Butia odorata) ice cream: Development, characterization, stability of bioactive compounds, and viability of Bifidobacterium lactis during storage. LWT - Food Science and Technology, v. 75, p. 379-385, 2017.

DIAS, C. O. et al. Development and physico-chemical characterization of microencapsulated bifidobacteria in passion fruit juice: A functional non-dairy product for probiotic delivery. Food Bioscience, v. 24, p. 26-36, 2018.

DUDONNÉ, S. et al. Comparative Study of Antioxidant Properties and Total Phenolic Content of 30 Plant Extracts of Industrial Interest Using DPPH, ABTS, FRAP, SOD, and ORAC Assays. Journal of Agricultural and Food Chemistry, v. 57, p. 1768-1774, 2009.

ERATTE, D. et al. Co-encapsulation and characterisation of omega-3 fatty acids and probiotic bacteria in whey protein isolate-gum Arabic complex coacervates. Journal of Functional Foods, v. 19, p. 882-892, 2015.

FAVARO-TRINDADE, C. S.; HEINEMANN, R. J. B.; PEDROSO, D. L. Review: Developments in probiotic encapsulation. Perspectives in Agriculture, Veterinary Science, Nutrition and Natural Resources, v.6, p.1-8, 2011.

GAUDREAU, H. et al. Co-encapsulation of Lactobacillus helveticus cells and green tea extract: Influence on cell survival in simulated gastrointestinal conditions. Journal of Functional Foods, v. 26, p. 451-459, 2016. 
GAUDREAU, H. et al. Effect of catechins on the growth of oxygen-sensitive probiotic bacteria. Food Research International, v. 53, p. 751-757, 2013.

GIBSON, G. R. et al. The International Scientific Association for Probiotics and Prebiotics (ISAPP) consensus statement on the definition and scope of prebiotics. Nature Reviews Gastroenterology \& Hepatology, v. 14, p. 491-502, 2017.

GRZESIK, M. et al. Antioxidant properties of catechins: Comparison with other antioxidants. Food Chemistry, v. 241, p. 480-492, 2018.

HERVERT-HERNÁNDEZ, D. et al. Stimulatory role of grape pomace polyphenols on Lactobacillus acidophilus growth. International Journal of Food Microbiology, v. 136, p. 119122, 2009.

HILL, C. et al. The International Scientific Association for Probiotics and Prebiotics consensus statement on the scope and appropriate use of the term probiotic. Nature Reviews

Gastroenterology \& Hepatology, v. 11, p. 506-514, 2014.

HOLKEM, A. T.; FAVARO-TRINDADE, C. S. Potential of solid lipid microparticles covered by the protein-polysaccharide complex for protection of probiotics and proanthocyanidin-rich cinnamon extract. Food Research International, v. 136, 109520, 2020.

KANG, J. et al. Bioactivities of açaí (Euterpe precatoria Mart.) fruit pulp, superior antioxidant and anti-inflammatory properties to Euterpe oleracea Mart. Food Chemistry, v. 133, p. 671677, 2012.

KANHA, N. et al. Properties and kinetics of the in vitro release of anthocyanin-rich microcapsules produced through spray and freeze-drying complex coacervated double emulsions. Food Chemistry, v. 340, 127950, 2021.

KAWABATA, K.; YOSHIOKA, Y.; TERAO, J. Role of Intestinal Microbiota in the Bioavailability and Physiological Functions of Dietary Polyphenols. Molecules, v. 24, p. 370, 2019. 
MAJHENIC, L.; SKERGET, M.; KNEZ, Z. Antioxidant and antimicrobial activity of guaraná seed extracts. Food Chemistry, v. 104, p. 1258-1268, 2007.

MARINHO, J.F.U. et al. Probiotic and Synbiotic Sorbets Produced with Jussara (Euterpe edulis) Pulp: Evaluation Throughout the Storage Period and Effect of the Matrix on Probiotics Exposed to Simulated Gastrointestinal Fluids. Probiotics and Antimicrobial Proteins, v. 11, p. 264-272, 2019.

MATOS-JR, F.E. et al. Evaluation of the viability and the preservation of the functionality of microencapsulated Lactobacillus paracasei BGP1 and Lactobacillus rhamnosus 64 in lipid particles coated by polymer electrostatic interaction. Journal of Functional Foods, v. 54, p. 98$108,2019$.

MELO, P.S. et al. Winery by-products: Extraction optimization, phenolic composition and cytotoxic evaluation to act as a new source of scavenging of reactive oxygen species. Food Chemistry, v. 181, p. 160-169, 2015.

MINEKUS, M. et al. A standardised static in vitro digestion method suitable for food - an international consensus. Food \& Function, 5, 1113-1124, 2014.

MONTERO, P. et al. Microcapsules containing astaxanthin from shrimp waste as potential food coloring and functional ingredient: Characterization, stability, and bioaccessibility. LWT - Food Science and Technology, v. 70, p. 229-236, 2016.

PINHO, L. S. et al. Guaraná (Paullinia cupana) by-product as a source of bioactive compounds and as a natural antioxidant for food applications. Journal of Processing and Preservation, 45, 2021.

RIJNAARTS, H. H. M. et al. Bacterial adhesion under static and dynamic conditions. Applied and Environmental Microbiology, v. 59, p. 3255-3265, 1993. 
SANTANA, A. L.; MACEDO, G. A. Effects of hydroalcoholic and enzyme-assisted extraction processes on the recovery of catechins and methylxanthines from crude and waste seeds of guaraná (Paullinia cupana). Food Chemistry, v. 281, p. 222-230, 2019.

SCHIMPL, F. C. et al. Guaraná: Revisiting a highly caffeinated plant from the Amazon. Journal of Ethnopharmacology, v. 150, p. 14-31, 2013.

SHARIFI, S. et al. Use of whey protein isolate and gum Arabic for the co-encapsulation of probiotic Lactobacillus plantarum and phytosterols by complex coacervation: Enhanced viability of probiotic in Iranian white cheese. Food Hydrocolloids, v. 113, 106496, 2021.

SILVA, M. P. et al. Application of spray chilling and electrostatic interaction to produce lipid microparticles loaded with probiotics as an alternative to improve resistance under stress conditions. Food Hydrocolloids, v. 83, p. 109-117, 2018.

SILVA, M. P. et al. Semisweet chocolate as a vehicle for the probiotics Lactobacillus acidophilus LA3 and Bifidobacterium animalis subsp lactis BLC1: Evaluation of chocolate stability and probiotic survival under in vitro simulated gastrointestinal conditions. LWT - Food Science and Technology, v. 75, p. 640-647, 2017.

SILVA, M. P. et al. Production and characterization of solid lipid microparticles loaded with guaraná (Paullinia cupana) seed extract. Food Research International, v. 123, p. 144-152, 2019.

SINGLETON, V. L.; ORTHOFER, R.; LAMUELA-RAVENTOS, R. M. Analysis of total phenols and other oxidation substrates and antioxidants by means of Folin-ciocalteu reagent. Methods of Enzymology, v. 299, p. 152-178, 1999.

SOUZA, V. B. et al. Microencapsulation by complex coacervation as a tool to protect bioactive compounds and to reduce astringency and strong flavor of vegetable extracts. Food Hydrocolloids, v. 98, 105244, 2020.

SOUZA, C. J. F. et al. Microencapsulation of lactase by W/O/W emulsion followed by ecomplex coacervation: Effects of enzyme source, addition of potassium and core to shell ratio on 
encapsulation efficiency, stability and kinetics of release. Food Research International, v. 121, p. 754-764, 2019.

SOUZA, V. B. et al. Functional properties and encapsulation of a proanthocyanidin-rich cinnamon extract (Cinnamomum zeylanicum) by complex coacervation using gelatin and different polysaccharides. Food Hydrocolloids, v. 77, p. 297-306, 2018.

TIMILSENA, Y. P. et al. Complex coacervation: Principles, mechanisms and applications in microencapsulation. International Journal of Biological Macromolecules, v. 121, p. 12761286, 2019.

VALDÉS, L., et al. The relationship between phenolic compounds from diet and microbiota: impact on human health. Food \& Function, v. 6, p.2424-2439, 2015.

VÁSQUEZ-MALDONADO, D. et al. Preparation of Spray-Dried Functional Food: Effect of Adding Bacillus clausii Bacteria as a Co-Microencapsulating Agent on the Conservation of Resveratrol. Processes, v. 8, 849, 2020.

VINDEROLA, C. G.; MEDICI, M.; PERDIGÓN, G. Relationship between interaction sites in the gut, hydrophobicity, mucosal immunomodulating capacities and cell wall protein profiles in indigenous and exogenous bacteria. Journal of Applied Microbiology, v. 96, p. 230-243, 2004.

ZHAO, D.; SHAH, N. P. Tea and soybean extracts in combination with milk fermentation inhibit growth and enterocyte adherence of selected foodborne pathogens. Food Chemistry, v. 180, p. 306-316, 2015.

ZHOU, Q. et al. Evaluation of the physicochemical stability and digestibility of microencapsulated esterified astaxanthins using in vitro and in vivo models. Food Chemistry, v. 260, p. 73-81, 2018. 


\section{CHAPTER 3 - FORTIFICATION OF YOGURT DRINK WITH MICROCAPSULES LOADED WITH Lacticaseibacillus paracasei BGP-1 AND GUARANÁ SEED EXTRACT ${ }^{1}$}

\footnotetext{
${ }^{1}$ This chapter was published in International Dairy Journal - Copyrights is in Attachment B.

SILVA, M. P. et al. Fortification of yoghurt drink with microcapsules loaded with Lacticaseibacillus paracasei BGP-1 and guaraná seed extract. International Dairy Journal, 125, 105230, 2022.
} 


\title{
4 CHAPTER 3 - FORTIFICATION OF YOGURT DRINK WITH MICROCAPSULES LOADED WITH Lacticaseibacillus paracasei BGP-1 AND GUARANÁ SEED EXTRACT
}

\begin{abstract}
Phenolic compounds and lactic acid bacteria are sensitive to harsh conditions and can change some characteristics of a food matrix, causing the sensation of astringency and post-fermentation, respectively. This study focused on the influence of co-encapsulation of guaraná seed extract (GSE) and Lacticaseibacillus paracasei BGP-1 on the viability of the bacteria and stability of phenolic compounds during storage of microcapsules and after their application in a yogurt drink. Co-encapsulation of the potential probiotic and GSE protected the phenolic compounds, with final retention of around 88\%, and enhanced the viability of the L. paracasei during storage. Concerning the yogurt formulations, microencapsulation prevented post-fermentation and masked the bitter taste of GSE. As a result, the global acceptability of yogurt containing microcapsules was higher than that containing free GSE. In addition, encapsulation and association of GSE allowed for maintenance of L. paracasei counts of about $7 \log \mathrm{CFU} \mathrm{g} \mathrm{g}^{-1}$ in yogurt formulations stored at $7{ }^{\circ} \mathrm{C}$ for up 28 days. Therefore, co-encapsulation represents a valuable tool for the application and protection of functional ingredients in yogurt drinks.
\end{abstract}

Keywords: complex coacervation, probiotic, yogurt, guaraná seed extract, phenolic compounds. 


\subsection{INTRODUCTION}

Association of probiotics and polyphenols is a trend in the functional food market; their beneficial properties boosting our health. Daily intake of probiotics may maintain a healthy gut microbiota, enhancing the digestive and immune systems (HILL et al., 2014). In this way, some lactic acid bacteria are potential probiotics, such as Lacticaseibacillus paracasei BGP-1, which has shown immunomodulatory capacity (MATOS-JR et al., 2019). A benefit of consuming polyphenols is the reduction of the incidence of some degenerative diseases (MANACH et al., 2004). Also, plant polyphenols are considered an emergent prebiotic, as they may be biotransformed by the colonic microbiota (GIBSON et al., 2017).

Among the plants found in the Amazon biome, guaraná is known for its high methylxanthine and polyphenol content (SCHIMPL et al., 2013; YONEKURA et al., 2016). Food and pharmaceutical industries have been using guaraná seeds mainly to extract caffeine, for its stimulating properties. However, the catechins play an essential role in health benefits due to their high antioxidant potential (YONEKURA et al., 2016).

In general, guaraná seed extracts are sold in powder form as a food supplement, which can be applied in beverages and smoothies. However, its taste is considered slightly bitter, causing the sensation of astringency (SCHIMPL et al., 2013). The technology of microencapsulation is a potential option to mask the bitter taste and enable its application in other food matrices.

Furthermore, microencapsulation has also been explored for protecting probiotics during food processing, storage and digestion, as some conditions may cause their death, such as low $\mathrm{pH}$, presence of oxygen and bile salts. In addition, sensory changes in food products with a high water activity, caused by metabolic compounds produced by probiotics, may be prevented by microencapsulation (FAVARO-TRINDADE et al., 2011). Complex coacervation is an encapsulation technique which has demonstrated some advantages for preserving probiotics in simulated gastrointestinal fluids and during storage (MATOS-JR et al., 2019; SILVA et al., 2018). Thus, simultaneous encapsulation of a potential probiotic and guaraná seed extract (GSE) may protect both, as well as be a strategy to enrich yogurt drink by addition of these microcapsules.

Few studies have addressed the effect of co-encapsulation of plant extracts and probiotics, other encapsulation techniques such as emulsification, internal gelation and extrusion have been 
explored (GAUDREAU et al., 2016; SHINDE et al., 2014). However, the influence of applying these microcapsules, to enrich the food matrix, on the final product quality and sensory acceptance has been overlooked.

Yogurt is generally used as a food matrix model for the application of new ingredients, as it is well accepted by consumers. For instance, Georgakouli et al. (2016) supplemented yogurt with encapsulated olive fruit polyphenols, verifying a reduction of blood pressure, LDL cholesterol and body weight in 19 healthy adults. These findings indicate application of microcapsules loaded with probiotic and GSE in yogurt may extend health benefits through the combination of polyphenols and probiotic.

Therefore, the present study aimed to evaluate the effect of simultaneous encapsulation of GSE and L. paracasei by complex coacervation on the viability of the potential probiotic and stability of phenolic compounds during storage, followed by application in yogurt drink (Figure 10). In addition, the yogurt drink formulations were evaluated by a sensory acceptance test and physicochemical characteristics during storage at $7^{\circ} \mathrm{C}$ for 28 days.

Figure 10 - Summary of this study: (1) evaluation of co-encapsulation of probiotic and guaraná seed extract (GSE) by complex coacervation regards viability of probiotic and stability of phenolic compounds and (2) application of microcapsules to enrich yogurt drink formulations, verifying their quality and sensory acceptance.

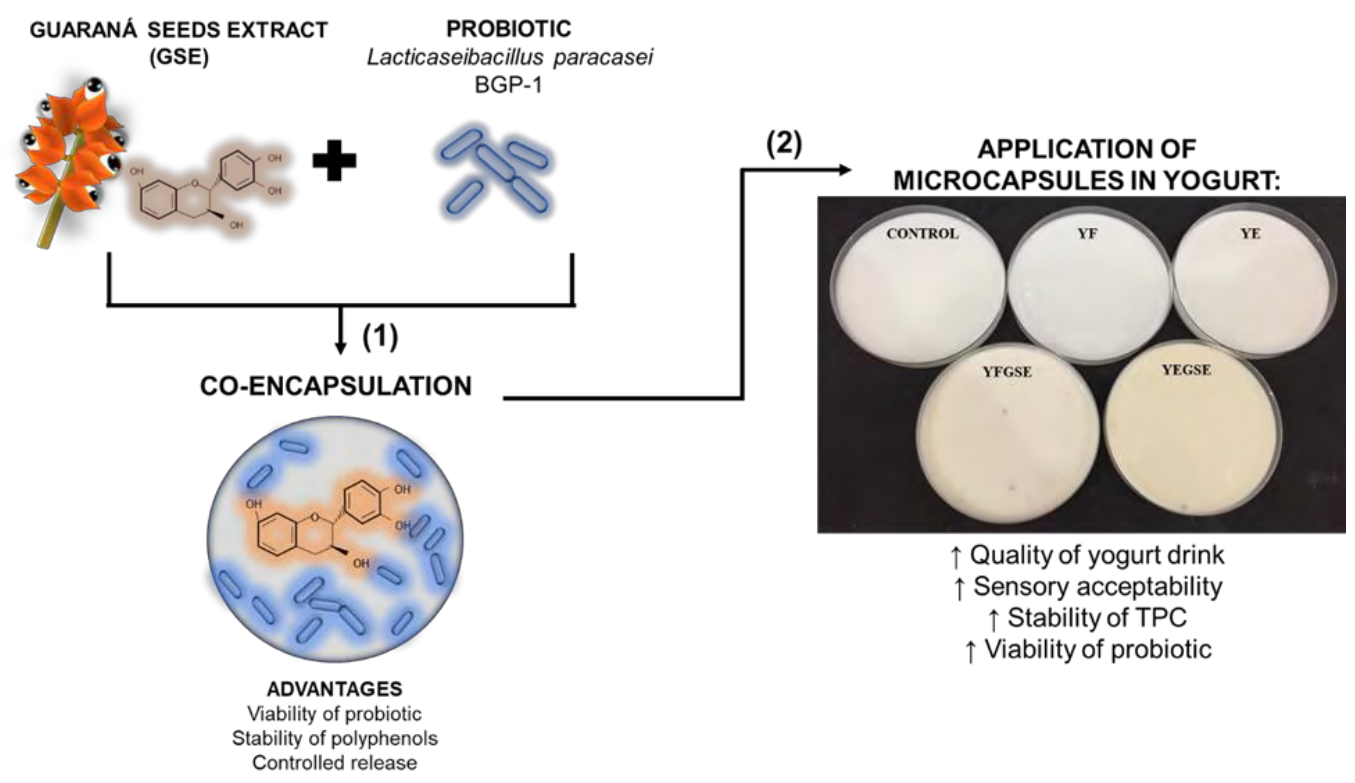

Reference: Own source. 


\subsection{MATERIAL AND METHODS}

\subsubsection{Materials}

A commercial strain of Lacticaseibacillus paracasei BGP-1 was donated by Sacco Brasil (Campinas, Brazil). L. paracasei BGP-1 presents immunomodulatory capacity even after microencapsulation (MATOS-JR et al., 2019). Also, this strain showed good adhesiveness capacity in Caco-2 cells, as reported by the manufacturer.

Guaraná (Paullinia cupana) fruit was kindly donated by the Executive Commission of the Rural Economic Recuperation Plan in Cacao (Taperoá, Brazil). Gelatin (pI 4) and gum Arabic were used as encapsulating materials, purchased respectively from Gelita South America (Mococa, Brazil) and Nexira (São Paulo, Brazil). Natural guaraná flavor for application in yogurt drink was donated by Synergy Flavors (Vinhedo, Brazil).

\subsubsection{Preparation of GSE followed by atomization}

GSE was produced according to the method of Silva et al. (2019) with modifications. The extraction process was performed using mechanical stirring at $60{ }^{\circ} \mathrm{C}$ for $30 \mathrm{~min}$. The proportion of milled, dried guaraná seed and extracting solution was 1:20 (w/w). Hydroalcoholic solutions ranging from $30 \%$ to $60 \%$ (v/v) ethanol were used for extracting phenolic compounds. Around 2.5 L of GSE was produced for each concentration of hydroalcoholic solution studied. In sequence, extracts were atomized in an MSD 1.0 spray dryer (LabMaq, Ribeirão Preto, Brazil) equipped with a $1.2 \mathrm{~mm}$ nozzle, at $150{ }^{\circ} \mathrm{C}$ and feed flow of $10 \mathrm{~mL} \mathrm{~min}^{-1}$.

To evaluate the influence of atomization on total phenolic, catechin, epicatechin, theophylline and caffeine content, extracts were evaluated before and after atomization. Retention of bioactive compounds was calculated by Equation 1:

$$
\text { Retention }(\%)=\frac{\text { Final amount of bioactive compounds }}{\text { Initial amount of bioactive compounds }} \times 100
$$




\subsubsection{Quantification of total phenolic content (TPC)}

TPC was verified by addition of $0.25 \mathrm{~mL}$ of sample to $2 \mathrm{~mL}$ of distilled water and $0.25 \mathrm{~mL}$ of Folin-Ciocalteu reagent (SINGLETON et al., 1999). In sequence, $0.25 \mathrm{~mL}$ of saturated sodium carbonate $\left(\mathrm{Na}_{2} \mathrm{CO}_{3}\right)$ was added to each tube and vortexed, followed by incubation in a water bath at $37{ }^{\circ} \mathrm{C}$ for $30 \mathrm{~min}$ to complete the reaction. Absorbance was measured using a spectrophotometer at $750 \mathrm{~nm}$. TPC was calculated using gallic acid as a reference.

\subsubsection{Quantification of catechin, epicatechin and methylxanthine content}

The catechin and epicatechin content of GSE was analyzed using high-performance liquid chromatography (HPLC) according to Shumow and Bodor (2011), with modifications proposed by Silva et al. (2019). Analyses were performed on an HPLC system (Shimadzu, Kyoto, Japan) with a fluorescence detector (280 nm excitation, $315 \mathrm{~nm}$ emission) and a C18 column (Ascentis, Supelco, $250 \times 4.6 \mathrm{~mm}, 5 \mu \mathrm{m}$ particle, Sigma-Aldrich, St. Louis, MO, USA). The system was maintained at $30{ }^{\circ} \mathrm{C}$, injecting $10 \mu \mathrm{L}$ of samples. The mobile phase was constituted of ultrapure water (Direct-Q, Millipore) acidified with formic acid (Sigma-Aldrich, St. Louis, MO, USA) at pH 3 (A) and acetonitrile (Panreac, Barcelona, Spain) (B) at a flow rate of $1 \mathrm{~mL} \mathrm{~min}^{-1}$. A $40 \mathrm{~min}$ gradient program was used, starting with $5 \% \mathrm{~B}$, increasing to $30 \%$ at $30 \mathrm{~min}, 80 \%$ at $35 \mathrm{~min}$ then a decrease to $5 \%$ at $40 \mathrm{~min}$. Quantification was performed using standard catechin $(2-15 \mu \mathrm{g} \mathrm{mL}-$ ${ }^{1}$ ) and epicatechin $\left(3-30 \mu \mathrm{g} \mathrm{mL}^{-1}\right)$ solutions (Sigma-Aldrich).

To analyze the theophylline and caffeine content of GSE, the methodology described by Klein et al. (2012) was modified. An HPLC system equipped with a diode array detector (272 nm) and a C18 column (Ascentis, Supelco, $250 \times 4.6 \mathrm{~mm}, 5 \mu \mathrm{m}$ particle size) was maintained at $30{ }^{\circ} \mathrm{C}$. The mobile phase was composed of water:methanol:acetonitrile $(75: 20: 5 \mathrm{v} / \mathrm{v})$ at a flow rate of

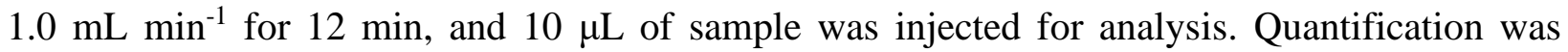
performed using standard caffeine $\left(1-60 \mu \mathrm{g} \mathrm{mL} \mathrm{m}^{-1}\right)$ and theophylline $\left(1-70 \mu \mathrm{g} \mathrm{mL}^{-1}\right)$ solutions (Sigma-Aldrich). Data were collected and processed in LC Solution software, version 1.21 (Shimadzu, Kyoto, Japan). 


\subsubsection{Simultaneous encapsulation of potential probiotic and GSE}

Approximately $50 \mathrm{mg}$ of freeze-dried L. paracasei was added to $10 \mathrm{~mL}$ of MRS broth and incubated for $18 \mathrm{~h}$ at $37{ }^{\circ} \mathrm{C}$. After incubation, the bacterial suspension was added to $100 \mathrm{~mL}$ of MRS broth followed by incubation $\left(37^{\circ} \mathrm{C}, 18 \mathrm{~h}\right)$. Then, cells were separated by centrifugation and washed twice with $2 \%$ sodium citrate solution (SILVA et al., 2018).

Microcapsules were produced as suggested by Souza et al. (2018) with modification. First, approximately $2.5 \mathrm{~g}$ of spray-dried GSE was added to $400 \mathrm{~mL}$ of deionized water and mixed at $6000 \mathrm{rpm}$ for $2 \mathrm{~min}$. Then, $100 \mathrm{~mL}$ of $5 \%$ (w/w) gelatin solution and L. paracasei BGP-1 were added to the mixture and stirred at 12,000 rpm for 2 min using an Ultra Turrax (Ika, Staufen, Germany). Next, $100 \mathrm{~mL}$ of 5\% (w/w) gum Arabic solution was added to the mixture and mixed by magnetic stirring at $400 \mathrm{rpm}$, then the $\mathrm{pH}$ was reduced to $3.8 \mathrm{using}$ citric acid. Control microcapsules were produced without the addition of GSE and the $\mathrm{pH}$ was adjusted to 4 using citric acid.

Sequentially, coacervates were kept in a cold bath and under magnetic stirring until reaching $10^{\circ} \mathrm{C}$. Then, the beaker containing the coacervates was maintained in the fridge overnight for decantation. After that, coacervates were frozen at $-18{ }^{\circ} \mathrm{C}$ for $24 \mathrm{~h}$ and freeze-dried in a lyophilizer (LC 1500, Terroni, São Carlos, Brazil) for $48 \mathrm{~h}$ at a pressure of $1-0.1 \mathrm{kPa}$ with the condenser temperature at $-20^{\circ} \mathrm{C}$ and final temperature at $30^{\circ} \mathrm{C}$.

\subsubsection{Characterization of the microcapsules: average size, viability of encapsulated $L$. paracasei and stability of TPC and polyphenols}

The average diameter of the microcapsules was determined in a Shimadzu SALD-201V laser diffraction particle analyzer (Kyoto, Japan). Samples were dispersed in distilled water, according to the method of Silva et al. (2018).

The stability of encapsulated TPC was evaluated as suggested by Souza et al. (2020) during storage at $7{ }^{\circ} \mathrm{C}$ for 60 days. For the extraction of phenolic compounds, approximately $0.1 \mathrm{~g}$ of microcapsules was dispersed in $2.5 \mathrm{~mL}$ of $\mathrm{NaOH}(0.1 \mathrm{M})$ and $5 \mathrm{~mL}$ of acidified acetone $(0.5 \% \mathrm{v} / \mathrm{v}$ acetic acid). Tubes were kept in a Multi Reax Vortex (Heidolph, Schwabach, Germany) for 30 min 
at room temperature. Then, the samples were centrifuged at $6603 \mathrm{~g}$ at $4{ }^{\circ} \mathrm{C}$ for $5 \mathrm{~min}$. The aqueous phase was collected to quantify for TPC and polyphenols as described in sections 4.2.3 and 4.2.4, respectively.

To determine the viability of encapsulated L. paracasei, $0.1 \mathrm{~g}$ of microcapsules was added to $5 \mathrm{~mL}$ of $2 \%$ sodium citrate solution. Samples were maintained in a Multi Reax Vortex for 10 min to release lactic acid bacteria. Serial dilution was performed followed by inoculation onto MRS agar. The inoculated plates were incubated in anaerobic jars at $37{ }^{\circ} \mathrm{C}$ for 2 days, and the results were expressed as colony forming unit (CFU) per gram of sample.

\subsubsection{Application of microcapsules in yogurt drink}

Yogurt drink was produced at the dairy processing plant at the University of São Paulo (Pirassununga, Brazil). The milk base contained $12 \mathrm{~g}$ of total solids $100 \mathrm{~g}^{-1}$ of milk, which was pasteurized at $63{ }^{\circ} \mathrm{C}$ for $30 \mathrm{~min}$ followed by addition of refined sugar $(10 \% \mathrm{w} / \mathrm{w})$. After cooling to $42{ }^{\circ} \mathrm{C}$, Y472 E starter culture (Sacco, Campinas, Brazil) was added with fermentation for $3 \mathrm{~h}$. The coagulated product was stirred to mechanically disrupt the gel. Yogurt drink was packaged in 1000 $\mathrm{mL}$ plastic bottles, with $10 \mathrm{~kg}$ split into five parts to add the natural guaraná flavor $(0.1 \% \mathrm{w} / \mathrm{w})$, microcapsules or free ingredients following good manufacturing practices. In this way, microcapsules loaded with L. paracasei or microcapsules loaded simultaneously with L. paracasei and GSE were added at $1.5 \% \mathrm{w} / \mathrm{w}$ to the yogurt formulations and mixed by manual shaking. Formulations containing the free L. paracasei $(0.1 \% \mathrm{w} / \mathrm{w})$ and free GSE $(0.21 \% \mathrm{w} / \mathrm{w})$ were previously tested, considering an amount equivalent to that loaded in the microcapsules. Thus, five yogurt formulations were produced: Control - regular yogurt, YF - yogurt containing free $L$. paracasei, YE - yogurt containing encapsulated L. paracasei, YFGSE - yogurt containing free $L$. paracasei and guaraná seed extract (GSE), and YEGSE - yogurt containing encapsulated $L$. paracasei and GSE. 


\subsubsection{Optical microscopy of microcapsules and yogurt drink supplemented with free and co-encapsulated L. paracasei with GSE}

Morphology of microcapsules and yogurt formulations was evaluated by a Leica DM500 microscope equipped with an ICC50 W camera (Leica, Wetzlar, Germany). Micrographs were captured at a magnification of $100 \times$.

\subsubsection{Physicochemical characteristics of yogurt formulations}

The composition of yogurt formulations was determined according to the methods of the AOAC (2005): moisture using drying by desiccation to constant weight, ash by carbonization on a heating plate, proteins by Kjeldahl method, lipids by Soxhlet extraction, crude fiber by enzymatic-gravimetric method and carbohydrates by difference from other fractions.

\subsubsection{Evaluation of functional yogurt drink during storage at $7{ }^{\circ} \mathrm{C}$ for 28 days}

Physical-chemical analyses were performed weekly to characterize the functional yogurt during storage at $7{ }^{\circ} \mathrm{C}$ for 28 days. Titratable acidity of the products was evaluated using $0.1 \mathrm{M}$ $\mathrm{NaOH}$ solution until pH 8.2 (AOAC, 2000). The pH was checked directly using a potentiometer (Marte MB-10, São Paulo, Brazil). Color parameters ( $\mathrm{L}^{*}, \mathrm{a}^{*}$ and $\mathrm{b}^{*}$ ) were evaluated using a colorimeter (HunterLab MiniScan XE, Reston, VA, USA) programmed in the CIELAB system. Thus, the luminance parameter L* (black (0) to white (100)) and the chromatic coordinates a* (green $(-)$ to red $(+))$ and $b^{*}$ (blue $(-)$ to yellow $(+)$ ) were measured.

For stability of TPC, $10 \mathrm{~g}$ of yogurt (control, YFGSE, YEGSE) were added to $10 \mathrm{~mL}$ of $30 \%$ ethanol solution, and tubes were kept in a Multi Reax Vortex for 10 min. Samples were centrifuged (5282 g, $5 \mathrm{~min}$ ) and TPC determined as described in section 4.2.3. Quantification of polyphenols in yogurt formulations was measured on the first and last days of storage following the procedure described in section 4.2.4.

Enumeration of L. paracasei in yogurt was evaluated using MRS agar supplemented with bromophenol blue (KADRI et al., 2018; LEE; LEE, 2008). Then, $10 \mathrm{~g}$ of yogurt was put into a 
plastic bag with $90 \mathrm{~mL}$ of $2 \%$ sodium citrate solution and homogenized using a stomacher (Marconi, Piracicaba, Brazil) for $10 \mathrm{~min}$. Then, samples were serially diluted and plated onto supplemented MRS agar with bromophenol blue. Differentiation of L. paracasei from the starter culture was based on colony morphology; its cells were white and round whereas Streptococcus salivarius subsp. thermophilus and Lactobacillus delbrueckii subsp. bulgaricus (starter culture) showed a grayish elongated shape and tiny white-cream colonies, respectively.

\subsubsection{Sensory acceptance test}

Following the method of Meilgaard et al. (1991), an acceptance test was performed to verify the formulations' sensory attributes of aroma, color, texture, taste and overall acceptability. The five yogurt formulations were evaluated by 117 untrained panelists (77 women and 40 men, aged 18-52), using a 9-point hedonic scale (1 - dislike extremely and 9 - like extremely) at the laboratory of Food Sensory Analysis located at the Department of Food Engineering, University of São Paulo (Pirassununga, Brazil). Each sample was presented individually random order in plastic cups. Also, panelists were asked about their intent to purchase yogurt. This study was approved by the Research Ethics Committee of the Faculdade de Engenharia de Alimentos at the Universidade de São Paulo, process number 13426019.0.0000.5422.

\subsubsection{Statistical analysis}

All experiments were performed in triplicate. Data were evaluated by analysis of variance (ANOVA) and Tukey's test at the significance level of 5\%, using the SAS statistical package (version 9.2, SAS Institute Inc., Cary, NC, USA). 


\subsection{RESULTS AND DISCUSSION}

\subsubsection{Evaluation of spray-dried GSE}

The chemical profile of phenolic compounds found in GSE has been investigated before, with high levels of catechins and TPC of $438 \mathrm{mg}$ of gallic acid equivalents (GAE) $\mathrm{g}^{-1}$ of powder (SILVA et al., 2017). However, the present study evaluated the effect of extraction and atomization by spray dryer (without carrier) on the content and retention of bioactive compounds in powdered GSE.

Several conditions were tested to achieve maximum extraction of phenolic compounds from guaraná seeds. In preliminary tests, hydroalcoholic solutions containing $30 \%$ to $60 \%$ ethanol were efficient in extracting total phenolic compounds (SILVA et al., 2019). However, use of hydroalcoholic extract can cause death of L. paracasei due to the ethanol. Thus, the hydroalcoholic extract was atomized to remove the ethanol and water. In addition, atomization was performed without adding carrier to the extract, to avoid any interference in the possible synergistic influence between the GSE and L. paracasei. Characterization of total phenolic, catechin, epicatechin, theophylline and caffeine content and retention values after atomization can be seen in Table 6 .

The amount of GSE powder obtained was approximately $18 \mathrm{~g}$ for each treatment, with a final moisture content of $3.9 \pm 0.2 \%$ and water activity of $0.24 \pm 0.05$. Using different hydroalcoholic solutions to extract bioactive compounds did not affect the methylxanthine and catechin content of the GSE powders. However, TPC in the powders was influenced by the extraction solution, ranging from 362 to $401 \mathrm{mg} \mathrm{GAE} \mathrm{g}^{-1}$. The highest TPC was recovered using a hydroalcoholic solution of $30 \%$ ethanol. One advantage of applying the hydroalcoholic solution containing the lowest concentration of ethanol $(30 \%)$ is the safety and non-toxicity of water to extract bioactive compounds. For this reason, this extraction solution was selected for recovery of phenolic compounds from guaraná seeds, as some phenolic compounds can promote survival of $L$. paracasei through their antioxidant capacity.

Another study verified the catechin and epicatechin content in commercial guaraná powder as around 30 and $20 \mathrm{mg} \mathrm{g}^{-1}$, respectively (YONEKURA et al., 2016). Possibly, that product was 
atomized using carrier, which could explain the lower values compared with the present study that found 133 and $362 \mathrm{mg} \mathrm{g}^{-1}$ of catechin and epicatechin in GSE powder, respectively. However, using this powder without a carrier can reduce the stability of phenolic compounds; thus, microencapsulation is required to protect them.

Table 6 - Bioactive compounds content after atomization of guaraná seed extract (GSE) and retention, expressed as mg g-1 on a dry basis and percentage (\%), respectively.

\begin{tabular}{|c|c|c|c|c|c|}
\hline $\begin{array}{l}\text { Extracting } \\
\text { solution }\end{array}$ & $\begin{array}{l}\text { Total Phenolic } \\
\text { Content (TPC) }\end{array}$ & Catechin & Epicatechin & Theophylline & Caffeine \\
\hline \multicolumn{6}{|c|}{ Content $\left(\mathrm{mg} \mathrm{g}^{-1}\right)$} \\
\hline $30 \%$ ethanol & $401.92 \pm 0.11^{\mathrm{A}}$ & $132.99 \pm 6.10^{\mathrm{A}}$ & $362.24 \pm 19.00^{\mathrm{A}}$ & $18.26 \pm 0.17^{\mathrm{A}}$ & $144.46 \pm 0.26^{\mathrm{A}}$ \\
\hline $40 \%$ ethanol & $374.23 \pm 8.82^{\mathrm{B}}$ & $115.39 \pm 0.16^{\mathrm{A}}$ & $320.22 \pm 0.58^{\mathrm{A}}$ & $17.60 \pm 1.29^{\mathrm{A}}$ & $132.45 \pm 4.65^{\mathrm{A}}$ \\
\hline $50 \%$ ethanol & $375.93 \pm 3.79^{\mathrm{B}}$ & $138.10 \pm 8.14^{\mathrm{A}}$ & $378.15 \pm 15.53^{\mathrm{A}}$ & $18.40 \pm 0.16^{\mathrm{A}}$ & $145.94 \pm 5.62^{\mathrm{A}}$ \\
\hline $60 \%$ ethanol & $362.44 \pm 2.90^{\mathrm{B}}$ & $139.10 \pm 6.47^{\mathrm{A}}$ & $380.17 \pm 18.30^{\mathrm{A}}$ & $16.63 \pm 2.15^{\mathrm{A}}$ & $140.00 \pm 13.29^{\mathrm{A}}$ \\
\hline \multicolumn{6}{|c|}{ Retention (\%) } \\
\hline $30 \%$ ethanol & $80.45 \pm 2.66^{\mathrm{C}}$ & $83.72 \pm 11.21^{\mathrm{A}}$ & $89.35 \pm 12.90^{\mathrm{A}}$ & $78.34 \pm 7.46^{\mathrm{A}}$ & $75.66 \pm 6.43^{\mathrm{A}}$ \\
\hline $40 \%$ ethanol & $82.34 \pm 1.54^{\mathrm{BC}}$ & $79.85 \pm 0.91^{\mathrm{A}}$ & $85.96 \pm 0.93^{\mathrm{A}}$ & $88.54 \pm 3.73^{\mathrm{A}}$ & $87.10 \pm 4.06^{\mathrm{A}}$ \\
\hline $50 \%$ ethanol & $87.43 \pm 0.67^{\mathrm{AB}}$ & $100.33 \pm 12.62^{\mathrm{A}}$ & $103.31 \pm 11.35^{\mathrm{A}}$ & $94.21 \pm 3.92^{\mathrm{A}}$ & $95.99 \pm 2.79^{\mathrm{A}}$ \\
\hline $60 \%$ ethanol & $90.35 \pm 0.06^{\mathrm{A}}$ & $94.93 \pm 8.07^{\mathrm{A}}$ & $99.15 \pm 9.08^{\mathrm{A}}$ & $94.57 \pm 13.73^{\mathrm{A}}$ & $95.68 \pm 15.43^{\mathrm{A}}$ \\
\hline \multicolumn{6}{|c|}{ Values with the same upper-case letter in a column are not statistically different (p>0.05). } \\
\hline \multicolumn{6}{|c|}{$\begin{array}{l}\text { Concerning retention of bioactive compounds, the atomization process affected } t \\
\text { for phenolic compounds; they varied from } 80 \% \text { to } 90 \% \text {. Although the atomized pro } \\
\text { ning } 60 \% \text { ethanol had the least change in TPC achieving a retention of } 90 \% \text {, most o }\end{array}$} \\
\hline
\end{tabular}


Similar results were obtained by Klein et al. (2015) who microencapsulated GSE by spray drying at $190{ }^{\circ} \mathrm{C}$ using gum Arabic and maltodextrin as carriers. Catechin and epicatechin retentions were $81.53 \%$ and $82.10 \%$, respectively.

All samples had a theophylline content of approximately $17 \mathrm{mg} \mathrm{g}^{-1}$, it being the bioactive compound found at the lowest concentration in the GSE powder. This result is in accordance with

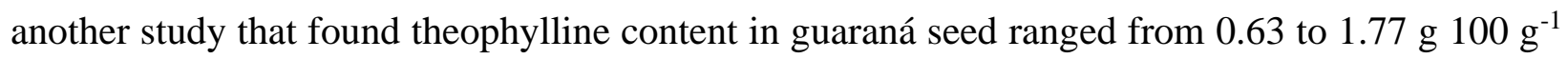
of extract, obtained by maceration using hot hydroalcoholic solutions (SANTANA; MACEDO, 2019).

Theobromine was not detected in the GSE before or after atomization. According to Suzuki and Waller (1984), theobromine is a precursor to caffeine and can also be a degradation product of this alkaloid. Therefore, theobromine was probably converted to caffeine during the ripening of guaraná seeds.

The caffeine content in the GSE powder varied from 132 to $146 \mathrm{mg} \mathrm{g}^{-1}$. These values are in accordance with results of Majhenic et al. (2007) who evaluated commercial powdered GSE using different solvents. In general, caffeine displays thermal stability, which may be confirmed by the high retention values of around $75 \%$ even after atomization at $150{ }^{\circ} \mathrm{C}$.

Thus, bioactive compounds from GSE may have simultaneous stimulant and antioxidant effects due to the presence of caffeine and catechin, respectively. These properties are attractive for developing functional foods; thus, GSE may be a potential food ingredient. However, the coencapsulation of L. paracasei and phenolic-rich GSE as a joint solution for masking the bitter taste of this extract and preventing post-fermentation of yogurt by the addition of L. paracasei.

\subsubsection{Characterization of microcapsules}

4.3.2.1 Volume weight mean diameter $\left(D_{4,3}\right)$, stability of TPC and viability of $L$. paracasei

Particle size is a critical parameter for application of microcapsules in a food matrix. Another study has indicated that a particle size below $100 \mu \mathrm{m}$ might prevent any unpleasant change 
in sensory attributes (COMUNIAN et al., 2017). However, other aspects based on quantity of microcapsules to be applied and texture properties of the food matrix should be considered.

Mean diameter of atomized GSE was smaller, $12.8 \mu \mathrm{m}$, while mean microcapsule size ranged between 128 and $145 \mu \mathrm{m}$, regardless of whether microcapsules were loaded only with $L$. paracasei (control) or with GSE and L. paracasei ( $\mathrm{p}>0.05$ ). This result is in accordance with that of Souza et al. (2018) who verified mean diameter of atomized cinnamon extract as $7.6 \mu \mathrm{m}$, and a diameter of microcapsules obtained by complex coacervation using gelatin and gum Arabic was $121 \mu \mathrm{m}$.

Our results are in accordance with another study that encapsulated L. paracasei by complex coacervation using gelatin type-A and gum Arabic, which showed a mean diameter of $150 \mu \mathrm{m}$ by laser diffraction particle sizing (ZHAO et al., 2020). On the other hand, a smaller diameter of 80 $\mu \mathrm{m}$ was reported by Silva et al. (2018), who developed lipid particles produced by electrostatic interaction of gelatin and gum Arabic. The combination of vegetable fat in the production of microcapsules by complex coacervation could be an alternative to reduce mean diameter. However, solid lipid particles applied to a yogurt drink could precipitate, depreciating the final product's appearance. Furthermore, storage of yogurt drink for 28 days, even at low temperatures, could favor oxidation of solid lipid microparticles due to the high-water activity.

Concerning the storage conditions, freeze-dried microcapsules were kept at $7^{\circ} \mathrm{C}$, to verify their potential application in food matrices stored in the same temperature range. In this way, if the viability of encapsulated L. paracasei could be maintained and GSE were stable, application of microcapsules in yogurt might be promising.

Viability of encapsulated L. paracasei simultaneously loaded with GSE, counts varied from 9.0 to $8.3 \log \mathrm{CFU} \mathrm{g}^{-1}$ at the beginning and after 60 days of storage, respectively (Figure 11). On the other hand, the viability of L. paracasei loaded in control microcapsules (without GSE) was about $8.7 \log \mathrm{CFU} \mathrm{g}{ }^{-1}$ at the beginning of storage and around $5.2 \log \mathrm{CFU} \mathrm{g}{ }^{-1}$ after 60 days at 7 ${ }^{\circ} \mathrm{C}$. Therefore, the L. paracasei loaded in control microcapsules was reduced by $3.5 \log \mathrm{CFU} \mathrm{g}{ }^{-1}$ during storage, while the viability of L. paracasei loaded with GSE did not change significantly. Thus, GSE positively affected viability of $L$. paracasei loaded in microcapsules. Furthermore, its composition including a high level of catechin, a well-known antioxidant, could have reduced 
oxidative stress, maintaining L. paracasei viability for longer. Another study reported that catechins can prevent adverse effects of exposure to oxygen during the multiplication and storage of Lactobacillus helveticus (GAUDREAU et al., 2013). Thus, it is important to indicate that viability of encapsulated L. paracasei depends on several factors, including characteristics of the strain and the kind of phenolic compound associated with the microcapsule since this synergistic interaction is probably related to its antioxidant activity.

Our results are in accordance with those of Chaikham (2015), who evaluated the influence of Thai herb extracts on the viability of probiotic by co-encapsulation. Cashew flower extract improved the survival of encapsulated probiotic compared with control alginate beads (CHAIKHAM, 2015). On the other hand, Chávarri et al. (2010) verified that simultaneous loading of chitosan-coated alginate beads with probiotic and quercetin did not extend the viability of the probiotic. Furthermore, these authors highlighted that the freeze-drying process could cause osmotic stress, and quercetin did not protect the cells.

Figure 11 shows that the TPC loaded in microcapsules varied between 56 and $50 \mathrm{mg}$ GAE $\mathrm{g}^{-1}$ during storage, displaying around $88 \%$ retention of TPC. Besides that, the catechin content in microcapsules was stable after storage, while the epicatechin content presented a significant reduction of $8.3 \mathrm{mg} \mathrm{g}^{-1}$. Reduction of epicatechin content may be related to the GSE remaining on the surface of microcapsules exposed to the environment.

Silva et al. (2019) encapsulated GSE by spray chilling using vegetable fat as a carrier, and obtained lower levels of bioactive compounds in microparticles as $29 \mathrm{mg} \mathrm{GAE} \mathrm{g}^{-1}, 9 \mathrm{mg}$ catechin $\mathrm{g}^{-1}$ and $17 \mathrm{mg}$ epicatechin $\mathrm{g}^{-1}$. In this way, complex coacervation proved to be efficient in loading more GSE per gram of microcapsules.

In addition, Souza et al. (2020) verified that around 60\% of TPC in microcapsules loaded with cinnamon extract using gelatin and gum Arabic was retained after 120 days of storage at 25 ${ }^{\circ} \mathrm{C}$. Although storage conditions were different, application of polymers by complex coacervation effectively protected TPC from plant extracts. 
Figure 11 - Stability of freeze-dried microcapsules loaded with L. paracasei BGP-1 (LP) and guaraná seed extract (GSE), regarding total phenolic content (TPC) (A), epicatechin (B) and catechin (C) contents stored at $7{ }^{\circ} \mathrm{C}$ for 60 days. Viability of LP loaded in control microcapsules (without GSE) and LP simultaneously loaded with GSE in microcapsules (D) during the storage. Bars with the same lower letters of the same formulation are not statistically different. Bars with the same upper letters in the same time interval are not statistically different $(\mathrm{p}>0.05)$.
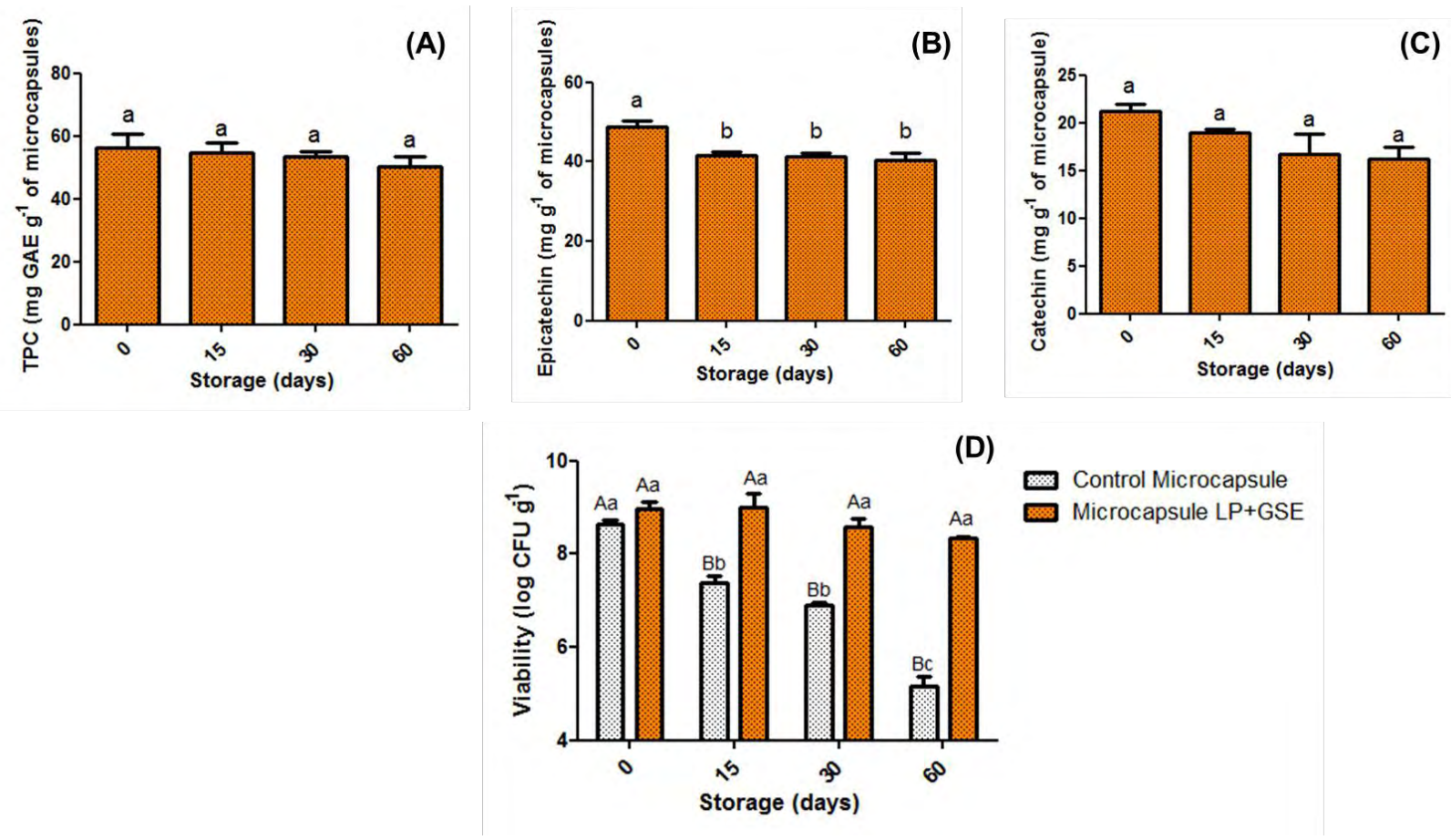

Reference: Own source.

\subsubsection{Characterization of yogurt formulations}

\subsubsection{Optical microscopy of yogurt drink formulations supplemented with microcapsules}

Morphology of microcapsules and yogurt formulations containing free or microencapsulated L. paracasei and GSE are exhibited in Figure 12. In this study, both types of microcapsule after rehydration had a spherical shape and varied in diameter. In addition, microcapsules loaded with GSE and L. paracasei were brownish, which is the typical color of some phenolic compounds.

Application of free and encapsulated L. paracasei and phenolic compounds from GSE in yogurt drink occurred in the final stage of yogurt production. There are some justifications for 
applying microcapsules and free ingredients after the stirring of yogurt: (1) variation in $\mathrm{pH}$ during fermentation could increase the expulsion of core materials from the microcapsules; (2) the mechanical stirring could probably disrupt the microcapsules. For this reason, evaluation of the yogurt drink by optical microscopy was necessary to verify if microcapsules were intact after application.

Simultaneous addition of free L. paracasei and GSE (YFGSE) resulted in brownish aggregation of the powder in the yogurt drink with a particle size of $0.23 \mathrm{~mm}$ under acidic conditions. In addition, images shown in Figure 10 display this aspect of dark spots in the yogurt drink, evidencing that GSE powder did not dissolve in the yogurt drink. On the other hand, the microcapsules loaded with L. paracasei and GSE remained intact in yogurt drink, improving the homogenization of GSE in the drink and enhancing this product's final appearance, as can be correlated with images exhibited in Figure 12.

Likewise, Comunian et al. (2017) reported that simultaneous encapsulation of echium oil, phytosterol and sinapic acid by complex coacervation improved the dispersion of these bioactive compounds in yogurt. Co-encapsulation is advantageous due to the loading of multiple compounds, producing a standardized product by applying microcapsules.

\subsubsection{Physicochemical characteristics of yogurt drink formulations: proximate composition, $\mathrm{pH}$, titratable acidity (TA), color and TPC}

Yogurt drink was selected as a model system for application of microcapsules, considering its high acceptability and convenience. Table 7 shows the proximate composition of the drink, indicating that moisture, ash and carbohydrates did not differ significantly among formulations. Regarding the protein content of the formulations, those containing microcapsules simultaneously loaded with L. paracasei and GSE showed the highest content, probably due to the presence of gelatin and L. paracasei cells. Although the L. paracasei cells and microcapsules did not contain lipids, formulations YF and YE contained 2.9\% lipids, while the control formulation contained $1.9 \%$. There was a slight variation of lipid content that was unexpected since the major composition of lactic acid bacteria and microcapsules is proteins and carbohydrates. Crude fiber content varied among formulations from $0.76 \%$ to $0.63 \%$, showing that these yogurt drinks are not a source of fiber, which should be supplemented in the diet. 
Figure 12 - Micrographs of microcapsules and yogurts formulations. In this Figure: (A) rehydrated microcapsules loaded with L. paracasei BGP-1 (control microcapsule), (B) rehydrated microcapsules simultaneously loaded with L. paracasei BGP-1 and guaraná seed extract (GSE) (microcapsule LP+GSE), (C) yogurt drink supplemented with encapsulated L. paracasei BGP-1 - YE, (D) yogurt drink simultaneously supplemented with free L. paracasei BGP-1 and GSE - YFGSE, and (E) yogurt drink supplemented with encapsulated $L$. paracasei BGP-1 simultaneously with GSE - YEGSE.

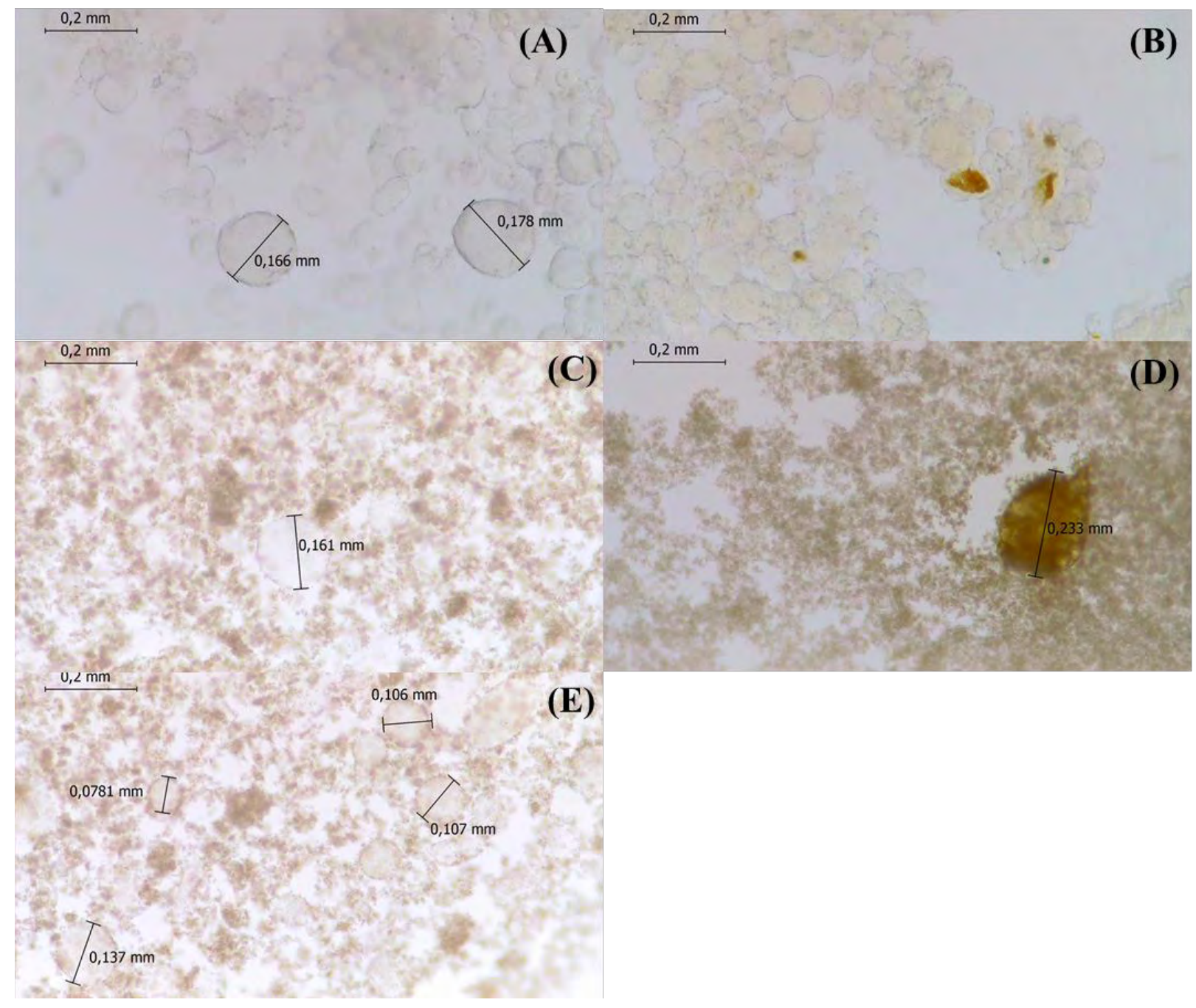

Reference: Own source. 
Table 7 - Proximate composition of functional yogurt drink formulations.

\begin{tabular}{cccccc}
\hline Parameters & Control & YF & YE & YFGSE & YEGSE \\
\hline Moisture (\%) & $81.10 \pm 0.71^{\mathrm{a}}$ & $76.05 \pm 3.04^{\mathrm{a}}$ & $75.70 \pm 1.56^{\mathrm{a}}$ & $77.60 \pm 2.26^{\mathrm{a}}$ & $74.10 \pm 2.55^{\mathrm{a}}$ \\
Ash (\%) & $0.63 \pm 0.04^{\mathrm{a}}$ & $0.75 \pm 0.04^{\mathrm{a}}$ & $0.76 \pm 0.05^{\mathrm{a}}$ & $0.73 \pm 0.05^{\mathrm{a}}$ & $0.76 \pm 0.08^{\mathrm{a}}$ \\
Protein (\%) & $2.49 \pm 0.14^{\mathrm{b}}$ & $3.45 \pm 0.45^{\mathrm{ab}}$ & $3.74 \pm 0.28^{\mathrm{ab}}$ & $3.32 \pm 0.36^{\mathrm{ab}}$ & $3.97 \pm 0.38^{\mathrm{a}}$ \\
Lipids (\%) & $1.87 \pm 0.06^{\mathrm{b}}$ & $2.86 \pm 0.15^{\mathrm{a}}$ & $2.87 \pm 0.14^{\mathrm{a}}$ & $2.52 \pm 0.26^{\mathrm{ab}}$ & $2.60 \pm 0.27^{\mathrm{ab}}$ \\
Crude fiber (\%) & $0.63 \pm 0.04^{\mathrm{c}}$ & $0.75 \pm 0.04^{\mathrm{b}}$ & $0.76 \pm 0.05^{\mathrm{b}}$ & $0.73 \pm 0.05^{\mathrm{bc}}$ & $0.76 \pm 0.08^{\mathrm{a}}$ \\
& & & & \\
Carbohydrates & $14.42 \pm 0.47^{\mathrm{a}}$ & $17.28 \pm 2.52^{\mathrm{a}}$ & $17.44 \pm 1.16^{\mathrm{a}}$ & $16.30 \pm 1.65^{\mathrm{a}}$ & $18.59 \pm 1.82^{\mathrm{a}}$ \\
$(\%)$ & & & & &
\end{tabular}

In this table, Control - regular yogurt, YF - yogurt containing free L. paracasei, YE - yogurt containing encapsulated L. paracasei, YFGSE - yogurt containing free L. paracasei and guaraná seed extract (GSE), and YEGSE - yogurt containing encapsulated L. paracasei and GSE. Values with the same lower-case letter in a row are not statistically different ( $p>0.05)$. Reference: Own source.

Figure 13 displays the characterization of yogurt formulations up to 28 days of storage at $7{ }^{\circ} \mathrm{C}$. Yogurt formulations containing free L. paracasei (YF) and free L. paracasei and GSE (YFGSE) showed a significant reduction of $\mathrm{pH}$ during storage, as well as an increase in TA. These results indicate that free $L$. paracasei increases the acidification of yogurt drink during storage because it remains metabolically active. On the other hand, in the control yogurt and formulations containing microcapsules, the $\mathrm{pH}$ and $\mathrm{TA}$ were maintained up to 28 days of storage, demonstrating that microencapsulation prevented post-fermentation of yogurt drink.

These results are in accordance with those of Shoji et al. (2013), who microencapsulated L. acidophilus by complex coacervation and applied the microcapsules in buffalo milk yogurt. The final $\mathrm{pH}$ and TA of their formulations ranged from 4.01 to 4.20 and 0.96 to 1.45 , respectively. In this way, microencapsulation is an important tool for maintaining the quality and sensory characteristics of food supplemented with potential probiotics and other bioactive compounds. 
In addition, consumers are influenced by a product's attractiveness, thus color is one of the most relevant appearance aspects. Application of plant extracts in yogurt may change the color of the conventionally white product, probably affecting product acceptability. Concerning the luminosity of formulations, only control yogurt and YF did not differ significantly up to 28 days (Figure 13). Thus, the application of microcapsules or free extract changed the luminosity of the yogurt drink. In addition, formulations containing free or encapsulated GSE presented the highest values for the color parameter $b^{*}$ due to the yellowish color of GSE. The color parameter $\mathrm{a}^{*}$ was maintained in YE and YFGSE formulations for up to 28 days.

Similarly, another study verified that the application of apple pomace in stirred yogurt decreased luminosity and increased the color parameters $a^{*}$ and $b^{*}$ (WANG et al., 2020). Thus, despite changes in the color parameters during the storage of yogurt drink, addition of phenolics from GSE can provide health benefits due to their antioxidant potential, which can be a desirable claim.

Stability of TPC in yogurt drink containing free or encapsulated GSE was evaluated during storage, as shown in Figure 13. Application of free and encapsulated GSE, yogurt formulations presented TPC of $200 \mu \mathrm{g} \mathrm{GAE} \mathrm{g}^{-1}$. However, TPC in yogurt formulations increased significantly up to 21 days. After 28 days of storage, formulations containing encapsulated GSE showed a higher TPC than those containing free GSE, the mean values being $304 \mu \mathrm{g}$ and $265 \mu \mathrm{g} \mathrm{GAE} \mathrm{g}^{-1}$ of yogurt, respectively. Based on these results, most of the L. paracasei and TPC were protected by the combination of polymers during storage of yogurt, which could slow down post-fermentation and hence degradation of TPC.

However, there are some limitations to the Folin-Ciocalteu method for quantification of TPC because other compounds may react and over-estimate the results (AINSWORTH; GILLESPIE, 2007). Besides that, enzymatic activity during the storage of yogurt drink could increase TPC since even the regular yogurt (control) showed this rise.

Evaluation of the catechin and epicatechin content in the yogurt drink was performed on the first and last days of storage. Approximately $46.3 \%$ and $42.7 \%$, respectively, of catechin and epicatechin were retained in yogurt containing free GSE. For yogurt containing encapsulated GSE, these values were higher, $57.6 \%$ and $55.3 \%$, respectively. Correlating the retention of polyphenols 
in microcapsules stored at $7{ }^{\circ} \mathrm{C}$ for 60 days (Figure 11), values were $78 \%$ for catechin and $84 \%$ for epicatechin. Thus, the acidic matrix or even the biotransformation of polyphenols induced a reduction of the catechin and epicatechin content in the yogurt drink. However, only the evaluation of metabolites can confirm this.

Figure 13 - Evaluation of $\mathrm{pH}(\mathrm{A})$, titratable acidity (TA) (B), color parameters L* (C), a* (D), b* (E), total phenolic content (TPC) (F) and viability of free and encapsulated L. paracasei BGP-1 (G) in yogurt drink during the storage at $7{ }^{\circ} \mathrm{C}$ for 28 day. In this Figure: black bar is the control formulation (regular yogurt), white bar is the yogurt containing free probiotic (YF), white bar filled with dots is the yogurt containing encapsulated probiotic (YE), orange bar is the yogurt containing free probiotic and GSE (YFGSE) and orange bar filled with dots is the yogurt containing co-encapsulated probiotic and GSE (YEGSE). Bars with the same upper letters in the same time interval are not statistically different. Bars with the same lower letters of the same formulation are not statistically different ( $p>0.05)$.
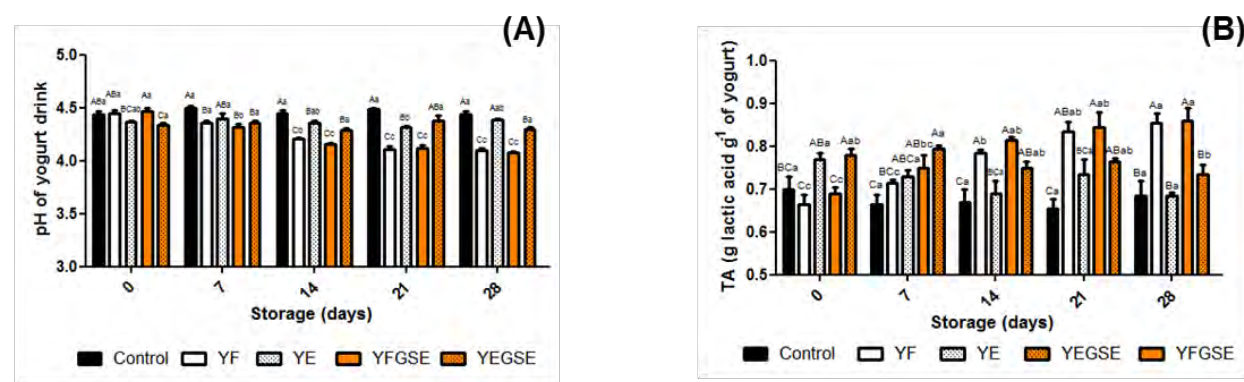

(B)

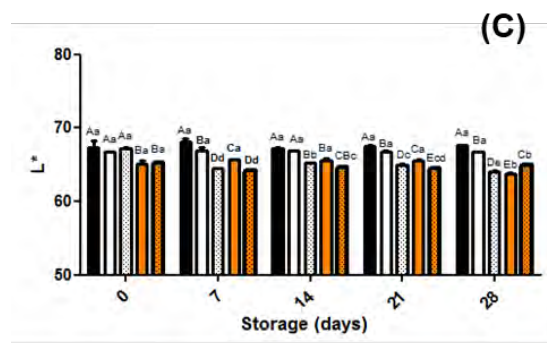

(C)

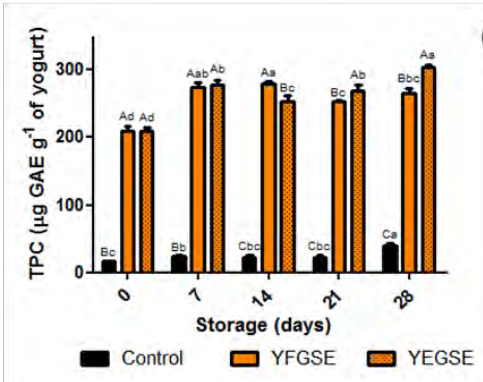

(D)

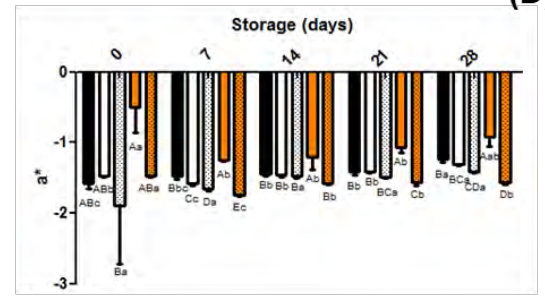

(E)

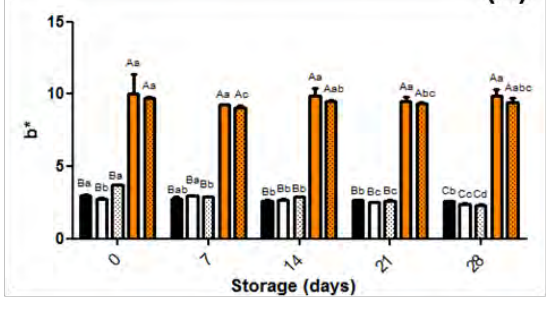

(G)

(F)

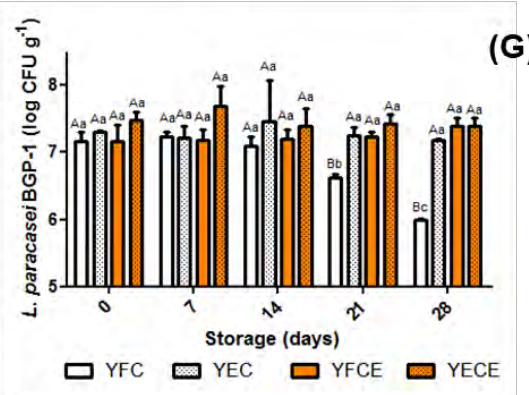

Reference: Own source.

Another study observed the increase of TPC in sugarcane juice supplemented with probiotic and cinnamon extract during storage, correlating this with the metabolization of polyphenols by probiotics (HOLKEM et al., 2020). For this reason, HPLC analysis could be an 
option to verify if phenolic compounds are biotransformed by lactic acid bacteria producing metabolites during storage of the product, thereby increasing TPC.

\subsubsection{Viability of free and encapsulated L. paracasei in yogurt drink during storage}

Figure $13 \mathrm{G}$ shows the viability of L. paracasei in yogurt drink during storage at $7{ }^{\circ} \mathrm{C}$ for 28 days. Initial counts of free and encapsulated $L$. paracase $i$ incorporated into yogurt drink were approximately $7 \log$ CFU g ${ }^{-1}$, which is the recommended intake to get the beneficial effects of probiotics. However, at the end of storage, yogurt containing free L. paracasei displayed the lowest viability, around $6 \log \mathrm{CFU} \mathrm{g} \mathrm{g}^{-1}$, compared with other formulations that presented counts above 7 $\log$ CFU g ${ }^{-1}$. Therefore, encapsulation or the combination with GSE increased viability of the potential probiotic in yogurt drink.

As mentioned previously, antioxidant capacity of catechin may reduce oxidative stress, preventing the death of $L$. paracasei. For this reason, even the count of the free L. paracase $i$ population added to the yogurt formulation containing GSE (YFGSE) was maintained over 28 days.

Similar results were found by Kadri et al. (2018), who verified viability of free and encapsulated $L$. paracasei added to yogurt. After 28 days of storage, counts were approximately

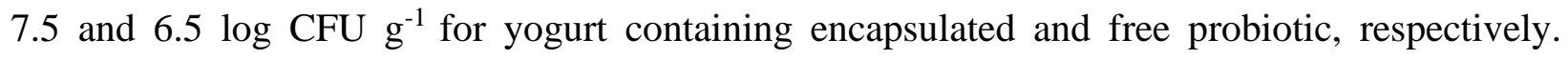
Another study verified that co-encapsulation of probiotic and green tea improved viability of probiotic in fruit juice and yogurt (CHAIKHAM, 2015). In this study, encapsulation increased viability of the L. paracasei added to yogurt, as well as maintaining the quality of the product.

\subsubsection{Sensory acceptance}

Table 8 displays the means of the sensory attributes assigned to the yogurt formulations by untrained panelists. Among the samples, YFGSE had the lowest score for all sensory attributes, demonstrating the importance of microencapsulation of GSE in yogurt drink. Addition of free GSE was performed by manual shaking and most of the GSE particles were suspended in the yogurt. In this way, untrained panelists observed spray-dried GSE particles in the YFGSE formulation, which 
probably affected their opinion about the product. On the other hand, yogurt containing microcapsules loaded with GSE, YEGSE, showed global acceptability of around 7.5, as good as that of the other formulations. In addition, GSE was entrapped in microcapsules since the untrained panelists did not sense its bitterness when in the mouth.

Table 8 - Sensory attributes of functional yogurt drinks using a 9-point hedonic scale $(1=$ dislike extremely and $9=$ like extremely).

\begin{tabular}{cccccc}
\hline Formulations & Aroma & Color & Texture & Taste & $\begin{array}{c}\text { Global } \\
\text { Acceptability }\end{array}$ \\
& & & & \\
\hline Control & $7.48 \pm 1.48^{\mathrm{A}}$ & $7.68 \pm 1.47^{\mathrm{AB}}$ & $7.70 \pm 1.33^{\mathrm{A}}$ & $7.94 \pm 1.25^{\mathrm{A}}$ & $7.88 \pm 1.07^{\mathrm{A}}$ \\
YF & $7.56 \pm 1.40^{\mathrm{A}}$ & $7.75 \pm 1.29^{\mathrm{A}}$ & $7.45 \pm 1.44^{\mathrm{AB}}$ & $7.79 \pm 1.19^{\mathrm{A}}$ & $7.79 \pm 1.03^{\mathrm{A}}$ \\
YE & $7.45 \pm 1.37^{\mathrm{A}}$ & $7.60 \pm 1.50^{\mathrm{AB}}$ & $7.38 \pm 1.57^{\mathrm{AB}}$ & $7.86 \pm 1.17^{\mathrm{A}}$ & $7.77 \pm 1.09^{\mathrm{A}}$ \\
YFGSE & $6.90 \pm 1.64^{\mathrm{B}}$ & $6.19 \pm 1.98^{\mathrm{C}}$ & $6.95 \pm 1.67^{\mathrm{B}}$ & $6.98 \pm 1.79^{\mathrm{B}}$ & $6.81 \pm 1.55^{\mathrm{B}}$ \\
YEGSE & $7.50 \pm 1.51^{\mathrm{A}}$ & $7.13 \pm 1.73^{\mathrm{B}}$ & $7.65 \pm 1.49^{\mathrm{A}}$ & $7.56 \pm 1.45^{\mathrm{A}}$ & $7.56 \pm 1.34^{\mathrm{A}}$
\end{tabular}

In this table, Control - regular yogurt, YF - yogurt containing free L. paracasei, YE - yogurt containing encapsulated L. paracasei, YFGSE - yogurt containing free L. paracasei and guaraná seed extract (GSE), and YEGSE - yogurt containing encapsulated L. paracasei and GSE. Values with the same upper-case letter in a column are not statistically different ( $p>0.05)$. Reference: Own source.

These findings are in accordance with those of Souza et al. (2020) who investigated the application of free and encapsulated cinnamon extract in ice cream. Panelists preferred the ice cream containing microcapsules, considering that the encapsulating materials entrapped the cinnamon extract, masking its bitter taste.

Concerning the color of yogurt formulations, control, YF and YE formulations had the highest scores. As expected, the traditional white color of yogurt was preferred by the panelists. Besides that, the application of GSE was not intended to color the product but rather to enhance the bioactive compounds in this food matrix. However, the color attribute score for YEGSE did not differ significantly from that of control and YE formulations, differently from YFGSE that presented the lowest color attribute score. Although the addition of microcapsules loaded with GSE affected the final color of the product (Figure 10), the aroma, taste and global acceptability 
attributes indicated that co-encapsulation is a useful tool for application of plant extract to yogurt drinks.

The texture attribute score of yogurt formulations containing microcapsules did not differ from that of the control. Another study demonstrated that application of encapsulated probiotic in yogurt affected the texture attribute, but the overall acceptability was not influenced by addition of free or encapsulated probiotic (KAILASAPATHY, 2006).

Regarding purchase intention, $76 \%, 72 \%, 70 \%, 45 \%$ and $70 \%$ of panelists would buy the control, YF, YE, YFGSE and YEGSE formulations, respectively. The reason for the low intention purchase for YFGSE was the astringency and appearance of this formulation due to the application of free GSE. However, the microencapsulation was successful in masking the astringency of GSE and improving the appearance of the formulation.

\subsection{CONCLUSIONS}

Even after atomization, the GSE obtained using 30\% ethanol solution retained most of its methylxanthines and polyphenols. In addition, simultaneous encapsulation of L. paracasei and GSE provided greater viability of the probiotic, and TPC and catechin content was maintained during storage. Application of microcapsules loaded with L. paracasei enhanced several aspects of the yogurt, such as the quality parameters (pH, TA) and viability of the probiotic. Besides that, addition of microcapsules simultaneously loaded with $L$. paracasei and GSE improved the stability of TPC and overall acceptability of the YEGSE formulation. Therefore, co-encapsulation is a promising approach to delivering plant extract and potential probiotics in yogurt drink, protecting the bioactive compounds and L. paracasei during storage, and improving sensory attributes.

\section{ACKNOWLEDGEMENTS}

Marluci P. da Silva thanks the São Paulo Research Foundation (FAPESP) for the scholarship awarded (grant \#2016/24895-5 and grant \#2019/09757-3) and Coordenação de Aperfeiçoamento de Pessoal de Nível Superior - Brazil (CAPES) - Finance Code 001. Favaro- 
Trindade also thanks Conselho Nacional de Desenvolvimento Científico e Tecnológico (CNPq) for the productivity grant (Process \#305115/2018-9).

\section{REFERENCES}

AINSWORTH, E.; GILLESPIE, K. Estimation of total phenolic content and other oxidation substrates in plant tissues using Folin-Ciocalteu reagent. Nature Protocols, v. 2, p. 875-877, 2007.

AOAC. (2000). Official Methodos of Analysis of AOAC (17th ed.). Gaithersburg, MD, USA: AOAC International.

AOAC. (2005). Official Methods of Analysis of AOAC (18th ed.). Gaithersburg, MD, USA: AOAC International.

CHAIKHAM, P. Stability of probiotics encapsulated with Thai herbal extracts in fruit juices and yoghurt during refrigerated storage. Food Bioscience, v. 12, p. 61-66, 2015.

CHÁVARRI, M. et al. Microencapsulation of a probiotic and prebiotic in alginate-chitosan capsules improves survival in simulated gastro-intestinal conditions. International Journal of Food Microbiology, v. 142, p. 185-189, 2010.

COMUNIAN, T. A. et al. Development of functional yogurt containing free and encapsulated echium oil, phytosterol and sinapic acid. Food Chemistry, v. 237, p. 948-956, 2017.

FAVARO-TRINDADE, C. S.; HEINEMANN, R. J. B.; PEDROSO, D. L. Review: Developments in probiotic encapsulation. Perspectives in Agriculture, Veterinary Science, Nutrition and Natural Resources, v.6, p.1-8, 2011. 
GAUDREAU, H. et al. Co-encapsulation of Lactobacillus helveticus cells and green tea extract: Influence on cell survival in simulated gastrointestinal conditions. Journal of Functional Foods, v. 26, p. 451-459, 2016.

GAUDREAU, H. et al. Effect of catechins on the growth of oxygen-sensitive probiotic bacteria. Food Research International, v. 53, p. 751-757, 2013.

GEORGAKOULI, K. et al. The Effects of an Olive Fruit Polyphenol-Enriched Yogurt on Body Composition, Blood Redox Status, Physiological and Metabolic Parameters and Yogurt Microflora. Nutrients, v. 8, 344, 2016.

GIBSON, G.R. et al. The International Scientific Association for Probiotics and Prebiotics (ISAPP) consensus statement on the definition and scope of prebiotics. Nature Reviews Gastroenterology \& Hepatology, v. 14, p. 491-502, 2017.

HILL, C. et al. The International Scientific Association for Probiotics and Prebiotics consensus statement on the scope and appropriate use of the term probiotic. Nature Reviews Gastroenterology \& Hepatology, v. 11, p. 506-514, 2014.

HOLKEM, A. T. et al. Sugarcane Juice with Co-encapsulated Bifidobacterium animalis subsp. lactis BLC1 and Proanthocyanidin-Rich Cinnamon Extract. Probiotics and Antimicrobial Proteins, v. 12, p. 1179-1192, 2020.

KADRI, H. E. et al. Utilisation of water-in-oil-water (W1/O/W2) double emulsion in a set-type yogurt model for the delivery of probiotic Lactobacillus paracasei. Food Research International, 107, p. 325-336, 2018.

KAILASAPATHY, K. Survival of free and encapsulated probiotic bacteria and their effect on the sensory properties of yoghurt. LWT - Food Science and Technology, v. 39, p. 1221-1227, 2006.

KLEIN, T. et al. Microparticles containing guaraná extract obtained by spray-drying technique: development and characterization. Revista Brasileira de Farmacognosia, v. 25, p. 292-300, 2015. 
KLEIN, T.; LONGHINI, R.; MELLO, J. C. P. Development of an analytical method using reversed-phase HPLC-PDA for a semipurified extract of Paullinia cupana var. sorbilis (guaraná). Talanta, 88, 502-506, 2012.

LEE, H. M.; LEE, Y. A differential medium for lactic acid-producing bacteria in a mixed culture. Letters in Applied Microbiology, v. 46, p. 676-681, 2008.

MAJHENIC, L.; SKERGET, M.; KNEZ, Z. Antioxidant and antimicrobial activity of guaraná seed extracts. Food Chemistry, v. 104, p. 1258-1268, 200.

MANACH, C. et al. Polyphenols: food sources and bioavailability. The American Journal of Clinical Nutrition, v. 79, p. 727-747, 2004.

MATOS-JR, F. E. et al. Evaluation of the viability and the preservation of the functionality of microencapsulated Lactobacillus paracasei BGP1 and Lactobacillus rhamnosus 64 in lipid particles coated by polymer electrostatic interaction. Journal of Functional Foods, v. 54, p. 98$108,2019$.

MEILGAARD, M.; CIVILLE, G. V.; CARR, B. T. Sensory evaluation techniques. 3rd ed. Boca Raton: CRC Press, 1999. 390 p.

SANTANA, A. L.; MACEDO, G. A. Effects of hydroalcoholic and enzyme-assisted extraction processes on the recovery of catechins and methylxanthines from crude and waste seeds of guaraná (Paullinia cupana). Food Chemistry, v. 281, p. 222-230, 2019.

SCHIMPL, F. C. et al. Guaraná: Revisiting a highly caffeinated plant from the Amazon. Journal of Ethnopharmacology, v. 150, p. 14-31, 2013.

SHINDE, T.; SUN-WATERHOUSE, D.; BROOKS, J. Co-extrusion encapsulation of probiotic Lactobacillus acidophilus alone or together with apple skin polyphenols: an aqueous and valueadded delivery system using alginate. Food and Bioprocess Technology, v. 7, p. 1581-1596, 2014. 
SHUMOW, L.; BODOR, A. An industry consensus study on an HPLC fluorescence method for the determination of $( \pm)$-catechin and $( \pm)$-epicatechin in cocoa and chocolate products.

Chemistry Central Journal, v. 5, p. 1-7, 2011.

SILVA, M. P. et al. Production and characterization of solid lipid microparticles loaded with guaraná (Paullinia cupana) seed extract. Food Research International, v. 123, p. 144-152, 2019.

SILVA, M. P. et al. Application of spray chilling and electrostatic interaction to produce lipid microparticles loaded with probiotics as an alternative to improve resistance under stress conditions. Food Hydrocolloids, v. 83, p. 109-117, 2018.

SILVA, G. S. et al. Chemical profiling of guaraná seeds (Paullinia cupana) from different geographical origins using UPLC-QTOF-MS combined with chemometrics. Food Research International, v. 102, p. 700-709, 2017.

SINGLETON, V. L.; ORTHOFER, R.; LAMUELA-RAVENTOS, R. M. Analysis of total phenols and other oxidation substrates and antioxidants by means of Folin-ciocalteu reagent. Methods of Enzymology, v. 299, p. 152-178, 1999.

SOUZA, V. B. et al. Microencapsulation by complex coacervation as a tool to protect bioactive compounds and to reduce astringency and strong flavor of vegetable extracts. Food Hydrocolloids, v. 98, 105244, 2020.

SOUZA, V. B. et al. Functional properties and encapsulation of a proanthocyanidin-rich cinnamon extract (Cinnamomum zeylanicum) by complex coacervation using gelatin and different polysaccharides. Food Hydrocolloids, v. 77, p. 297-306, 2018.

SUZUKI, T., WALLER, G. R. Biosynthesis and biodegradation of caffeine, theobromine, and theophylline in Coffea arabica L. fruits. Journal of Agricultural and Food Chemistry, v. 32, p. 845-848, 1984.

WANG, K.; KRISTO, E.; LAPOINTE, G. Adding apple pomace as a functional ingredient in stirred-type yogurt and yogurt drinks. Food Hydrocolloids, v. 100, 105453, 2020. 
YONEKURA, L. et al. Bioavailability of catechins from guaraná (Paullinia cupana) and its effect on antioxidant enzymes and other oxidative stress markers in healthy human subjects. Food \& Function, v. 7, p. 2970-2978.

ZHAO, M. et al. (2020). Probiotic encapsulation in water-in-water emulsion via heteroprotein complex coacervation of type-A gelatin/sodium caseinate. Food Hydrocolloids, v. 105, 105790. 
5 CHAPTER 4 - DEVELOPMENT OF FUNCTIONAL PEANUT BUTTER CONTAINING FREE AND ENCAPSULATED PROBIOTIC AND GUARANÁ PEEL EXTRACT 


\title{
5 CHAPTER 4 - DEVELOPMENT OF FUNCTIONAL PEANUT BUTTER CONTAINING FREE AND ENCAPSULATED PROBIOTIC AND GUARANÁ PEEL EXTRACT
}

\begin{abstract}
The valorization of guaraná peels to recover carotenoids combining with probiotics could fortify food matrices as functional ingredients. This study focused on the co-encapsulation of Bifidobacterium animalis subsp. lactis BLC-1 and GPE for application in peanut butter. Also, the influence of free and encapsulated probiotic added in peanut butter was evaluated through the sensorial acceptance and stability of the product during storage. Co-encapsulation protected carotenoids and improved probiotic viability. Furthermore, the incorporation of microcapsules in peanut butter maintained its texture and quality parameters. Peanut butter containing microcapsules loaded with probiotic and GPE reached the highest viability, approximately $7.8 \log$ CFU/g after 90 days of storage at $25^{\circ} \mathrm{C}$. Peanut butter added of free GPE and probiotic showed the lowest overall acceptability and purchase intention, which justifies the importance of encapsulation to mask the bitter taste of GPE. Overall, co-encapsulation is a promising procedure to preserve and add multiple compounds in food matrices maintaining their quality parameters.
\end{abstract}

Keywords: co-encapsulation, probiotic, agro-industrial waste, carotenoids, tocopherol, sensory analysis 


\subsection{INTRODUCTION}

Agro-industrial waste is an environmental and economic problem for companies and for communities that surround them. In this way, Brazil is the largest provider of guaraná fruit globally, which its seeds are explored to extract caffeine to develop natural stimulant products. We estimated that around $50 \%$ of the guaraná fruit is discarded, mainly its peel, during guaraná seeds processing. However, guaraná peels are a good source of bioactive compounds, such as carotenoids and methylxanthines (PINHO et al., 2021). In addition, guaraná peels extract demonstrated to be a potential prebiotic since it extended the viability of probiotic populations during in vitro incubation (Silva et al., reviewing).

Carotenoids are lipophilic pigments covering colors between yellow and red found in nature, providing some health benefits, such as antioxidant, antihypertensive, and antiinflammatory potential (KRINSKY; JOHNSON, 2005). In this way, the food industry mainly uses carotenoids as a natural colorant and functional ingredient. However, their application in food can be a challenge, considering the insolubility in water and the susceptibility to oxidation and isomerization (RODRIGUEZ-AMAYA, 2019). In this context, microencapsulation may protect carotenoids from harsh conditions and enhances their bioaccessibility (SANTOS et al., 2021a).

The simultaneous encapsulation of carotenoids and probiotics could improve the viability of probiotics during storage by the antioxidant capacity of carotenoids, reducing the oxidative stress of probiotics. Few studies showed the positive influence of the combination of probiotics and carotenoids, indicating the anti-inflammatory effect in adjuvant arthritis in rats (AL-OKBI et al., 2011) and the enhancement of carotenoids content due to the probiotic fermentation in vegetable juice (CHUNG et al., 2020, XU et al., 2020). In this context, there is a lack of studies regarding the preservation of probiotic combined with carotenoids in microcapsules, demonstrating the relevance of this investigation.

Among the encapsulation techniques, complex coacervation showed excellent protection for carotenoids (GOMEZ-ESTACA et al., 2016) and probiotic cells (SILVA et al., 2018). In addition, some studies demonstrated that simultaneous encapsulation by complex coacervation is an efficient strategy to fortify food matrices, such as yogurt containing co-encapsulated echium oil and phytosterols (COMUNIAN et al., 2017) and a sugarcane juice supplemented with 
microcapsules loaded with probiotics and cinnamon extract (HOLKEM et al., 2020). However, the simultaneous encapsulation of lipophilic plant extract and probiotic, applying the microcapsules in the food matrix remains unexplored.

Dairy food products are widely used to apply microcapsules due to the high compatibility of probiotics and hydrophilic materials used as encapsulant materials. Nevertheless, there is a growing demand for non-dairy foods supplemented with probiotics for special audiences. In this way, lipid food matrices emerge as an alternative to fermented beverages, such as kefir and kombucha, expanding the options for these audiences. Furthermore, another study evaluated the chocolate to incorporate probiotics, displaying high survivability during the storage of chocolate (SILVA et al., 2017).

Peanut butter is a prospective food matrix for applying probiotics since it is accepted worldwide, showing varied formulations, such as sweetened, no sugar, smooth and crunchy. Also, the texture of this product containing peanut particles could avoid the perception of microcapsules in the mouth. For this reason, the inquiry of peanut butter containing free and encapsulated probiotics could contribute regards the influence of food matrix, encapsulation, and the application of GPE on the survivability of probiotic cells during storage of peanut butter. Based on these issues, the overall goals of this study were (i) to co-encapsulate GPE and Bifidobacterium animalis subsp. lactis BLC-1 by complex coacervation; (ii) to characterize the microcapsules; (iii) to develop functional peanut butter containing free and encapsulated probiotic and GPE; (iv) to evaluate the sensorial acceptance of peanut butter formulations and the quality parameters during storage of 90 days at $25^{\circ} \mathrm{C}$.

\subsection{MATERIAL AND METHODS}

\subsubsection{Materials}

Gelatin (pI 4) and Arabic gum were purchased from Gelita South America (Mococa, Brazil) and Nexira (São Paulo, Brazil), respectively. Guaraná fruit and Bifidobacterium animalis subsp. lactis BLC-1 were donated by the Executive Commission of the Rural Economic Recuperation Plan in Cacao (Taperoá, Brazil) and Sacco (Campinas, Brazil), respectively. Peanut butter was kindly provided by Vô Nico Co. (Pirassununga, Brazil). 


\subsubsection{Production of guaraná peel extract}

Guaraná was peeled off manually, and then it was washed with water to remove the dirt. It was sanitized using a chlorine solution $(3 \mathrm{ppm})$ for $2 \mathrm{~min}$. Peel was dried in a tray dryer at $50{ }^{\circ} \mathrm{C}$ for $24 \mathrm{~h}$. Dried peel was milled using a blender, and the particle size was standardized using a sieve $(<1 \mathrm{~mm})$. Extraction was performed using a water bath, protected from the light, at $50{ }^{\circ} \mathrm{C}$ for $2 \mathrm{~h}$. Thus, the milled peel was put in contact with absolute ethanol in the proportion 1:10 (w/v) and kept under mechanical stirring. Ethanol was evaporated entirely at $45^{\circ} \mathrm{C}$. In this step, $3 \%$ (w/v) of sunflower oil was added to guaraná peel extract to protect the carotenoids. Finally, it was obtained concentrated oil with carotenoids.

\subsubsection{Total carotenoid content (TC)}

Approximately $0.5 \mathrm{~g}$ of guaraná peels extract was added to $5 \mathrm{~mL}$ of hexane. Then, the mixture was agitated using a vortex, followed by the ultrasound extraction for 5 min and separation of organic phase by centrifugation at $5000 \mathrm{rpm}$ for $5 \mathrm{~min}$. The absorbance of the organic phase was read using a spectrophotometer at $450 \mathrm{~nm}$. Total carotenoid content was calculated using this equation:

$$
T C(\mu g / m l)=\frac{\text { Absorbance } \times \text { Volume }(\mathrm{ml}) \times 10^{4}}{\text { Absorption coef } \times \text { Sample weight }(g)}
$$

Where: absorption coefficient of 2500, which is recommended for mixtures (RODRIGUEZAMAYA; KIMURA, 2004).

\subsubsection{Preparation of probiotic inoculum}

Approximately $10 \mathrm{mg}$ of freeze-dried B. animalis subsp. lactis BLC-1 was activated in 10 mL MRS (de Man, Rogosa and Sharpe) broth and incubated at $37^{\circ} \mathrm{C}$ for $18 \mathrm{~h}$. Then, the cultivated broth was added in $90 \mathrm{~mL}$ of MRS broth and incubated under the same conditions. Finally, probiotic cells were collected by centrifugation $\left(7000 \mathrm{rpm}, 10^{\circ} \mathrm{C}, 5 \mathrm{~min}\right)$. 


\subsubsection{Encapsulation of probiotic and co-encapsulation of probiotic and GPE}

Probiotic was encapsulated using a gelatin solution (2.5\%) and Arabic gum (2.5\%) in proportion 1:1, as described by Silva et al. (2019), with some modifications. Control microcapsules were produced using only the polymers and probiotic cells to evaluate the influence of GPE on the viability of probiotic. Probiotic pellet was added in gelatin solution, followed by homogenization using Ultra-Turrax IKA T-25 (Campinas, Brazil) at $9000 \mathrm{rpm}$ for $90 \mathrm{~s}$. Then, an Arabic gum solution was added to the mixture and kept under magnetic stirring, and the $\mathrm{pH}$ was adjusted to 4 (citric acid, $5 \mathrm{M}$ ).

Regarding the simultaneous encapsulation of probiotic and guaraná peels extract, the probiotic pellet was added in concentrated guaraná peels extract. It was mixed using an UltraTurrax at $6000 \mathrm{rpm}$ for $60 \mathrm{~s}$. The mixture was added in gelatin solution and homogenized at 9000 rpm for $90 \mathrm{~s}$, followed by adding Arabic gum solution and adjusting $\mathrm{pH}$ to 4.2. Both formulations were frozen at $-18{ }^{\circ} \mathrm{C}$ and freeze-dried (Terroni, Sao Carlos, Brazil) for $24 \mathrm{~h}$. Finally, powders were characterized before their application in peanut butter.

\subsubsection{Characterization of microcapsules}

\subsubsection{Morphology and particle size distribution}

Microcapsules were evaluated regarding the morphology using a Leica DM500 microscopy equipped with a camera ICC50 W (Leica, Germany) at a magnification of x100. Also, microcapsules were dispersed in water to measure the particle size distribution by laser diffraction (Sald-201V, Shimadzu, Japan).

\subsubsection{Quantification of TC in free GPE and microcapsules during storage}

The stability of encapsulated carotenoids was achieved during storage at $7{ }^{\circ} \mathrm{C}$ and $25{ }^{\circ} \mathrm{C}$ for 90 days. Concerning the free GPE, it was stored at $25{ }^{\circ} \mathrm{C}$ for 90 days. Free GPE and microcapsules were stored in glass jar without the protection of light. First, microcapsules were disrupted using a $2 \%(\mathrm{w} / \mathrm{v})$ sodium citrate solution, previously heated at $40{ }^{\circ} \mathrm{C}$, and maintained in a water bath for $5 \mathrm{~min}$, followed by the addition of $3 \mathrm{~mL}$ of hexane. For free GPE, this procedure 
was similar, but it was not necessary to apply sodium citrate solution, only $1 \mathrm{~mL}$ of distilled water for phase separation. Lidded tubes were submitted in ultrasound for $5 \mathrm{~min}$, and the organic phase was separated by centrifugation $\left(25^{\circ} \mathrm{C}, 5000 \mathrm{rpm}, 5 \mathrm{~min}\right)$. An exhaustion extraction procedure was performed three times to complete the removal of the yellow color of microcapsules. TC was calculated by spectrophotometer as described in section 5.2.3.

\subsubsection{Enumeration of encapsulated probiotic during storage}

Microcapsules were disrupted for the liberation of probiotic cells; about $0.1 \mathrm{~g}$ of microcapsules were added to $9.9 \mathrm{ml}$ of $2 \%$ sodium citrate solution. Then, tubes were homogenized using a Multi Reax Vortex (Heidolph, Schwabach, Germany) for 10 min. Finally, an aliquot was removed for serial dilution, followed by the inoculation onto MRS agar. Petri dishes were incubated in an anaerobic jar at $37^{\circ} \mathrm{C}$ for 2 days. Viability of encapsulated probiotic was performed after $0,15,30,60$ and 90 days of storage at $7{ }^{\circ} \mathrm{C}$ and $25^{\circ} \mathrm{C}$.

\subsubsection{Application of microcapsules in peanut butter}

Production of peanut butter was performed at the Vo Nico Co. (Pirassununga, Brazil) following good manufacturing practices. Roasted peanut was grounded using a mill and separated into five parts to add the free and encapsulated probiotic and GPE. The proportion of $1.5 \%(\mathrm{w} / \mathrm{w})$ of microcapsules was added to the peanut butter. In contrast, the ratio of the free probiotic and GPE added to the peanut butter was equivalent to that loaded into the microcapsules. Thus, five peanut butter formulations were developed: peanut butter containing the free probiotic cells (PBF), the encapsulated probiotic (PBE), the free probiotic cells and GPE (PBGF), and co-encapsulated probiotic and GPE (PBGE). In addition, control formulation, without adding other ingredients, was prepared to evaluate the quality of peanut butter. 


\subsubsection{Quality parameters of peanut butter formulations}

\subsubsection{Physical-chemical properties: physicochemical characterization, water activity} $\left(\mathrm{A}_{\mathrm{w}}\right), p H$, color, texture parameters

The physicochemical characterization of peanut butter formulations was performed according to the AOAC (2005) regarding the total solids, ash, protein, lipid, carbohydrate, and crude fiber.

The water activity $\left(\mathrm{A}_{\mathrm{w}}\right)$ of peanut butter was measured using an Aqualab Pre Water Activity Analyzer (Decagon Devices Inc., USA) stabilized at $25^{\circ} \mathrm{C}$.

The $\mathrm{pH}$ of formulations was performed as suggested by Silva et al. (2017). Approximately $10 \mathrm{~g}$ of each peanut butter formulation was added in $100 \mathrm{~mL}$ of ultrapure water, keeping the magnetic stirring around $10 \mathrm{~min}$. After, the $\mathrm{pH}$ was evaluated using a pH meter (Marte MB10, São Paulo, Brazil) of peanut butter formulations stored at $25^{\circ} \mathrm{C}$ for up to 90 days.

The total color difference ( $\Delta \mathrm{E}$ ) of peanut butter formulations was calculated (Eq. 2), given the CIELAB color measurement on the first day and last day of storage. Thus, color parameters of peanut butter were measured using a HunterLab Mini Scan XE Plus colorimeter (Hunter Associates Laboratory Inc., Reston, USA).

$$
\Delta E=\sqrt{\left[\left(L_{2}^{*}-L_{1}^{*}\right)^{2}+\left(a_{2}^{*}-a_{1}^{*}\right)^{2}+\left(b_{2}^{*}-b_{1}^{*}\right)^{2}\right]} \quad \text { Eq. (2) }
$$

Penetration test was performed using a cylindrical probe $(\phi=2.5 \mathrm{~cm})$ at the texturometer (TA XT Plus Texture Analyzer, Extralab, Brazil) equipped with a 5-kg load cell, penetrating $4 \mathrm{~mm}$ at $0.5 \mathrm{~mm} / \mathrm{s}$ and retracted until it breaks completely (AHMED; ALI, 1986; TANTI et al., 2016). The formulations were placed in a glass beaker 35 x $25 \mathrm{~mm}$ (Diameter x Depth). Textural parameters were obtained from the force-deformation curve, such as the firmness that is the maximum force of penetration expressed as Newtons $(\mathrm{N})$, adhesion is the maximum force of withdrawal $(\mathrm{N})$, work of penetration $\left(\mathrm{N}^{*} \mathrm{~s}\right)$, and adhesiveness $\left(\mathrm{N}^{*} \mathrm{~s}\right)$. 


\subsubsection{Evaluation of oxidation by thiobarbituric acid reactive substances (TBARS)}

The high lipid content of peanut butter makes it susceptible to oxidation, which could reduce its shelf life. Thus, the lipid oxidation was assessed according to Vyncke (1970), with some modifications. About $2 \mathrm{~g}$ of peanut butter was added to $10 \mathrm{~mL}$ of $7.5 \%$ trichloroacetic acid (TCA) solution and homogenized using a Multi Reax Vortex for $1 \mathrm{~min}$, following by filtration. Then, 5 $\mathrm{mL}$ of thiobarbituric acid (TBA) $0.02 \mathrm{M}$ was added to $5 \mathrm{~mL}$ of the filtered mixture and kept in a water bath at $90{ }^{\circ} \mathrm{C}$ for $45 \mathrm{~min}$. Samples were cooled using an ice bath and centrifuged $\left(25^{\circ} \mathrm{C}\right.$, $7000 \mathrm{rpm}$ for $10 \mathrm{~min}$ ). The absorbances were measured using a spectrophotometer at $532 \mathrm{~nm}$.

\subsubsection{Quantification of total phenolic compounds (TPC) and $\alpha$-tocopherol in peanut} butter formulations

First, peanut butter samples were defatted twice as described by Alañón et al. (2016). Thus, the lipidic phases were used to quantify tocopherols, while the defatted samples were assessed to TPC. For this, $2 \mathrm{~g}$ of peanut butter was added to $10 \mathrm{ml}$ of hexane and homogenized by agitation followed by sonication for $5 \mathrm{~min}$. Then, samples were centrifugated at $5000 \mathrm{rpm}$ for $5 \mathrm{~min}$ and residual hexane was removed by air-dried. Finally, phenolic compounds were extracted from samples twice to ensure the maximum release, using $1 \mathrm{~g}$ of defatted peanut butter added to $10 \mathrm{ml}$ of ethanol solution $(80 \% \mathrm{v} / \mathrm{v})$. This mixture was homogenized by sonication for $10 \mathrm{~min}$, followed by centrifugation at $5000 \mathrm{rpm}$ for $5 \mathrm{~min}$.

TPC was determined as suggested by Singleton, Orthofer, and LamuelaRaventos (1999) and Souza et al. (2014), using $0.25 \mathrm{ml}$ of the peanut butter extracts added to $2 \mathrm{ml}$ of distilled water and $0.25 \mathrm{ml}$ of Folin-Ciocalteu reagent. Tubes rested 3 min protected from the light at room temperature, $0.25 \mathrm{ml}$ of saturated sodium carbonate solution $\left(\mathrm{Na}_{2} \mathrm{CO}_{3}\right)$ was added to the mixture and homogenized. Samples were maintained in a water bath protected from the light at $37{ }^{\circ} \mathrm{C}$ for $30 \mathrm{~min}$ to complete the reaction. The absorbance was measured at $750 \mathrm{~nm}$ using a UV-vis spectrophotometer Genesys 10S (Thermo Scientific, Sao Paulo, Brazil). The total content of

phenolic compounds was determined using gallic acid as standard, expressing as mg of gallic acid equivalent $-\mathrm{GAE} / \mathrm{g}$ of peanut butter. 
The remaining lipids of the peanut butter defatted procedure were evaluated regarding the tocopherols contents by high-performance liquid chromatography (HPLC), as Tulini et al. (2016) proposed. The HPLC system (Shimadzu, Japan) was coupled with a C18 column $(5 \mu \mathrm{m}, 4.6 \times 250$ mm, Shim-pack VP-ODS, Shimadzu) and a fluorescence detector (290 nm excitation, $330 \mathrm{~nm}$ emission) maintained at $35{ }^{\circ} \mathrm{C}$, injecting $10 \mu \mathrm{l}$ of sample for analysis. The mobile phase was composed of methanol: water: acetonitrile (90:6:4 v/v) at a flow rate of $0.9 \mathrm{~mL} / \mathrm{min}$ for $20 \mathrm{~min}$. Quantification was carried out using $\alpha$-tocopherol (Sigma-Aldrich, USA) standard solution.

\subsubsection{Viability of probiotic in peanut butter during storage}

Peanut butter formulations were stored in polypropylene jars at $25{ }^{\circ} \mathrm{C}$ for 90 days. The enumeration of probiotic in peanut butter was evaluated as suggested by Silva et al. (2017). Approximately $5 \mathrm{~g}$ of peanut butter was added to $45 \mathrm{~mL}$ of sodium citrate $2 \%$ solution, previously harmed at $40{ }^{\circ} \mathrm{C}$, then homogenized for $2 \mathrm{~min}$ in a stomacher. Then, serial dilution was carried out, inoculating aliquots onto MRS agar. Inoculated plates were incubated in an anaerobic jar at $37^{\circ} \mathrm{C}$ for $48 \mathrm{~h}$.

\subsubsection{Acceptance sensory test, profile of panelists and purchase intention}

Acceptance sensory test was applied to 127 untrained panelists ( 79 women and 48 men), according to Meilgaard, Civille, and Carr (1991), at the Sensory Analysis Lab in the Department of Food Engineering at Universidade de Sao Paulo, Pirassununga, Brazil. First, panelists answered a consumer questionnaire to examine their profile (age, frequency of eating peanut butter, preferred type of peanut butter) and which important aspect of buying it. Then, formulations were served individually with water and a regular cracker to clean the palate between the samples. Panelists were asked about the aroma, color, taste, texture, spreadability, and overall acceptability, considering the 9-point hedonic scale (1 - dislike extremely and 9-like extremely). Besides that, they were asked about the purchase intention of each formulation. 


\subsection{RESULTS AND DISCUSSION}

\subsubsection{Characterization of microcapsules during the storage at $7^{\circ} \mathrm{C}$ and $25^{\circ} \mathrm{C}$}

\subsubsection{Morphology, particle size distribution, total carotenoid content (TC) and viability} of encapsulated probiotic

Figure 14 displays the micrographs of rehydrated microcapsules loaded with probiotic or microcapsules loaded simultaneously with probiotic and GPE, showing that both microcapsules were spherical with variable sizes. Also, the micrograph confirmed the microencapsulation of GPE since the yellow lipidic nucleus were evidenced and covered by polymers.

Figure 14 - Micrographs of microcapsules produced by complex coacervation using an objective with 10x, and particle size distribution. In this Figure: (A) Control microcapsules composed by gelatin/Arabic gum and Bifidobacterium animalis subsp. lactis BLC-1, (B) microcapsules composed by gelatin/Arabic gum, B. animalis subsp. lactis BLC-1 and guaraná peel extract (GPE), and (C) particle size distribution of microcapsules.

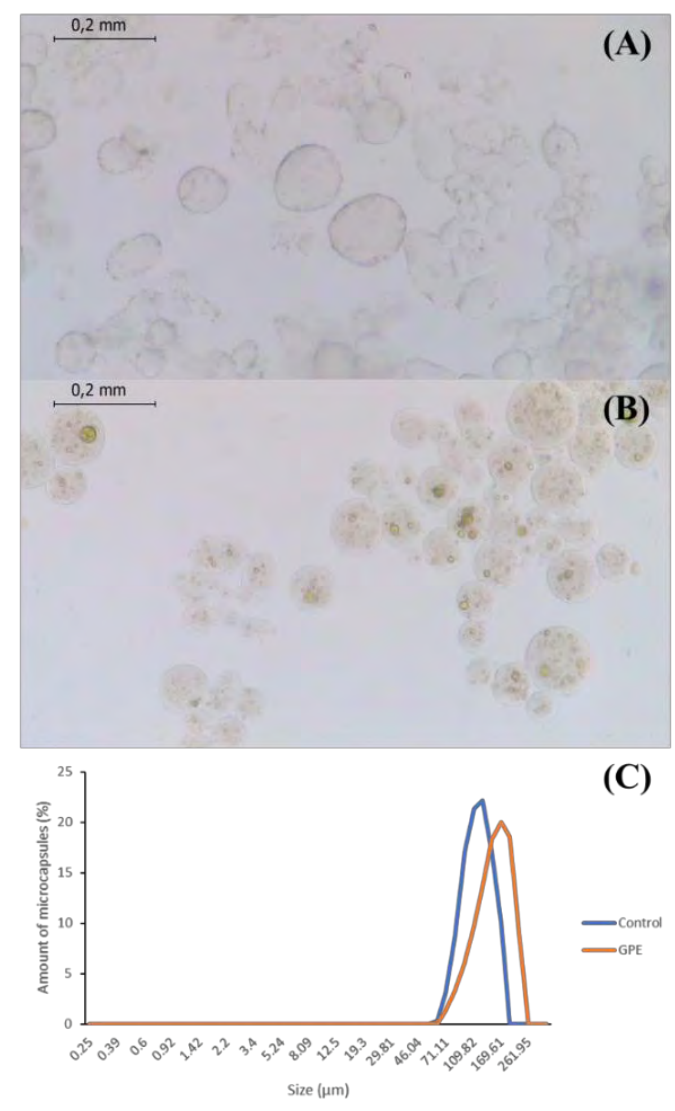

Reference: Own source. 
The particle size distribution for control microcapsules varied from 61 to $170 \mu \mathrm{m}$, as for microcapsules loaded with probiotic and GPE was between 71 to $226 \mu \mathrm{m}$ (Figure $14 \mathrm{C}$ ). These results were expected since the association of GPE and probiotics increased the core materials, hence the average particle size. Furthermore, another study verified that simultaneous encapsulation of phytosterols and probiotics increased the particle size (SHARIFI et al., 2021). Thus, the co-encapsulation implies the increment of particle size, which could affect the application of microcapsules in some food matrices. However, the physicochemical properties of peanut butter, in which the solid peanut particles are dispersed in peanut oil (CITERNE; CARREAU; MOAN, 2001), providing an interesting matrix for the addition of these microcapsules.

Figure 15 (A, B) displayed the TC in microcapsules and free GPE stored at $25^{\circ} \mathrm{C}$ and $7{ }^{\circ} \mathrm{C}$ for 90 days. Initially, GPE showed around $420 \mu \mathrm{g}$ of total carotenoids/g of extract, decreasing the TC approximately to $200 \mu \mathrm{g} / \mathrm{g}$ of extract during the storage at $25{ }^{\circ} \mathrm{C}$ since carotenoids are susceptible to oxidation by light and oxygen. It is essential to highlight those microcapsules and free GPE were stored in a glass jar without the protection of light, which reproduces a more severe condition for carotenoids stability. In this way, the retention of carotenoids in GPE was around $43 \%$, demonstrating the relevance of protection by microencapsulation. Microcapsules loaded with probiotic and GPE showed a TC of approximately $45 \mu \mathrm{g} / \mathrm{g}$ at the beginning of storage, maintaining this TC for powder stored at $7{ }^{\circ} \mathrm{C}$. In contrast, microcapsules stored at $25^{\circ} \mathrm{C}$ at the end of storage exhibited TC of about $30 \mu \mathrm{g} / \mathrm{g}$, indicating that storage temperature also affected the preservation of total carotenoids. However, the microencapsulation protected the total carotenoids from GPE during the storage, showing higher retentions about $65 \%$ and $99 \%$ for microcapsules stored at 25 ${ }^{\circ} \mathrm{C}$ and $7{ }^{\circ} \mathrm{C}$, respectively. Also, the storage temperature influenced the preservation of encapsulated carotenoids, with its increment, carotenoid retention in microcapsules decreased, as supported by another study (CHUYEN et al., 2019).

Similarly, Santos et al. (2021b) evaluated the retention of carotenoids in encapsulated Tucumã oil by spray drying using Arabic gum as a carrier. After 100 days of storage at $25{ }^{\circ} \mathrm{C}$, carotenoids retention values ranged from $80 \%$ to $95 \%$, depending on the proportion of oil encapsulated. Authors indicated that microparticles loaded with less oil could be more porous, causing the degradation of carotenoids. Although the present study used another encapsulation 
technique and combined gelatin with Arabic gum to protect GPE, freeze-drying produces powders with high porosity due to the ice sublimation (OIKONOMOPOULOU; KROKIDA; KARATHANOS, 2011).

Figure 15 - Total carotenoids of free guaraná peel extract (GPE) stored at $25^{\circ} \mathrm{C}$ (graph A) and microcapsules loaded with Bifidobacterium animalis subsp. lactis BLC-1 (B) and GPE held at $7{ }^{\circ} \mathrm{C}$ and $25^{\circ} \mathrm{C}$ up to 90 days (graph B), and enumeration of encapsulated probiotics (graph C). In this Figure: yellow bars are unencapsulated GPE stored at $25^{\circ} \mathrm{C}$, yellow bars filled with dots are the microcapsules loaded with GPE and B. animalis subsp. lactis BLC1 (B) stored at $25^{\circ} \mathrm{C}$, black bars are the microcapsules loaded with GPE and B stored at $7{ }^{\circ} \mathrm{C}$, white bars are the microcapsules loaded with B stored at $25^{\circ} \mathrm{C}$, white bars filled with lines are the microcapsules loaded with B stored at $7^{\circ} \mathrm{C}$.

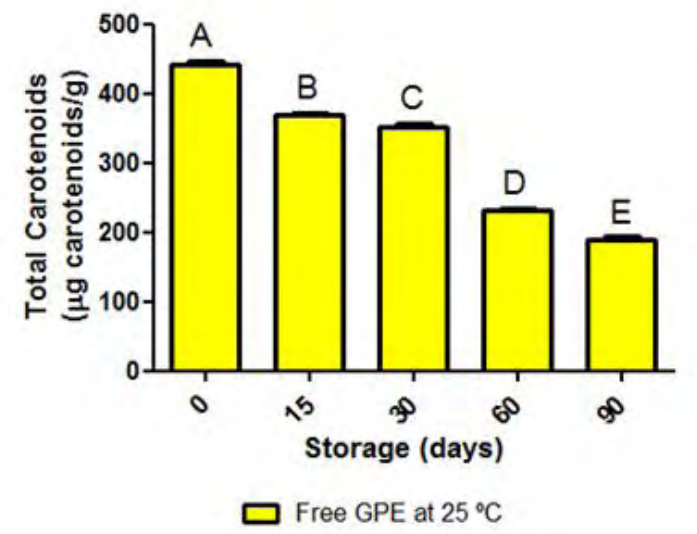

(A)

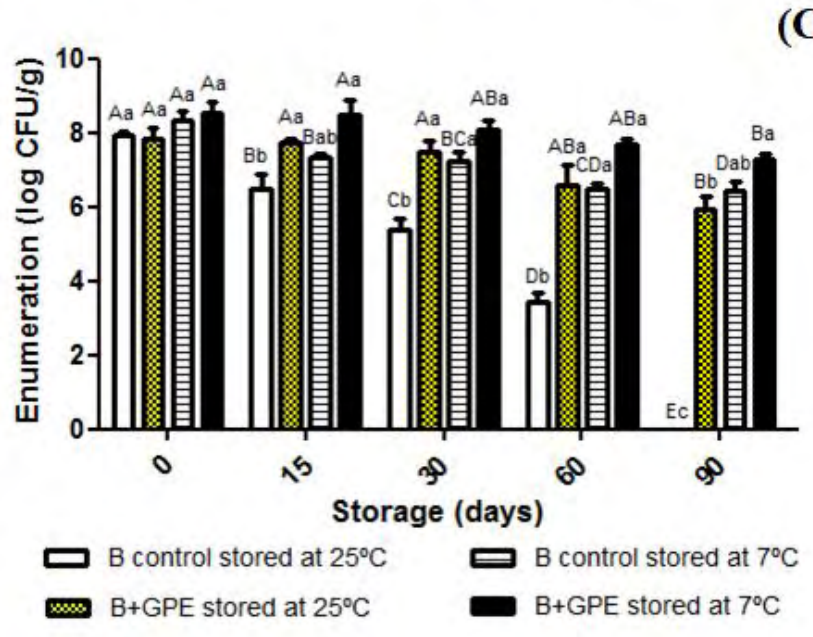

(B)

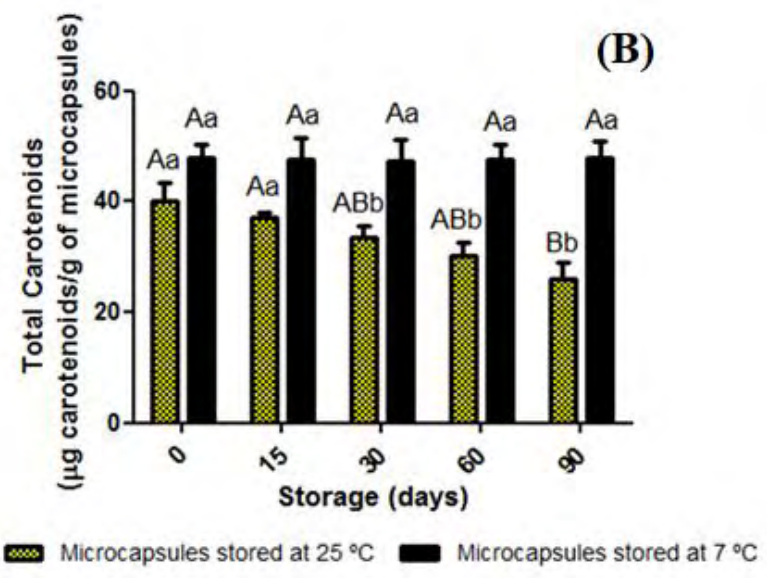

(C)

Bars identified by the same upper letters of the same treatments are not statistically different. Bars identified by the same lower letters in the same time interval are not statistically different $(p>0.05)$.

B. animalis subsp. lactis BLC-1 was encapsulated alone as a control to verify the role of GPE to maintain these microorganisms' viability during the storage. After freeze-drying microcapsules, the initial counts were around $8 \mathrm{log} \mathrm{CFU} / \mathrm{g}$ for all microcapsules, as shown in 
Figure 15 C. However, the encapsulated probiotic populations decreased over the storage, mostly the probiotic loaded in control microcapsules with populations below the method's detection limit (500 CFU/g). Based on these results, the co-encapsulation of probiotic with GPE was relevant to provide a count of around $6 \log \mathrm{CFU} / \mathrm{g}$ of powder stored at $25^{\circ} \mathrm{C}$ after 90 days. However, the final counts did not differ significantly for encapsulated probiotic loaded alone or simultaneously with GPE stored at $7{ }^{\circ} \mathrm{C}$, demonstrating the positive effect of the low temperature of storage to maintain the viability of probiotic.

The chemical composition of GPE, a source of carotenoids and phenolics, as evaluated previously by Pinho et al. (2021), may reduce the oxidative stress of probiotic, enhancing the viability of encapsulated probiotic stored at $25^{\circ} \mathrm{C}$. In addition, the low temperature of storage was efficient in reducing the probiotic metabolism, contributing to higher final counts than the microcapsules stored at $25{ }^{\circ} \mathrm{C}$. Similarly, another study verified that low storage temperature preserved the viability of encapsulated probiotic, indicating that co-encapsulation of probiotic with $5 \%$ of cinnamon extract improved the final viability (HOLKEM; FAVARO-TRINDADE, 2020). Although the mechanisms to preserve probiotics in microcapsules have not yet been fully elucidated, the co-encapsulation of probiotics and plant extracts seems to improve their survivability. In our case, freeze-drying microcapsules reduced the probiotic metabolism, indicating that GPE probably maintained the viability of probiotics due to the antioxidant potential.

\subsubsection{Characterization of peanut butter formulations stored at $25^{\circ} \mathrm{C}$ for 90 days}

\subsubsection{Proximate composition, water activity $\left(A_{w}\right), p H$, total color difference of the peanut} butter formulations

Concerning the effect of food matrix for the application of free and encapsulated probiotics, the proximate composition of peanut butter was evaluated, as exhibited in Table 9. All formulations showed as major compounds the lipids, varying from 51.7 to $54.5 \%$, followed by approximately $29 \%$ of proteins since these products were a no-sugar formulation that could increase carbohydrates and calories. The application of microcapsules in peanut butter contributed to a small increment of total carbohydrates. 
Table 9 - Proximate composition of functional peanut butter formulations.

\begin{tabular}{cccccc}
\hline Parameters & Control & PBF & PBE & PBGF & PBGE \\
& & & & & \\
\hline Total Solids (\%) & $98.94 \pm 0.16^{\mathrm{a}}$ & $98.96 \pm 0.13^{\mathrm{a}}$ & $98.98 \pm 0.15^{\mathrm{a}}$ & $98.88 \pm 0.09^{\mathrm{a}}$ & $98.68 \pm 0.05^{\mathrm{a}}$ \\
Ash (\%) & $2.02 \pm 0.02^{\mathrm{a}}$ & $1.99 \pm 0.02^{\mathrm{a}}$ & $1.96 \pm 0.10^{\mathrm{a}}$ & $2.00 \pm 0.04^{\mathrm{a}}$ & $2.00 \pm 0.02^{\mathrm{a}}$ \\
Protein (\%) & $28.98 \pm 0.01^{\mathrm{a}}$ & $28.59 \pm 0.08^{\mathrm{a}}$ & $29.33 \pm 0.23^{\mathrm{a}}$ & $28.90 \pm 0.38^{\mathrm{a}}$ & $28.81 \pm 0.25^{\mathrm{a}}$ \\
Lipids (\%) & $53.30 \pm 0.07^{\mathrm{ab}}$ & $53.85 \pm 0.20^{\mathrm{ab}}$ & $51.73 \pm 0.07^{\mathrm{c}}$ & $54.52 \pm 0.28^{\mathrm{a}}$ & $52.86 \pm 0.61^{\mathrm{bc}}$ \\
& & & & \\
Total & $8.34 \pm 0.02^{\mathrm{ab}}$ & $8.33 \pm 0.13^{\mathrm{ab}}$ & $10.06 \pm 0.24^{\mathrm{a}}$ & $7.43 \pm 0.60^{\mathrm{b}}$ & $9.54 \pm 1.16^{\mathrm{ab}}$ \\
carbohydrates (\%) & & & & & \\
Crude fiber (\%) & $7.37 \pm 0.10^{\mathrm{a}}$ & $7.26 \pm 0.16^{\mathrm{a}}$ & $6.93 \pm 0.02^{\mathrm{a}}$ & $7.16 \pm 0.06^{\mathrm{a}}$ & $6.79 \pm 0.30^{\mathrm{a}}$
\end{tabular}

Values with the same lower-case letter in a row are not statistically different ( $p>0.05)$. In this table, control is the regular peanut butter formulation, PBF is the peanut butter containing free probiotic, PBE is the peanut butter containing encapsulated probiotic, $\mathrm{PBGF}$ is the peanut butter containing with free probiotic and guaraná peel extract, and PBGE is the peanut butter containing co-encapsulated probiotic and guaraná peel extract.

The proximate composition is in accordance with another study that evaluated 17 varieties of peanut to produce peanut butter (GONG et al., 2018). One of the advantages of applying probiotics in peanut butter is that high content of fat could contribute to the maintenance of probiotic viability. Another study incorporated probiotics in chocolate, highlighting the protection of probiotics during storage and simulated gastrointestinal fluids (SILVA et al., 2017). Additionally, this study intended to assess the relevance of encapsulation to preserve the viability of probiotic over the storage.

Figure 16 shows the characterization of peanut butter formulations. Formulations containing free probiotic showed a slight increase of $\mathrm{pH}$, but the other formulations displayed the maintenance of the $\mathrm{pH}$, which is desirable for accepting these products. Nonetheless, the neutral $\mathrm{pH}$ of this product could contribute to the dissociation of polymers by the repulsive forces since gelatin and Arabic gum present a negative charge in this condition (ZHOU et al., 2018). However, the low humidity of this product probably hindered this process. 
Figure 16 - Characterization of peanut butter formulations during the storage, regarding $\mathrm{pH}$ (A), water activity - Aw (B), total phenolic content (C), $\alpha$-tocopherol content (D), oxidation by TBARS (E) and viability of probiotic (F). In this figure, control is the regular peanut butter formulation represented as blank bars, PBF is the peanut butter containing free probiotic represented as brown bar, PBE is the peanut butter containing encapsulated probiotic represented as brown bars filled with dots, PBGF is the peanut butter containing with free probiotic and guaraná peel extract represented as yellow bars, and PBGE is the peanut butter containing co-encapsulated probiotic and guaraná peel extract represented as yellow bar filled with dots.

(A)
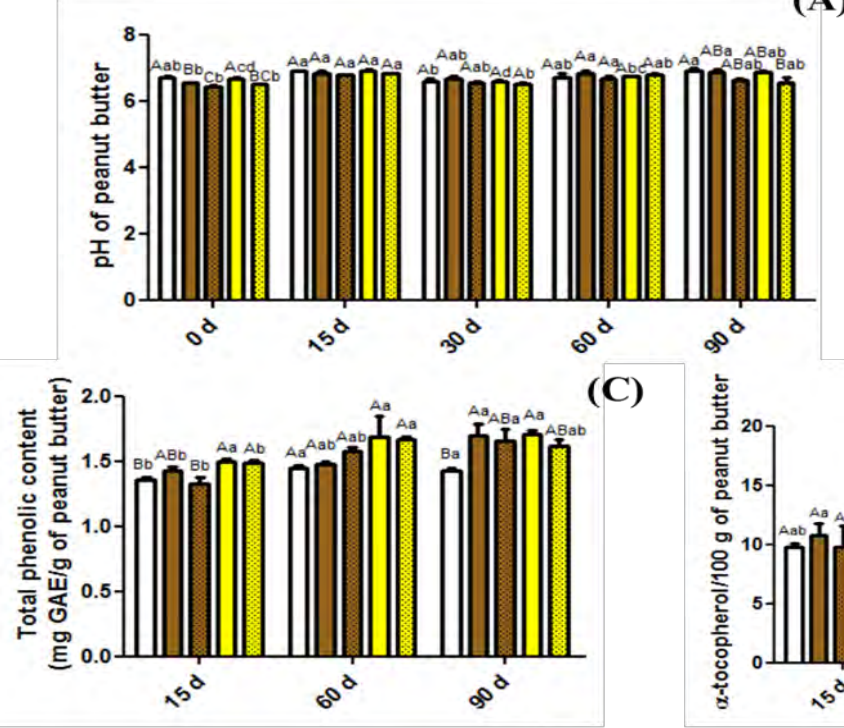

(C)
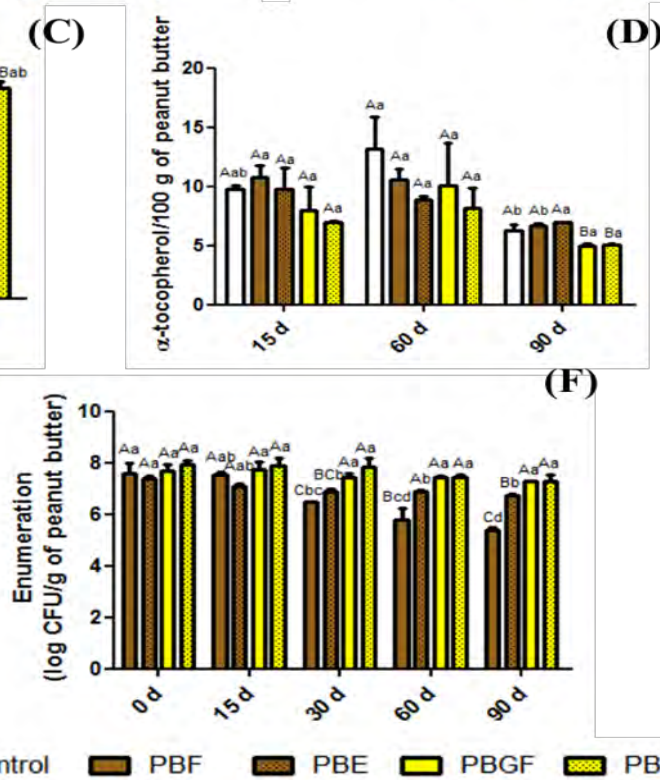

(B)

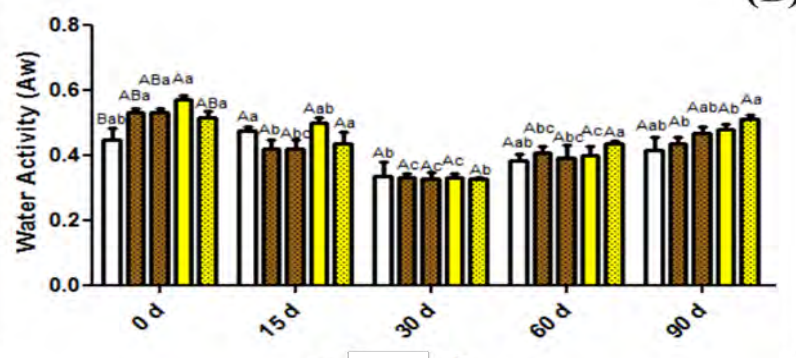

(D)

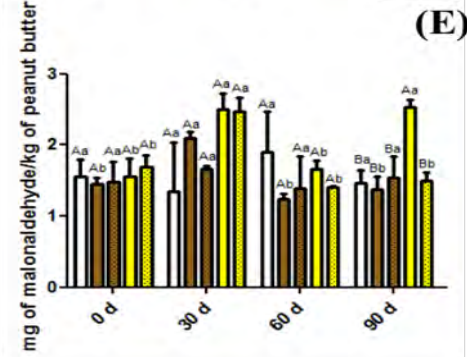

Bars identified by the same upper letters of the same time interval are not statistically different. Bars identified by the same lower letters in the same treatments are not statistically different ( $p>0.05)$. 
Formulations containing free probiotic presented a reduction of $\mathrm{A}_{\mathrm{w}}$ after 90 days of storage, probably there was a balance between the humidity of the environment and the product after opening (Figure 16 B). Also, the application of freeze-dried microcapsules did not modify significantly this parameter. Thus, the final values of $\mathrm{A}_{\mathrm{w}}$ ranged from 0.40 to 0.46 approximately. Low $\mathrm{A}_{\mathrm{w}}$ food products are known for preventing the proliferation of microorganisms, but they could increase the oxidation reactions, which is harmful to the lipid matrix. In this way, the oxidative stability of peanut butter formulations was evaluated.

The color of the peanut butter formulations is essential for a good appearance, increasing its attractivity and acceptance by consumers. In this way, the total color difference $(\Delta \mathrm{E})$ during the storage of peanut butter was calculated, considering the color parameters of peanut butter formulations at 0 and 90 days of storage. Thus, values of $1.52 \pm 0.14,1.43 \pm 0.23,0.93 \pm 0.02$, $1.55 \pm 0.29,1.30 \pm 0.08$ were calculated for control, PBF, PBE, PBGF and PBGE, respectively. Peanut butter containing only probiotic encapsulated (PBE) showed the lowest $\Delta \mathrm{E}$ value, demonstrating that application of freeze-dried microcapsules did not interfere significantly in color change of peanut butter, maintaining its regular appearance. Although $\Delta \mathrm{E}$ values of the other formulations differed statistically ( $p>0.05$ ), the color change was slight during storage.

\subsubsection{Phenolics, $\alpha$-tocopherol and oxidation by TBARS}

Peanut butter contains phenolic compounds and tocopherols, which present known antioxidant capacity. Thus, the total phenolic content (TPC) and tocopherols for all peanut butter formulations were evaluated. Figure $16 \mathrm{C}$ illustrates that TPC varied from 1.3 to $1.7 \mathrm{mg}$ GAE/g of peanut butter. PBF and PBGF showed a slightly higher TPC at the end of storage, around $1.7 \mathrm{mg}$ GAE/g of peanut butter, differing statistically from control formulations. The incorporation of probiotic inoculum, which contains proteins in the cell wall, could interfere with quantifying phenolic compounds using the Folin-Ciocalteu reagent.

Ma et al. (2014) developed a fortified peanut butter with peanut skin, increasing at least 2fold of TPC, depending on the concentration of skin added to the formulations. However, another study reported an inhibitory effect of peanut skin extract against probiotics (PENG; BITSKO; 
BISWAS, 2015). For this reason, the unskinned peanut was used to produce peanut butter in this study spite of peanut skin could contribute to phenolic compounds.

Concerning the tocopherols, only $\alpha$-tocopherol was found in these formulations, varying from 7 to $10.8 \mathrm{mg} / 100 \mathrm{~g}$ of peanut butter (Figure 16 D). The application of sunflower oil to protect the carotenoids from guaraná peels during the extraction did not increase the tocopherol content in PBGF and PBGE formulations. Besides that, the peanuts roasting and grinding processes apply high temperature, which could reduce the final tocopherol content of peanut butter and degrading other fractions. Control, PBE, PBGF and PBGE showed maintenance of $\alpha$-tocopherol content during the storage. In contrast, the $\alpha$-tocopherol content showed a small reduction for PBF after 90 days of storage, which could be correlated with its oxidation to protect free probiotic. This protective effect of tocopherol was investigated before by Ying et al. (2011), who verified that coencapsulation of probiotic and tocopherol increased the probiotic viability due to the antioxidant effect in membrane lipids.

Another study evaluated the microwave pre-treatment to produce peanut butter, reporting the presence of other fractions of tocopherols and total tocopherols varied from 11.30 to 19.05 $\mathrm{mg} / 100 \mathrm{~g}$ of peanut butter (DEGON et al., 2021). Thus, in addition to thermal processes applied, the presence of some tocopherol fractions may differ with the variety of peanuts.

Oil oxidation is the main factor that limits the shelf life of peanut butter, even with the presence of potent antioxidants in its formulations. Among the formulations, PBGF showed the highest production of malonaldehyde, approximately $2.5 \mathrm{mg} / 100 \mathrm{~g}$ of peanut butter (Figure $16 \mathrm{E}$ ). In contrast, the other formulations maintained the content of malonaldehyde during the storage, indicating a low oxidation rate. In this way, the application of unencapsulated GPE in peanut butter displayed a higher oxidation rate, which refers to an oxidized product probably causing consumers' rejection after 90 days of storage. Besides that, the application of encapsulated GPE may cause the gradual release of carotenoids, which could slow up the oxidation of peanut butter due to the presence of antioxidants.

Similar values were reported by El-Rawas et al. (2012), who evaluated electron beam irradiation in peanut butter to control the proliferation of Salmonella. These authors verified that 
control formulation showed a malonaldehyde content from 0.98 to $1.61 \mathrm{mg} / \mathrm{kg}$ of sample between the period of 2 and 14 days, respectively.

\subsubsection{Texture parameters}

Table 10 displays the texture parameters evaluated on the first and last day of storage of these products. Concerning the control formulation, texture parameters were maintained at $25^{\circ} \mathrm{C}$ up to 90 days. On the other hand, applying probiotic inoculum in peanut butter, which refers to formulation PBF, reduced the initial firmness, adhesion and work penetration. However, after 90 days of storage, these parameters did not differ from control peanut butter, except the adhesiveness, which decreased. PBGF displayed a reduction of the same texture parameters initially, but these values differed from the final parameters of the control formulation. In this way, unencapsulated GPE changed the texture quality of peanut butter over the storage.

Similarly, the supplementation of co-encapsulated probiotic with GPE affected the firmness, adhesion, and penetration work at the beginning and end of the storage. The soft firmness of PBGE suggests that GPE may be released from the microcapsules during the storage of peanut butter. In contrast, peanut butter containing only encapsulated probiotic showed a reduction of firmness and adhesion initially, reaching similar values to the control at the end of storage.

Another study reported that peanut butter supplemented with freeze-dried hydroxypropyl methylcellulose and methylcellulose increased firmness (TANTI et al., 2016). Although the microcapsules were freeze-dried for application in peanut butter, the concentration of gelatin and Arabic gum did not affect the texture quality of formulations. Thus, the application of microcapsules did not significantly affect the texture parameters, considering that the texture of the peanut butter is important for product acceptance. 
Table 10 - Texture parameters of peanut butter formulations at the beginning of storage and after 90 days at $25^{\circ} \mathrm{C}$.

\begin{tabular}{|c|c|c|c|c|c|c|c|c|}
\hline \multirow{2}{*}{ Formulations } & \multicolumn{2}{|c|}{ Firmness (N) } & \multicolumn{2}{|c|}{ Adhesion (N) } & \multicolumn{2}{|c|}{ Work of penetration $\left(\mathrm{N}^{*} \mathrm{~s}\right)$} & \multicolumn{2}{|c|}{ Adhesiveness $(\mathrm{N} * \mathrm{~s})$} \\
\hline & $0 \mathrm{~d}$ & $90 \mathrm{~d}$ & $0 \mathrm{~d}$ & $90 \mathrm{~d}$ & $0 \mathrm{~d}$ & $90 \mathrm{~d}$ & $0 \mathrm{~d}$ & $90 \mathrm{~d}$ \\
\hline Control & $1.14 \pm 0.06^{\mathrm{Aa}}$ & $1.14 \pm 0.12^{\mathrm{Aa}}$ & $0.74 \pm 0.08^{\mathrm{Aa}}$ & $0.73 \pm 0.04^{\mathrm{Aa}}$ & $5.19 \pm 0.34^{\mathrm{Aa}}$ & $5.23 \pm 0.44^{\mathrm{Aa}}$ & $1.26 \pm 0.22^{\mathrm{Aa}}$ & $1.22 \pm 0.14^{\mathrm{Aa}}$ \\
\hline $\mathrm{PBF}$ & $0.88 \pm 0.01^{\mathrm{Db}}$ & $1.11 \pm 0.05^{\mathrm{Aa}}$ & $0.59 \pm 0.02^{\mathrm{Cb}}$ & $0.71 \pm 0.04^{\mathrm{Aa}}$ & $4.09 \pm 0.12^{\mathrm{Bb}}$ & $5.02 \pm 0.20^{\mathrm{Aa}}$ & $1.30 \pm 0.07^{\mathrm{Aa}}$ & $1.14 \pm 0.05^{\mathrm{Ab}}$ \\
\hline PBE & $1.07 \pm 0.03^{\mathrm{Ba}}$ & $1.14 \pm 0.07^{\mathrm{Aa}}$ & $0.70 \pm 0.05^{\mathrm{Ba}}$ & $0.71 \pm 0.03^{\mathrm{Aa}}$ & $4.97 \pm 0.21^{\mathrm{Aa}}$ & $5.22 \pm 0.27^{\mathrm{Aa}}$ & $1.05 \pm 0.11^{\mathrm{Ab}}$ & $1.24 \pm 0.08^{\mathrm{Aa}}$ \\
\hline PBGF & $0.96 \pm 0.03^{\mathrm{Ca}}$ & $0.96 \pm 0.03^{\mathrm{Ba}}$ & $0.65 \pm 0.03^{\mathrm{ABa}}$ & $0.57 \pm 0.04^{\mathrm{Cb}}$ & $4.36 \pm 0.17^{\mathrm{Ba}}$ & $4.39 \pm 0.07^{\mathrm{Ba}}$ & $1.15 \pm 0.14^{\mathrm{Aa}}$ & $1.16 \pm 0.07^{\mathrm{Aa}}$ \\
\hline PBGE & $0.92 \pm 0.02^{\mathrm{CDa}}$ & $0.95 \pm 0.03^{\mathrm{Ba}}$ & $0.60 \pm 0.03^{\mathrm{Ba}}$ & $0.64 \pm 0.03^{\mathrm{Ba}}$ & $4.27 \pm 0.06^{\mathrm{Ba}}$ & $4.39 \pm 0.17^{\mathrm{Ba}}$ & $1.19 \pm 0.10^{\mathrm{Aa}}$ & $1.03 \pm 0.25^{\mathrm{Aa}}$ \\
\hline
\end{tabular}

Values with the same upper-case letter in a column and the same lower-case letter in a row for the same texture parameter are not statistically different ( $p>0.05)$. In this table, control is the regular peanut butter formulation, PBF is the peanut butter containing free probiotic, PBE is the peanut butter containing encapsulated probiotic, PBGF is the peanut butter containing free probiotic and guaraná peel extract, and PBGE is the peanut butter containing co-encapsulated probiotic and guaraná peel extract. 


\subsubsection{Viability of probiotic in peanut butter}

The viability of probiotic added to the peanut butter formulations was evaluated during the storage at $25^{\circ} \mathrm{C}$ for 90 days, as showed in Figure $16 \mathrm{~F}$. The initial counts of probiotic were around $8 \log$ CFU/g of peanut butter. At the end of storage, free probiotic population added to the peanut butter $(\mathrm{PBF})$ showed a reduction of $3 \mathrm{log} \mathrm{CFU} / \mathrm{g}$. In contrast, PBE containing encapsulated probiotic showed a decrease around $0.5 \log \mathrm{CFU} / \mathrm{g}$ after 90 days, while the counts for probiotic added to PBGF and PBGE were maintained higher than $7 \log \mathrm{CFU} / \mathrm{g}$. In this way, the microencapsulation by complex coacervation improved the survivability of probiotic in peanut butter. These findings are in accordance with other than reported the encapsulation supported the viability of probiotic in sugarcane juice (HOLKEM et al., 2020).

Another study reported a decrease of unencapsulated probiotic viability in peanut butter stored at $25^{\circ} \mathrm{C}$ for 12 months, varying between 1 to $3 \log \mathrm{CFU} / \mathrm{g}$, depending on the probiotic strain (KLU; PHILLIPS; CHEN, 2014). Also, these authors verified that Bifidobacterium strains showed higher viability. Although peanut butter protects some probiotic strains, microencapsulation is a different approach to enhance the survivability of some probiotic strains during the storage of peanut butter.

In addition, the combination of free probiotic cells and GPE also improved the probiotic viability, which could be related to the chemical composition of this extract. The antioxidant capacity of carotenoids may reduce oxidative stress, one of the leading causes of probiotic death. For example, Borgonovi, Casarotti and Penna (2021) verified the positive influence of buriti pulp added to the milk fermented with Lacticaseibacillus casei SJR38, correlating these findings with the bioactive compounds, such as phenolic compounds and carotenoids. Similarly, Silva et al. (Reviewing) verified that MRS broth supplemented with GPE enhanced the growth of probiotic cells during the incubation.

\subsubsection{Sensory evaluation: panelists' profile, acceptance test and purchase intention}

Figure 17 illustrates the panelists' profile (A, B, C), the sensory attributes (D) and purchase intention (E) of peanut butter formulations. Concerning the untrained panelists, around $78 \%$ were 
from 17 to 25 years and $47 \%$ preferred sugar-free peanut butter. However, all panelists were willing to consume functional peanut butter.

The application of microcapsules in peanut butter did not affect the sensory attributes, as shown in Figure 17 D. The texture and spreadability of peanut butter could be changed after adding freeze-dried microcapsules, but all formulations displayed a score of around 7.5, confirming the instrumental texture assay. However, free GPE significantly influenced the aroma and taste of peanut butter, hindering consumers' acceptance of this product. Microencapsulation masked the smell and taste of GPE since all the sensory parameters did not differ significantly from the control formulation. Also, these results were corroborated with other studies that incorporated microcapsules loaded with plant extracts and probiotic in food matrices, reporting that free extracts reduced the overall acceptability of the products (HOLKEM et al., 2020; SILVA et al., 2022).

In addition, purchase intentions of formulations were around 60\%,69\%, 65\% 35\% and $63 \%$ for the control, PBF, PBE, PBGF and PBGE formulations, respectively. It is relevant to stand out that the purchase intention of peanut butter formulations could be higher if all panelists preferred no-sugar peanut butter formulations. Also, these results can be related to the relevant aspects of the panelists' purchase decision (Figure $17 \mathrm{C}$ ). Approximately $28 \%$ of panelists cited the price, $20 \%$ taste, $18 \%$ texture, and $13 \%$ quality. Other aspects described were brand, gym, convenience, organic, packing, additional ingredients and benefits. Thus, the lowest score to the taste of PBGF impacted the lowest purchase intention of the same formulation. Hence, encapsulation allows loading GPE without change the sensory quality of the peanut butter, obtaining similar purchase intention with control formulation. 
Figure 17 - Panelist's profile regards the age group (A), consumption preference of peanut butter formulation (B) and the relevant aspects for purchase decision of peanut butter (C). The sensory attributes scores (D) and purchase intention (E) for control peanut butter, peanut butter containing free probiotic $(\mathrm{PBF})$, peanut butter containing encapsulated probiotic (PBE), peanut butter containing free probiotic and guaraná peel extract (PBGF) and peanut butter containing co-encapsulated probiotic and guaraná peel extract (PBGE).

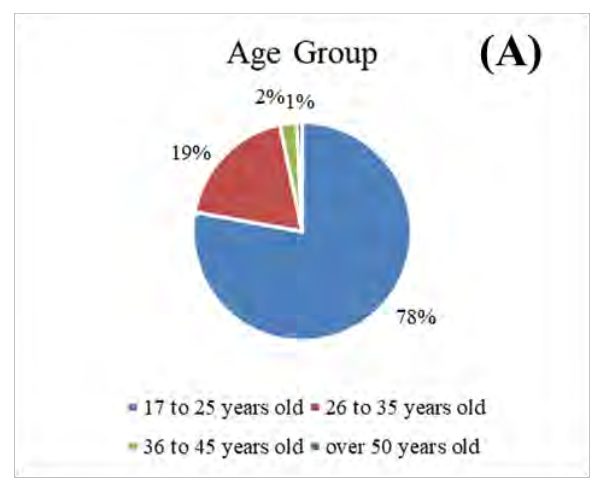

Sensory Attributes

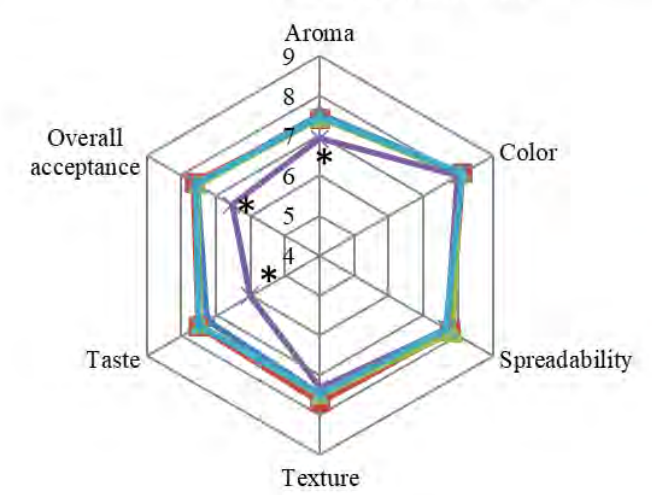

Preference of peanut butter formulation

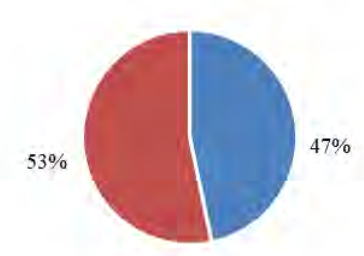

- No added sugar - Sweetened
(B)

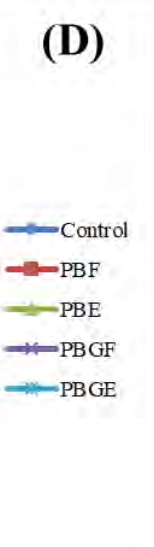

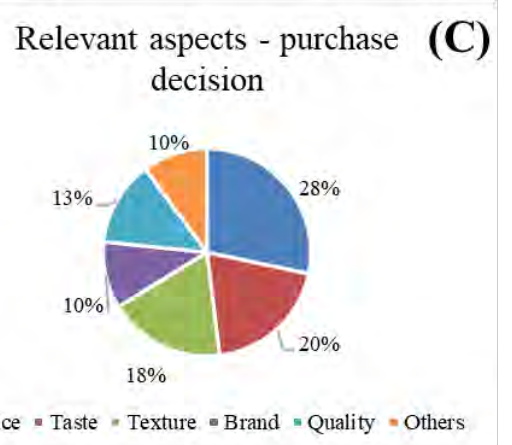

(E)

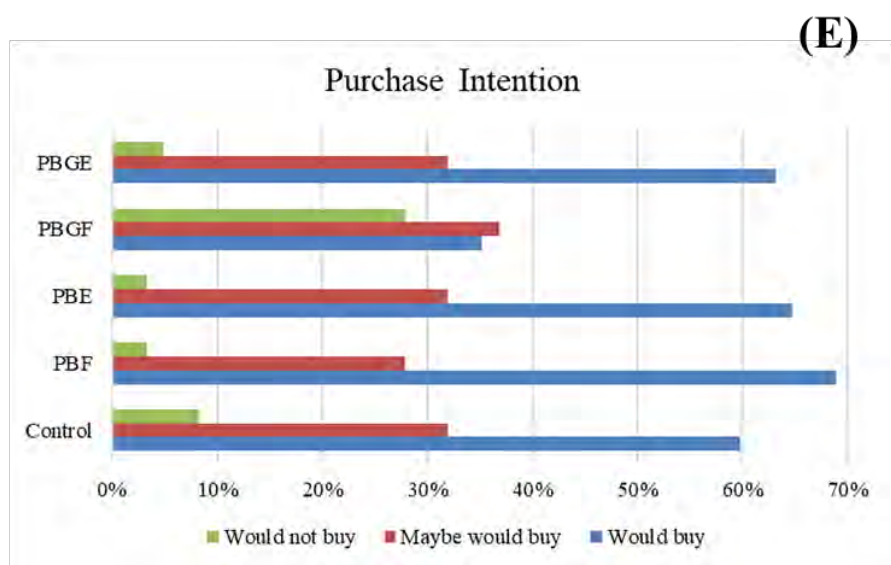

Sensory attributes scores with an asterisk are statistically different ( $p>0.05)$. 


\subsection{CONCLUSIONS}

Production of carotenoid-rich GPE can be a sustainable alternative to valorize this agroindustrial waste. Co-encapsulation by complex coacervation enhanced the protection of carotenoids, comparing to the free GPE stored at $25^{\circ} \mathrm{C}$. Also, the simultaneous encapsulation of B. animalis subsp. lactis BLC-1 and GPE improved the probiotic viability, reaching counts above the recommended daily dose. In addition, the incorporation of freeze-dried microcapsules to peanut butter maintained the quality parameters and improved the probiotic viability during storage. Additionally, GPE increased the viability of probiotic added in peanut butter, but its application in free form reduced the sensory acceptability by the low scores for taste and aroma attributes. However, microencapsulation masked the bitter taste of GPE, achieving good sensory scores. Overall, the results of this study display a novel association of functional ingredients produced by complex coacervation for the fortification of peanut butter, obtaining standardized products well-accepted by panelists.

\section{ACKNOWLEDGEMENTS}

Authors thanks the Coordenação de Aperfeiçoamento de Pessoal de Nível Superior - Brazil (CAPES) - Finance Code 001 and São Paulo Research Foundation (FAPESP) for the fellowship awarded to Marluci Palazzolli da Silva (grant number \#2016/24895-5 and grant number \#2019/09757-3). Favaro-Trindade also thanks Conselho Nacional de Desenvolvimento Científico e Tecnológico (CNPq) for the productivity grant (Process \#305115/2018-9).

\section{REFERENCES}

AHMED, E. M.; ALI, T. Textural quality of peanut butter as influenced by peanut seed and oil contents. Peanut Science, v. 13, p. 18-20, 1986.

ALAÑÓN, M. E. et al. Assessment of flavanol stereoisomers and caffeine and theobromine content in commercial chocolates. Food Chemistry, v. 208, p. 177-184, 2016. 
AL-OKBI, S. Y. et al. Role of Bifidobacterium bifidum and plant food extracts in improving microflora and biochemical and cytogenetic parameters in adjuvant arthritis. Grasas y Aceites, v. 62, p. 308-320, 2011.

Association of Official Analytical Chemists (AOAC) (2005), Official Methods of Analysis, $16^{\text {th }}$ ed., AOAC, Arlington, TX.

BORGONOVI, T. F.; CASAROTTI, S. N.; PENNA, A. L. B. Lacticaseibacillus casei SJRP38 and buriti pulp increased bioactive compounds and probiotic potential of fermented milk. LWT Food Science and Technology, v. 143, 111124, 2021.

CHUNG, H. J. et al. Metabolic and Lipidomic Profiling of Vegetable Juices Fermented with Various Probiotics. Biomolecules, v. 10, 725, 2020.

CHUYEN, H. V. et al. Encapsulation of carotenoid-rich oil from Gac peel: Optimisation of the encapsulating process using a spray drier and the storage stability of encapsulated powder.

Powder Technology, v. 344, p. 373-379, 2019.

CITERNE, G.; CARREAU, P.; MOAN, M. Rheological properties of peanut butter. Rheologica Acta, v. 40, p. 86-96, 2001.

COMUNIAN, T. A. et al. Development of functional yogurt containing free and encapsulated echium oil, phytosterol and sinapic acid. Food Chemistry, v. 237, p. 948-956, 2017.

DEGON, J. G. et al. Effect of microwave pre-treatment on physical quality, bioactive compounds, safety risk factor, and storage stability of peanut butter. Oil Crop Science, v. 6, p. 134-144, 2021.

EL-RAWAS, A. et al. Effect of electron beam irradiation on quality indicators of peanut butter over a storage period. Food Chemistry, v. 133, p. 212-219, 2012. 
GOMEZ-ESTACA, J. et al. Encapsulation of an astaxanthin-containing lipid extract from shrimp waste by complex coacervation using a novel gelatin-cashew gum complex. Food

Hydrocolloids, v. 61, p. 155-162, 2016.

GONG, A. et al. Relationship of chemical properties of different peanut varieties to peanut butter storage stability. Journal of Integrative Agriculture, v. 17, p. 1003-1010, 2018.

HOLKEM, A. T. et al. (2020). Sugarcane Juice with Co-encapsulated Bifidobacterium animalis subsp. lactis BLC1 and Proanthocyanidin-Rich Cinnamon Extract. Probiotics and Antimicrobial Proteins, v. 12, p. 1179-1192, 2020.

HOLKEM, A. T.; FAVARO-TRINDADE, C. S. Potential of solid lipid microparticles covered by the protein-polysaccharide complex for protection of probiotics and proanthocyanidin-rich cinnamon extract. Food Research International, v. 136, 109520, 2020.

KLU, Y. A. K.; PHILLIPS, R. D.; CHEN, J. Survival of four commercial probiotic mixtures in full fat and reduced fat peanut butter. Food Microbiology, v. 44, p. 34-40, 2014.

KRINSKY, N. I.; JOHNSON, E. J. Carotenoid actions and their relation to health and disease. Molecular Aspects of Medicine, v. 26, p. 459-516, 2005.

MA, Y. et al. Peanut skins fortified peanut butters: Effect of processing on the phenolics content, fibre content and antioxidant activity. Food Chemistry, v. 145, p. 883-891, 2014.

MEILGAARD, M.; CIVILLE, G. V.; CARR, B. T. Sensory evaluation techniques. 3rd ed. Boca Raton: CRC Press, 1999. 390 p.

OIKONOMOPOULOU, V. P.; KROKIDA, M. K.; KARATHANOS, V. T. The influence of freeze drying conditions on microstructural changes of food products. Procedia Food Science, v. 1, p. 647-654, 2011. 
PINHO, L. S. et al. Guaraná (Paullinia cupana) by-product as a source of bioactive compounds and as a natural antioxidant for food applications. Journal of Processing and Preservation, v. 45, 2021.

RODRIGUEZ-AMAYA, D. B. Update on natural food pigments - A mini-review on carotenoids, anthocyanins, and betalains. Food Research International, v. 124, p. 200-205, 2019.

RODRIGUEZ-AMAYA, D. B.; KIMURA, M. (2004). HarvestPlus Handbook for Carotenoid Analysis. (HarvestPlus Technical Monograph 2). Washington, DC: HarvestPlus, 2004.

SANTOS, C. S. et al. Effect of enzymatic interesterification on the textural and nutritional properties of a probiotic table spread containing milk fat. LWT - Food Science and Technology, v. 124, 109129, 2020.

SANTOS, P. D. F. et al. (2021a). Microencapsulation of carotenoid-rich materials: A review. Food Research International, v. 147, 110571, 2021a.

SANTOS, P. D. F. et al. Application of spray drying for production of microparticles containing the carotenoid rich tucumã oil (Astrocaryum vulgare Mart.). LWT - Food Science and Technology, v. 143, 111106, $2021 b$.

SHARIFI, S. et al. Use of whey protein isolate and gum Arabic for the co-encapsulation of probiotic Lactobacillus plantarum and phytosterols by complex coacervation: Enhanced viability of probiotic in Iranian white cheese. Food Hydrocolloids, v. 113, 106496, 2021.

SILVA, M. P. et al. Fortification of yoghurt drink with microcapsules loaded with Lacticaseibacillus paracasei BGP1 and guaraná seed extract. International Dairy Journal, v.125, 105230, 2022.

SILVA, M. P. et al. (Reviewing). Co-encapsulation of guaraná extracts and probiotics increases probiotic survivability and simultaneously delivers bioactive compounds in simulated gastrointestinal fluids. LWT - Food Science and Technology. 
SILVA, M. P. et al. Application of spray chilling and electrostatic interaction to produce lipid microparticles loaded with probiotics as an alternative to improve resistance under stress conditions. Food Hydrocolloids, v. 83, p. 109-117, 2018.

SILVA, M.P. et al. Semisweet chocolate as a vehicle for the probiotics Lactobacillus acidophilus LA3 and Bifidobacterium animalis subsp lactis BLC1: Evaluation of chocolate stability and probiotic survival under in vitro simulated gastrointestinal conditions. LWT - Food Science and Technology, v. 75, p. 640-647, 2017.

SINGLETON, V. L.; ORTHOFER, R.; LAMUELA-RAVENTOS, R. M. Analysis of total phenols and other oxidation substrates and antioxidants by means of Folin-ciocalteu reagent. Methods of Enzymology, v. 299, p. 152-178, 1999.

TANTI, R.; BARBUT, S.; MARANGONI, A. G. Oil stabilization of natural peanut butter using food grade polymers. Food Hydrocolloids, v. 61, p. 399-408, 2016.

TULINI, F. L. et al. Evaluation of the release profile, stability and antioxidant activity of a proanthocyanidin-rich cinnamon (Cinnamomum zeylanicum) extract co-encapsulated with $\alpha$ tocopherol by spray chilling. Food Research International, v. 95, p. 117-124, 2017.

VYNCKE, W. Direct determination of the thiobarbituric acid value in thricloracetic acid extracts of fish as a measure of oxidative rancidity. European Journal of Lipid Science and Technology, v. 72, p. 1084-1087, 1970.

XU, Y. et al. Fermentation by Probiotic Lactobacillus gasseri Strains Enhances the Carotenoid and Fibre Contents of Carrot Juice. Foods, v. 9, 1803, 2020.

YING, D. et al. Tocopherol and Ascorbate Have Contrasting Effects on the Viability of Microencapsulated Lactobacillus rhamnosus GG. Journal of Agricultural and Food Chemistry, v. 59, p. 10556-10563, 2011. 
6 CHAPTER 5 - VACUUM-ASSISTED BIOSORPTION AS A PROMISING APPROACH FOR SIMULTANEOUS DELIVERY OF LIVE PROBIOTICS AND PLANT-PHENOLIC COMPOUNDS 


\title{
6 CHAPTER 5 - VACUUM-ASSISTED BIOSORPTION AS A PROMISING APPROACH FOR SIMULTANEOUS DELIVERY OF LIVE PROBIOTICS AND PLANT-PHENOLIC COMPOUNDS
}

\begin{abstract}
This study focused on the biosorption of phenolic-rich plant extracts produced using jabuticaba peel and guaraná seed in three probiotic strains by vacuum and passive mechanisms. Besides that, catechin solution was used to verify if the complex composition of plant extracts could affect biosorption. Vacuum biosorption using jabuticaba peel in $25 \%$ of ethanol solution (JP25\%) provided the maximum loading of phenolic compounds (PC), around $9 \mathrm{mg}$ Gallic Acid Equivalent (GAE)/g of cells in less than 5 minutes without significantly influencing cell viability. In contrast, the total phenolic content of probiotic cells loaded with guaraná seed extract (GSE) and catechin solution was between 3.5 to $5 \mathrm{mg} \mathrm{GAE} / \mathrm{g}$ of cells. In this way, the vacuum mechanism provided around 2-4 fold high loading of PC than that obtained via passive. Vacuum biosorption in probiotic cells was confirmed by multiphotonic microscopy. The viability of freeze-dried cells loaded with plant extracts by vacuum was between 5.8 to $10.5 \log \mathrm{CFU} / \mathrm{g}$ stored at $25{ }^{\circ} \mathrm{C}$ up to 30 days. Furthermore, PC release from Lacticaseibacillus cells was from $55 \%$ to $75 \%$ of PC in simulated gastrointestinal fluids. This research provides a novel platform to deliver probiotics and PC in the gut.
\end{abstract}

Keywords: biosorption, jabuticaba, guaraná, phenolic compounds, Lacticaseibacillus, release. 


\subsection{INTRODUCTION}

The consumption of rich-polyphenols foods provides several health benefits due to their anti-inflammatory properties, improving insulin resistance, type 2 diabetes and oxidative stress (GUASCH-FERRÉ et al., 2017). Various sources of PC are included in our diet, such as fruits, vegetables, olives, tea leaves, cocoa, red wine, etc. However, a sustainable trend is to recover PC from some parts of plants, such as seeds and peels, discarded during processing. In addition, the intake dose and the variety of polyphenols enhance the colonization of Lactobacillus and Bifidobacterium species, known as probiotics, reducing the proliferation of pathogenic species in the gut (MA and CHEN, 2020). Besides that, gut microbiota enhances the bioaccessibility of polyphenols, indicating their positive interplay (VALDÉS et al., 2015).

Several carriers are explored to protect PC from harmful conditions, using starch (SHI et al., 2021), gelatin and other polysaccharides (SOUZA et al., 2018), vegetable fat (SILVA et al., 2019), inulin/fructooligosaccharides/pectin (TARONE et al., 2021), etc. In this way, the investigation of other carriers to preserve the polyphenols, improving their bioavailability to get the health benefits is indispensable. Cell-based carriers are promising natural structures, which may promote the protection of bioactive compounds. The application of cells as carriers has some biotechnological advantages due to the desired cell wall composition that allows the entrapment of diverse bioactive compounds. In addition, the production of cells can be easy to scale up, standing out the reuse of cells by-products from brewing and winery industries. However, most cell-based carriers explored to deliver bioactive compounds are inactivated cells and cells from yeast/fungal strains (YOUNG et al., 2017; RUBIO et al., 2020).

In this context, the use of live probiotics cells increases the options of matrices for biosorption with the status "generally recognized as safe" (GRAS). Another advantage is the simultaneous delivery of live probiotics and polyphenols in the gut, which may promote several health benefits by this combination, such as improving the bioavailability of polyphenols and the probiotic colonization in the gut. In addition, the small size of probiotic cells is beneficial for application in food or as a supplement.

Some critical parameters to perform the biosorption of PC in cells-based carriers are the permeability, hydrophobicity and composition of the cell wall. Besides that, understanding the 
physicochemical properties of bioactive compounds is relevant to predicting their affinity with the cell. In this way, some studies proposed the plasmolysis, ultrasound, organic solvents, enzyme, heat and basis treatments to improve the diffusion of materials into yeast cells (PARAMERA et al., 2011a; PHAM-HOANG et al., 2016; PHAM-HOANG et al., 2018; YOUNG et al., 2017). However, probiotics are sensitive to these harsh conditions, affecting their functionality. To solve this problem, another approach like vacuum is an alternative for improving the biosorption of bioactive compounds in cells and maintaining probiotic cells' viability. Recently, curcumin and fisetin were successfully encapsulated in yeast cells using vacuum, which is a fast, non-thermal and effective process compared with passive mechanism (YOUNG et al., 2017). Another study evaluated that vacuum infusion effectively encapsulated trans-resveratrol in grape skin powder (RAI et al., 2021).

In this way, we have selected Lacticaseibacillus strains for biosorption of phenolic-rich plant extracts due to the potential probiotic status. Concerning the plants used to recover the PC, jabuticaba (Myrciaria cauliflora) peels and guaraná (Paullinia cupana) seeds were explored due to the presence of anthocyanins and catechins, respectively, beyond their potential health benefits. Figure 18 displays the schematic representation of the present study. The overall goals of this study were (i) to produce jabuticaba peel extracts and guaraná seed extract (GSE) following by the biosorption in live probiotic cells, comparing the vacuum and passive mechanisms; (ii) to verify if a standard catechin solution enhances the loading of PC in probiotic cells, correlating with the plant extracts; (iii) to assess the release of PC in simulated gastrointestinal fluids; (iv) to evaluate the viability of freeze-dried probiotics loaded with PC from plant extracts during the storage. Thus, this study addresses a promising technology for the simultaneous delivery of live probiotic cells and phenolic compounds in the gut, which is desirable for health benefits.

\subsection{MATERIAL AND METHODS}

\subsubsection{Materials}

Three probiotic strains were used as carrier: Lacticaseibacillus casei ATCC 393, L. paracasei BGP-1 (Sacco, Brazil) and L. rhamnosus GG. Jabuticaba peel and guaraná seed were kindly donated by Ricaeli (Cabreuva, Sao Paulo, Brazil) and Executive Commission of the Rural 
Economic Recuperation Plan in Cacao (Taperoá, Bahia, Brazil), respectively. (+)-Catechin (hydrate) standard was purchased from Cayman Chemical Company.

Figure 18 - Schematic representation of the present study.

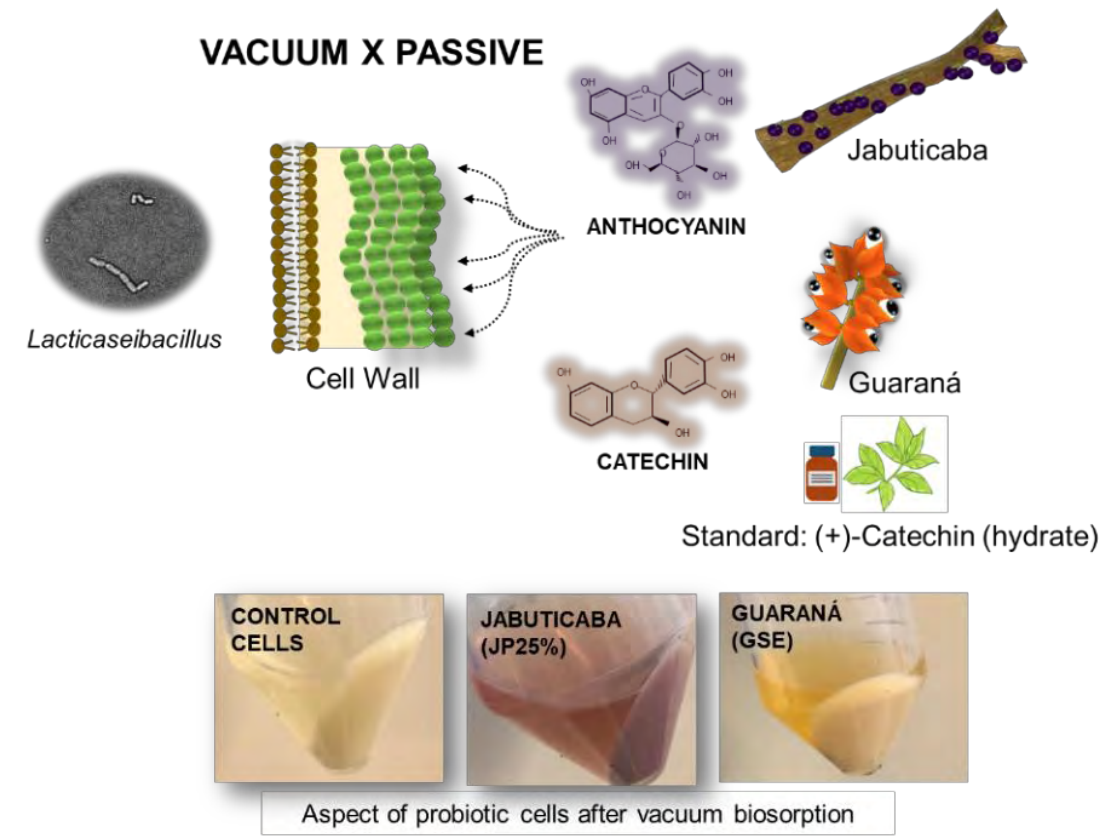

Reference: Own source.

\subsubsection{Methods}

\subsubsection{Production of phenolic-rich jabuticaba peel and guaraná seed (GSE) extracts}

Previously, jabuticaba peel and guaraná seed were washed and dried at $50{ }^{\circ} \mathrm{C}$ for $24 \mathrm{~h}$ to avoid spoilage. Then, the dried jabuticaba peel and guaraná seed were kept at $-18^{\circ} \mathrm{C}$ for sequential experiments.

First, dried jabuticaba peel was crushed by blender, obtaining particles size below $0.1 \mathrm{~mm}$. Extraction of PC from jabuticaba peel was performed using the proportion 1:25 (jabuticaba peel:solvent) at $40{ }^{\circ} \mathrm{C}$ and $200 \mathrm{rpm}$. Pure water, $25 \%(\mathrm{v} / \mathrm{v})$ ethanol and $50 \%(\mathrm{v} / \mathrm{v})$ ethanol solutions were applied to recover PC and designated as JPW, JP25\% and JP50\%, respectively. Aliquots were withdrawn during extraction ( $\mathrm{t}=2 \mathrm{~h}, 4 \mathrm{~h}$ and $6 \mathrm{~h}$ ) to evaluate the total phenolic content (TPC). Then, the best extraction time was selected considering the extract with the highest level of PC. 
In contrast, parameters for PC extraction from guaraná seed were previously studied by Silva et al. (2019). GSE was produced using 50\% (v/v) ethanol solution and mechanical stirring at $60^{\circ} \mathrm{C}$ for $30 \mathrm{~min}$. The proportion of crushed dried guaraná seed and solvent was 1:20 (w/w). GSE was atomized in an MSD 1.0 spray dryer (LabMaq, Brazil) at $150{ }^{\circ} \mathrm{C}$ with a 1.2 nozzle and 10 $\mathrm{mL} / \mathrm{min}$ of feed flow. Dried GSE in powder form was stored at $-18^{\circ} \mathrm{C}$ until its application.

\subsubsection{Total phenolic content (TPC)}

TPC was determined accordingly to Waterhouse (2002) with some modifications. In this way, $20 \mu \mathrm{l}$ of the sample, $1.58 \mathrm{~mL}$ of water and $100 \mu 1$ of Folin-Ciocalteu reagent were added to the cuvette. After $3 \mathrm{~min}, 300 \mu \mathrm{l}$ of saturated sodium carbonate was added to the cuvette and mixed. Cuvettes were kept at room temperature and protected from the light for $45 \mathrm{~min}$. Absorbance was reading at $750 \mathrm{~nm}$ by spectrophotometry (GENESYS 10S Series, Thermo Scientific). TPC was expressed as $\mathrm{mg} \mathrm{GAE} / \mathrm{g}$ of sample.

\subsubsection{Activation of probiotic cells for encapsulation}

Probiotic cells were activated in $10 \mathrm{~mL}$ of De Man, Rogosa and Sharpe - MRS broth and incubated at $37^{\circ} \mathrm{C}$ for $18 \mathrm{~h}$. Sequentially, the inoculum was added to $100 \mathrm{~mL}$ of MRS broth and incubated again. Then, cells were separated by centrifugation at 7,000 rpm for $5 \mathrm{~min}$ followed by washing with phosphate-buffered saline - PBS buffer twice. Finally, the pellet was set apart for the later addition of stock solutions for biosorption.

6.2.2.4 Biosorption of jabuticaba extracts (JPW, JP25\% and JP50\%) in probiotic cells: influence of ethanol concentration during vacuum and passive mechanisms

The effect of different concentrations of ethanol was evaluated during the application of vacuum and passive biosorption. First, the stock solutions were produced as described in section 6.2.2.1 and sequentially used for biosorption. For this, the mass ratio of cell pellet and jabuticaba extracts (JPW, JP25\% and JP50\%) was $1 \mathrm{~g}$ for $5 \mathrm{~mL}$ of stock solutions, as Young et al. (2017) 
proposed. Then, the cell pellet was mixed with jabuticaba extracts using a vortex for 1 min, followed by applying passive or vacuum mechanisms.

Vacuum biosorption was performed using a packaging machine (Ultravac 250, Koch, USA) under conditions at $99 \%$ of vacuum for $5 \mathrm{~s}$. Regarding the passive biosorption, samples were kept under agitation at $7^{\circ} \mathrm{C}$ for $24 \mathrm{~h}$. This temperature was selected to maintain the viability of probiotic cells.

\subsubsection{Biosorption of catechin solution and GSE in probiotic cells by vacuum and passive mechanisms: effect of polyphenols}

Catechin solution was prepared at concentration $4 \mathrm{mg} / \mathrm{mL}$ in $25 \%(\mathrm{v} / \mathrm{v})$ ethanol, while spray-dried GSE was rehydrated at concentration $7.5 \mathrm{mg} / \mathrm{mL}$ in $25 \%$ (v/v) ethanol, followed by homogenization. These concentrations were selected due to the solubility of powders, avoiding precipitation.

Similarly, $5 \mathrm{~mL}$ of each stock solutions were added in $1 \mathrm{~g}$ of probiotic pellet. Finally, as blank to avoid any interference of probiotic cells during the quantification of PC by FolinCiocalteu reagent, $1 \mathrm{~g}$ of cells were added in $5 \mathrm{~mL}$ of $25 \%(\mathrm{v} / \mathrm{v})$ ethanol.

Lastly, samples with stock solutions were mixed to apply vacuum and passive mechanisms as described in section 6.2.2.4.

\subsubsection{Biosorption efficiency and binding of TPC in cells}

After biosorption, all samples were washed three times using 5\% ethanol solution to remove the remaining PC, separating the supernatants for quantification of TPC. The final pellet loaded with PC was washed with ultrapure water to eliminate residual ethanol. The binding of TPC in cells was calculated by the difference of TPC in plant extracts, catechin solution and 25\% (v/v) ethanol solution (blank) added in the system and TPC in the supernatant of each, respectively (Equation 1). This calculation was performed due to the difficulty of cell disruption after biosorption. TPC was quantified as described in section 6.2.2.2. 


$$
\text { Binding }{ }_{\text {Cells }} \equiv\left(T P C_{\text {Extract added }}-T P C_{\text {Supernatant }}\right) / m_{\text {cells }} \quad \text { Eq. } 1
$$

$\mathrm{TPC}_{\text {Extract added }}-\mathrm{TPC}$ in stock solutions added in the system

TPC Supernatant - TPC in the supernatant

$\mathrm{m}_{\text {Cells }}-$ Mass of cells in the system

In addition, biosorption efficiency (BE\%) was determined as the ratio of the TPC into the cells by the TPC added in the system, as illustrated by Equation 2.

$$
B E(\%)=\left(T P C_{\text {Cells }} / T P C_{\text {Extract added }}\right) * 100 \quad \text { Eq. } 2
$$

\subsubsection{Viability of probiotic cells after biosorption and freeze-drying}

Samples were evaluated regarding the viability of probiotic cells before and after biosorption. Thereafter enumeration, samples were freeze-dried and maintained at $25{ }^{\circ} \mathrm{C}$ for 30 days. Concerning the count of probiotic cells, $0.1 \mathrm{~g}$ of freeze-dried cells were added in $5 \mathrm{~mL}$ of PBS buffer followed by serial dilution. Aliquots were removed from each tube and placed onto MRS agar. Plates were incubated at $37^{\circ} \mathrm{C}$ for $48 \mathrm{~h}$.

6.2.2.8 Evaluation of biosorption of plant extracts in probiotic cells using multiphoton imaging

Regarding the verification of biosorption, only Lacticaseibacillus cells loaded with JP25\% and GSE by vacuum were evaluated by multiphoton imaging, considering a higher level of PC compared with other treatments. First, both extracts were scanned in a Leica TCS SP8 MP multiphoton microscope to check the wavelength of excitation $(K=800 \mathrm{~nm}$ for JP25\% and $K=790$ $\mathrm{nm}$ for GSE) to view the PC. Images of blank cells and cells loaded with extracts were collected in this condition.

6.2.2.9 Stability of PC from JP25\% loaded in probiotic cells during storage 
Stability of JP25\% in probiotic cells was performed after freeze-drying and during storage up to 30 days at $25^{\circ} \mathrm{C}$. Thus, $0.1 \mathrm{~g}$ of freeze-dried cells were added in $2 \mathrm{~mL}$ of acidified methanol solution $(70 \% \mathrm{v} / \mathrm{v})$ and approximately $10 \mathrm{mg}$ of zirconia beads. Samples were vortexed and ultrasonicated (Branson 2510, Branson Ultrasonics) for $10 \mathrm{~min}$, followed by centrifugation at $10,000 \mathrm{rpm}$ for $10 \mathrm{~min}$. Quantification of TPC was carried out as described in section 6.2.2.2.

\subsubsection{Release of phenolic compounds in simulated gastrointestinal conditions}

Evaluation of the release of PC in simulated gastrointestinal fluids was performed according to Minekus et al. (2014) with adaptations. In this way, $1 \mathrm{~g}$ of cell pellet was added in 3 $\mathrm{mL}$ of sterile water for dilution and $4 \mathrm{~mL}$ of simulated gastric fluid (SGF) followed by the adjustment of $\mathrm{pH}$ to 3 and addition of pepsin solution $(2,000 \mathrm{U} / \mathrm{mL})$. The mixture was incubated in a rotary shaker at $100 \mathrm{rpm} / 37^{\circ} \mathrm{C}$ for $2 \mathrm{~h}$. Sequentially, around $5 \mathrm{~mL}$ of simulated intestinal fluid (SIF) was added to the tube, adjusting $\mathrm{pH}$ to 7 . Moreover, $1 \mathrm{~mL}$ of bile salts $(10 \mathrm{mM})$ and $2 \mathrm{~mL}$ of pancreatin $(100 \mathrm{U} / \mathrm{mL})$ solutions were added to the mixture, completing $12 \mathrm{~mL}$. Then, samples were incubated, achieving $4 \mathrm{~h}$ of in vitro test.

Aliquots were withdrawn during this assay ( $\mathrm{t}=1 \mathrm{~h}, 2 \mathrm{~h}, 3 \mathrm{~h}$ and $4 \mathrm{~h})$ to quantify TPC. The control sample (without extract) was carried out as blank. Results were expressed as a percentage of release, considering the quantification of PC in cells and the released in supernatant during the application of simulated gastrointestinal fluids.

\subsection{RESULTS AND DISCUSSION}

\subsubsection{Production of phenolic-rich jabuticaba peel and guaraná seeds (GSE) extracts}

The extraction yield of PC from jabuticaba peel was evaluated as a function of concentration levels of ethanol $(0 \%, 25 \%$ and $50 \% \mathrm{v} / \mathrm{v})$, as illustrated in Table 11 . This extraction approach using ethanol as a solvent was selected as it is a food-grade solvent and has been used in prior studies (SILVA et al., 2019). The results illustrate that extraction time of $2 \mathrm{~h}$ was adequate for recovering PC from the peel, as the TPC values did not differ statistically over an extended time greater than $2 \mathrm{~h}$. Ethanol solutions at $25 \%(\mathrm{v} / \mathrm{v})$ and $50 \%(\mathrm{v} / \mathrm{v})$ increased the recovery of PC 
from the peel compared to pure water extraction. The range of extraction yield values measured based on the TPC value of the extract are similar to the results of previous studies (SANTOS et al., 2010; LENQUISTE et al., 2015), although one of the studies had used a relatively high level of ethanol (99.5\%) to recover $35 \mathrm{mg} \mathrm{GAE} / \mathrm{g}$ of dried peel material. Furthermore, another study has used a combination of ethanol (50\%) and acids to enhance the extraction of PC from jabuticaba peel (BARROS et al., 2019). In this study, the extracted TPC ranged from 16 to $39 \mathrm{mg}$ GAE/g raw peel.

Similarly, Lenquiste et al. (2015) evaluated the effect of water and methanol to extract PC from jabuticaba peel, reporting that methanol increased the recovery of bioactive compounds. The authors also identified some specific phenolics in jabuticaba peel extracts, obtaining higher content of gallic acid and cyanidin-3-O-glucoside in watery extract, while methanolic extract showed higher ellagic acid content. Another study verified that cyanidin-3-glucoside was the major compound extracted from jabuticaba peel using ethanol 50\% (BARROS et al., 2019). In this way, the extracting solutions for recovery of PC from jabuticaba peel affect the phenolics composition. Although the phenolics composition of each extract was not evaluated in this present study, it is expected different biosorption efficiency among the jabuticaba peel extracts due to the varied recovered phenolics and their affinity with the probiotic cell wall.

Table 11 - Phenolic compounds (PC) extracted from jabuticaba peel using different ethanolic solutions and pure water, expressed as mg GAE/g of dried material.

\begin{tabular}{|c|c|c|c|}
\hline \multirow{2}{*}{ Solvent } & \multicolumn{3}{|c|}{ Time of extraction } \\
\hline & $2 \mathrm{~h}$ & $4 \mathrm{~h}$ & $6 \mathrm{~h}$ \\
\hline Water & $36.15 \pm 2.14^{\mathrm{Ab}}$ & $33.72 \pm 0.59^{\mathrm{Ab}}$ & $30.48 \pm 1.54^{\mathrm{Ab}}$ \\
\hline Ethanol 25\% & $48.17 \pm 2.19^{\mathrm{Aa}}$ & $46.76 \pm 2.41^{\mathrm{Aa}}$ & $41.82 \pm 0.51^{\mathrm{Aa}}$ \\
\hline Ethanol $50 \%$ & $51.69 \pm 0.05^{\mathrm{Aa}}$ & $51.93 \pm 1.22^{\mathrm{Aa}}$ & $38.93 \pm 1.01^{\mathrm{Ba}}$ \\
\hline
\end{tabular}

Values with the same upper-case letter in a row and values with the same lower-case letter in a column are not statistically different ( $p>0.05)$. Reference: Own source.

The rehydration of spray-dried GSE was performed by solubility test in ethanol $25 \%$ without causing precipitation (data not shown), selecting the concentration at $7.5 \mathrm{mg}$ of spray- 
dried GSE $/ \mathrm{mL}$ and TPC was around $4.3 \mathrm{mg} \mathrm{GAE} / \mathrm{mL}$ for biosorption in probiotic cells. The chemical composition of this spray-dried GSE was previously reported by Silva et al. (2019), standing out by the high contents of catechins and procyanidins.

Therefore, natural sources of PC are interesting for industrial application instead of chemical standards, extending the health benefits by combining several compounds found in plants. For instance, spray-dried GSE showed anti-obesity potential (SILVA et al., 2019) and jabuticaba peel extract exhibited antioxidant and anti-obesity potential (LENQUISTE et al., 2012). Although chemical standards can be convenient for biosorption design-study, they are costly and limited.

\subsubsection{Vacuum biosorption of jabuticaba peel extracts, GSE and catechin in probiotic cells}

Figure 19 illustrates the influence of vacuum-assisted biosorption of plant extracts on probiotic cells. After vacuum biosorption of JPW, JP25\%, JP50\%, GSE and catechin, loadings of PC in probiotic cells were about 1, 9, 7.5, 4.5 and $4.5 \mathrm{mg} \mathrm{GAE} / \mathrm{g}$, respectively. The results show that compared to passive biosorption process (Figure 20), vacuum-assisted biosorption process results in at least 2-fold increase in both biosorption yield and efficiency across all the ethanolic extracts, while reducing the overall process time by 288 -fold. In probiotic cells loaded with catechin, a 4-fold increase in biosorption yield was observed. This result agrees with another study in which it had demonstrated enhancement in encapsulation yield and efficiency of curcumin in yeast cells using the vacuum infusion process (YOUNG et al., 2017). The improvement of PC binding by vacuum could be attributed to the enlargement of the cell porosity due to the removal of oxygen in the mixture composed of probiotic and plant extracts, which could facilitate the input of PC through the membrane.

Ethanolic extracts improved the binding of PC from jabuticaba peel in probiotic cells by vacuum, showing TPC from 7.5 to $9 \mathrm{mg} \mathrm{GAE} / \mathrm{g}$ of cells and biosorption efficiency at least $35 \%$. This finding can be related to the increment of PC solubility and/or ethanol was able to alter the permeability of the cells, increasing the permeation of these compounds into cells. In addition, the 
ethanolic solutions also influenced the recovery or some specific PC, which could present higher interaction with the cell wall of probiotics.

Figure 19 - Total phenolic content (TPC) in probiotic cells (A, C) and biosorption efficiency (B, D) after vacuum biosorption of jabuticaba peel extracts (JPW - jabuticaba peel in water, JP25\% - jabuticaba peel in $25 \%$ ethanol and JP50\% - jabuticaba peel in 50\% ethanol), guaraná seed extract (GSE) and catechin. Probiotic cells strains were described as LC - L. casei, LR - L. rhamnosus, LP - L. paracasei.

(A)

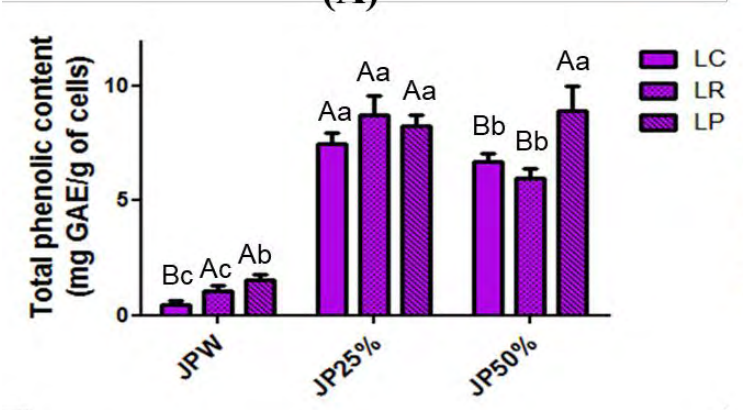

(B)

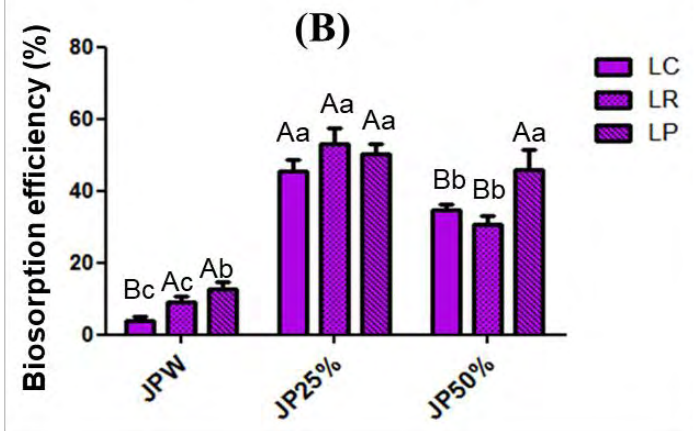

(C)

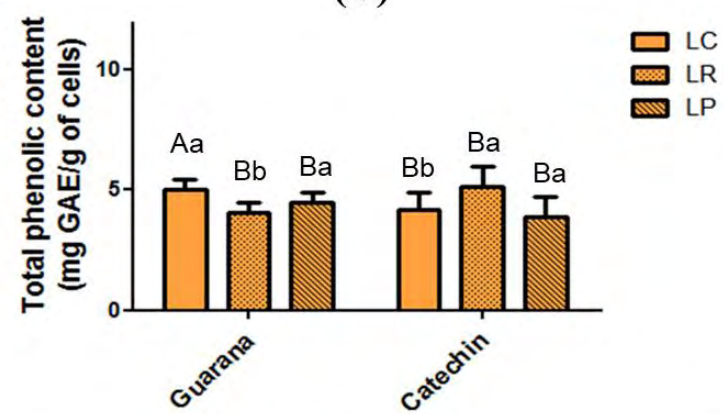

(D)

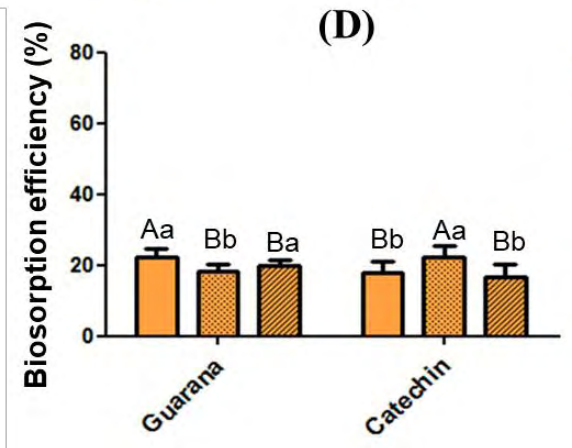

Bars with the same upper-case letter in the same extract and bars with the same lower-case letter of same probiotic cell are not statistically different ( $p>0.05)$. Reference: Own source.

Similarly, Young et al. (2017) evaluated the vacuum infusion of fisetin in yeast cells using $5 \%, 35 \%$ and $50 \%$ ethanol solutions, reaching values ranged from 120 to $230 \mu \mathrm{g}$ of fisetin/g of yeast, depended on the concentration of ethanol solution. Ethanol 35\% was the best solution to infuse fisetin into yeast cells. Another study reported that ethanol $10 \%$ increased 5 times the encapsulation efficiency of Hibiscus sabdariffa extracts in yeast cells compared with water (NGUYEN et al., 2018).

Hence, catechin and GSE were solubilized directly in ethanol $25 \%$ for biosorption in probiotic cells. As a result, the binding of PC from GSE and catechin in probiotic cells was lower, around $5 \mathrm{mg}$ GAE/g of cells, compared with those loaded with JP25\%. Furthermore, the biosorption efficiency of JP25\% in probiotic cells by vacuum was around 55\%, while GSE and 
catechin ranged from $15 \%$ to $20 \%$. The varied chemical composition can explain these differences among the plant extracts, indicating that PC recovered from jabuticaba peels using ethanolic solutions present molecules with higher biosorption affinity than those from GSE and even the catechin solution.

The application of vacuum biosorption for watery jabuticaba peel extract in probiotic cells did not enhance the binding of PC, reaching values around $1 \mathrm{mg} \mathrm{GAE} / \mathrm{g}$ and biosorption efficiency below $15 \%$. As discussed before, watery jabuticaba extract presents as major compounds the cyanidin-3-O-glucoside and gallic acid (LENQUISTE et al., 2015), both phenolic compounds with a low octanol-water partition coefficient $(\log p<1)$. In this way, $\operatorname{low} \log p$ is associated with polar molecules soluble in water, affecting the biosorption due to the low permeability into the cell (HARRIS and LOGAN, 2014; PHAM-HOANG et al., 2016).

In general, the potential of binding in yeast cells is driven by applying low molecular weight compounds, from 200 to $1000 \mathrm{~g} / \mathrm{mol}$ and $\log p$ from 2 to 6 (NELSON et al., 2006). Indeed, the chemical composition of plant extracts influenced the biosorption of $\mathrm{PC}$ in probiotic cells since jabuticaba ethanolic extract is a source of cyanidin chloride and catechin (MACHADO et al., 2018), that present $\log p$ values higher than 2 .

The complex composition of GSE, which simultaneously contains caffeine, catechin, epicatechin and procyanidins, may influence the binding of some molecules in the probiotic cells due to their interaction on the surface. Similarly, the composition of catechin solution used in this study is a mixture of catechins from green tea, showing molecules of a different size that could affect the binding in probiotic cells. Furthermore, another study reported that entry of larger catechins molecules into lipid bilayer was hampered compared with smaller catechins (SIRK et al., 2009). Besides that, the authors noticed that some epigallocatechin gallate molecules were deposited on the lipid bilayer's surface.

The differences among the cell wall compositions could affect the binding capacity of PC in cells-based carriers. However, the probiotic strains used in this experiment did not show significant differences for binding PC due to their similarity. Thus, studies of proteomics may reveal complementary data to predict the binding of specific molecules in cells. Another valuable information is the presence of the peptidoglycan layer in the cell wall of Gram-positive bacteria, 
which increases its rigidity and may hinder the biosorption of some molecules. Nevertheless, the vacuum mechanism was decisive to achieve higher binding of PC compared with the passive biosorption, as discussed in the next session.

\subsubsection{Passive Biosorption of jabuticaba peel extracts, GSE and catechin in probiotic cells}

Figure 20 displays the binding of PC in probiotic cells and biosorption efficiency after passive incubation for $24 \mathrm{~h}$. JPW was an exception among jabuticaba extracts that passive biosorption enhanced PC loading in probiotic cells instead of a vacuum mechanism. The longest contact time between probiotic and JPW during the passive incubation supported the input of PC in probiotic cells. Another possible explanation is the biotransformation of PC by probiotics during the passive incubation, obtaining molecules with higher affinity with the probiotic cell wall. In this sense, jabuticaba by-product showed potential prebiotic activity (MASSA et al., 2020), indicating that probiotics could facilitate the biotransformation of PC from JPW. Despite water favored the passive biosorption of PC from JPW in probiotic cells, ethanolic extracts (JP25\% and JP50\%) provided higher loading of PC in probiotic cells by a passive mechanism that differed statistically. Similarly, Paramera et al. (2011a) reported that curcumin diluted in water increased the encapsulation efficiency in yeast cells by passive mechanism compared with $50 \%$ ethanol solution due to the ethanol interaction into binding sites in yeast membrane.

In addition, low PC loading in probiotic cells after passive mechanism can be associated with the choice of parameters. For example, the low temperature applied during the passive incubation aimed to maintain the viability of probiotic cells. Still, it could reduce the membrane fluidity hindering the biosorption of PC in probiotic cells. Besides that, prolonged incubation time may affect the stability of PC, compromising the loading of PC in probiotic cells. Another study evaluated that temperature above $35^{\circ} \mathrm{C}$ increased the fluidity of yeast's cell membrane, enhancing the input of bioactive compound during passive diffusion (PARAMERA et al., 2011a).

Moreover, the factors that can trigger the biosorption of plant extracts in probiotic cells are the physicochemical properties of cells and PC, such as their hydrophobicity, electrostatic interactions, and stability in solution. In this context, PC may interact with proteins on the cell wall 
surface, inside cells and lipid compartments, depending on their polarity and charge. For example, another study reported that polyphenols bound selectively with different plant cell wall components, showing that catechin presents high affinity to cellulose and charge effect importance for non-covalent interaction (PHAN et al., 2017). Besides that, some studies correlated the relevance of molecular weight, structural flexibility and quantity of $\mathrm{OH}$ groups to provide the binding of PC in proteins (FRAZIER et al., 2010, JAKOBEK, 2015).

Figure 20 - Total phenolic content (TPC) in probiotic cells (A, C) and biosorption efficiency (B, D) after passive of jabuticaba peel extract (JPW - jabuticaba peel in water, JP25\% - jabuticaba peel in 25\% ethanol and JP50\% - jabuticaba peel in 50\% ethanol), guaraná seed extract (GSE) and catechins. Probiotic cells strains were described as LC - L. casei, LR - L. rhamnosus, LP - L. paracasei.
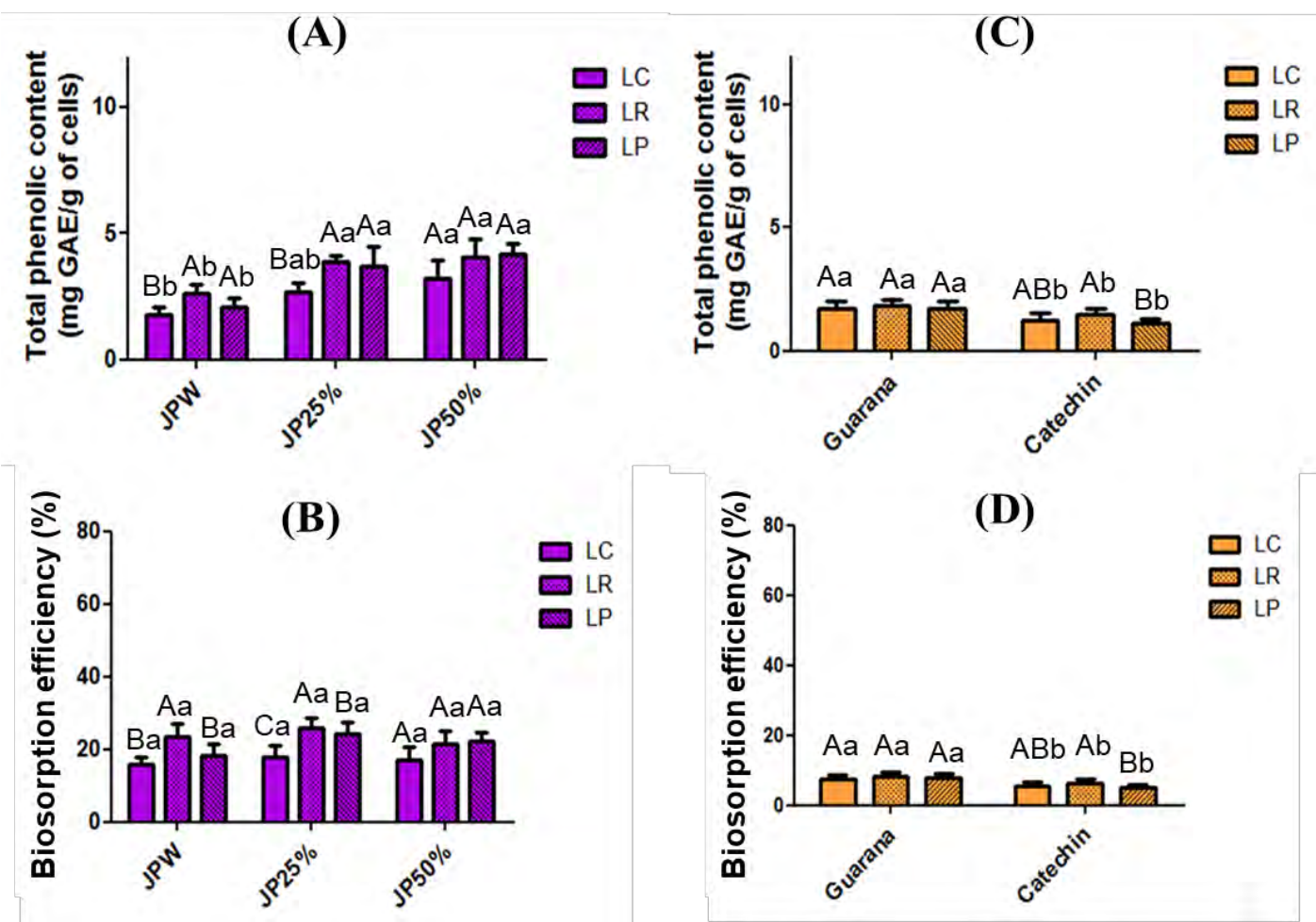

Bars with the same upper-case letter in the same extract and bars with the same lower-case letter of same probiotic cell are not statistically different ( $p>0.05)$. Reference: Own source.

Although this study did not use single catechin for biosorption, only the group of catechins from green tea was tested; the results inferred that varied composition of GSE, including catechins and procyanidins (SILVA et al., 2019), did not affect the biosorption of PC significantly. In addition, the application of catechin solution did not increase the loading of PC in probiotic cells, as can be correlated with the low value of $\log p$. Regarding the affinity of catechins in the probiotic 
cell wall, the peptidoglycan layer may contribute to their binding. For instance, another study verified that epigallocatechin gallate was bound to the peptidoglycan layer of Staphylococcus aureus (YODA et al., 2003). This mechanism was involved with the damage of S. aureus cell wall. For this reason, the viability of probiotic cells after biosorption, freeze-drying and storage was evaluated in this study.

Most of the studies have been using pure compounds for biosorption in cells (PARAMERA et al. 2011a, YOUNG et al., 2017), which is valuable to predict the binding interaction during this process. However, applying food by-products to recover bioactive compounds followed by encapsulation is an eco-friendly trend (RUBIO et al., 2020; COMUNIAN et al., 2021). The main concern of this approach is related with the multiple bioactive compounds that can be found in plants, which may interact with specific sites in membrane cell, affecting the biosorption.

Thus, the application of ethanol $25 \%$ and vacuum mechanism showed be the best approach for biosorption of PC from plant extracts in probiotic cells, besides being a quick process, which could be scaled to the industrial process. Furthermore, other parameters adjustments during vacuum biosorption, such as $\mathrm{pH}$ and different concentrations of bioactive compounds, could increase the loading of phenolics and biosorption efficiency.

\subsubsection{Multiphotonic microscopy and stability of TPC}

Probiotic cells were evaluated by multiphotonic microscopy to confirm JP25\% and GSE biosorption in probiotic cells, as exhibited in Figure 21. Probiotic cells showed the typical rod shape and size ranging around $1 \mu \mathrm{m}$ by $5 \mu \mathrm{m}$. Control cells (A, C, E, G) emitted low fluorescence in the experiment conditions, while cells loaded with JP25\% (B, D, F) and GSE (H) were fluorescent. Although the loading of JP25\% in probiotics strains (results showed in Fig. 1) did not differ significantly, the micrograph of LC (Fig. 20 D) exhibited the highest fluorescence. Differences between the composition and polarity of the cell wall may influence these findings. Besides that, LC loaded with GSE (Fig. $20 \mathrm{H}$ ) showed lower fluorescence than that loaded with JP25\%, which could be correlated with the reduced loading of PC in probiotic cells, as previously discussed. These images are in accordance with another study that produced yeast cells loaded 
with fisetin and curcumin (YOUNG et al., 2017), demonstrating by fluorescence the presence of bioactive compounds in cells after vacuum mechanism.

Figure 21 - Micrographs of probiotic cells after vacuum biosorption (VB) of ethanol 25\% (controls), JP25\% - jabuticaba peel in 25\% ethanol, and GSE - guaraná seed extract. In this figure: A) L. rhamnosus (LR) loaded with ethanol 25\%; B) LR loaded with JP25\%; C) L. casei (LC) loaded with ethanol 25\%; D) LC loaded with JP25\%; E) L. paracasei (LP) loaded with ethanol; F) LP loaded with JP25\%; G) LC loaded with ethanol 25\%; H) LC loaded with GSE.

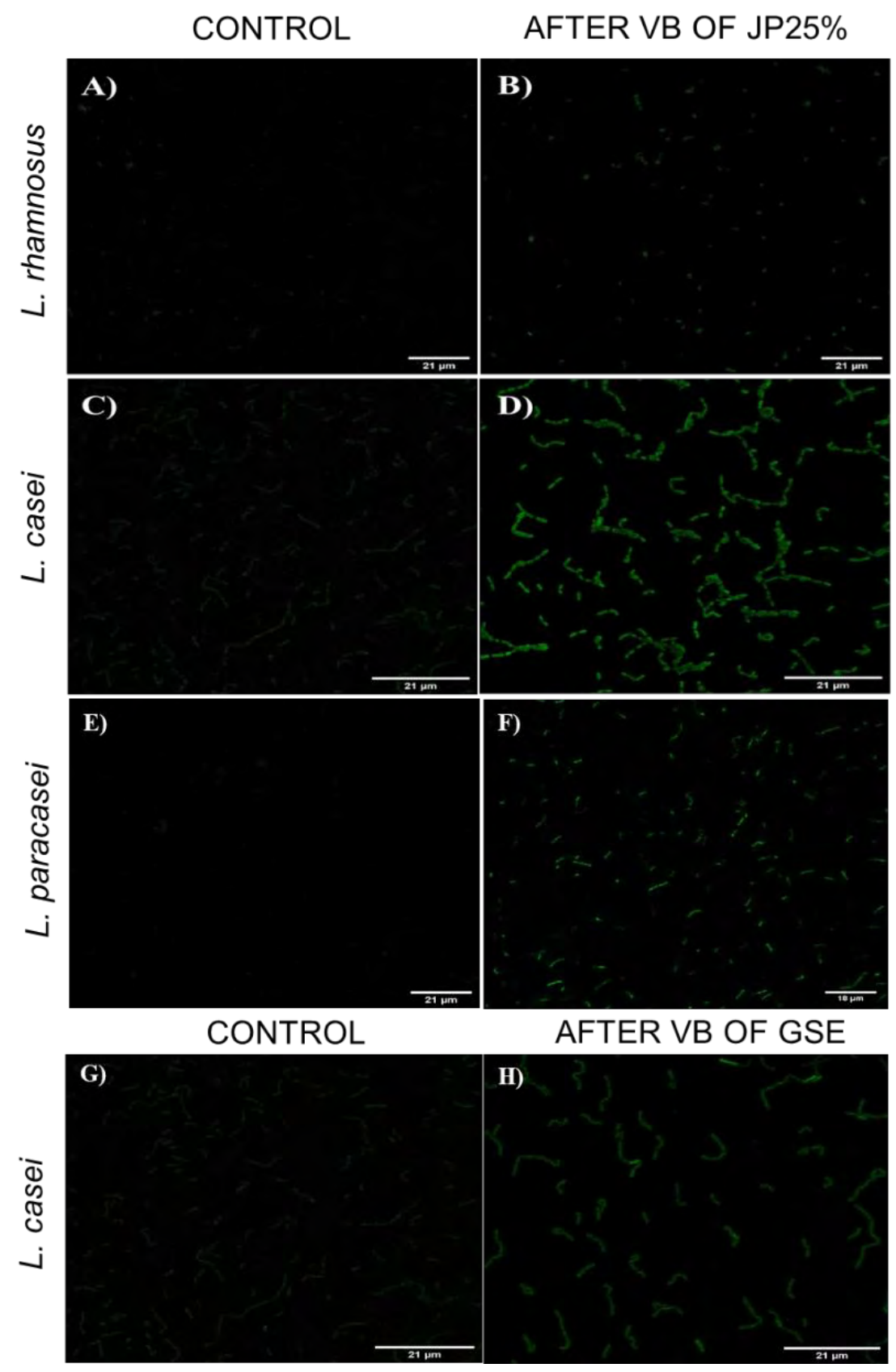

Reference: Own source. 
Concerning the stability of TPC from JP25\% loaded with Lacticaseibacillus cells, the recovery values were lower than found after vacuum biosorption, as shown in Table 12. These findings may have been influenced by the challenge of lysing the cell wall of Gram-Positive bacteria, considering the peptidoglycan layer. In addition, although the recovery extraction of TPC was optimized, probiotic cells were not totally discolored after this process, indicating that part of $\mathrm{PC}$ remained in the cells.

However, PC evaluation in probiotic cells is an interesting estimation for understanding if these bioactive compounds were protected after biosorption. In this way, TPC loaded in LP decreased around $1.6 \mathrm{mg} \mathrm{GAE} / \mathrm{g}$ stored at $25^{\circ} \mathrm{C}$ for 30 days. A possible explanation is that JP25\% may interact with the cell wall, adsorbing on the surface of this bacteria. Furthermore, exposure to oxygen can degrade PC, demonstrating that LP cell was insufficient to protect PC during storage.

Another study reported that relative humidity affected the stability of curcumin in yeast and other carriers (PARAMERA et al., 2011b). It is important to highlight those powders produced in this study were not stored in desiccators, which could control the humidity of samples. However, TPC values found in LC and LR cells demonstrated that these strains protected PC since these values did not differ significantly during storage.

Table 12 - Stability of phenolic compounds encapsulated in Lacticaseibacillus cells, expressed as mg $\mathrm{GAE} / \mathrm{g}$ of cell.

\begin{tabular}{cccc}
\hline Cells & 0 & $15 \mathrm{~d}$ & $30 \mathrm{~d}$ \\
\hline L. casei & $4.09 \pm 0.28^{\mathrm{Aa}}$ & $4.30 \pm 0.60^{\mathrm{ABa}}$ & $4.50 \pm 0.38^{\mathrm{Aa}}$ \\
L. rhamnosus & $4.70 \pm 0.32^{\mathrm{Aa}}$ & $4.88 \pm 0.68^{\mathrm{Aa}}$ & $4.83 \pm 0.25^{\mathrm{Aa}}$ \\
L. paracasei & $4.14 \pm 0.40^{\mathrm{Aa}}$ & $3.31 \pm 0.45^{\mathrm{Bab}}$ & $2.53 \pm 0.36^{\mathrm{Bb}}$
\end{tabular}

Values with the same upper-case letter in a column and same lower-case letter in a row are not statistically different ( $p>0.05)$. Reference: Own source. 


\subsubsection{Release of PC in simulated gastrointestinal conditions}

\subsubsection{Liberation of PC in gastric fluid}

The study of PC release in simulated gastrointestinal fluids may contribute to understanding the protection afforded by cells during digestion. Figure 22 displays the percentage of PC released from probiotic cells in simulated gastric fluid (SGF) for $2 \mathrm{~h}$ followed by the sequential application of simulated intestinal fluid (SIF), completing $4 \mathrm{~h}$ of in vitro digestion test. We selected only the probiotic cells loaded with JP25\%, GSE and catechin standard by vacuum biosorption due to the higher content of PC.

Although the probiotic cell wall presents peptides linked with polysaccharides, the composition of SGF did not allow a high release of PC, which is desirable since the PC will be metabolized in the intestinal phase. In this way, probiotic cells loaded with JP25\% and GSE liberated around $20 \%$ of PC in SGF after $2 \mathrm{~h}$, while probiotic cells loaded with catechin standard released about $40 \%$ of PC in SGF at the same time. This higher liberation of PC from probiotic cells loaded with catechin could be explained by the low affinity of catechin to the cells. Besides that, if there was an electrostatic interaction between the cell surface and catechin, the low $\mathrm{pH}$ of SGF may have changed that interaction.

Among the probiotic strains studied, LP and LC exhibited higher release of PC from JP25\% and GSE, respectively. Correlating this result for LP cells loaded with JP25\% and its stability during storage (Table 12), probably part of the PC was bound into surface sites of LP, facilitating their release in SGF. In addition, the study of intrinsic characteristics of LP and LC cell walls by proteomic assays could be an essential tool for evaluating responsible proteins for binding the PC.

Similarly, Young et al. (2020) investigated the effect of simulated gastrointestinal fluids to release curcumin encapsulated in yeast cells. The authors noticed that SGF containing pepsin enzyme did not change the yeast cell wall, confirming by transmission electron microscopy. Despite the differences between yeast and bacteria cell walls, SGF did not significantly affect the probiotic cell since most PC from plant extracts remained entrapped. 
Figure 22 - Release of PC from probiotic cells loaded with JP25\% - jabuticaba peel in 25\% ethanol (A), GSE - guaraná seed extract (B) and catechins (C) in simulated gastric fluid (SGF) and sequential addition of simulated intestinal fluid (SIF), expressed as percentage of TPC released in the fluids. In this Figure: LC - L. casei loaded with phenolic compounds from plant extracts or catechin standard, LR - L. rhamnosus loaded with phenolic compounds from plant extracts or catechin standard, LP $-L$. paracasei loaded with phenolic compounds from plant extracts or catechin standard.

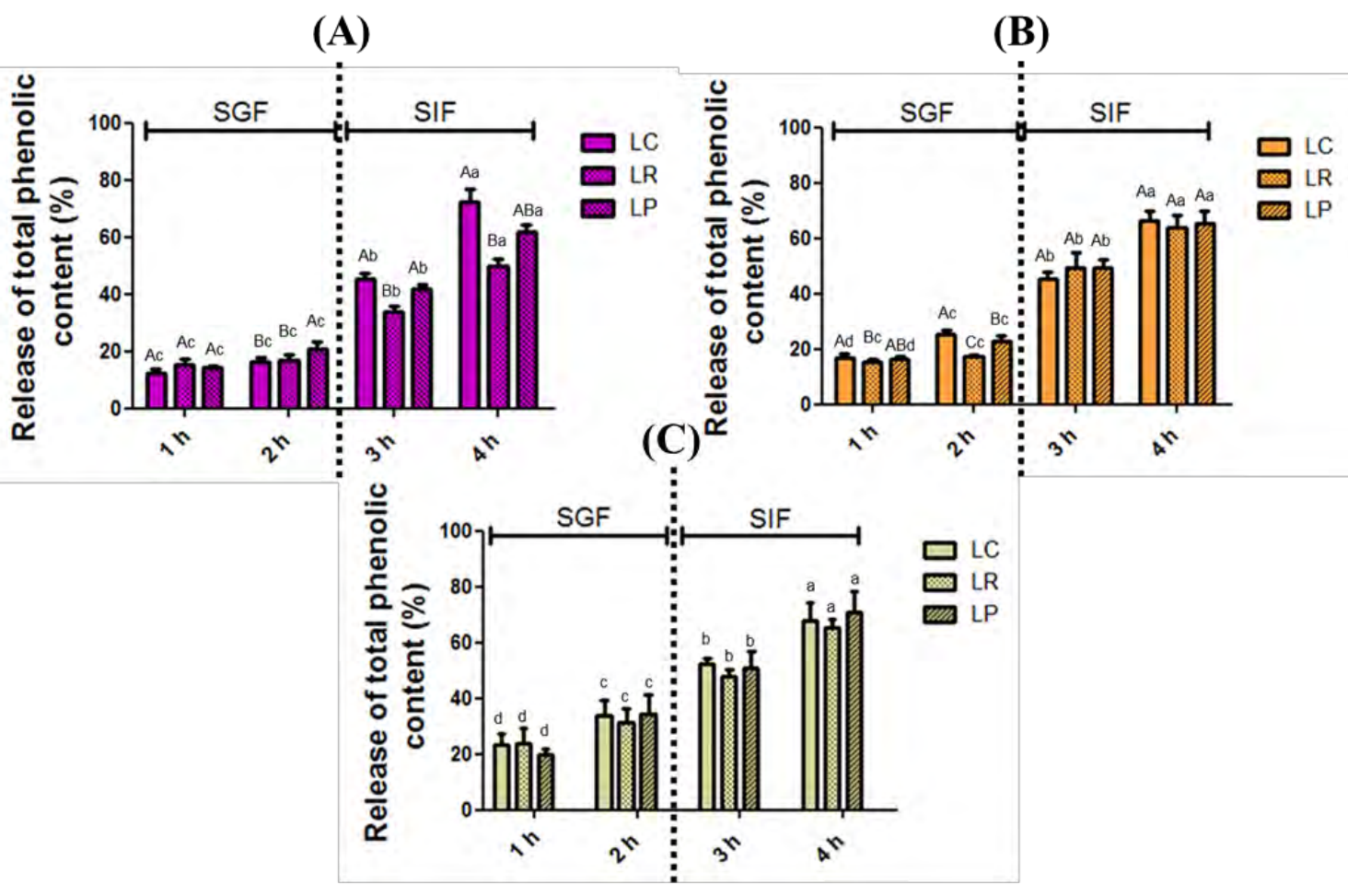

Bars with the same upper-case letter in the same time interval and bars with the same lower-case letter of same treatment are not statistically different ( $p>0.05)$. Reference: Own source.

In contrast, Shi et al. (2008) reported the release of encapsulated resveratrol in yeast cells was around $85 \%$ in SGF after 50 min. Thus, although the cell wall composition drives the release mechanism in simulated gastrointestinal fluids, the characteristics of bioactive compounds bound in the cell are also relevant to predict their liberation. In this present study, the complex composition of plant extracts achieved a gradual release, as discussed in the next section.

\subsubsection{Liberation in intestinal fluid}

In general, the addition of SIF, composed of a mixture of salts, bile and pancreatin solutions, during the in vitro digestion assay is decisive to release the entrapped bioactive 
compounds since they may complete the digestion. As we expected, SIF increased the liberation of PC from JP25\%, reaching values around 75\%, 55\% and 62\% of PC released from the LC, LR and LP, respectively. Some PC from JP25\% could be bounded in lipid compartments of probiotic cells, which were affected by the addition of SIF. Besides that, these results differed among the strains due to the cell wall composition and polarity, which would determine its permeability.

A similar profile was noticed for probiotic cells loaded with GSE and catechin, increasing the release around $65 \%$ and $70 \%$ of PC in SIF, respectively. Furthermore, the probiotic strains did not differ during the liberation of PC in SIF, indicating a weak affinity of these bioactive compounds in probiotic cells regardless of cell wall composition.

Young et al. (2020) reported the relevance of pancreatin and bile salts to release phytochemical encapsulated in yeast cells, causing denaturation and/or disruption of the binding site. Likewise, Rai et al. (2021) encapsulated trans-resveratrol in grape skin powder by vacuum infusion, reporting a liberation of around $90 \%$ of trans-resveratrol in SIF. Despite the difference between the carriers, a vacuum mechanism was applied in both studies, showing that this method effectively binds bioactive compounds and releases them in simulated gastrointestinal conditions.

Similar release values were reported by other studies, which verified the jabuticaba peel powder and solid lipid microparticles loaded with GSE during in vitro digestion assay (INADA et al., 2020; SILVA et al., 2019). For instance, the application of intestinal fluid increased the liberation of ellagic acid from jabuticaba peel powder, reaching the bioaccessibility of $49 \%$ of PC (INADA et al., 2020). Besides that, the authors verified the anthocyanins were unstable in the intestinal fluid because of the alkaline medium. Concerning the release of PC from solid lipid microparticles loaded with GSE, the liberation was at least $69 \%$ of TPC in simulated gastrointestinal fluids (SILVA et al., 2019). In this way, the binding of PC from plant extracts in probiotic cells was not stable, allowing the delivery of PC in the gut, which is relevant and desirable since PC are metabolized in the colon by gut microbiota. 


\subsubsection{Viability of probiotic cells after biosorption and freeze-drying}

Table 13 illustrates the viability of probiotic cells immediately after biosorption using vacuum and passive mechanisms followed by freeze-drying. After biosorption of ethanol $25 \%$ (control), JPW, JP25\%, GSE and catechin solution, probiotic cells showed a count of at least 9.3 $\log \mathrm{CFU} / \mathrm{g}$. The initial probiotic population was around $10 \log \mathrm{CFU} / \mathrm{g}$ (data not shown), demonstrating that biosorption mechanisms did not immediately affect the viability of probiotic cells.

Concerning the enumeration of probiotic cells after biosorption of JP50\%, counts were below the detection limit of $3 \mathrm{log} \mathrm{CFU} / \mathrm{g}$, which was expected since probiotics are sensitive to ethanol at high concentration levels. For this reason, these results were not included, as well as these cells loaded with JP50\% were not freeze-dried. However, these results proved that vacuum biosorption of plant extracts and catechin solution in probiotic cells, even in the presence of ethanol $25 \%$, provided a higher number of viable cells.

In relation to the freeze-drying of cells loaded with ethanol 25\% (control), extracts and catechin, the enumeration of the probiotic population varied from 10.8 to $8.2 \log \mathrm{CFU} / \mathrm{g}$, as can be seen in Table 3. In this way, the reduction of viability of probiotic cells after freeze-drying may have been influenced by the biosorption mechanism and/or the concentration of PC in probiotic cells due to dehydration.

The enumerations of freeze-dried cells treated with vacuum were at least $9.9 \mathrm{log}$ CFU/g of probiotic cells, demonstrating another technological advantage of vacuum mechanism since the maintenance of probiotic viability is requested to provide benefits to the host. Besides that, the fast contact time $(5 \mathrm{~min})$ of probiotic cells with ethanol $25 \%$ reduced this stress condition, providing a high viability. 
Table 13 - Viability of probiotic cells, L. casei (LC), L. paracasei (LP) and L. rhamnosus (LR) after biosorption by vacuum (V) or passive (P) mechanisms and freeze-drying, expressed as log CFU/g.

\begin{tabular}{|c|c|c|c|c|c|c|c|}
\hline \multirow{2}{*}{ Treatments } & \multirow{2}{*}{ Mechanism } & \multicolumn{2}{|c|}{$\mathrm{LC}$} & \multicolumn{2}{|c|}{ LP } & \multicolumn{2}{|c|}{ LR } \\
\hline & & Biosorption & Freeze-dried & Biosorption & Freeze-dried & Biosorption & Freeze-dried \\
\hline \multirow{2}{*}{ Control } & $\mathrm{V}$ & $10.25 \pm 0.16^{\mathrm{ABa}}$ & $10.38 \pm 0.41^{\mathrm{Aa}}$ & $10.20 \pm 0.28^{\mathrm{Aa}}$ & $10.38 \pm 0.36^{\mathrm{ABa}}$ & $10.38 \pm 0.43^{\mathrm{Aa}}$ & $10.35 \pm 0.30^{\mathrm{ABa}}$ \\
\hline & $\mathrm{P}$ & $9.93 \pm 0.34^{\mathrm{BCab}}$ & $10.46 \pm 0.63^{\mathrm{Aa}}$ & $9.64 \pm 0.35^{\mathrm{Cb}}$ & $10.21 \pm 0.32^{\mathrm{ABa}}$ & $9.91 \pm 0.24^{\mathrm{Bab}}$ & $10.33 \pm 0.37^{\mathrm{ABa}}$ \\
\hline \multirow{2}{*}{ JPW } & V & $10.40 \pm 0.22^{\mathrm{ABa}}$ & $10.54 \pm 0.42^{\mathrm{Aa}}$ & $10.45 \pm 0.24^{\mathrm{Aa}}$ & $10.66 \pm 0.25^{\mathrm{Aa}}$ & $10.39 \pm 0.27^{\mathrm{Aa}}$ & $10.34 \pm 0.27^{\mathrm{ABa}}$ \\
\hline & $\mathrm{P}$ & $10.67 \pm 0.50^{\mathrm{Aa}}$ & $10.39 \pm 0.40^{\mathrm{Aa}}$ & $10.18 \pm 0.26^{\mathrm{ABa}}$ & $8.90 \pm 0.43^{\mathrm{Cb}}$ & $10.36 \pm 0.12^{\mathrm{Aa}}$ & $10.77 \pm 0.64^{\mathrm{Aa}}$ \\
\hline \multirow{2}{*}{ JP25\% } & V & $10.34 \pm 0.27^{\mathrm{ABa}}$ & $9.91 \pm 0.48^{\mathrm{Aa}}$ & $10.16 \pm 0.22^{\mathrm{ABa}}$ & $10.24 \pm 0.23^{\mathrm{ABa}}$ & $10.23 \pm 0.29^{\mathrm{ABa}}$ & $10.09 \pm 0.31^{\mathrm{Ba}}$ \\
\hline & $\mathrm{P}$ & $9.71 \pm 0.56^{\mathrm{Cab}}$ & $8.79 \pm 0.60^{\mathrm{Bcd}}$ & $10.01 \pm 0.26^{\mathrm{BCa}}$ & $8.22 \pm 0.60^{\mathrm{Dd}}$ & $9.29 \pm 0.44^{\mathrm{Cbc}}$ & $10.15 \pm 0.19^{\mathrm{Ba}}$ \\
\hline \multirow{2}{*}{ GSE } & V & $10.31 \pm 0.19^{\mathrm{ABa}}$ & $10.09 \pm 0.53^{\mathrm{Aa}}$ & $10.28 \pm 0.17^{\mathrm{ABa}}$ & $10.44 \pm 0.17^{\mathrm{ABa}}$ & $10.32 \pm 0.20^{\mathrm{ABa}}$ & $10.32 \pm 0.15^{\mathrm{ABa}}$ \\
\hline & $\mathrm{P}$ & $9.97 \pm 0.30^{\mathrm{BCb}}$ & $10.46 \pm 0.37^{\mathrm{Aa}}$ & $9.98 \pm 0.31^{\mathrm{BCb}}$ & $10.14 \pm 0.32^{\text {Bab }}$ & $10.19 \pm 0.19^{\mathrm{ABab}}$ & $10.37 \pm 0.26^{\mathrm{ABab}}$ \\
\hline \multirow{2}{*}{ Catechin } & V & $10.34 \pm 0.15^{\mathrm{ABab}}$ & $10.29 \pm 0.20^{\mathrm{Aab}}$ & $10.45 \pm 0.12^{\mathrm{Aa}}$ & $10.51 \pm 0.25^{\mathrm{ABa}}$ & $10.44 \pm 0.30^{\mathrm{Aa}}$ & $10.03 \pm 0.47^{\mathrm{Bb}}$ \\
\hline & $P$ & $10.22 \pm 0.22^{\mathrm{ABab}}$ & $10.51 \pm 0.34^{\mathrm{Aa}}$ & $10.11 \pm 0.23^{\mathrm{ABb}}$ & $10.30 \pm 0.16^{\mathrm{ABab}}$ & $10.23 \pm 0.28^{\mathrm{ABab}}$ & $10.26 \pm 0.19^{\mathrm{ABab}}$ \\
\hline
\end{tabular}


In contrast, probiotic cells treated by passive biosorption with JP25\% exhibited a significant reduction in viability for LP and LC after freeze-drying, showing counts about 8.8 and $8.2 \log$ CFU/g respectively. These results could be related to the presence of ethanol during passive biosorption of $24 \mathrm{~h}$, promoting late adverse effects on the probiotic population. However, the passive biosorption of JPW in LP also influenced its viability after freeze-drying since the counts of the probiotic population decreased around $1 \log$ CFU/g. Thus, although the JPW did not contain ethanol as a solvent, other compounds after concentration by freeze-drying may have affected the viability of LP treated by a passive mechanism. In this way, LP may not tolerate prolonged contact by passive biosorption of some compounds found in JPW. At the same time, LC and LR were not affected by JPW composition since their viability did not differ significantly after freeze-drying.

The counts were maintained concerning the freeze-dried probiotic cells loaded with GSE and catechin, also solubilized in ethanol $25 \%$ regardless of biosorption mechanism. These results indicated that their chemical composition and antioxidant potential possibly reduced the oxidative stress of probiotic cells, improving their survivability after freeze-drying. Some studies demonstrated the positive effect of polyphenols during incubation with probiotics (MILUTINOVIC et al., 2021; MASSA et al., 2020). However, the chemical composition of PC found in plant extracts and its concentration may stimulate or inhibit some probiotic strains (MILUTINOVIC et al., 2021). As discussed in section 6.3.1, the PC composition of jabuticaba peels extracts may vary depending on the extraction solution to recovery PC, but anthocyanins represent the major PC, such as cyanidin-3-glucoside and cyanidin-3-O-glucoside. In contrast, GSE present catechins and procyanidins as the major PC. Therefore, the differences found for the viability of probiotic cells loaded with jabuticaba extracts, GSE and catechin solution can be correlated with the varied chemical composition of PC and their concentrations.

\subsubsection{Viability of freeze-dried probiotics loaded with plants extracts and catechin during the storage at $25^{\circ} \mathrm{C}$ for 30 days}

Table 14 displays the viability of freeze-dried probiotic cells during the storage at $25{ }^{\circ} \mathrm{C}$ for 30 days. The recommended daily dose is above $6 \log$ CFU/g to get the beneficial effects of probiotics (TRIPHATI and GIRI, 2014), and most of the treatments reached this count. The freeze- 
dried probiotic cells loaded with GSE and catechin exhibited higher values of viability during storage at $25^{\circ} \mathrm{C}$ for 30 days, varying from 8 to $10 \log \mathrm{CFU} / \mathrm{g}$, regardless of biosorption mechanism and probiotics strains. These findings may be related to the presence of catechin, known as an antioxidant compound, reducing the oxygen toxicity on specific probiotic strains (GAUDREAU et al., 2013).

On the other hand, freeze-dried LC and LP loaded with JP25\% by passive biosorption showed low counts around 4.5 and $4.6 \log \mathrm{CFU} / \mathrm{g}$, respectively. Besides that, the populations of LC cells loaded with JPW by passive biosorption decreased about $5 \log \mathrm{CFU} / \mathrm{g}$, considering the enumerations after freeze-drying (Table 13) and 30 days of storage (Table 14). However, the viability of LC loaded with ethanol $25 \%$ (control) by passive biosorption was around $8.1 \log$ $\mathrm{CFU} / \mathrm{g}$. For this reason, LC cells may be sensitive to the concentrated bioactive compounds of jabuticaba peel extracts. Furthermore, freeze-drying increases the concentration of PC in probiotic cells, which in excess can act as a prooxidant and causes probiotic death.

Among freeze-dried probiotic cells loaded with jabuticaba extracts, LR showed the highest viability, ranging from 8.8 to $6.1 \log \mathrm{CFU} / \mathrm{g}$. Furthermore, most of the samples that presented higher viability were produced by vacuum biosorption, demonstrating other advantages of this process compared with the passive mechanism. Another alternative to enhance the viability of freeze-dried probiotic cells would be applying cryoprotective agents, avoiding damage to the probiotic cell. For instance, Jalali et al. (2012) evaluated the effect of cryoprotective agents for freeze-drying of L. paracasei subsp. tolerance, showing counts around $10 \mathrm{log}$ CFU/g and $6 \log$ $\mathrm{CFU} / \mathrm{g}$ for cells loaded with and without cryoprotectant, respectively, after 3 months of storage at $23{ }^{\circ} \mathrm{C}$. 
Table 14 - Viability of L. casei (LC), L. paracasei (LP) and L. rhamnosus (LR) after 15 and 30 days of storage at $25^{\circ} \mathrm{C}$, expressed as log CFU/g.

\begin{tabular}{|c|c|c|c|c|c|c|c|}
\hline \multirow{2}{*}{ Treatments } & \multirow{2}{*}{ Mechanism } & \multicolumn{2}{|c|}{$\mathrm{LC}$} & \multicolumn{2}{|c|}{ LP } & \multicolumn{2}{|c|}{ LR } \\
\hline & & $15 \mathrm{~d}$ & $30 \mathrm{~d}$ & $15 \mathrm{~d}$ & $30 \mathrm{~d}$ & $15 \mathrm{~d}$ & $30 \mathrm{~d}$ \\
\hline \multirow{2}{*}{ Control } & V & $9.36 \pm 0.57^{\mathrm{Ba}}$ & $8.93 \pm 0.17^{\mathrm{Ba}}$ & $9.28 \pm 0.26^{\mathrm{BCa}}$ & $8.31 \pm 0.22^{\mathrm{Ab}}$ & $9.40 \pm 0.44^{\mathrm{BCa}}$ & $8.33 \pm 0.29^{\mathrm{CDb}}$ \\
\hline & $\mathrm{P}$ & $9.31 \pm 0.33^{\mathrm{Ba}}$ & $8.10 \pm 0.24^{\mathrm{CDc}}$ & $8.89 \pm 0.29^{\mathrm{Cb}}$ & $7.11 \pm 0.20^{\mathrm{Cd}}$ & $7.72 \pm 0.38^{\mathrm{Fc}}$ & $5.45 \pm 0.26^{\mathrm{Ge}}$ \\
\hline \multirow{2}{*}{ JPW } & V & $8.94 \pm 0.22^{\mathrm{Bb}}$ & $7.17 \pm 0.33^{\mathrm{Ed}}$ & $8.39 \pm 0.25^{\mathrm{Dc}}$ & $6.47 \pm 0.38^{\mathrm{DEe}}$ & $9.84 \pm 0.36^{\mathrm{Ba}}$ & $8.77 \pm 0.25^{\mathrm{BCbc}}$ \\
\hline & $P$ & $8.03 \pm 0.29^{\mathrm{Cb}}$ & $5.05 \pm 0.27^{\mathrm{Ge}}$ & $7.11 \pm 0.23^{\mathrm{Ec}}$ & $6.04 \pm 0.36^{\mathrm{Ed}}$ & $8.64 \pm 0.37^{\mathrm{DEa}}$ & $6.16 \pm 0.23^{\mathrm{Fd}}$ \\
\hline \multirow{2}{*}{ JP25\% } & V & $7.99 \pm 0.32^{\mathrm{Ca}}$ & $5.81 \pm 0.36^{\mathrm{Fd}}$ & $8.16 \pm 0.23^{\mathrm{Da}}$ & $6.57 \pm 0.34^{\mathrm{Dc}}$ & $8.30 \pm 0.24^{\mathrm{Ea}}$ & $7.47 \pm 0.29^{\mathrm{Eb}}$ \\
\hline & $\mathrm{P}$ & $7.13 \pm 0.33^{\mathrm{Dc}}$ & $4.45 \pm 0.36^{\mathrm{Hd}}$ & $6.80 \pm 0.28^{\mathrm{Ec}}$ & $4.62 \pm 0.33^{\mathrm{Fd}}$ & $9.03 \pm 0.24^{\mathrm{CDa}}$ & $8.15 \pm 0.36^{\mathrm{Db}}$ \\
\hline \multirow{2}{*}{ GSE } & V & $10.27 \pm 0.19^{\mathrm{Aa}}$ & $10.43 \pm 0.13^{\mathrm{Aa}}$ & $9.27 \pm 0.14^{\mathrm{BCb}}$ & $7.99 \pm 0.45^{\mathrm{Bc}}$ & $10.57 \pm 0.14^{\mathrm{Aa}}$ & $10.51 \pm 0.31^{\mathrm{Aa}}$ \\
\hline & $\mathrm{P}$ & $8.10 \pm 0.26^{\mathrm{Cb}}$ & $7.98 \pm 0.24^{\mathrm{Db}}$ & $9.73 \pm 0.30^{\mathrm{Aa}}$ & $9.45 \pm 0.21^{\mathrm{Aa}}$ & $8.21 \pm 0.38^{\mathrm{Eb}}$ & $8.33 \pm 0.33^{\mathrm{CDb}}$ \\
\hline \multirow{2}{*}{ Catechin } & V & $10.46 \pm 0.18^{\mathrm{Aa}}$ & $10.32 \pm 0.27^{\mathrm{Aa}}$ & $9.14 \pm 0.44^{\mathrm{BCb}}$ & $7.30 \pm 0.40^{\mathrm{Cc}}$ & $10.48 \pm 0.19^{\mathrm{Aa}}$ & $10.48 \pm 0.13^{\mathrm{Aa}}$ \\
\hline & $\mathrm{P}$ & $8.94 \pm 0.42^{\mathrm{Bb}}$ & $8.48 \pm 0.14^{\mathrm{Cc}}$ & $9.37 \pm 0.24^{\mathrm{ABa}}$ & $9.26 \pm 0.17^{\mathrm{Aab}}$ & $9.24 \pm 0.23^{\mathrm{Cab}}$ & $8.89 \pm 0.44^{\mathrm{Bbc}}$ \\
\hline
\end{tabular}

Values with the same upper-case letter in a column and same lower-case in a row are not statistically different (p>0.05). 


\subsection{CONCLUSIONS}

These findings provide experimental proof that probiotic cells may load PC from plant extracts. Among the extraction solutions, 25\% ethanol solution (JP25\%) increased the biosorption of PC from jabuticaba peel in Lacticaseibacillus cells, but the 50\% ethanol solution (JP50\%) did not maintain probiotic cells viable, as expected. Concerning the mechanisms of biosorption, vacuum enhanced the PC in probiotic cells and probiotic viability, besides being a fast process compared with the conventional passive mechanism. Furthermore, the chemical composition of plant extracts plays an important role in biosorption due to the higher loading of JP25\%, which is a source of anthocyanin known as hydrophobic, in probiotic cells around $9 \mathrm{mg} \mathrm{GAE} / \mathrm{g}$ of probiotic cells. Despite the decrease of the probiotic population during storage, LR showed counts above 7 $\log \mathrm{CFU} / \mathrm{g}$ and TPC around $5 \mathrm{mg} \mathrm{GAE} / \mathrm{g}$ up to 30 days at $25^{\circ} \mathrm{C}$. The release profile of PC in simulated gastrointestinal fluids depended on the probiotic strain, but at least $55 \%$ of PC was released. Further studies should be performed to understand the individual affinity of each PC on the probiotic strains, as well as the in-vivo validation for the delivery of PC in the colon.

\section{ACKNOWLEDGMENTS}

Marluci P. da Silva thanks the São Paulo Research Foundation (FAPESP) for the scholarship awarded (grant \#2016/24895-5 and grant \#2019/09757-3).

\section{REFERENCES}

AINSWORTH, E.; GILLESPIE, K. Estimation of total phenolic content and other oxidation substrates in plant tissues using Folin-Ciocalteu reagent. Nature Protocols, v. 2, p. 875-877, 2007.

BARROS, H. D. F. Q. et al. Influence of different types of acids and $\mathrm{pH}$ in the recovery of bioactive compounds in Jabuticaba peel (Plinia cauliflora). Food Research International, 124, 16-26, 2019. 
BOLDUC, M-P, et al. Sensitivity of bifidobacteria to oxygen and redox potential in nonfermented pasteurized milk. International Dairy Journal, v. 16, p. 1038-1048, 2006.

COMUNIAN, T. A.; SILVA, M. P.; SOUZA, C. J. F. The use of food by-products as a novel for functional foods: Their use as ingredients and for the encapsulation process. Trends in Food Science \& Technology, v. 108, p. 269-280, 2021.

IBRAHIM, F. et al. Probiotic bacteria as potential detoxification tools: assessing their heavy metal binding isotherms. Canadian Journal of Microbiology, v. 52, p. 877-885, 2006.

FERREIRA, P. R. et al. Beverage based on whey permeate with phenolic extract of jabuticaba peel: A pilot study on effects on muscle and oxidative stress in trained individuals. Journal of Functional Foods, v. 65, 103749, 2020.

THE METABOLOMICS INNOVATION CENTRE. FooDB Version 1.0. 2021. Disponível em: www.foodb.ca. Acesso em: 24 set. 2021.

GUASCH-FERRÉ, M. et al. Dietary Polyphenols, Mediterranean Diet, Prediabetes, and Type 2 Diabetes: A Narrative Review of the Evidence. Oxidative Medicine and Cellular Longevity, 6723931, 2017.

HARRIS, M. F.; LOGAN, J. L. (2014). Determination of log Kow Values for Four Drugs. Journal of Chemical Education, v. 91, p. 915-918, 2014.

HOLKEM, A. T. et al. Sugarcane Juice with Co-encapsulated Bifidobacterium animalis subsp. lactis BLC1 and Proanthocyanidin-Rich Cinnamon Extract. Probiotics and Antimicrobial Proteins, v. 12, p. 1179-1192, 2020.

INADA, K. O. P. et al. Bioaccessibility of phenolic compounds of jaboticaba (Plinia jaboticaba) peel and seed after simulated gastrointestinal digestion and gut microbiota fermentation. Journal of Functional Foods, v. 67, 2020. 
JALALI, M., et al. Stability evaluation of freeze-dried Lactobacillus paracasei subsp. tolerance and Lactobacillus delbrueckii subsp. bulgaricus in oral capsules. Research in pharmaceutical sciences, v. 7, p. 31-36, 2012.

LENQUISTE, S. A. et al. Jaboticaba peel and jaboticaba peel aqueous extract shows in vitro and in vivo antioxidant properties in obesity model. Food Research International, 77, 162-170, 2015.

MA, G.; CHEN, Y. Polyphenol supplementation benefits human health via gut microbiota: A systematic review via meta-analysis. Journal of Functional Foods, v. 66, 103829, 2020.

MACHADO, G. H. A. et al. Antibacterial activity and in vivo wound healing potential of phenolic extracts from jaboticaba skin. Chemical Biology \& Drug Design, v. 92, p. 1333-1343, 2018.

MASSA, N. M. L. et al. Effects of digested jabuticaba (Myrciaria jaboticaba (Vell.) Berg) byproduct on growth and metabolism of Lactobacillus and Bifidobacterium indicate prebiotic properties. LWT - Food Science and Technology, v. 131, 109766, 2020.

MORSCHBACHER, A. P. et al. Assessment of selenium bioaccumulation in lactic acid bacteria. Journal of Dairy Science, v. 101, p. 10626-10635, 2018.

NGUYEN, T-T et al. Encapsulation of Hibiscus sabdariffa L. anthocyanins as natural colours in yeast. Food Research International, v. 107, p. 275-280, 2018.

NELSON, G.; DUCKHAM, S. C.; CROTHERS, M. E. D. Microencapsulation in Yeast Cells and Applications in Drug Delivery. In Polymeric Drug Delivery I. ACS Symposium Series. 923: American Chemical Society, p. 268, 2006.

PARAMERA, E. I.; KONTELES, S. J.; KARATHANOS, V. T. Microencapsulation of curcumin in cells of Saccharomyces cerevisiae. Food Chemistry, v. 125, p. 892-902, 2011 a. 
PARAMERA, E. I.; KONTELES, S. J.; KARATHANOS, V. T. Stability and release properties of curcumin encapsulated in Saccharomyces cerevisiae, $\beta$-cyclodextrin and modified starch. Food Chemistry, v. 125, p. 913-922, 2011 b.

PHAM-HOANG, B. N. et al. Strategies to improve carotene entry into cells of Yarrowia lipolytica in a goal of encapsulation. Journal of Food Engineering, v. 224, p. 88-94, 2018.

PHAM-HOANG, B. N.; VOILLEY, A.; WACHÉ, Y. Molecule structural factors influencing the loading of flavoring compounds in a natural-preformed capsule: Yeast cells. Colloids and Surfaces B: Biointerfaces, v. 148, 2016, p. 220-228, 2016.

PHAN, A. D. T. et al. Binding selectivity of dietary polyphenols to different plant cell wall components: Quantification and mechanism. Food Chemistry, v. 233, p. 216-227, 2017.

PEREIRA, E. P. R. et al. Oxidative stress in probiotic Petit Suisse: Is the jabuticaba skin extract a potential option? Food Research International, v. 81, p. 149-156, 2016.

RAI, R. et al. Infusion of trans-resveratrol in micron-scale grape skin powder for enhanced stability and bioaccessibility. Food Chemistry, v. 340, 127894, 2021.

SANTOS, D. T.; VEGGI, P.C.; MEIRELLES, M. A. A. Extraction of antioxidant compounds from Jabuticaba (Myrciaria cauliflora) skins: Yield, composition and economical evaluation. Journal of Food Engineering, v. 101, p. 23-31, 2010.

SILVA, M. C. et al. Use of the jabuticaba (Myrciaria cauliflora) depulping residueto produce a natural pigment powder with functional properties. LWT - Food Science and Technology, v. 55, p. 203-209, 2014.

SILVA, M. P. et al. Production and characterization of solid lipid microparticles loaded with guaraná (Paullinia cupana) seed extract. Food Research International, v. 123, p. 144-152, 2019. 
SINGLETON, V. L.; ORTHOFER, R.; LAMUELA-RAVENTOS, R. M. Analysis of total phenols and other oxidation substrates and antioxidants by means of Folin-ciocalteu reagent. Methods of Enzymology, v. 299, p. 152-178, 1999.

SIRK, T. W. et al. Molecular binding of catechins to biomembranes: relationship to biological activity. Journal of agricultural and food chemistry, v. 57, p. 6720-6728, 2009.

SOUZA, V. B. et al. Functional properties and encapsulation of a proanthocyanidin-rich cinnamon extract (Cinnamomum zeylanicum) by complex coacervation using gelatin and different polysaccharides. Food Hydrocolloids, v. 77, 297-306, 2018.

TARONE, A. G., et al. Inulin/fructooligosaccharides/pectin-based structured systems: Promising encapsulating matrices of polyphenols recovered from jabuticaba peel. Food Hydrocolloids, v. 111, 106387, 2021.

VALDÉS, L., et al. The relationship between phenolic compounds from diet and microbiota: impact on human health. Food \& Function, v. 6, p.2424-2439, 2015.

WANG, L. et al. A new insight into the adsorption mechanism of patulin by the heat-inactive lactic acid bacteria cells. Food Control, 50, 104-110, 2015.

YOUNG, S.; RAI, R.; NITIN, N. Bioaccessibility of curcumin encapsulated in yeast cells and yeast cell wall particles. Food Chemistry, 309, 125700, 2020.

YOUNG, S.; DEA, S.; NITIN, N. (2017). Vacuum facilitated infusion of bioactives into yeast microcarriers: Evaluation of a novel encapsulation approach. Food Research International, v. 100, p. 100-112, 2017. 
7 CHAPTER 6 - LOADING OF PHENOLIC COMPOUNDS IN PROBIOTIC CELLS IMPROVES THEIR SURVIVABILITY DURING IN VITRO DIGESTION

Short Communication 


\title{
7 CHAPTER 6 - LOADING OF PHENOLIC COMPOUNDS IN PROBIOTIC CELLS IMPROVES THEIR SURVIVABILITY DURING IN VITRO DIGESTION
}

\begin{abstract}
Simultaneous delivery of phenolic compounds (PC) and probiotics may improve the proliferation of probiotics and the absorption of PC and their metabolites in the gut. However, probiotic cells may be sensitive to acid conditions and bile salts, hampering survivability. In this way, this study aimed to evaluate the vacuum biosorption of PC from plant extracts in live probiotic cells as an alternative to improve the viability of probiotics during in vitro digestion tests. In addition, the hydrophobicity of probiotic cells after vacuum biosorption and the metabolic activity of cells was assessed. Vacuum biosorption of polyphenols increased the hydrophobicity of probiotic cells around 3-5-fold. Concerning the in vitro digestion test, control cells, without biosorption of phenolic compounds, showed a reduction around $2 \log$ CFU after the addition of simulated gastric fluid. On the other hand, probiotics loaded with plant extracts or catechin maintained their population. Furthermore, probiotic cells loaded with phenolic compounds were metabolically active even after being subjected to gastric fluid. Thus, this approach eliminated the need for probiotic encapsulation to get a high amount of cells in the gut.
\end{abstract}


Keywords: vacuum biosorption, Lacticaseibacillus, metabolic activity, phenolic compounds, resistance, plant extracts.

\subsection{INTRODUCTION}

Probiotics are defined as live microorganisms that provide health benefits when taken in adequate amounts, such as improving gut and immune systems by balancing gut microbiota (HILL et al., 2014). Lacticaseibacillus casei (LC), Lacticaseibacillus paracasei (LP) and Lacticaseibacillus rhamnosus (LR) are widely applied for the production of functional and fermented. However, one of the challenges about applying probiotics in food or supplements is the probiotic's sensitivity to the harsh conditions that can be used during the processing, storage and digestion (FAVARO-TRINDADE; HEINEMANN; PEDROSO, 2011). In this context, companies have been selecting resistant strains or protecting them by microencapsulation. Among the encapsulation techniques, spray-drying is widely explored for the protection of probiotics. However, the application of mechanical homogenization on the polymeric solution to disperse probiotics cells, the high temperatures during atomization may cause oxidative stress, reducing the

probiotic viability (BROECKX et al., 2016). Thus, less invasive processes should be investigated to improve the survivability of probiotics.

Other technological properties of probiotic cells are explored, such as removing heavy metals and mycotoxins from food and water by adsorption (IBRAHIM et al., 2006; WANG et al., 2015), as well as the bioaccumulation of micronutrients minerals (MORSCHBACHER et al., 2018). Based on the scientific perspective, investigating the potential binding properties of probiotic cells with bioactive compounds is worth it due to the benefits of co-supplementation.

Some studies have evaluated the synergism between probiotics and phenolic compounds that may improve the proliferation of probiotics and the absorption of phenolic compounds in the gut (VALDÉS et al., 2015). In this way, phenolic compounds were classified as plant-based prebiotic due to the evidence that these compounds are biotransformed by the colon microbiota (GIBSON et al., 2017). In addition, polyphenols have important biological properties, such as antioxidant, anticarcinogenic and antimicrobial activities. Conventional sources of phenolic compounds are red wine, cocoa and coffee. However, other plants have been explored, such as guaraná, an Amazonian fruit that its seeds present stimulant effect by the presence of caffeine and recently was identified as a rich-catechin product (YONEKURA et al., 2016). 
Jabuticaba is a dark purple berry found in Brazil, consumed mainly as juice, jam, and ice cream, removing the peel that may cause the astringency sensation. For this reason, jabuticaba peel is a by-product, although most of the bioactive compounds remain in the peel. Several studies have been investigating the potential of jabuticaba peel as a supplement for the fortification of foods. Pereira et al. (2016) verified that jabuticaba peel extract (JPE) simultaneously applied with probiotics in a petit Suisse cheese formulation protected Lactobacillus acidophilus during the processing and storage, but it did not affect the viability of Bifidobacterium lactis. Another study demonstrated that fruit by-product extracts could increase the growth of probiotic cells and their antioxidant activity may extend the health benefits (ALBUQUERQUE et al., 2019). Thus, producing a rich-phenolic extract from jabuticaba peel followed by the association with probiotic cells may be an alternative for simultaneous delivery.

Vacuum biosorption of phenolic compounds in probiotic cells does not require high temperatures and the use of organic solvents, offering a real innovation regarding existing technologies. Furthermore, this combination may influence the probiotic viability, decreasing the oxidative stress of the cell by the biosorption of bioactive compounds. Until this moment, no work verified the protective effect of biosorption of plant extracts in live probiotic cells during in vitro digestion tests. Besides that, this association of probiotic cells and bioactive compounds, like polyphenols, may influence probiotic viability, decreasing the oxidative stress of the cell. In addition, the association of jabuticaba peel extracts and probiotics could have a synergistic effect on the gut.

This study aimed to provide new evidence about the protective effect of biosorption of polyphenols in live probiotic cells on the viability during in vitro digestion. Moreover, the hydrophobicity of probiotic cells was evaluated before and after vacuum biosorption of vegetable extracts. Finally, probiotic cells after simulated gastric fluid (SGF) were assessed regarding the metabolic activity.

\subsection{MATERIAL AND METHODS}

\subsubsection{Materials}

Guaraná seed was donated by Executive Commission of the Rural Economic Recuperation Plan in Cacao (Taperoá, Bahia, Brazil) and jabuticaba peel by Ricaeli (Cabreuva, Sao Paulo, 
Brazil). As probiotic cells were used L. paracasei BGP-1 (Sacco, Brazil), L. casei ATCC 393 and L. rhamnosus GG.

\subsubsection{Methods}

\subsubsection{Production of extracts from jabuticaba peels and guaraná seed}

Guaraná seed extract was produced as suggested by Silva et al. (2019) with some modifications. Dried guaraná seed was added in 25\% ethanol solution in the proportion 1:20 (w:w) and mixed using a mechanical stirring at $60{ }^{\circ} \mathrm{C}$ for $30 \mathrm{~min}$. Similarly, dried jabuticaba peel was mixed with $25 \%$ ethanol solution (v/v) in the proportion $1: 25$ (w:w) at $40{ }^{\circ} \mathrm{C}$ for $2 \mathrm{~h}$. Then, jabuticaba peel extract (JPE) and guaraná seed extract (GSE) were filtered and centrifugated, removing the particles.

\subsubsection{Growth of probiotics in supplemented MRS broth with catechin solutions, jabuticaba and} guaraná extracts

The influence of MRS broth supplementation with plant extracts and catechin solutions in growth of probiotic cells was evaluated using SpectraMax ${ }^{\circledR}$ M5 Multi-Mode Microplate Reader by reading optical density (OD). The microplate was filled with $160 \mu \mathrm{L}$ of MRS broth, $40 \mu \mathrm{L}$ of plant extracts and $20 \mu \mathrm{L}$ of bacterial suspension. As control, $40 \mu \mathrm{L}$ of sterile water was pipetted instead of plant extracts. In addition, the effect of hydrated catechin solutions at concentrations $181.8 \mu \mathrm{g} / \mathrm{mL}, 90.9 \mu \mathrm{g} / \mathrm{mL}$ and $45.5 \mu \mathrm{g} / \mathrm{mL}$ were evaluated. The microplate was incubated at 37 ${ }^{\circ} \mathrm{C}$ and OD measurements $(K=600 \mathrm{~nm})$ were read each hour until complete $24 \mathrm{~h}$.

\subsubsection{Vacuum biosorption of vegetable extracts and catechin solution in live probiotic cells}

Probiotic cells were activated in $10 \mathrm{~mL}$ of MRS broth at $37{ }^{\circ} \mathrm{C}$ for $18 \mathrm{~h}$. Then, cells were added in $100 \mathrm{~mL}$ of MRS broth. Finally, cells were collected by centrifugation and washed twice with sterile PBS buffer.

Vacuum biosorption of polyphenols was carried out using the ratio 1:5 $(\mathrm{w} / \mathrm{w})$ of probiotic cells to plant extracts or catechin solution $(4 \mathrm{mg} / \mathrm{mL})$. Then, the mixtures were treated with $99 \%$ of vacuum for $5 \mathrm{~s}$ (YOUNG et al., 2019). Finally, biosorpted cells were washed three times with PBS buffer, removing the remained extracts. 


\subsubsection{Hydrophobicity of probiotic cells}

Cells before and after the vacuum biosorption were washed twice and resuspended in sterile PBS buffer. The bacterial suspension was adjusted by optical density (OD) at $640 \mathrm{~nm}$ to around 0.8. After, $3.5 \mathrm{~mL}$ of sample was mixed with $0.5 \mathrm{~mL}$ of octan using a vortex for $2 \mathrm{~min}$. The tubes were rested, and phases were separated after $15 \mathrm{~min}$. The aqueous phase was removed and the OD was determined at $640 \mathrm{~nm}$. Cell surface hydrophobicity was calculated as shown in Equation 1.

$$
\text { Hydrophobicity }(\%)=\left[\left(O D_{0}-O D_{F}\right) / O D_{0}\right] \times 100
$$

\subsubsection{Survivability of probiotic cells during in vitro digestion test}

In vitro digestion test was performed according to Minekus et al. (2014) with modification. First, simulated gastric fluid (SGF) and simulated intestinal fluid (SIF) was prepared as detailed by Minekus et al. (2014). Approximately $1 \mathrm{~g}$ of the probiotic pellet was added in $3 \mathrm{~mL}$ of sterile water for dilution. Then, $4 \mathrm{ml}$ of SGF was added to the suspension and $\mathrm{pH}$ was adjusted to 3 using $\mathrm{HCl}(6 \mathrm{M})$ followed by the addition of $0.2 \mathrm{~mL}$ of pepsin solution $(2,000 \mathrm{U} / \mathrm{mL})$. The mixture was incubated in a rotary shaker at $100 \mathrm{rpm} / 37^{\circ} \mathrm{C}$ for $2 \mathrm{~h}$. Sequentially, around $5 \mathrm{ml}$ of SIF was added to the mixture and adjusted $\mathrm{pH}$ to 7 using $\mathrm{NaOH}(1 \mathrm{M})$. Finally, $1 \mathrm{~mL}$ of bile salts $(10 \mathrm{mM})$ and 2 $\mathrm{mL}$ of pancreatin $(100 \mathrm{U} / \mathrm{mL})$ solutions were added to the mixture. Then, samples were incubated until the complete $4 \mathrm{~h}$ of in vitro test.

Aliquots were withdrawn during this assay $(\mathrm{t}=0,1 \mathrm{~h}, 2 \mathrm{~h}, 3 \mathrm{~h}$ and $4 \mathrm{~h})$ for serial dilution and plated onto MRS agar. The control sample (without extract) was carried out as blank.

\subsubsection{Fluorescence assay of metabolic activity of probiotic cells using resazurin}

The reduction of resazurin was evaluated as proposed by Oliveira et al. (2017). After cells were treated with simulated gastric fluid for $2 \mathrm{~h}, 1 \mathrm{~mL}$ of each sample was centrifugated $(16,000$ $\mathrm{xg}$ for $2 \mathrm{~min}$ ) and resuspended in $1 \mathrm{~mL}$ of MRS broth containing $50 \mu \mathrm{M}$ of resazurin. Then, the plate was incubated at $37^{\circ} \mathrm{C}$ for $16 \mathrm{~h}$ and read (Tecan SpectraFluor Plus) each 5 min using a 530 
$\mathrm{nm}$ excitation filter and a $580 \mathrm{~nm}$ emission filter. As a control, cells did not treat with simulated gastric fluid were evaluated.

\subsection{RESULTS AND DISCUSSION}

\subsubsection{Growth of probiotic cells in supplemented MRS broth with plant extracts and catechin}

Figure 23 illustrates the growth curves of probiotics in MRS broth (control) or supplemented MRS broth containing plant extracts or catechin solutions. Catechin solutions enhanced the proliferation of probiotic cells compared with the growth curve of probiotics incubated in MRS broth without supplementation. Among plant extracts, jabuticaba in water and guaraná in ethanol $25 \%$ displayed similar growth curves, while jabuticaba in ethanol $25 \%$ did not promote significant probiotic growth. Thus, catechin was effective in improving the proliferation of these probiotic strains, as reported by Gaudreau et al. (2013). However, the supplementation of the mixture of phenolic compounds from plant extracts in MRS broth could support probiotic growth without a significant rise under aerobic incubation conditions. Another important approach to confirm these results could be the enumeration of probiotics by plate count and evaluating the effect of phenolics in MRS broth on prolonged incubation time.

China et al. (2012) reported that MRS broth supplemented with Sesbania grandiflora flower extract significantly increased the growth of Lactobacillus acidophilus. These authors indicated that the antioxidant effect of the extract could regulate oxidative stress of probiotic cells during the growth. However, it is essential to point out that these authors used DMSO to solubilize freeze-dried extract, which also presents antioxidant action.

Thus, plant extracts and catechin solutions showed potential to combine with probiotic cells, indicating that their vacuum biosorption could benefit probiotics.

\subsubsection{Hydrophobicity of probiotic cells}

The binding properties of cells are related to the hydrophobicity, which added up with the chemical profile of bioactive compounds, mainly coefficient partition (log p), which may indicate the potential of probiotic cells to bind the extract. Table 15 shows the hydrophobicity of probiotic cells before and after vacuum biosorption.

Regarding the hydrophobicity of probiotic cells, values ranged from 5.7 to $16 \%$, even after the vacuum biosorption of $25 \%$ ethanol solution, demonstrating the low hydrophobicity of these 
probiotic strains. However, cells loaded with JP25\% or GSE increased the hydrophobicity, varying from 25 to 40\%, which is around 3-5-fold higher than control cells. Also, probiotic cells loaded with catechin increased the hydrophobicity, excepting the strain $L$. casei. This difference could be explained by the content of proteins in the surface layer and the charge, using proteomics study and zeta potential. Based on these results, vacuum biosorption of phenolic compounds in probiotic cells is a promising option to increase the hydrophobicity of cells, which is desirable to improve the bind in the cell wall gut.

Figure 23 - Growth curves of probiotic cells (A) Lacticaseibacillus paracasei BGP-1, (B) Lacticaseibacillus casei and (C) Lacticaseibacillus rhamnosus GG in control MRS broth (blue line) and MRS broth supplemented with watery jabuticaba peel extract (orange line), hydroalcoholic jabuticaba peel extract (gray line), guaraná seed extract (yellow line), catechin solution at concentrations $181.8 \mu \mathrm{g} / \mathrm{mL}$ (light blue line) $90.9 \mu \mathrm{g} / \mathrm{mL}$ (green line) and $45.4 \mu \mathrm{g} / \mathrm{mL}$ (black line).

(A)

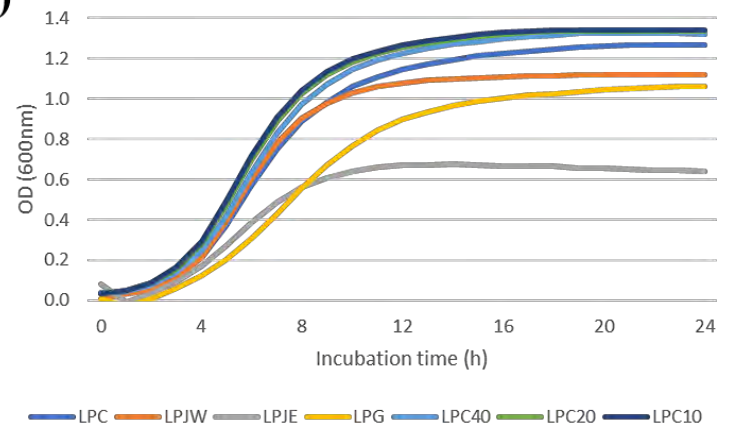

(B)

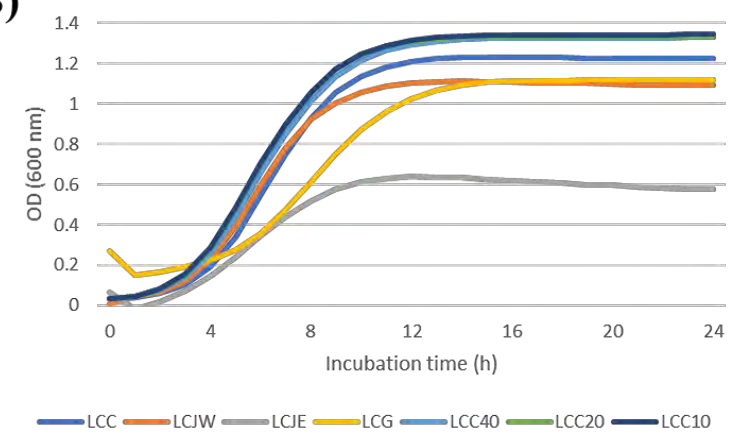

(C)

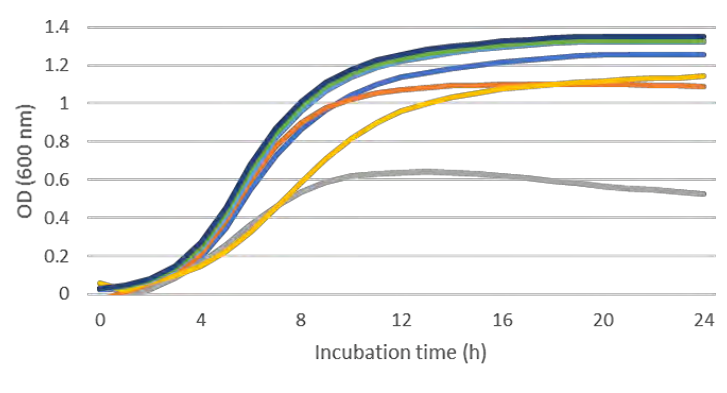

${ }_{\mathrm{LRC}}^{\mathrm{LRJW}} \mathrm{LRJE}_{\mathrm{LRG}}^{\mathrm{LRG}} \mathrm{LRC40}_{\mathrm{LRC20}}^{\mathrm{L}}{ }_{\mathrm{LRC10}}^{\mathrm{L}}$

Reference: Own source.

\subsubsection{Survivability of probiotic cells during in vitro digestion test}

Live probiotic cells must reach the colon alive for colonization and bring health benefits. In this way, Figure 24 displays the survivability of probiotic cells during in vitro digestion test. 
Cells infused with ethanol 25\% (control - white and grey bars) reduced around $2 \log$ CFU after adding SGF, completing $3 \log \mathrm{CFU}$ at the end of the in vitro test. However, probiotic cells loaded with catechin or jabuticaba peel extract $(\mathrm{J} 25 \%)$ maintained their viability after the addition of simulated gastric fluid, as well as the simulated intestinal fluid. Although counts of probiotic cells loaded with GSE were higher $10 \log \mathrm{CFU} / \mathrm{mL}$, only L. paracasei did not differ in its population during in vitro digestion test. Thus, plant extracts may reduce oxidative stress or inhibit enzymatic activities, avoiding probiotics' death. In addition, as previously studied by Silva et al. (2019), GSE is an inhibitor of some enzymes, such as $\alpha$-glucosidase and lipase, that may be correlated with increased survival of probiotics loaded with GSE in simulated gastrointestinal fluids.

Moreover, jabuticaba peel powder exhibited potential prebiotic properties compared with fructooligosaccharides (FOS), depending on the probiotic strain (MASSA et al., 2020). For this reason, the simultaneous delivery of probiotics and polyphenols could protect as much as encapsulation using polymers. However, further studies about other stress conditions are needed to confirm this aspect.

Table 15 - Hydrophobicity of probiotic cells before (first column) and after vacuum biosorption (VB).

\begin{tabular}{cccccc}
\hline Treatments & Cells & $\begin{array}{c}\text { Cells after VB } \\
\text { of } 25 \% \text { ethanol }\end{array}$ & $\begin{array}{c}\text { Cells after VB } \\
\text { of catechin }\end{array}$ & $\begin{array}{c}\text { Cells after VB } \\
\text { of GSE }\end{array}$ & $\begin{array}{c}\text { Cells after VB } \\
\text { of JP25\% }\end{array}$ \\
\hline L. paracasei & $6.8 \pm 2.0^{\mathrm{Bc}}$ & $6.8 \pm 1.7^{\mathrm{ABc}}$ & $24.2 \pm 3.5^{\mathrm{Ab}}$ & $40.3 \pm 2.6^{\mathrm{Aa}}$ & $38.5 \pm 4.1^{\mathrm{Aa}}$ \\
L. casei & $5.7 \pm 1.7^{\mathrm{Bb}}$ & $2.2 \pm 0.2^{\mathrm{Bc}}$ & $4.4 \pm 0.6^{\mathrm{Bb}}$ & $24.5 \pm 1.5^{\mathrm{Ca}}$ & $26.3 \pm 2.3^{\mathrm{Ba}}$ \\
L. rhamnosus & $16.0 \pm 3.1^{\mathrm{Ac}}$ & $9.9 \pm 0.5^{\mathrm{Ad}}$ & $22.1 \pm 4.4^{\mathrm{Ab}}$ & $33.7 \pm 2.3^{\mathrm{Ba}}$ & $29.1 \pm 2.6^{\mathrm{Ba}}$
\end{tabular}

Values with the same upper-case letter in a column and same lower-case letter in a row are not statistically different ( $>>0.05)$. Reference: Own source.

Another study evaluated the survivability of free and co-encapsulated probiotics with cinnamon extract (HOLKEM; FAVARO-TRINDADE, 2020) using the same in vitro digestion assay protocol as this study (MINEKUS et al., 2014). A similar result was noticed for free probiotics, reducing the viability around $4 \log \mathrm{CFU}$ after in vitro digestion test. However, capsules containing probiotics and cinnamon extract provided protection, maintaining the viability of probiotics (HOLKEM; FAVARO-TRINDADE, 2020). It is essential to highlight that our finding eliminates the application of polymers for protecting probiotics during in vitro digestion tests. 
Figure 24 - Survivability of probiotic cells during in vitro digestion test. Cells were added in simulated gastric fluid (SGF) for $2 \mathrm{~h}$, followed by the addition of simulated intestinal fluid (SIF), completing $4 \mathrm{~h}$. In this figure: LC - L. casei, LR - L. rhamnosus, LP - L. paracasei, control - cells loaded with ethanol $25 \%$, catechin -cells loaded with catechin, J25\% - cells loaded with jabuticaba peel extract, GSE - cells loaded with guaraná seed extract (GSE).
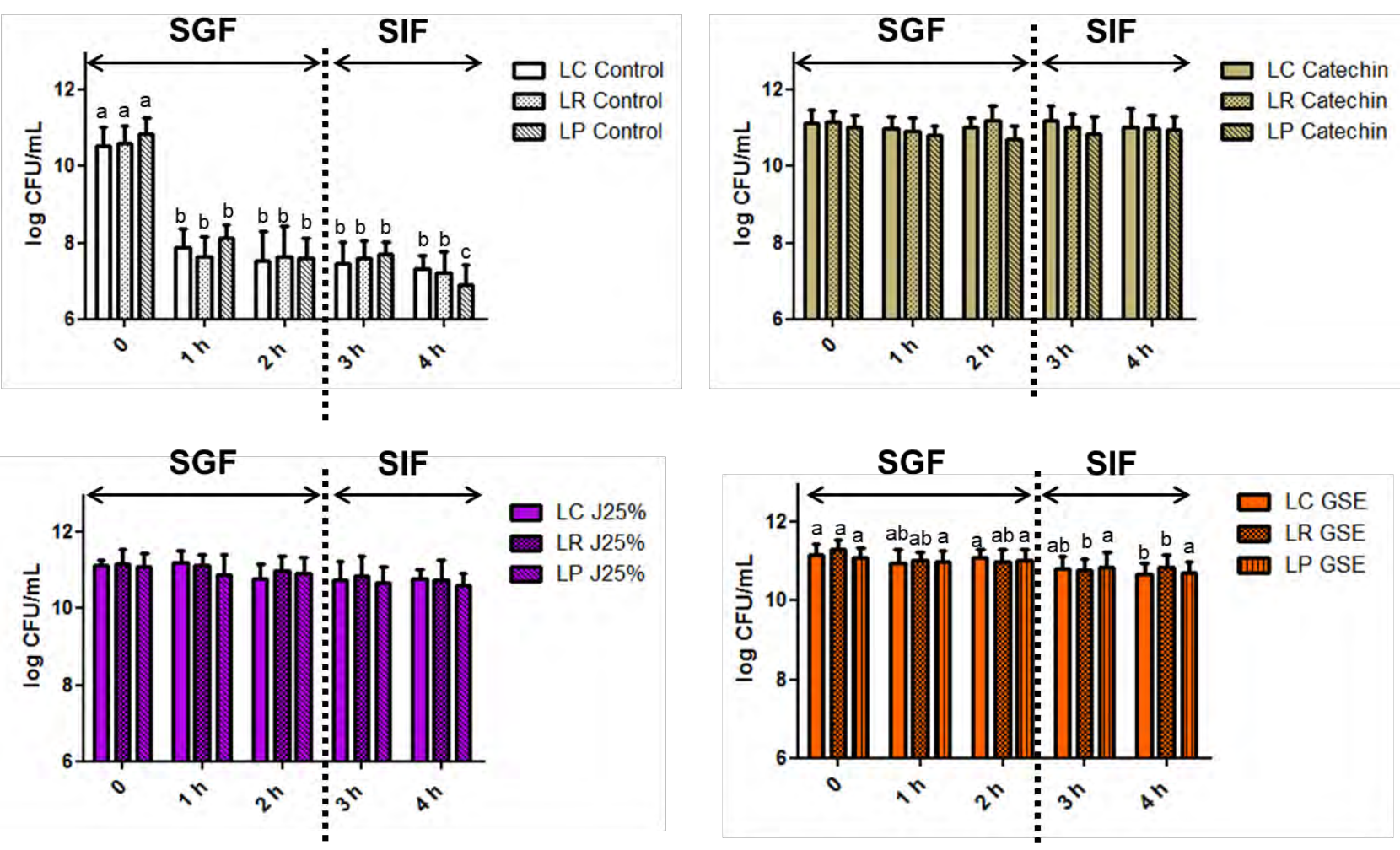

Bars with the same lower-case letter of same treatment are not statistically different $(\mathrm{p}>0.05)$. Reference: Own source.

\subsubsection{Metabolic activity of infused cells after simulated gastric fluid}

The reduction of resazurin to resorufin (fluorescent form) was measured to correlate with the metabolic activity of probiotic cells, as shown in Figure 25. The resorufin production increases the intensity of fluorescence, while the reduction of the peak is related to the production of hydroresorufin (OLIVEIRA et al., 2017).

Maximum fluorescence intensity for control cells (not treated with SGF) was achieved around $1-2 \mathrm{~h}$ of the test, as exhibited in blue lines of graphs displayed in row 1 (Fig. 25). Cells 
treated with SGF for $2 \mathrm{~h}$ showed a delay to get the maximum intensity, which was approximately $8 \mathrm{~h}$ (green and red lines). However, infused cells with plant extracts treated with SGF showed the maximum intensity at the same time required for cells not treated with SGF, as demonstrated in rows 3 and 4 of Figure 25. In this way, these results can be correlated with the loss of cell viability during in vitro digestion test, proving that the biosorption of phenolic compounds improved the survival rate of probiotic cells in SGF.

\subsection{CONCLUSIONS}

Vacuum biosorption of phenolic compounds in live probiotic cells is a potential technique to maintain the viability of probiotics during in vitro digestion tests. The metabolic activity of probiotic cells loaded with plant extracts did not modify after the exposure to the in vitro gastric fluid, whereas the fluorescence intensity of control cells was delayed around 8-10 h. Besides that, biosorption of phenolic compounds increased the hydrophobicity of probiotic cells at least 3-fold, which is important for binding in the intestinal wall for colonization. Further studies should be performed to evaluate the role of single polyphenols and other probiotic strains during this test and correlate with in vivo study.

\section{ACKNOWLEDGEMENTS}

Marluci P. da Silva thanks the São Paulo Research Foundation (FAPESP) for the scholarship awarded (grant \#2016/24895-5 and grant \#2019/09757-3). 
Figure 25 - Metabolic activities of L. casei (LC), L. paracasei (LP) and L. rhamnosus (LR) cells before (blue line) and after the in vitro exposure of gastric fluid without the addition of pepsin (red line) or with pepsin (green line), expressed as fluorescence intensity by time. In this figure: graphs in first row - control cells loaded with ethanol $25 \%$ by vacuum, graphs in second row - cells loaded with catechin solution, graphs in third row cells loaded with guaraná seed extract (GSE) and graphs in fourth row - cells loaded with jabuticaba peel extract (JP25\%).

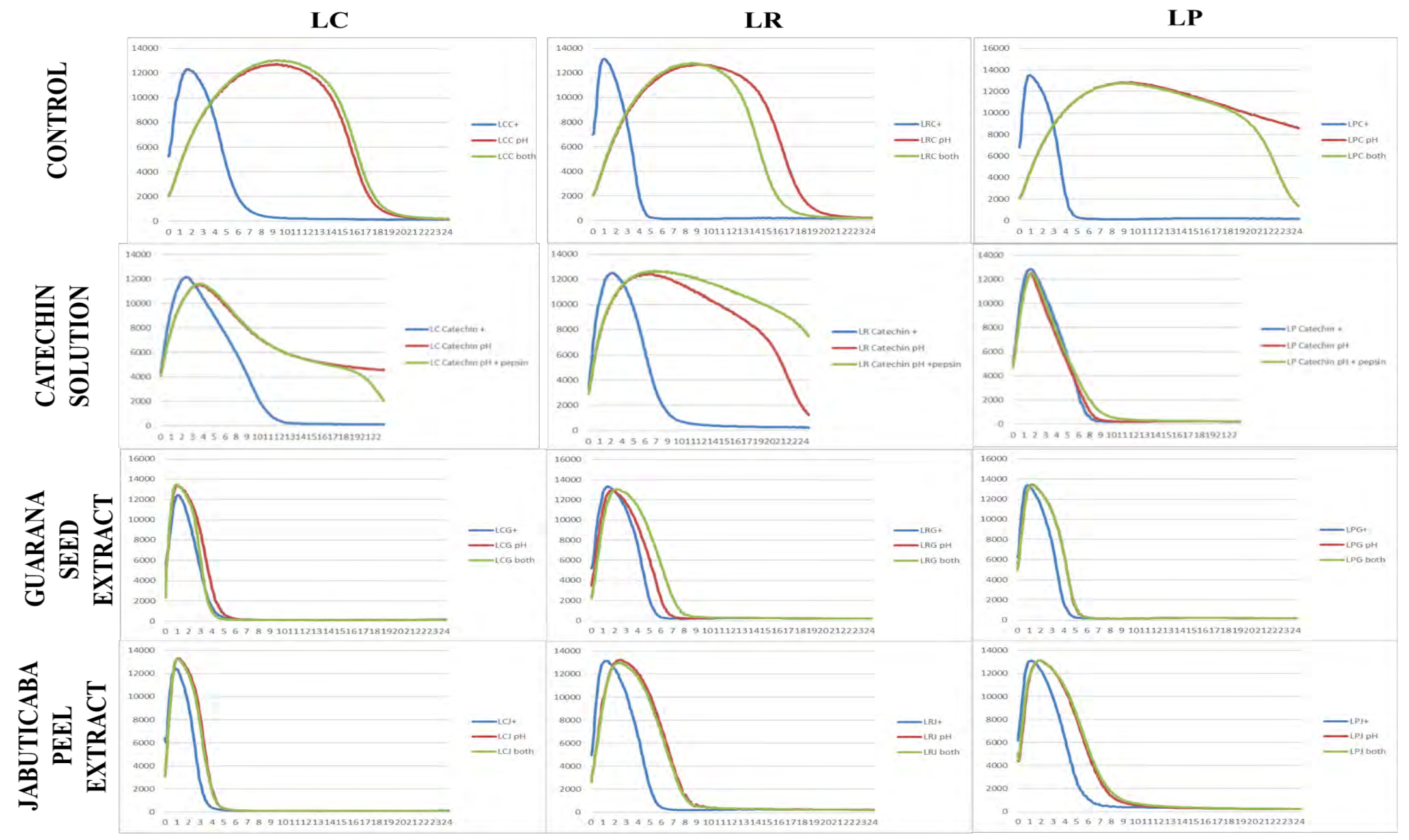

Reference: Own source. 


\section{REFERENCES}

ALBUQUERQUE, M. A. C et al. Tropical fruit by-products water extracts as sources of soluble fibres and phenolic compounds with potential antioxidant, anti-inflammatory, and functional properties. Journal of Functional Foods, v. 52, p. 724-733, 2019.

BROECKX, G. et al. Drying techniques of probiotic bacteria as an important step towards the development of novel pharmabiotics. International Journal of Pharmaceutics, v. 505, p. 303318, 2016.

CHINA, R. et al. Antimicrobial activity of Sesbania grandiflora flower polyphenol extracts on some pathogenic bacteria and growth stimulatory effect on the probiotic organism Lactobacillus acidophilus. Microbiological Research, v. 167, p. 500-506, 2012.

FAVARO-TRINDADE, C. S.; HEINEMANN, R. J. B.; PEDROSO, D. L. Review: Developments in probiotic encapsulation. Perspectives in Agriculture, Veterinary Science, Nutrition and Natural Resources, v.6, p.1-8, 2011.

GIBSON, G. R. et al. The International Scientific Association for Probiotics and Prebiotics (ISAPP) consensus statement on the definition and scope of prebiotics. Nature Reviews Gastroenterology \& Hepatology, v. 14, p. 491-502, 2017.

HILL, C. et al. The International Scientific Association for Probiotics and Prebiotics consensus statement on the scope and appropriate use of the term probiotic. Nature Reviews

Gastroenterology \& Hepatology, v. 11, p. 506-514, 2014.

HOLKEM, A. T.; FAVARO-TRINDADE, C. S. Potential of solid lipid microparticles covered by the protein-polysaccharide complex for protection of probiotics and proanthocyanidin-rich cinnamon extract. Food Research International, v. 136, 109520, 2020.

IBRAHIM, F. et al. Probiotic bacteria as potential detoxification tools: assessing their heavy metal binding isotherms. Canadian Journal of Microbiology, v. 52, n. 9, p. 877-885, 2006.

LEE, J. et al. Determination of Total Monomeric Anthocyanin Pigment Content of Fruit Juices, Beverages, Natural Colorants, and Wines by the $\mathrm{pH}$ Differential Method: collaborative study. Journal of Aoac International, v. 88, p. 1269-1278, 2005. 
MÖRSCHB ÄCHER, A. P. et al. Assessment of selenium bioaccumulation in lactic acid bacteria. Journal of Dairy Science, v. 101, n. 12, p. 10626-10635, 2018.

OLIVEIRA, E. F. et al. Enhanced Antimicrobial Activity Based on a Synergistic Combination of Sublethal Levels of Stresses Induced by UV-A Light and Organic Acids. Applied and Environmental Microbiology, v. 83, p. 1-14, 2017.

PEREIRA, E. P. R. et al. Oxidative stress in probiotic Petit Suisse: is the jabuticaba skin extract a potential option?. Food Research International, v. 81, p. 149-156, 2016.

VALDÉS, L., et al. The relationship between phenolic compounds from diet and microbiota: impact on human health. Food \& Function, v. 6, p.2424-2439, 2015.

YONEKURA, L. et al. Bioavailability of catechins from guaraná (Paullinia cupana) and its effect on antioxidant enzymes and other oxidative stress markers in healthy human subjects. Food \& Function, v. 7, p. 2970-2978.

YOUNG, S.; DEA, S.; NITIN, N. Vacuum facilitated infusion of bioactives into yeast microcarriers: Evaluation of a novel encapsulation approach. Food Research International, v. 100, p. 100-112, 2017.

\section{CONCLUSIONS}


Guaraná seed (GSE) and guaraná peel (GPE) extracts showed antioxidant and prebiotic potential, which are biological properties that value this Amazonian fruit. Both extracts were coencapsulated with probiotics by complex coacervation, providing higher viability of probiotics in simulated gastrointestinal fluids (SGF) and storage. Concerning the release of carotenoids from GPE in SGF, the accumulative release was around 90\%, mainly after the addition of simulated intestinal fluid. In contrast, around $60 \%$ of phenolics from GSE were early released in simulated gastric fluid. However, complex coacervation demonstrated its potential to protect water-soluble core materials since phenolic retention was $88 \%$ and probiotic viability was maintained during storage at $7{ }^{\circ} \mathrm{C}$ for 60 days.

Microcapsules loaded with probiotic and GSE were incorporated in yogurt, avoiding the post-fermentation, and masking the bitter taste of plant extract. Although some food matrices can protect free probiotics without microencapsulation, as evaluated for peanut butter, this technology was efficient to increase the probiotic viability. In addition, the incorporation of microparticles in food matrices may contribute to the fortification and standardization of food processing, generating new functional foods for consumers.

The vacuum biosorption of plant extracts in probiotic cells emerges as a novel technology to enhance probiotic viability in SGF and simultaneously deliver phenolic compounds and probiotics in the gut. Further studies about the affinity of specific phenolics with the probiotic cell wall may fill this gap and the effect of incorporating this delivery system in the food matrix.

Overall, microparticles obtained by complex coacervation and probiotic cells loaded with phenolic-rich plant extracts by vacuum biosorption are promising delivery systems as novel functional ingredients, which may confer health benefits. 


\section{ATTACHMENT A - ACCEPTANCE OF THE RESEARCH ETHIC COMMITTEE FOR THE SENSORY ANALYSIS OF YOGHURT DRINKS AND PEANUT BUTTER}

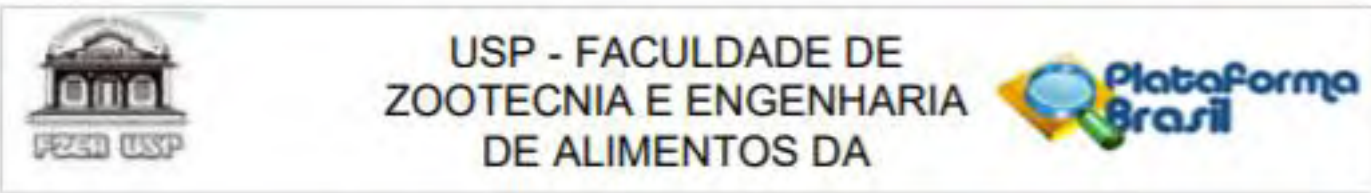

\section{PARECER CONSUBSTANCIADO DO CEP}

\section{DADOS DO PROJETO DE PESQUISA}

Titulo da Pesquisa: Avaliaçăo sensorial de iogurte e pasta de amendoim adicionados de probióticos e extratos do guaraná na forma livre e encapsulada

Pesquisador: Marluci Palazzolli da Silva

Área Temática:

Versăo: 2

CAAE: 13426019.0 .0000 .5422

Instituiçăo Proponente: Faculdade de Zootecnia e Engenharia de Alimentos da USP

Patrocinador Principal: Financiamento Próprio

\section{DADOS DO PARECER}

Número do Parecer: $3.401,420$

\section{Apresentaçăo do Projeto:}

O projeto está alinhado a uma crescente demanda por alimentos saudáveis e funcionais. Propôe a adiçăo de bioativos (extrato de guaraná) e probióticos ao iogurte e pasta de amendoim, produtos bastante consumidos por pessoas de diversas faixas etárias. Como hipotese tem-se que a encapsulaçăo do extrato de guaraná pode influenciar as propriedades sensoriais dos produtos.

\section{Objetivo da Pesquisa:}

Os objetivos envolvem a avaliaçăo da encapsulaçăo sobre caracteristicas sensoriais do iogurte e pasta de amendoim. Para tanto, a análise sensorial será realizada em đuas etapas, cada uma com 120 participantes que avaliarâo 4 amostras e duração de aproximadamente 10 minutos. Uma etapa envolverá a avaliaçào de iogurte acrescido de probióticos e extrato de guaraná nas formas livre e encapsulada. Na outra etapa, será realizada a avaliaçăo da pasta de amendoim com probióticos e extrato de guaraná nas formas livre e encapsulada.

\section{Avaliaçăo dos Riscos e Beneficios:}

A pesquisa năo trará beneficios aos participantes. Foram descritos riscos de desconforto ao provar um produto com gosto potencialmente amargo e riscos com o desenvolvimento de alergias ao amendoim ou a outros ingredientes dos produtos. Além disso, foi mencionado que há riscos mínimos de intoxicaçăo ou desconforto equivalente ao consumo dos produtos.

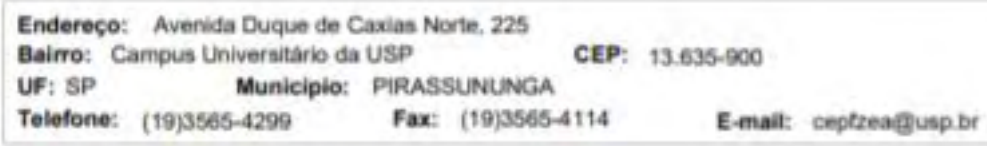




\section{USP - FACULDADE DE ZOOTECNIA E ENGENHARIA DE ALIMENTOS DA}

Contrusçalo do Parecer: 3.401 .420

\section{Comentários e Consideraçōes sobre a Pesquisa:}

O projeto de pesquisa foi apresentado de maneira bastante clara e objetiva.

\section{Consideraçóes sobre os Termos de apresentaçăo obrigatória:}

Foram apresentados dois TCLE, um referente a etapa de análise sensorial do iogurte e outro para a etapa de análise sensorial da pasta de amendoim. Ambos TCLEs atenderam as recomendaçōes e encontravamse dentro das normas.

\section{Recomendaçóes:}

Recomenda-se a aprovação do projeto.

Conclusōes ou Pendências e Lista de Inadequaçōes:

Aprovaçăo do projeto.

Consideraçōes Finais a critério do CEP:

Este CEPH FZEA aprova o desenvolvimento do projeto, a partir desta data.

Este parecer foi elaborado baseado nos documentos abaixo relacionados:

\begin{tabular}{|c|c|c|c|c|}
\hline Tipo Documento & Arquivo & Postagem & Autor & Situação \\
\hline $\begin{array}{l}\text { Informaçōes Básicas } \\
\text { do Projeto }\end{array}$ & $\begin{array}{l}\text { PB_INFORMACCOES_BASICAS_DO_P } \\
\text { ROJETO 1339835.pdt }\end{array}$ & $\begin{array}{c}27 / 05 / 2019 \\
12: 20: 45 \\
\end{array}$ & & Aceito \\
\hline $\begin{array}{l}\text { Projeto Detalhado / } \\
\text { Brochura } \\
\text { Investigador }\end{array}$ & $\begin{array}{l}\text { Projeto_Sensorial_logurte_Pasta_de_a } \\
\text { mendoim_modificado.pdf }\end{array}$ & $\begin{array}{c}27 / 05 / 2019 \\
12: 19: 40\end{array}$ & $\begin{array}{l}\text { Marfuci Palazzoli da } \\
\text { Silva }\end{array}$ & Aceito \\
\hline $\begin{array}{l}\text { TCLE / Termos de } \\
\text { Assentimento / } \\
\text { Justificativa de } \\
\text { Ausência } \\
\end{array}$ & $\begin{array}{l}\text { Termos_de_consentimento_livre_e_escl } \\
\text { arecido.docx }\end{array}$ & $\begin{array}{c}27 / 05 / 2019 \\
12: 17: 26\end{array}$ & $\begin{array}{l}\text { Marluci Palazzoli da } \\
\text { Silva }\end{array}$ & Aceito \\
\hline Cronograma & Cronograma.docx & $\begin{array}{c}27 / 05 / 2019 \\
12: 14: 57\end{array}$ & $\begin{array}{l}\text { Marluci Palazzolii da } \\
\text { Silva }\end{array}$ & Aceito \\
\hline Folha de Rosto & FolhaDeRostoAssinada.pdf & $\begin{array}{c}25 / 04 / 2019 \\
16: 45: 46\end{array}$ & $\begin{array}{l}\text { Marfuci Palazzolli da } \\
\text { Silva }\end{array}$ & Aceito \\
\hline
\end{tabular}

\section{Situação do Parecer:}

Aprovado

Necessita Apreciaçăo da CONEP:

Năo

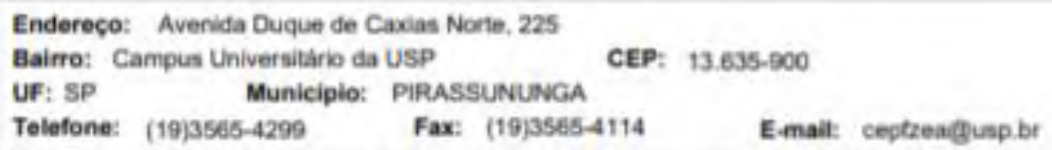




\section{ATTACHMENT B - PAPER PUBLISHED IN “INTERNATIONAL DAIRY JOURNAL”}

Enrichment of yoghurt drink with microcapsules loaded with Lacticaseibacillus paracasei BGP-1
and guaraná seed extract
Author:
Marluci Palazzolli da Silva,Mércia da Silva Mesquita,Fernanda Thaís Vieira Rubio.Marcelo Thomazini,Carmen Sílvia Favaro-Trindade
Publication: International Dairy Journal
Publisher: Elsevier
Date: Available online 4 October 2021
O 2021 Elsevier Ltd. All rights reserved.

Journal Author Rights

Please note that, as the author of this Elsevier article, you retain the right to include it in a thesis or dissertation, provided it is not published commercially. Permission is not required, but please ensure that you reference the journal as the original source. For more information on this and on your other retained rights, please visit: https://Www.elsevier.com/about/our-business/policies/copyright\#Author-rights 
ATTACHMENT C - PAPERS PUBLISHED IN COLLABORATION DURING THIS PERIOD

1. PINHO, L.S. et al. Guaraná (Paullinia cupana) by-product as a source of bioactive compounds and as a natural antioxidant for food applications. Journal of Food Processing and Preservation, v. 45, p. 15854, 2021

2. SANTOS, P.D.F. et al. MICROENCAPSULATION OF CAROTENOID-RICH MATERIALS: A REVIEW. Food Research International, p. 110571, 2021.

3. COMUNIAN, T.A.; SILVA, M. P.; SOUZA, C.J.F. The use of food by-products as a novel for functional foods: Their use as ingredients and for the encapsulation process. Trends in Food Science \& Technology, v. 108, p. 269-280, 2021.

4. COMUNIAN, T.A. et al. Reducing carotenoid loss during storage by co-encapsulation of pequi and buriti oils in oil-in-water emulsions followed by freeze-drying: Use of heated and unheated whey protein isolates as emulsifiers. Food Research International, v. 130, p. $108901,2020$.

5. FAVARO-TRINDADE, C.S. et al. Microencapsulation as a tool to producing an extruded functional food. LWT-Food Science and Technology, v. 128, p. 109433, 2020.

6. RUBIO, F.T.V. et al. Utilization of grape pomaces and brewery waste Saccharomyces cerevisiae for the production of bio-based microencapsulated pigments. Food Research International, v. 136, p. 109470, 2020.

7. MATOS-JR, F.E. et al. Evaluation of the viability and the preservation of the functionality of microencapsulated Lactobacillus paracasei BGP1 and Lactobacillus rhamnosus 64 in lipid particles coated by polymer electrostatic interaction. Journal of Functional Foods, v. 54, p. 98-108, 2019.

8. HOLKEM, A.T. et al. Sugarcane Juice with Co-encapsulated Bifidobacterium animalis subsp. lactis BLC1 and Proanthocyanidin-Rich Cinnamon Extract. Probiotics and Antimicrobial Proteins, 2019.

9. DA SILVA, M.P. et al. Production and characterization of solid lipid microparticles loaded with guaraná (Paullinia cupana) seed extract. Food Research International, v. 123, p. 144-152, 2019.

10. LIMA, P.M. et al. Nutritional Value and Modelling of Carotenoids Extraction from Pumpkin (Cucurbita Moschata) Peel Flour By-Product. International Journal of Food Engineering, v. X, p. X, 2019. 